\title{
UC-NRLF
}

QE

754

||||||||||||||||||||||||||||||||||||||||||||||||||||||||

.W44

कc 45033

1889

v. 3

pt.2-3 



$$
\text { JoLS1 }
$$

\section{PALAONTOGRAPHICAL SOCIETY.}

INS'IITU'TEI MDCCCXLVII.

VOLUME FOR 1897.

L O N D N :

MDccoxevir. 
Digitized by the Internet Archive in 2007 with funding from Microsoft Corporation 


\section{A MONOGRAPH}

OF THE

DEVONIAN FAUNA

OF THE

\section{SOUTH OF ENGLAND.}

BI

G. F. WHIDBORNE, M.A., F.G.S.

$$
\text { Vol. III.-Part II. }
$$

THE FAUNA OF THE MARWOOD AND PILTON BEDS

OF

NORTH DEVON AND SOMERSET

(continued).

Pages 113-178; Plates XVII-XXI.

L O N O N :

PRINTED FOR THE PALAONTOGRAPHICAL SOCIETY.

1897. 

It closely resembles $P$. pygmæus, Whiteaves, which seems to be equally variable in shape, but it is still smaller, being only about $4 \mathrm{~mm}$. instead of $10 \mathrm{~mm}$. in length. Whiteaves compares his shell with Macrodon parvus, White and Whitfield. ${ }^{1}$

Affinities.-Our species approaches Macrodon Hamiltoniæ, Hall, in shape, but is a minute instead of being a rather large shell.

Macrodus venustus, Stein., ${ }^{3}$ as given by Beushausen, ${ }^{4}$ seems much the same shape, but is very much larger and apparently more trigonal.

\section{Parallelodon priscus, Goldfuss, sp.? Plate XII, fig. 6 .}

1834-40. ArCa Prisca, Goldfuss. Petref. Germ., vol. ii, p. 283, pl. clx, fig. 10.

Description.-Left valve rather small, slightly oblique, very convex, very transverse. Hinge-line as long as the shell, broad behind, where it has several long thin linear horizontal teeth. Umbo very prominent, incurved, tending forward and situated at or about the anterior fourth of the length. Anterior margin broad, slightly convex and oblique, meeting the hinge-line at a somewhat acute angle. Inferior margin very long, nearly straight and direct. Postero-inferiol corner slightly produced, rounded. Posterior margin slightly convex and oblique, meeting the hinge at a slightly obtuse angle. Contour of back vertically very convex, horizontally flattened but becoming concave in the supero-lateral parts; with an obtuse ridge or angle running from the umbo to the postero-inferior corner, before which there seems to be a slight dorsal compression. Surface with strong concentric growth-ridges ; finer ornament unknown.

Size.-Height $8 \mathrm{~mm}$., length $17 \mathrm{~mm}$., depth of one valve $3 \mathrm{~mm}$.

Locality.-One specimen is in my Collection from Ironpost, near Dulverton.

Remarks.-The only specimen of this shell being a cast with very slight indications of the ornament, it is impossible fully to identify it. All that can be said is that it seems to be exactly like the equally imperfect specimen described by Goldfuss.

Affinities.-Arca Michelini, d'Archiac and de Verneuil, ${ }^{5}$ appears to have a straighter, less oblique front margin, and a stronger dorsal constriction.

1 1862, White and Whitfield, 'Proc. Boston Soc. Nat. Hist.,' vol. viii, p. 299 (Lower Carb.).

2 1885, Hall, ' Pal. N. Y.,' vol. v, pt. 2, p. 349, pl. li, figs. 1-7, 10, 11.

s 1853, Steininger, 'Geol. Besch. Eifel,' p. 49, pl. ii, fig. 7.

4 1895, Beushausen, 'Abhandl. k. Preuss. Geol. Landes.,' n. f., pt. 17, p.39, pl. iv, figs. 3, t.

5 1842, de Archiac and de Verneuil, 'Geol. Trans.,' ser. 2, vol. vi, pt. 2, p. 373, pl. xxxvi, fig. 6. 
3. Order-ANISOMYARIA, Neumayr, 1883.

I. Family-Modiolopside, Fischer, 1887.

1. Genus-Modiolopsis, Hall, 1847.

1. Modiolopsis, sp. Plate XII, fig. 7.

Size.-Length $13 \mathrm{~mm}$.

Locality.-One specimen from Baggy Point, South Cave, is in the Museum of Practical Geology.

Remarlis. - The specimen here noted is too much obscured by matrix for description, but it appears to belong to this genus, and to be the only evidence of it at present forthcoming from these beds.

It is a long low shell with a very anterior umbo, from which a rather strong angle runs to the postero-inferior corner. The base seems long and straight, and the posterior end short and truncate.

II. Family-MrтiLide, Fleming, 1828.

1. Gerus-Modioli, Lamarck, 1801.

1. Modiola? amygdalina, Phillips. Plate XIII, fig. 12.

1841. Monrola amrgdalina, Phillips. Pal. Foss., p. 38, pl. xvii, figs. $62 a-c$.

Description.-Shell small, narrow, oblique, very convex. Hinge-line probably rather short. Umbo large, rounded, prominent, incurved over the hinge-margin, and facing forwards. Anterior side produced, small, very convex. Anteroinferior side very long, straight. Postero-inferior corner large, produced, roundly convex. Posterior side oblique, convex. Contour convex confluently with umbo, becoming concave on the small, undefined rounded wings. Surface with strong growth-lines (not shown in the figure).

Size.-Height $14 \mathrm{~mm}$., width $11 \mathrm{~mm}$.

Locality. - One specimen in the Porter Collection is from Fremington.

Remarls. - This small shell, which is only a cast, is too indistinct for very certain identification. Its most characteristic feature seems the way in which the anterior end is produced just under the hinge, forming above a kind of lunule in front of the umbo, and bounded below by a slight constriction from the umbo, 
which perhaps would render the margin a little concave if it were better displayed. In this point it reminds one of the genera Modiola and Cypricardinia.

Comparing it with the M. amygdalina of Phillips, it seems to me to agree remarkably with his description, and on placing it in the oblique positions in which his shell seems to be drawn, it assumes exactly the same form as his figure; in fact the shape of his drawings can only be explained by an anterior contour such as exists in our shell.

It is true that his figure shows much stronger growth-lines, but there is some evidence of this in our shell, considering that it is in the nature of a cast.

Affinities.-Avicula pusilla, Barrande, ${ }^{1}$ a much smaller and extremely variable shell, occasionally approaches it in shape.

\section{Genus-Spa'thelia, Hall, 1885.}

"Shell equivalve, very inequilateral, wider behind; anterior end short, narrowly rounded; beaks subanterior, small; umbonal slope rounded or subangular; surface with concentric striæ, sometimes lamellose; probably related to the Lithophagi."

The above are the characters given by Hall; and if, as seems from them and his figures, the following species belongs to it, it may be added that there seems to be an external ligament, a large oval muscle-scar situated in the centre of the anterior end, and a larger circular posterior muscle-scar situated on the upper part of the shell near the posterior end. Along the posterior hinge-line the surface seems concave, bearing two linear transverse ridges, but it does not appear whether they form part of the hinge.

\section{Spathella munda, n. sp. Plate IX, figs. 1, $1 a$; and Plate XI, figs. 1, 2.}

Description.-Shell moderate in size, convex, very oblique and transverse. Hinge-margin very slightly curved, considerably less than the length of the shell, bearing one or two long, linear, horizontal ridges, which seem to bend beneath the umbo with hardly any break. Anterior margin very narrow and doubly convex, almost subangular in front. Inferior margin very long, oblique and nearly straight. Posterior margin very broad, semicircular below, becoming straight and oblique above as it merges into the hinge-margin. Umbo low, wide, flattened, proximate, slightly elevated above the hinge-line, tending forward and

1 1881, Barrande, 'Syst. Sil. Bohême,' vol. vi, pl. cev, figs. 1-22, Et. F, G. 
situated at the anterior seventh of the length. Contour gently convex, becoming transversely flat or slightly concave on the back, and sometimes with a slight post-umbonal ridge which vanishes before reaching the postero-inferior corner. Surface with thirty or forty flat, step-like, regular ridges, possibly lamellar, narrow and divaricating in front, becoming gradually larger behind, and indistinct and confused in the postero-superior region, which seems bounded above by a rounded ridge or convexity close to the margin. Cast marked on and near the umbo with regular rows of numerous small rounded tubercles (indicating pits on the inner surface of shell). Anterior muscle-scar apparently shallow, oval, large, situated in the centre of the anterior end; posterior scar larger, situated near the upper part of the posterior end. Umbo in cast preceded by a shallow concave sulcus, running halfway down. Lunule biconcave, undefined. Shell-structure very thin.

Size.-Height $16 \mathrm{~mm}$., length $35 \mathrm{~mm}$., depth of one valve $5 \mathrm{~mm}$.

Localities.-In the Porter Collection is one specimen (cast and mould) from Fremington; and in my Collection four specimens from Frankmarch.

Remarks.-The Fremington specimen is larger and longer than the others, and does not show the pittings, sulcus, and post-umbonal ridge seen in the latter. It seems, however, probable that they all belong to one species, and that the differences are due to their state of preservation. The character of the hinge seems peculiar and difficult to interpret in the different specimens.

Affinities.-It closely resembles the two species of Spathella described by Hall, ${ }^{1}$ but differs in its more regular ornament, less cylindrical form, and narrower and longer anterior end. It seems to bear the resemblance to Lithophagi indicated by Hall.

Pullastra modiolaris, F. A. Römer, ${ }^{2}$ is flatter, with a shorter anterior end, añd smaller, less defined umbo.

\section{Genus-Digoniomya (Provisional genus).}

Shell very inequilateral, angular, transversely rhomboidal, acute behind. Hinge long, straight, thickened. Back depressed centrally, with rounded ridges running from the umbo to the anterior and posterior ends of the base, posteriorly oblique and flattened. Ligament external, situated in a long groove (?). Umbo acute, proximate.

This provisional genus is suggested with the greatest hesitation on account of the extreme poverty of the material; but it seems to be the only course open, as

1 1885, Hall, 'Pal. N. Y.,' vol. v, pt. 1, No. 2, pp. 407, 408, pl. lxvi, figs. 36-42.

2 1850, F. A. Römer, 'Beitr. Harzgeb.' pt. 1, p. 60, pl. ix, figs. 21 a, b. 
I have been quite unable to find any genus in which there appears to be the slightest ground for placing the following species.

1. Digoniomya elegans. Plate XIII, fig. 13.

Description.-Left valve large, oblique, lozenge-shaped, very transverse, convex. Umbo small, very sharp, oblique, incurved, and prominent, situate very anteriorly, being only about one-tenth of the length of the shell from the anterior side, and excavated along its back by a concave depression which is continued to the middle of the hind margin. Hinge-line about two-thirds the length of shell, straight. Anterior margin very narrow, subangular. Inferior margin very long and slightly sigmoid, being a little concave towards the rear. Postero-inferior corner very much produced, narrow, and so sharply rounded as to be almost subangular. Posterior side very oblique, long, nearly straight. Contour of surface very convex vertically; the front and back of the umbo being continued in low rounded prominences to the antero-inferior and postero-inferior corners, between and behind which the shell is slightly concave. Surface apparently covered with a few irregular growth-lines.

Size.-Length $60 \mathrm{~mm}$., height $20 \mathrm{~mm}$., depth of one valve $10 \mathrm{~mm}$.

Localities.-In the Musenm of Practical Geology is a specimen from Croyde.

Remarles. - I have been unable to refer this shell to any known genus. While remarkable in form, its state of preservation is not such as to give full information as to its nature.

III. Family-AvIOdLIDe, d'Orbigny, 1843.

I. Sub-family-AмвоNYohine, Miller.

1. Genus-MY'TLaRda, Hall, 1870.

The following species is provisionally placed under this genus solely on account of its general shape, and probably may have to be transferred elsewhere should clearer specimens be found.

1. Mytllarca? modioloides, n.sp. Plate XIII, fig. 8.

Description.-Left valve of moderate size, very oblique, subtriangular, convex. Anterior side very narrow and convex. Umbo apparently situated at or close to 
the anterior point, rounded, proximate. Hinge-margin straight, about two-thirds the length of shell. Margin running from beneath the umbo in a long, oblique, straight or slightly flexuous line to the postero-inferior corner, which it rounds in a broad parabolic sweep, and is continued back obliquely in a gentle convex line to the rear of the hinge-margin. Greatest depth of shell near the umbo, and line of greatest depth running from the umbo close to the front margins. Contour of surface almost perpendicular on the antero-inferior slope, very convex on the back, and gradually becoming slightly concave near the postero-superior corner, so as to form a small undefined wing.

Size.-About $15 \mathrm{~mm}$. long by $12 \mathrm{~mm}$. high.

Locality.-One specimen from Braunton is in the Museum of Practical Geology.

Remarls. - The fossil above described is rendered rather obscure by the encroachment of the matrix over its margins, but it evidently is of a very typical mytiloid shape, and appears to be definitely unlike any other palæozoic species.

Affinities.-Cardiomorpha mytiloides, F. A. Römer, ${ }^{1}$ seems to be a steeper and differently shaped shell.

Modiomorpha submissa, Barrande, ${ }^{2}$ sp., as given by Barrois, ${ }^{3}$ seems more transverse, and has a narrower umbo and more dilate front side.

Among other points the obliquity of the posterior side distinguishes it from Leptodesna citimum.

Mytilarca inflata, Whiteaves, ${ }^{4}$ is somerwat like in shape and in the bluntness of the umbo, but is shorter and more convex.

Mytilus sabesianus, de Ryckholt, ${ }^{5}$ appears to be shorter and more regularly ovate, with a sharper umbo, and a shorter and more concave antero-inferior margin. Isocardia contorta, Barrande, ${ }^{6}$ may also be compared.

\section{Sub-family-Ariculine, Stoliczlea, 1871.}

1. Genus-Cobracephalus (Provisional genus).

Shell inequivalve, inequilateral, oblique, with large front wing and dilate hind wing. Umbo extending above the long straight hinge-line, arching forward and, in the right valve, overhanging. Contour divided by five or six radiating angles, spreading from the umbo or its neighbourhood to the margins. Surface marked by crowded squared growth-lines.

1 1860, F. A. Römer, 'Beitr. Harzgeb.,' pt. 4, p. 163, pl. xхv, fig. 14.

2 1881, Barrande, ·Syst. Sil. Bohême,' vol. vi, pl. cclviii, figs. 4, 1-7, Et. F.

s 1889, Barrois, 'Mém. Soc. Géol. Nord,' vol. iii, p. 170, pl. xii, figs. $2-2$ c.

4 1891, Whiteaves, 'Cont. Canad. Pal.,' vol. i, pt. 4, p. 293, pl. xxxviii, figs. 5-6a.

5 1851, de Ryckholt, 'Mélang. Paléont.,' pt. 2, p. 85, pl. xvi, figs. 22, 23.

6 1881, Barrande, 'S Sys. Sil. Bohême,' vol, vi, pl. celx, figs. 1, 1-14, Et. E. 
This suggested genus appears to approach Cassianella in shape, but is more oblique, and the right valve is deeply convex, while probably the other valve is much flatter. Many points must for the present remain undefined, and the genus must therefore be regarded as entirely provisional. It seems, however, to be essentially aviculoid. Its angularity of contour reminds us of Conocarilium, but it has a definite wing in place of the tubular projection of that genus.

\section{Cobraciphalus angulosus, n. sp. Plate XIII, figs. $9,9 a$.}

Description.-Shell small, convex, angulated, very transverse and oblique. Umbo prominent, elevated but flattened, much incurved, arching forward, acute, situated at or about the anterior third of the length, and apparently extending slightly above the hinge-line. Hinge-line equal to the greatest length of shell. Contour of surface vertically convex; horizontally angulated; being (1) flat on a narrow area bounded by rounded angles, which run from the umbo obliquely backward to inferior margin; (2) in front of this, deeply perpendicular, then oblique at the base of front wing, then flat on front wing, and lastly sigmoid at the antero-superior corner; (3) behind the central band, first perpendicular, then oblique, then angulated by a line from behind umbo to the postero-inferior corner, and then oblique and concave, forming a broad hind wing. Anterior wing large, trapezoidal, pointed in front, bounded by an angulated margin. Anterior margin apparently nearly perpendicular below the wing. Inferior margin very short and straight. Posterior margin oblique, convex, angulated. Surface covered by very numerous and crowded, parallel but unequal, sharp, elevated, concentric threads or striæ, separated by deep concavities, which are rather wider than the threads, and crossed by numerous indistinct radiations.

Size.-Height $10 \mathrm{~mm}$., length $14 \mathrm{~mm}$., depth $2.5 \mathrm{~mm}$.

Localities.-There is a single specimen from Top Orchard in the Woodwardian Museum.

Remartss.-I have only seen a single valve of this strange shell.

\section{Genus-Leptodesma, Hall, 1883.}

The distinguishing mark of this genus, as compared with Leiopteria, is its nasute, angulated front wing. It also appears more oblique in general shape, the anterior margin being less protruded. Though some species seem difficult to assign, the two genera appear on the whole to be well characterised. 
1. Leptodesma citimum, ${ }^{1}$ n. sp. Plate XIII, figs. $7,7 \mathrm{a}$.

Description.-Shell inequivalve. Left valve large, oblique, subtriangular, rather transverse, moderately convex. Umbo small, elevated, oblique, proximate, arching forward, overhanging the hinge-margin, apically acute, and situate at about one-fifth the length of the shell from its anterior end. Hinge-margin long, straight, equal to the greatest length of the shell. Anterior wing rather large, nasute in front, vertically convex, horizontally sloping, bounded by an oblique linear depression, which reaches the margin rather more than halfway down. Front cardinal angle between $60^{\circ}$ and $90^{\circ}$. Anterior margin oblique, convex on the higher part of the wing, then slightly concave to the end of the wing, and then slightly convex as it passes into the short inferior margin. Posteroinferior corner broadly and deeply convex. Posterior margin slightly oblique, straight above, and gently convex below. Hind wing large, obliquely flat, with a postero-superior angle of about $100^{\circ}$, and defined by a straight oblique line from behind the umbo meeting the posterior margin not quite halfway down. Contour of surface transversely convex across the line of greatest elevation, which runs near the front side from the apex to the postero-inferior corner in a gently sigmoid sweep, the convexity increasing in front of it and gradually diminishing in rear of it. Shell marked by a few indistinct concentric growthbulges.

Size of Left Valve.-Height $45 \mathrm{~mm}$., length $57 \mathrm{~mm}$., depth, $7 \mathrm{~mm}$.

Locality.-Two specimens from Marwood and one from Barnstaple are in the Museum of Practical Geology, and one small specimen from Barnstaple in the Woodwardian Museum.

Remarks. - It has the appearance of being decidedly inequivalve. The specimens are almost in the condition of casts, lying in micaceous, ferruginous matrix, and having the surface destroyed. The margin does not lie in one plane, but is inversely sigmoid in front profile. 'T'he Woodwardian specimen is very mucb smaller than the others, but otherwise agrees with them, and shows the front wing to be nasute.

Affinities.-To Leptodesma potens, Hall, ${ }^{2}$ it bears some resemblance in general shape, though differing in being more acute below and less concave posteriorly.

1 Citerior, citimus.

2 1884, Hall, 'Pal. N. Y.,' vol. vi, pt. 1, p. 188, pl. xxi, figs. 21, 30 ; pl. xxii, figs. 11, 12, 19-21; and pl. 1xxxix, fig. 7 . 
2. Leptodesma, sp. Plate XIV, fig. 1, and Plate XVII, fig. 1.

Description.-Left valve large, convex, extremely oblique and transverse. Hinge-line straight, probably very much shorter than the length. Umbo small, acute, very oblique, and situated at or close to the anterior end. Anterior wing apparently very small, oblique and narrow, undefined. Posterior wing narrow, flattish, triangular, with a thickened rounded upper margin over the hinge-line, and apparently with a small rib or bead separating it from the body. Anterior margin very long, oblique, and almost straight. Postero-inferior parts very much produced. Contour of surface convex across the line from umbo to posteroinferior corner, becoming steep near the anterior margin. Surface unknown, but evidently having some growth-ridges which become concave on the hind wing.

Size.-A specimen, defective behind, is $27 \mathrm{~mm}$. high and $40 \mathrm{~mm}$. long.

Localities.-In the Barnstaple Athenæum is a specimen from Pilton; and in Mr. Hamling's Collection another from the beach at Croyde.

Remarks.-Though these specimens are much too defectire to enable us to give a full description, they seem to point to a remarkable and very distinct species, which (even allowing for possible distortion) was evidently characterised by its oblique mytiliform shape, though it doubtless belongs to the present genus.

Affinities. - From Pterinea ventricosa, as given by Goldfuss, ${ }^{1}$ Phillips," Follman, ${ }^{3}$ and Frech ${ }^{4}$ (though the versions of these authors do not seem always to agree with each other), it distinctly differs by its great obliquity and length, and by the shape of its wings.

From A. sublamellosa, F. A. Römer, ${ }^{5}$ it is distinguished by its length, obliquity, and short front wing.

\section{Leptodesma culteliatum, n. sp. Plate XIV, figs. $2,2 a$, 3.}

Description.-Right valve small, very elongate and oblique, sabre-shaped, gently convex, with small defined wings. Umbo small, acute, prominent, hardly elevated above the hinge, and situated at the anterior one-eighth of the shell. Hinge-line short, straight, about half the length of the shell. Wings flat, sharply defined by impressed bounding lines. Front wing small, long,

1 1834-40, Goldfuss, 'Petref. 'Germ.,' vol. ii, p. 134, pl. cxix, fig. 2.

2 1841, Phillips, 'Pal. Foss.,' p. 49, pl. xxii, fig. 82.

3 1885, Follman, 'Verh. Nat. Vereins Rheinl.,' Jahr. 44, vol. xlii, p. 191, pl. v, fig. 7.

4 1891, Frech, 'A Abhandl. Geol. Specialk. Preuss.,' Band ix, pt. 3, p. 97, pl. x, figs. 1-1c.

5 1850, F. A. Römer, ‘ Beitr. Harzgeb.'’ pt. 1, p. 13, pl. iii, figs. $4 a, b$. 
subtrapezoidal or tongue-shaped, bounded by a sigmoidal margin. Hind wing very narrow, triangular, bounded by a concave margin. Front margin very oblique, convex on the wing, concave at the base of the wing, and then gently convex below the wing, passing insensibly into the long, slightly convex, and oblique inferior margin. Postero-inferior corner very greatly produced, narrow and deeply convex. Posterior margin very oblique, slightly concave, with a curvature increasing upwards, meeting the hinge-margin at a right angle. Contour of shell gently convex, but steep posteriorly behind the line from umbo to the postero-inferior corner. Surface of back and wings covered by crowded minute, regular, parallel, distant, sharp concentric lines, and by a ferv irregular prominent growth-bulges.

Left valve differing from the right by having its sharp umbo rather elevated above the hinge-line, and its anterior wing convex and less defined.

Size.-Height $13 \mathrm{~mm}$., length $30 \mathrm{~mm}$, depth of both valves about $4 \mathrm{~mm}$.

Localities.- In the Museum of Practical Geology is a slab (and its counterpart) containing the two valves in close proximity from Braunton; and in the Porter Collection is a specimen of the joined valves from Pilton, a left valve from Roborough, and another from Poleshill.

Remarks. - While not in actual contact, the two valves from Braunton doubtless belonged to the same animal; though, lying in different directions on a slab that has suffered contortion, their dimensions are rather different. The minute concentric ornament is remarkably regular; over the posterior slope its threads become rather stronger and more distant.

Affinities.-Avicula innotata, Barrande, ${ }^{1}$ is a shorter shell with a longer hind wing and different ornament.

4. Leptodesma anatinom, n. sp. Plate XIV, figs. 4-6.

? 1889. Avicula, sp., Kayser. Abhandl. Konig. Preuss. Geol. Landes., n. s., pt. 1, p. 19, pl. vii, fig. 9.

Description.-Left valve moderate in size, subquadrate, oblique, transverse, moderately convex. Umbo rather prominent, obliquely incurved, proximate, extending slightly above the hinge-line, and situated at the anterior third of its length. Anterior wing large, broad, subtriangular, and defined by a distinct, nearly vertical line from the front of the umbo. Posterior wing large, flattish, triangular, defined, not reaching quite so far back as the postero-inferior point. Anterior margin oblique, slightly incurved under the wing, and fuller below.

1 1881, Barrande, 'Syst. Sil. Bohême,' vol. vi, pl. ccsxix, figs. 11, 1-5, Et. E. 
Inferior margin gently and evenly convex. Postero-inferior corner broadly rounded. Posterior margin gently concave. Hinge-line straight, and very nearly equal to the greatest length of the shell. Contour of surface convex in the centre, steeper in front, and slightly concave behind the umbo. Surface covered with numerous, very irregular, prominent growth-lines.

Right valve transverse, convex, subtriangular, oblique. Umbo smaller and narrower than that of the left valve, and not reaching above the hinge-line. Anterior wing convex, rather narrow, defined by an indistinct oblique line from the apex. Posterior wing long, narrow, concave, undefined. Anterior margin long, very oblique, slightly and broadly concave under the wing. Postero-inferior margin convex. Posterior margin apparently incurved. Contour of surface steeply convex across line from umbo to postero-inferior corner, being steeper behind than in front. Surface apparently similar to that of the other valve. Hinge-line long, bearing two very long, slight, horizontal lines, like teeth or ligamental grooves, behind the umbo. Anterior muscle-scar large, deep, circular, situated in the centre of the anterior wing, just in front of the umbo.

Size.-Left valve: height $19 \mathrm{~mm}$., length $29 \mathrm{~mm}$., depth about $4 \mathrm{~mm}$. A right valve measures $13 \mathrm{~mm}$. high, $25 \mathrm{~mm}$. long, and about $3 \mathrm{~mm}$. deep.

Locality.-There are two left valves and one right valve from Pilton in the Porter Collection.

Remarks.-Mr. Porter's fossils are in a fair state of preservation for these beds, and seem to be sufficient to define the species. Although the right and left valves are on different slabs, their agreement is such as to leave no doubt that they belong to the same species.

Affinities.-It presents much similarity to Avicula crenato-lamellosa, Sandberger, ${ }^{1}$ as given by Frech, ${ }^{2}$ but the present evidence points decidedly to its distinctness from it. In our specimens the front wing is much larger, and the posterior side less concave, and there are no signs of the existence of any radiations. A. pseudo-lavis, Follman ${ }^{3}$, and Ehlert ${ }^{4}$, is regarded by Frech as a synonym of Sandberger's shell. It appears to be distinguished from our specimens by its scalloped concentric striæ, by its greater height and more elongate hind wing, and by other points.

Pteronitella venusta, Billings, ${ }^{5}$ of the Upper Silurian seems longer and narrower, with a smaller umbo and a smaller front wing.

The Ludlow shell which Sowerby identifies doubtfully with Pterinea retroflexa,

1 1853, Sandberger, ‘Verst. Rhein. Nassau,' p. 288, pl. xxix, fig. 16.

2 1891, Frech, 'A Abhandl. Geol. Specialk. Preuss.,' Band ix, pt. 3, p. 49, pl. iv, fige. 5-5 c, and $13-13 b$.

3 1885, Follman, 'Ver. n. Vereins Rheinl.,' vol. 42, p. 199, pl. v, figs. $2,2 a$.

4 1882, CEhlert, 'Mém. Soc. Géol. Fr.,' ser. 3, vol. ii, p. 23, pl. iii, figs. 5, 5 a.

5 1874, Billings, 'Palæoz. Foss. Canada,' vol. ii, pt. 1, p. 142, pl. ix, figs. 5-5 b. 
Hisinger, is congeneric, and is evidently closely allied. The specimens of it in the Museum of the Geological Society show great variability, but appear distinguished by their larger hind wing, which extends beyond the postero-inferior corner. As Sowerby points out, ${ }^{1}$ it is most improbable that the Silurian species can be the same as Hisinger's form, if it be Jurassic. ${ }^{2}$

\section{Genus-Leiopteria, Hall, 1883.}

\section{Leiopteria Conradi, Hall? Plate XIV, fig. 7.}

?? 1881. Avicula (Pterinea?) serviens, Barrande. Syst. Sil. Bohême, vol. vi, pl. cexxiii, figs. 2, 1-9, Et. E.

? 1884. Leiopteria Conradi, Hall. Pal. N. Y., vol. v, pt. 1, p. 159, pl. xx, figs. $1,2,4$; and pl. Ixxxriii, figs. $1-4$.

Description.-Shell small, oblique, rather transverse. Hinge-line equal to the length of the shell. Umbo small, acute, prominent, slightly elevated, and situated close to the anterior end. Front wing very small, rounded. Hind wing large, long, flat. Anterior and inferior margin long, oblique, gently curved. Posterior margin long, deeply sigmoid. Contour very convex across the line from the umbo to the postero-inferior region, in front of which it arches gently to the margin, and behind which it sinks with a sigmoid curve to the hind wing. Surface covered with rather numerous, concentric, irregular undulations, which appear to have probably been covered by finer striæ.

Size.-Height about $14 \mathrm{~mm}$., length about $16 \mathrm{~mm}$., depth of valve about $5 \mathrm{~mm}$.

Localities.-One specimen is in the Woodwardian Museum from Barnstaple; and another in Mr. Hamling's Collection from near the Old Kiln at Croyde Bay.

Remar\%s. - These specimens are very imperfect, the first being a cast and defective in front, and the second being compressed in front, and affected by lines of pressure which have obscured the ornament. It appears, however, that they certainly belong to the genus Leiopteria; that, though differing considerably in some particulars, they probably belong to the same species; and that they are so very similar to $L$. Conradi, Hall, as probably to be identical with it. If so, the English shells probably belong to a dwarfed variety of that species.

Affinities. - Leiopteria Delayi, Hall, ${ }^{3}$ is less transverse, and has a much broader wing.

1 1839, 'Sowerby, in Murchison's 'Sil. Syst.,' p. 609, pl. v, fig. 9.

2 1826, Hisinger, 'Act. Holm.,' pl. vii, fig. 9 ; and 'Petr. Suec.,' p. 57, pl. xvii, fig. 12.

3 1884, Hall, 'Pal. N. Y.,' vol. v, pt. 1, p. 164, pl. xx, figs. 16-18; and pl. 1xxxviii, figs. 5-10. 
Avicula Bodana, F. A. Römer, ${ }^{1}$ appears to be more transverse, with a longer hinge-line, larger wings, and a straighter posterior margin.

Avicula Gervillei, Ehlert, ${ }^{2}$ is a shorter, deeper, and less oblique shell, with a broader and less defined posterior region.

Avicula serviens, Barrande, seems very closely to resemble it; but its hind wing seems generally rather shorter, and its surface sometimes retains fine rays; and it is therefore probable that it is distinct.

\section{Leiopteria? yurata, n. sp. Plate XIV, fig. 8.}

Description.-Right valve moderately small, flattish, transverse, oblique. 'Umbo apparently rather acute, elevated. Anterior side rather broad. Anteroinferior corner rather produced, broadly convex. Inferior margin wide, gently and evenly convex. Postero-inferior corner produced, convex. Front wing small, flat. Hind wing apparently large, broad, flat. Contour slightly convex vertically, almost flat on the back horizontally. Surface covered by regular, parallel, very distant, elevated ridges, which seem to incline backrards from the margins, to be truncated by a narrow groove on their summits, and to be separated by very wide and shallow smooth interspaces.

Size.-About $25 \mathrm{~mm}$. high, $33 \mathrm{~mm}$. long.

Locality.-A specimen of the right valve from Barnstaple is in the Woodwardian Museum; and one, which seems to be the mould of a corresponding left valve, is in my Collection from Upcott Arch Quarry.

Remarks.-These fossils evidently appear to belong to a distinct species, but they are unfortunately too imperfect to give a satisfactory conception of it. It bears a curiously strong superficial resemblance to Ctenodonta lirata, so strong that both specimens were at first mistaken for that shell. The likeness is, of course, entirely deceptive. It is evidently a Leiopteria, though both in shape and in ornament it differs distinctly from kindred forms.

\section{Genus-Pтүснортевia, Hall, 1883.}

It " differs from Actinopteria in the nasute anterior extremity, and large, straight wing, marked by a strong longitudinal fold. Hinge-line narrow, linear ; furnished with one or two linear, oblique, cardinal and lateral teeth. Surface with fine rays."

1 1860, F. A. Römer, 'Beitr. Harzgeb.,' pt. 4, p. 162, pl. xxv, fig. 9.

2 1881, CEhlert, 'Mém. Soc. Géol. Fr.,' ser. 3, vol. ii, p. 22, pl. iii, figs. 5, 5 a. 
Hall thus defines his genus, giving $P$. Salamanca, Hall, as an example. It accurately covers the English species.

1. Ptrchopteria Damnoniensis, Sowerby, sp. Plate XIII, fig. 14; and Plate XIV, figs. 9-13.

1810. Avicula Damroniensis, Souerby. Geol. Trans., ser. 2, vol. v, pt. 3, pl. liii, fig. 22.

1841. - - Phillips. Pal. Foss., p. 51, pl. xxiii, figs. 90-92.

1841. - caxceliata, Phillips. Ibid., p. 49, pl. xxii, fig. 84.

? 18S4. Prerinea, cf. Damroviexsis, Clarke. Neues Jahrb. f. Min., Beil.-Band 3, p. 372.

? 1884. Ptrchopteria Salancarca, Hall. Pal. N. Y., vol. v, pt. 1, p. 131, pl. xxiii, figs. $17-20$.

? 1884. - SAO, Hall. Ibid., p. 132, pl. xxiii, figs. 16, 23.

1893. Aricela Damroxiensis, Collins. Trans. Roy. Geol. Soc. Cormmall, vol. xi, p. 35.

Description.-Shell rather large, convex, inequivalve, subtrigonal, generally very transverse. Hinge nearly as long as shell, straight. Umbo broad, proximate, situated very anteriorly, curving forward, low in the right valve, prominent and overhanging the hinge in the left valve. Anterior wing small, narrow, subtriangular, with an obliquely convex margin below, apparently meeting the hingemargin at an acute angle. Inferior margin very long, oblique, and slightly convex. Postero-inferior corner much produced and very convex. Posterior margin oblique, straight. Hind wing long, triangular, rather broad, convex along its centre, and separated from the body by a strong linear concavity. Surface covered by very numerous, minute, equal, close, rounded ribs, crossed by a few strong growth-ridges, and by very numerous fine, close, rounded threads. Left valve more convex than the right.

Size.-Three specimens measure $23 \mathrm{~mm}$. high by $40 \mathrm{~mm}$. long, and $13 \mathrm{~mm}$. deep; $14 \mathrm{~mm}$. high by $18 \mathrm{~mm}$. long, and $5 \mathrm{~mm}$. deep; $32 \mathrm{~mm}$. high by $40 \mathrm{~mm}$. long, and $13 \mathrm{~mm}$. deep. A specimen from West Angle is $47 \mathrm{~mm}$. long.

Localities:-In the Barnstaple Athenæum are six specimens from Sloly, five from Marwood, one from Kingdon's, Shirwell, and two from Top Orchard. In the Museum of Practical Geology are eighteen from Marwood, one from Baggy, and eight from West Angle Bay, Pembrokeshire; in the Woodwardian Museum, Sowerby's type from Marwood, and six from Barnstaple; in my Collection one from Pouch Bridge. It crowds the surface of a bed just above the Rh. laticosta bed at Baggy. 
Remarlis.-Avicula Damnoniensis, Sow., as obtained from Marwood, varies so very much in shape, that it was divided by Phillips into three varieties; it appears probable, however, that this is in a large degree due to the squeezing of the beds and the decayed state of the specimens, in which the ornament is more or less destroyed. Still it is probable that the species did really vary considerably.

The shells from the Pilton beds were separated as A. cancellata by Phillips, but there seems no good reason for this. They are perhaps smaller, more compact in shape, and very regularly ornamented, but these points are probably due to individual accident or to preservation. Sorverby's type seems to agree with a fine specimen from West Angle Bay, which shows from different parts of its surface that, though the hind wing may in some states of preservation seem without radiations, it really possessed them; but the absence of radiations on the wing is the only character which Phillips mentions as definitely distinguishing Sowerby's species from his own; while another character (the contour of the hind wing) which Phillips mentioned in $A$. cancellata is equally seen in many Marwood specimens of A. Damnoniensis. Probably if the latter specimens were in good preservation the supposed differences would disappear.

It appears probable that $P t$. Salamanca, Hall, is also identical. In the defective state of our specimens it is difficult to be sure of exact details of shape, but any discrepancies that may be observable are such as might easily be accounted for by incidental causes. Moreover the differences between Pt. Salamanca, Hall, and Pt. Sao, Hall, seem so slight that they can hardly be more than varietal in a group of shells which we know from other species to be subject to much individual variation.

Affinities.-From the South Devon species of Actinopteria, as well as from Actinopteria intermedia, Ehlert, ${ }^{1}$ sp., it is distinguished by the shape of its wing and the fineness of its ornament.

5. Genus-Aviculopecten, $M^{\circ} \mathrm{Coy}, 1852$.

1. Avicolopecten transversos, Sowerby, sp. Plate XVI, figs. 1-4.

1840. Pecten transversus, Solverby. Geol. Trans., ser. 2, vol. v, pt. 3, pl. liii, fig. 3.

\begin{tabular}{|c|c|c|}
\hline 1841. & - & Phillips. Pal. Foss., p. 46, pl. xxi. fig. 77. \\
\hline & - & IF Coy. Syn. Carb. Foss. Ireland, p. 101. \\
\hline 9 & - & $\begin{array}{c}\text { Collins. Trans. Roy. Geol. Soc. Cornwall. } \\
\text { vol. xi, p. } 36 .\end{array}$ \\
\hline
\end{tabular}

1 1881, CEhlert, 'Mém. Soc. Géol. Fr.,' ser. 3, vol. ii, p. 21, pl. iii, figs. 1-1 c. 
Description.-Right valve large, probably nearly circular, flattish, with small, nearly equal, and well-defined wings. Umbo nearly central, acute, depressed, proximate, not elevated above the hinge-line. Front wing flat, narrow, with an oblique conrex margin, meeting the hinge-line at right angles, and defined below by a deep, oblique sinus. Posterior wing narrow, triangular, with a concave margin, meeting the hinge-line at right angles, and defined below by a less definite sinus. Anterior margin deeply notched under the wing, produced centrally, and broadly and evenly convex. Inferior and posterior margins convex. Surface of back ornamented by numerous sharp, triangular rays (divided by deep linear furrows) which are simple near the umbo, but, as they recede from it, develop a smaller similar ray on each side, so that near the margins they form groups of three triangular ridges, of which the central is the highest; the whole surface being crossed by numerous regular, fine, sharp, distant threads or stria. Surface of front wing with four or five strong, rounded ridges, divided by similar furrows, crossed by numerous fine, rounded striæ. Surface of hind wing with more numerous and indistinct rays, crossed by rather more irregular striæ.

Left valve very similar, but probably rather deeper, and with a larger, broader, and less defined hind wing:

Size.-Phillips's figured specimen is $51 \mathrm{~mm}$. long, but is vertically compressed. Other specimens are still larger, but I have been unable to find any that give the true dimensions, all the specimens having suffered distortion.

Localities.-In the Museum of Practical Geology is Phillips's figured specimen from Brushford, and a second from Braunton. In the Barnstaple Athenæum are two fine specimens from Goodleigh and Pilland, and a poor one from Top Orchard; in the Porter Collection are two specimens from Pilton; and in the Woodwardian Museum are five specimens from Barnstaple and one from South Petherwyn.

Remarks. - Though always distorted, several of the specimens are very fine, and enable us to learn a good deal of the character of the shell.

Phillips, though adopting Sowerby's name, remarks that he has very little doubt that it is the same shell as Pterinea radiata, Goldfuss. ${ }^{1} \mathrm{M}^{\circ} \mathrm{Coy}$, however, points out that it is distinct from that species. It is distinguished by its radiated wings, and its more numerous and finer ribs of nearly equal size, grouped with remarkable regularity in a different way from those of the German form, which, moreover, has wider interspaces.

1 1834-40, Goldfuss, 'Petref. Germ.', vol. ii, p. 135, pl. cxix, figs. $7 a, b$; and ? 1891, Frech, 'Abhandl. Geol. Specialk. Preuss.,' Band is, pt. 3, p. 19, pl. i, fig. 2. 
2. Avioulopecten nexilis, Sowerby, sp. Plate XVI, figs. 5, 6, and Plate XVII, figs. 2, 3 .

1840. Pecten xexilis, Sowerby. Geol. Trans., ser. 2, vol. v, pt. 3, pl. liii, figs. 1, 2.

1891. Aviculopecten 1 QdisGranexsis, Frech. Abhandl. Geol. Specialk. Preuss., Band ix, pt. 3, p. 19, pl. i, figs. $1-l b$.

Description.-Shell small, rather flat (the right valve being apparently almost flat and the left gently convex), subcircular, probably very slightly oblique, nearly equilateral. Wings small, flat, triangular, broad, nearly equal, bounded by sigmoid margins, defined (especially the anterior wing) by strong straight sulci, which reach the margins. Lateral margins, deeply concave under the wings, and then becoming deeply convex in the lower parts, the posterior corner being slightly more produced. Inferior margin nearly semicircular. Hinge-line straight, rather more than half the length of the shell. Umbo of the right valve small, sharp, central, proximate to the hinge-margin; umbo of the left valve rather larger, deeper and more rounded. Contour of back slightly convex, deepest near the umbo, spreading out flatly to the margins. Surface covered with about fifty fine, sharp, minute, elevated, distant, alternating ribs, about half of which have divaricated from the centre; the whole crossed by equally numerous but still finer and smaller parallel concentric threads, which extend also over the wings. Wings with about seven radiating rays similar to those on the body of the valves.

Size. $-16 \mathrm{~mm}$. long, $17 \mathrm{~mm}$. high, and $4 \mathrm{~mm}$. deep (left valve).

Localities.-In the Museum of the Geological Society is Sowerby's type from Barnstaple; in the Barnstaple Athenæum, two specimens from Top Orchard and one from Braunton; in Miss Partridge's Collection, one from Upcott Arch Quarry; and in my Collection, several specimens from the Ostracod-bed close to the Laticosta bed at Baggy.

Remarls.-For a long time I was only acquainted with very imperfect specimens of this shell; but recently $I$ have found it occurring in abundance in the lower beds of Croyde Bay. There is no doubt of the identity of these fossils with the species as described by Sowerby.

Aviculopecten aquisgranensis, Frech, appears exactly identical in every respect.

Affinities.-It is distinguished from $A$. Hallii by its very much finer and more numerous ribs. 
Pecten subradiatus, F. A. Römer, ${ }^{1}$ from the Culm, which is very similar in shape, is described as having numerous finer lines between the major rays.

Avicula Posidonis, F. A. Römer, ${ }^{2}$ is more transverse and squarish, with comparatively larger wings and finer rays, but in other respects is similar. If his specimen had been subject to considerable transverse contortion it might perhaps have approximated our species; but Römer seems to imply that its figure represents its true shape, while specimens show that Sorverby's figure is not much contorted.

Pecten polytrichus, Phillips, ${ }^{3}$ as given by Römer ${ }^{4}$ and by Frech, ${ }^{5}$ differs in having smaller wings and umbo, broader sides, and a decidedly more rounded form, as well as a few of the rays somewhat greater than the rest. Phillips's own species is still farther removed; it differs from the shell which these German authors have identified with it by the very much greater inequality of its major and minor ribs, and is akin to, if not identical with, the species named Avicula Ibergensis by F. A. Römer. ${ }^{6}$

P. Helmerseni, Semenow et Möller, ${ }^{7}$ is similar, but has only transverse striations on its wings.

Crenipecten Winchelli, Meek, may be compared with it, though probably not congeneric.

Pecten oceani, Goldfuss, ${ }^{9}$ has much coarser ribs.

\section{Aviculopecten granulosus, Phillips, sp. Plate XIII, fig. 15.}

1841. Pecten aranolosus, Phillips. Pal. Foss., p. 46, pl. xxi, figs. $75 a, b$.

Description.-Shell small, obliquely ovate, as broad as long. Umbo small, oblique, acute, situated nearly at the anterior third of the length. Hingemargin straight, about half the length of the shell. Wings small, triangular, broad, flat, very sharply defined, and with gently sigmoid margins; the hind wing being rather larger and longer than the front. Other margins oval, the greatest convexity being in the postero-inferior region. Surface microscopically

1 1852, F. A. Römer, 'Beitr. Harzgeb.,’ pt. 2, p. 91, pl. xiii, fig. 19.

2 1855, F. A. Römer, ibid., pt. 3, p. 11, pl. iii, fig. 4.

3 1841, Phillips, ' Pal. Foss.,' p. 46, pl. xxi, fig. 76.

4 1860, F. A. Römer, 'Beitr. Harzgeb.,' pt. 4, p. 161, pl. xxv, fig. 5.

5 1891, Frech, 'Abhandl. Geol. Specialk. Preuss.,' Band ix, pt. 3, p. 16, pl. i, figs. 9-9 6.

6 1855, F. A. Römer, 'Beitr. Harzgeb.' pt. 3, p. 35, pl. vii, fig. 3.

7 1863, Semenow and Möller, 'Mélange Phys. et Chim.,' vol. v, p. 679, pl. iv, figs. $14 a, b$.

8 1875, Meek, 'Pal. Ohio,' vol. ii, p. 296, pl. xv, figs. 50, 56 ; and 1884, Hall, 'Pal. N. Y., vol. v, pt. 1, p. 89, pl. ix, fig. 1, 2, 4, 25-30.

9 1834-40, Goldfuss, 'Petref. Germ.,' vol. ii, p. 42, pl. Ixxxviii, fig. 10. 
crenulated by very numerous sharp radiating and concentric lines, which together cover it with a multitude of minute squares; surface of front wing similar but slightly coarser; that of hind wing much coarser, and with the transverse lines dominant. Contour of left valve gently convex.

Size of Right Valve.-Length $14 \mathrm{~mm}$., height $14 \mathrm{~mm}$.

Localities.-There are two specimens from Pilton in the Porter Collection, and one from Landlake in the Museum of Practical Geology.

Remarles. - The two specimens from Pilton closely agree with Phillips's figure of the opposite (?) valve, and are evidently identical though they do not preserve any signs of the ornament except on the hind wing. The ornament on the Landlake specimen is exactly like that in Phillips's figure, except that it is still more minute. That specimen is rather more oblique and transverse, but it is quite possible that (as it is a mould) it might have been the original of his figure in spite of its appearing to represent the opposite valve. It is flatter than the Pilton specimens.

Affinities.-Pecten linteatus, Goldfuss, ${ }^{1}$ is very similarly ornamented, but appears to be longer and more direct, and to have more rounded rays and considerably larger wings.

Aviculopecten pelmensis, Frech, ${ }^{2}$ more nearly approaches it in shape, but bears much fewer and coarser radiations.

\section{Genus-Actinopteria, Hall, 1883.}

1. Actinopteria rudis, Phillips, sp. Plate XV, fig. 14 .

1841. Avicula rudis, Phillips. Pal. Foss., p. 50, pl. xxii, figs. $85 a, b$.

? 1892. Acrinopteria rudis, Whidborne. Dev. Faun., vol. ii, p. 73, pl. viii, figs. 4, 6, $6 a$.

Description.-Left valve very high, slightly oblique, ovoid. Umbo prominent, extending above the hinge-line, situate anteriorly. Hinge-line short. Hind wing short, triangular, very broad, and clearly defined. Posterior margin forming a slightly obtuse angle with the hinge-margin, straight on the wing, and convex below it. Contour of back convex. Surface with numerous fine, sharp, distant rays, and a few indistinct undulations of growth. "Lower valve: general figure elongate, with a square, short hinge-line and prominent beak near the anterior end; surface covered with flexuous and irregular lines of growth" (Phillips).

Size.-A left valve measures about $15 \mathrm{~mm}$. high.

1 1834-40, Goldfuss, ' Petref. Germ.,' vol. ii, p. 78, pl. cxiv, fig. 9 ; and 1891, Frech, 'Abhandl. Geol. Specialk. Preuss., Band ix, pt. 3, p. 17, pl. ii, figs. 3-5.

2 1891, Freech, 'Abhandl. Geol. Specialk. Preuss.,' Band ix, pt. 3, p. 15, pl. i, figs. 7-7 b. 
Localities.-A specimen from Barnstaple and tro from south-west of Sloly in the Woodwardian Museum, and two very indistinct shells from Sloly in the Barnstaple Athenæum, appear to belong to this species.

Remar\%s.-Under this heading Phillips has figured two very indistinct valves from Pilton and Bradiford, viz. a left valve which closely resembles our specimens, and a right valve showing the concentric lines described by him.

Our fossils are all too indistinct to throw further light upon the species, or to enable us to be certain whether the Lummaton form is identical. While most of the specimens seem to have a rather large and rayed hind wing, in the specimen here figured it seems short and smooth. Though this certainly throws a little doubt on its identity, I am inclined to regard it as immaterial. The smoothness, at all events, seems simply due to accidental obliteration of ornament.

Affinities.-A. Jugleri, F. A. Römer, ${ }^{1}$ approaches it most nearly, but is more oblique, and, judging from the figures of it given by various authors, differs in other particulars.

7. Genus or Sub-genus-Pterinopecten, Hall, 1883.

1. Prerinopecten polytrichus, Phillips, sp. Plate XV, fig. 1.

1841. Pecten polytrichus, Phillips. Pal. Foss., p. 46, pl. xxi, fig. 76.

1855. Avicula Ibergensis, F. A. Römer. Beitr. Harzgeb., pt. 3, p. 35, pl. vii, fig. 3.

1884. Prerinea Imergexsis, Clarke. Neues Jahrb. f. Min., Beil.-Band iii, p. 370 .

1891. Avicuta Ibergensis, Frech. Abhandl. Geol. Specialk. Preuss., Band ix, pt. 3, p. 44, pl. iii, fig. 3.

Description.-Left valve very large, nearly flat, rather oblique, higher than long. Umbo probably very small, low, and situate at or about the anterior fourth of the length of the value. Hinge-line straight, nearly equal to the length. Margins unknown, but probably the inferior short, slightly oblique, and convex, the postero-inferior slightly produced and broadly convex, and the posterior nearly direct and gently sigmoid. Hind wing large, flat, broad, triangular, undefined, and with a nearly perpendicular margin. Contour of back gently convex near umbo, sloping out flatly to margins. Surface with about eight large, rounded, distant, radiating ribs, rapidly decreasing in size laterally, between each of which is an alternating series of seven very much smaller ribs, of which the fourth is the

1 1843, F. A. Römer, 'Verst. Harzgeb.'’ p. 21, pl. vi, fig. 4. 
largest and the second and sixth next in size; the whole crossed by seven or eight very low and indistinct undulations, and by very numerous fine concentric striæ. Surface of hind wing with about twenty small, equal, alternating ribs only.

Size of an imperfect valve.-Length $60 \mathrm{~mm}$., height $80 \mathrm{~mm}$., depth $8 \mathrm{~mm}$.

Locality.-One imperfect mould from Croyde Bay is in the Museum of Practical Geology.

Remarlis. - The figure of this fossil is given from a wax cast taken from the mould. It is very different in size, shape, and ornament from any of the accompanying fossils, but owing to its own imperfection, and to the unsatisfactory description of the forms with which it may be compared, there is considerable difficulty in deciding its species.

Phillips's figure of Pecten polytrichus is similarly ornamented. It appears smaller and more transverse, and its major ribs seem stronger behind than in front, but it has every sign of being taken from a very much compressed and fragmentary specimen, and it is the right or opposite valve to ours. It may be observed that Phillips defines two varieties, one with alternating minor ribs from Brushford, and the other with equal minor ribs from Mudstone Bay. The latter may prove to be a distinct species, but my belief is that the former at all events is identical with ours, and that the differences visible are to be accounted for either by distortion or by his specimen being only the umbonal parts of a larger shell.

Again, Avicula Ibergensis, F. A. Römer, appears from its figure to agree with our fossil in shape and character, chiefly differing in being much smaller and in having two major ribs on the hind wing. Frech, who refigures Römer's type, makes it even more like Phillips's specimen than ours. It seems probable that it is only a variety of the English fossil, the differences seen being simply due to age.

Affinities.-The shell identified by Römer ${ }^{1}$ and by Frech ${ }^{2}$ with $P$. polytrichus is totally different from Phillips's species, and may be easily distinguished both by its ornamentation and by its very much smaller wings.

Avicula dillensis, Frech, ${ }^{3}$ has a different and much simpler style of ornament on the left valve; though the right valve is more similar, differing, however, in having more numerous rays and much fewer concentric threads.

A. pectinoides, Sowerby, ${ }^{4}$ approaches it in size and shape, but has many more major ribs, and its ornament is, as is shown by $\mathrm{M}^{6} \mathrm{Coy},{ }^{5}$ of an entirely different nature.

1 1860, F. A. Römer, ' Beitr. Harzgeb.'’ pt. 4, p. 161, pl. xхv, fig. 5.

2 1891, Frech, 'Abhandl. Geol. Specialk. Preuss.,' Band ix, pt. 3, p. 16, pl. i, figs. 9-9 6.

3 Ibid, p. 39, fig. 2, pl. iii, fig. 9, and pl. xiv, fig. 17.

4 1840, Sowerby, 'Geol. Trans.,' ser. 2, vol. v, pt. 3, pl. liv, fig. 2.

5 1855, M`Coy, 'Brit. Pal. Foss.', p. 393. 
Myalinodonta Normaniana, d'Orbigny, sp., ${ }^{1}$ as given by Ehlert, ${ }^{2}$ differs specifically in the absence of major ribs, as well as generically in the absence of an anterior wing.

Aviculopecten transversus is easily distinguished by its obliquity being less, and by its ribs being piled up in groups.

2. Pterinopecten? Halli, n. sp. Plate XV, figs. 2-6.

? 1887. Aviculopecten, ef. Exacutus, Tschemyschew. Mém. Com. Géol., vol. iii, pt. 3, p. 45, pl. vii, fig. 7 .

Description.-Left valve small, convex, subcircular, not oblique. Umbo large, rounded, rather prominent, subcentral, subacute, proximate, and slightly elevated above the hinge-line. Anterior wing rather large, broad, triangular, slightly convex, sharply defined, with a convex margin meeting the hinge-line at about $100^{\circ}$. Posterior wing large, broad, triangular, undefined, with a concave margin meeting the hinge-line at an acute angle of about $60^{\circ}$. Hinge-line straight, nearly or fully equal to the length of the shell. Contour of back highly and evenly convex, perpendicular by the anterior, and rather steep by the posterior wing. Anterior margin long, convex round the wing, sharply concave at its base, and then broadly convex round the lower part. Inferior margin roundly and evenly convex. Posterior margin broad, sigmoid, nearly vertical. Surface of back covered (1) except on the extreme posterior part, with twenty-five to forty prominent, elevated, rounded, alternating, radiating ribs, becoming smaller rearward, and diminishing in number as they approach the umbo, and (2) on the extreme posterior part by a number of microscopic rays ; the whole crossed by twenty or thirty minute, sharp, regular, parallel, very distant threads. Surface of wings with five or six fine, distant radiations, and with rather coarser and closer transverse striæ.

Size of left valve.-Length $15 \mathrm{~mm}$., height $15 \mathrm{~mm}$., depth $5 \mathrm{~mm}$.

Localities.-In the Barnstaple Athenæum are four specimens from Top Orchard, one from Meer Top, and one from Roborough. In the Porter Collection is one from Pilton.

Remarles.-These specimens, though fairly preserved, are all more or less defective, especially about the wings, and all appear to be left valves. There is not, therefore, material fully to describe the shell, and it is of course possible that right valves described under another head really belong to it, though I do not at present know of any which there is any reason to match with it.

1 1849, d'Orbigny, 'Prodrome,' vol. i, p. 87.

2 1882, CEhlert, 'Mém. Soc. Géol. Fr.' ser. 3, rol. ii, p. 30, pl. v, figs. 1-1e. 
It appears referable to the genus Pterinopecten. The front wing is very definite, and the adjacent front boundary of the back is long, straight, and deep; the hind wing is more diffuse and broad. The transverse threads are so delicate that they are only occasionally visible or preserved. The ribs are rather irregular, a few being larger than the rest; toward the rear, they become smaller and more even, and then, as a rule, suddenly cease, the last rib reaching the margin above the postero-inferior corner. The space behind this seems smooth, but is really covered with microscopic rays, and upon it the transverse threads become very prominent.

Affinities.-From Pecten alternatus, Phillips, ${ }^{1}$ it differs by its smaller and more numerous ribs, and by its sharp transverse threads. The latter character may, however, perhaps only be due to a better state of preservation; and the former is weakened by the fact that while our specimens have usually about thirty rays, in one case they are reduced to twenty. Phillips gives the number as about twelve and represents them as very much larger, closer, and rounder; so that there seems sufficient reason to regard his species as distinct.

Aviculopecten (Pterinopecten) dauniensis, Frech, ${ }^{2}$ approximates it, but is more oblique, with a smaller umbo, larger wings, and decidedly fewer and coarser rays and concentric ridges.

3. Pterinopecten scabriradians, n. sp. Plate XV, figs. 8, 9; and Plate XVII, fig. 4 .

Description.-Right valve small, flat. Umbo small, apparently central, not elevated above the hinge-line. Hinge-line probably as long as the shell. Front wing very long, deeply notched, and extremely narrow, with a long, very oblique, slightly sigmoid margin, and separated from the body by a straight, deep, oblique groove. Lower margins apparently convex. Hind wing undefined. Surface bearing rather numerous, close, strong, rounded, highly nodulated rays, which frequently divaricate, and are separated by linear furrows, sometimes perhaps crossed by undulations. Surface of front wing with two very strong nodulated rays near the hinge, and smooth below.

? Left valve very convex, subcircular. Umbo acute, elevated above the hinge. Hind wing large, very broad, triangular, flat, bounded by a straight margin, and rather well defined by a line from the umbo to the margin. Lower margin apparently almost evenly convex. Surface covered by about twenty very distant, narrow, elevated, sharpish rays, crossed by and nodulated by still more distant, regular, parallel, concentric lines, enclosing with the rays flat oblong interspaces.

1 1841, Phillips, 'Pal. Foss.,' p. 47, pl. xxi, fig. 78.

2 1891, Frech, 'A Abhandl. Geol. Speciall. Preuss.,' Band ix, pt. 3, p. 22, pl. i, figs. 8-8 6. 
Size.-Height $11 \mathrm{~mm}$., length $12 \mathrm{~mm}$.

Localities. - A small distorted right valve, from the lane between Wrafton and Heanton, is in my Collection. A slab containing a similar right valve, together with a left valve which may belong to the same species, is in the Porter Collection from the neighbourhood of Pilton.

Remarles.-Whether these two valves, which are differently ornamented, belong to the same species remains to be proved. It appears safest so to regard them, as they occur together on one block of stone, and each seems quite different from any other Pilton species.

The first figured specimen of the right valve is worn and defective; a specimen found since shows that the rays bear strong transverse tubercles on their summits. What indications there are of transverse lines tend to confirm the identity of the two valves.

Affinities.-The left valve closely approximates Pterinopecten exfoliatus, Hall, ${ }^{1}$ but appears to have a sharper and less oblique umbo; while the radiations on our right valve are not obsolescent. It is possible that better specimens might prove it identical with one, if not both of our valves.

Pt. undosus, Hall, ${ }^{2}$ though different in ormament, has the front wing as deeply defined and notched as that of the present species.

Some species of Aviculopecten given by Hall do not differ very greatly; in fact, Pterinopecten and Aviculopecten so run into each other that it seems difficult to find a line of demarcation.

Pecten xqualis, $\mathrm{M}^{\circ} \mathrm{Coy},{ }^{3}$ has fewer rays and a smaller and more definite hind wing than is seen in our left valve.

Aviculopecten Neptuni, Goldfuss, ${ }^{4}$ sp., as given by Frech, ${ }^{5}$ approaches our left valve in shape and general appearance, though not in size, ornament, or convexity ; but it differs much from our right valves.

4. Pterinopecten Austeni, F. A. Römer, sp. Plate XV, figs. 10, 10 a, 11.

1855. Avicula Austeri, F. A. Römer. Beitr. Harzgeb., pt. 3, p. 37, pl. vii, fig. 16.

Description.-Left valve rather small, wider than long, flattish, slightly oblique, subcircular. Umbo rounded, prominent, proximate, situated somewhat

1 1884, Hall, 'Pal. N. Y.,' vol. v, pt. 1, p. 61, pl. i, figs. 16, 17 ; and pl. lxxxiii, figs. 6, 7.

2 Ibid., p. 72, pl. ii, figs. 10-19; and pl. lxxxii, fig. 7.

3 1844, M‘Coy, 'Syn. Carb. Foss. Ireland,' p. 89, pl. xv, fig. 13.

${ }^{4} 1834-40$, Goldfuss, 'Petref. Germ.,' vol. ii, p. 125, pl. cxvi, figs. $4 a, b$.

5 1891, Frech, 'Abhandl. Geol. Specialk. Preuss.', vol. ix, pt. 3, p. 18, pl. ii, figs. 1, 2. 
anteriorly, direct and extending slightly above the hinge-margin. Hinge-margin giving the greatest length of the shell, straight behind the umbo, and at rather a lower level and slightly oblique in front of it. Anterior wing rather small, broad, triangular, flat, defined by a depression running obliquely forward from the apex, and marked by two or three linear rays, and by eight or nine sharp, distant, regular, transverse ridges. Hind wing large, flat, broad, undefined. Anterior margin nearly straight and perpendicular above, and becoming obliquely rounded in the lower part, the curve continuing along the inferior margin, and the posteroinferior corner being roundly convex. Posterior margin perpendicular and slightly concave. Surface covered with about eighteen strong, steep, acute, triangular, elevated, very distant ribs, becoming stronger and more distant gradually from the rear forwards, and separated by broad, gently convex intervals; the whole crossed by thirteen or fourteen sharp, regular and regularly distant threads or subfoliaceous ridges, which are slightly concave between the rays. Rays produced into long marginal spines, so that the margin is, in the central parts at least, deeply scalloped. Lateral angles sharp and slightly acute.

Size of Valve.-Height $22 \mathrm{~mm}$., length $23 \mathrm{~mm}$., depth about $4 \mathrm{~mm}$.

Localities. - There are four specimens of the left valve from Pilton in Mr. Porter's Collection, and one from Barnstaple in the Woodwardian Museum. Römer found a specimen in the "first quarry north of Pilton on the way to Marwood."

Remarles. -This species was long ago founded by F. A. Römer on a Devonshire fossil, but it appears to have escaped the notice of English geologists, as I can find no reference to it in either Morris's or Etheridge's Catalogue, or elsewhere. Not having seen Römer's type specimen, I had intended to quote it simply on his authority; but in Mr. Porter's Collection I at once recognised four examples of it, one of which is almost perfect, and agrees in every respect with Römer's figure and description. He remarks that the concentric ribs are strongest on the swollen intervals, while they become small and form no clear knots upon the rays. The species is far removed from any other English Devonian species, and from any foreign species described by Frech, Hall, \&c.

5. Pterinopecten mundus, n. sp. Plate XV, figs. $12,12 a, 13,13 a$.

Description.-Shell large, oblique, convex. Left valve more or less convex, very oblique. Anterior wing small, narrow. Umbo minute, not elevated above the umbo. Hinge-line straight (in front of umbo), lined with three or four minute, parallel, transverse cartilage-furrows. Anterior margin short, convex, 
oblique. Inferior margin rather wide, convex, oblique. Postero-inferior margin widely rounded or semicircular. Posterior margin oblique, nearly straight. Surface covered with about twenty-three large, elevated, very rounded ribs, between which is a single similar series of much smaller ribs, separated by concave interspaces equal to the smaller ribs in width; the whole crossed by minute and indistinct close concentric striæ. Contour (in old forms) probably very steep, becoming almost perpendicular in front. Right valve apparently very similar to the other valve, very convex, with a large expanded wing in front.'

Size.-A small left valve is $24 \mathrm{~mm}$. high by $20 \mathrm{~mm}$. long. A larger valve is about $38 \mathrm{~mm}$. high by $32 \mathrm{~mm}$. long, and $8 \mathrm{~mm}$. deep.

Locality.-There are tro specimens in the Woodwardian Museum from Barnstaple, and another in the Museum of Practical Geology from Croyde.

Remarks.-All these three specimens are defective, and, though they clearly show the general character of this handsome species, are difficult to interpret in detail, and therefore the above description must be regarded as in a measure tentative.

The best specimen is a small, flattish left valve in the Woodwardian. This shows the small anterior wing, above which is seen the straight hinge (about $.5 \mathrm{~mm}$. wide), bearing three or four parallel ligamental furrows. With this fossil appears to agree the Croyde specimen, except that it is much more convex, and that the anterior side seems much more rounded, as though the anterior wing, which is gone, were much smaller. The other Woodwardian specimen is so distorted by pressure that it is impossible to make out its original contour; but its general shape and the large size of the ribs on the remaining wing (which is, however, evidently very much distorted) may possibly point to its being the opposite or right valve.

Affinities.-It may be near Pecten alternatus, Phillips, ${ }^{1}$ from South Petherwyn, but that shell is said to be not oblique, and is smaller, and has fewer, more elevated, closer, and more definitely alternating major ribs, while there are no signs of the minor series. Whatever, therefore, may be the shell which Phillips's figure represents, there is at present no sufficient reason to identify it with the present species.

Avicula rudis, Phillips, ${ }^{2}$ widely differs in having a very much more finely radiated left valve and a concentrically marked right valve.

1 1841, Phillips, 'Pal. Foss.,' p. 47, pl. xxi, fig. 78.

2 1841, ibid., p. 50, pl. xxii, figs. $85 a, b$. 


\section{Family-PeCtinide, Fleming, 1828. \\ 1. Genus-Crenipecten, Hall, 1883.}

I have placed the following shell under the present genus because I think I can see faint indications of a crenulated hinge-line, which, however, the roughness of the matrix renders very doubtful.

1. Crenipecten? auritus, n. sp. Plate XV, fig. 7 ? and Plate XVI, figs. 15, 16.

Description.-Right valve small, flat, short, direct. Umbo small, central, direct, acute, flattened, proximate, and not extending above hinge-line. Hingeline very nearly equal to the greatest length, apparently pitted or dentated. Anterior wing very large, broad, an almost right-angled isosceles triangle in shape, bearing indications of rays, and separated from the body by a deep hollow groove or sinus. Anterior and posterior margins almost straight and direct superiorly, convex inferiorly. Inferior margin short and convex. Contour very flat. Surface of back bearing ten or twenty very low, rounded rays.

Left valve rather more convex. Umbo small, extending slightly above the hinge-line. Anterior wing short, triangular, very broad, bearing a few rays, having a convex margin, and separated from the body by a deep straight groove. Surface (except the wing) covered by low, rounded, distant, irregular ribs, which do not all reach the umbo, and are separated by wider, shallow, concave inter. spaces.

Size.-Length $8 \mathrm{~mm}$., height $10 \mathrm{~mm}$.

Localities.-In the Barnstaple Athenæum are two specimens of the right valve from Top Orchard, and one of the left valve from Bradiford, and in the Porter Collection one left valve from Pilton, and another, which is doubtful, from Smoking House Lane.

Remarls. - This shell appears to be distinct, and probably rather far removed from the other species occurring in these beds. Owing, however, to the very poor state of preservation of the specimens its description is very difficult; and it has proved impossible to figure it in a satisfactory manner, the critical points being much obscured by the matrix, or by fracture of the shell.

The specimen from Bradiford, though indistinct, appears undoubtedly to be a left valve; and therefore it appears that we can identify the full shell, and may regard it as distinct from any other species which is known by only one of the valves. 
2. Genus-Pledronectites, Schlotheim, 1820.

(S'treblopteria, $\left.M^{\circ} \mathrm{Coy}, 1851.\right)$

Shell subequivalve, oval or subcircular; anterior side obliquely produced in front; hind wing large, confluent, with a right or obtuse terminal angle; front wings short, in the left valve defined by an oblique groove, and in the right indented by a byssal notch; surface smooth or finely radiated; muscular scar faint and above the centre; hinge with a narrow oblique tooth in front of the umbo; ligamental groove simple and narrow.

The above description is condensed from De Koninck's definition of Streblopteria, ${ }^{1}$ which is a genus with the Carboniferous Meleagrina lævigata, $\mathrm{M}^{\circ} \mathrm{Coy},{ }^{2}$ for its type. Frech ${ }^{3}$ points out that it is synonymous with Pleuronectites; and Pl. lavigata, Schlotheim, ${ }^{4}$ of the Trias, which is the type of that genus, though differing specifically, is evidently congeneric with M‘Coy's species.

\section{Pledronectites Pilironensis, n. sp. Plate XVI, figs. 7-9, 10 ?, 11 ?}

Description.--Right valve small, subovoid, broad, gently convex, more or less oblique. Umbo small, acute, direct, rather flattened, hardly extending above the hinge, and situated rather behind the middle. Hinge-line more than half the length of shell. Anterior wing long, narrow, convex, ovate, marked by four or five coarse low rays and some cross striæ; defined by a deep narrow groove, and bounded by a semicircular margin. Posterior wing short, flat, obtusely triangular, defined by a linear oblique groove. Anterior margin semicircular at the wing, then with a deep, narrow, angular notch, and then spreading out in a broad, bluntly subangular curve, which becomes subcircular below. Inferior margin narrow, convex. Posterior margin neatly convex. Contour of back gently convex, spreading out flatly to the margins. Surface apparently smooth (or only microscopically marked). Muscle-scar very large, central, situated in the upper half of the shell.

? Left valve ovoid, more or less broad and oblique, rather convex. Umbo oblique, acute, reaching slightly above hinge. Anterior wing small, flat, short, equilaterally triangular, and marked with a few radiating and transverse lineations. Posterior wing apparently small, short, flat, and very broad, more or less distinctly defined,

1 1885, de Koninck, 'Ann. Mus. Roy. H. N. Belg.,' vol. xi, p. 202.

2 1844, M'Coy, 'Syn. Carb. Foss. Ireland,' p. 80, pl. xii, fig. 5.

3 1891, Frech, 'A bhandl. Geol. Specialk. Preuss.,' Band ix, pt. 3, p. 12. fig. 11.

4 1820, Schlotheim, 'Petref.,' vol. i, p. 217; and 1850-56, Bronn, 'Lethæa,' ed. 3, p. 161, pl. xi, 
and with its margin confluent with the margin of the body. Margins generally convex, gently concave below the anterior wing. Contour of back gently convex.

Size.-A right valve is $15 \mathrm{~mm}$. long, $16 \mathrm{~mm}$. high, and $3 \mathrm{~mm}$. deep.

Localities.-In the Barnstaple Athenæum are one left and one right valve from Top Orchard, and left valves from Bradiford, Raleigh, and Kingdon's, Shirwell. In the Porter Collection are three or perhaps four right valves and two left valves from Pilton, and two left valves from Roborough. In my Collection is one doubtful right valve from Wrafton Lane.

Remarlis.-These specimens are for the most part in a poor state of preservation, and their surface is decayed or gone. They are extremely puzzling from the variety of shapes which they assume, owing probably to the tenuity of the shell. The right valves are, however, easily recognisable by their peculiar convex, radiated, pear-shaped anterior wing. Hence we can identify shells which are inversely oblique with others which are, apparently through squeezing, almost direct. The left valves are sometimes direct, but generally oblique in the opposite direction. It has seemed to me, however, after a careful examination, that this change of shape may be not improbably due to contortion, and therefore I have ventured to place them with these right valves, which otherwise correspond, though I fully realise that the discovery of better preserved specimens may prove them distinct. The figured right valves from Mr. Porter's Collection (Pl. XVI, figs. 7 and 8) should be regarded as the types of the species; that in the Barnstaple Museum would have to be separated if further discoveries were to prove that it is not distorted; while the only left valve that can be certainly referred to it is a very poor specimen of Mr. Porter's, the other left valves being only placed here provisionally until better specimens prove whether they are identical or not. Affinities. - Pecten consimilis, M'Coy, ${ }^{1}$ seems closely related, and has a similarly ornamented ear, but it differs in having its umbo larger and more central, and in being less oblique and very much smaller in size

Pecten perobliquus, F. A. Römer, ${ }^{2}$ seems more oblique and more produced in the postero-inferior part than our right valves, bears no rays on the ear, and has transverse striæ on the other parts.

Crenipecten obsoletus, Hall, ${ }^{3}$ and C. glaber, Hall, ${ }^{4}$ approach in shape, but neither of them appears to have a radiated ear, and they are probably more equilateral.

Streblopteria lateralis, de Koninck, ${ }^{5}$ comes very close, but does not appear to have a radiated ear, and appears more regularly ovoid in outline.

Meleagrina lævigata, $\mathrm{M}^{\circ} \mathrm{Coy},{ }^{6}$ seems decidedly more oblique and transverse.

1 1844, M‘Coy, 'Syn. Carb. Foss. Ireland,' p. 91, pl. xv, fig. 16.

2 1850, F. A. Römer, 'Beitr. Harzgeb.,' pt. i, p. 48, pl. viii, fig. 4.

${ }^{3} 1884$, Hall, 'Pal. N. Y.,' vol. v, pt. 1, p. 84, pl. ix, figs. 19, $21 . \quad{ }^{4}$ Ibid., p. 85, pl. ix, figs. 20, 22 ?.

5 1885, de Koninck, 'Ann. Mus. Roy. H. N. Belg.,' vol. xi, p. 206, pl. xxxii, fig. 16.

${ }^{6} 1844, \mathrm{M}$ ‘Coy, 'Syn. Carb. Foss. Ireland,' p. 80, pl. xii, fig. 5. 


\section{Pleuronectites leisis, n. sp. Plate XVI, figs. 12, 13.}

Description.-Left valve small, flat, circular, slightly transverse. Umbo low, flat, direct, central, acute, small. Hinge-line apparently about half the length. Anterior wing small, flat, triangular, rather narrow, defined by a strong, long, rather concave wall from the umbo. Posterior wing very small, short, undefined. Anterior margin rather concave at the wing, then sloping obliquely forward, and becoming broadly convex round the body of the shell. Inferior margin wide, gently convex. Posterior margin deeply convex below, becoming nearly straight and oblique round the posterior wing. Contour of back nearly flat, perpendicular and steep over the front wing. Surface marked by one or two strong growthlines, and apparently with very fine and regular concentric striæ. Right valve very similar to the left valve.

Size.-Height $15 \mathrm{~mm}$., length $18 \mathrm{~mm}$., depth of one valve $2 \mathrm{~mm}$.

Localities.-Two, or perhaps three, specimens from Top Orchard are in the Barnstaple Athenæum; and one from Pilton in the Porter Collection.

Remarls. - It is not very certain whether this is a good species. The flattish circular shape and general character appear to give a distinctive appearance; but in a deposit which has suffered so much from distortion it is exceedingly difficult to decide whether an apparent peculiarity of shape may not possibly be due to accident.' It appears, however, that there is sufficient reason to assume that it is distinct.

Affinities.-It seems rather similar to Aviculopecten Schulzi, Frech, ${ }^{1}$ in shape and in the smoothness of the valves, but it differs by having a less defined and angulated posterior wing. The wings in the German species, moreover, of which a right valve only is figured, are strongly radiated.

Streblopteria pullus, de Koninck, appears more equilateral, and has a more defined hind ring.

\section{Pleuronecrites Hicksit, n. sp. Plate XVI, figs. 14, 14 a.}

Description.-Left valve very small, convex, subcircular, higher than long. Umbo low, sharp, direct, incurved, and extending somewhat above the hinge-line. Hinge-line more than half the length of the shell. Anterior wing (probably short) broad, triangular, defined by a straight, steep, oblique line from the umbo.

1 1891, Frech, ‘Abhandl. Geol. Specialk. Preuss.,' Band ix, pt. 3, p. 21, pl. i, fig. 10.

2 18s5, de Koninck, 'Ann. Mus. Roy. H. N. Belg.,' rol, xi, p. 208, pl. xxxii, fig. 13. 
Posterior wing apparently obtusely triangular, small. Lower margins probably strongly convex. Contour very gently convex, becoming perpendicular or even rather excavate above the lines which bound the wings. Surface microscopically marked by crowded, regular, elevated, distant concentric threads, and similar but less regular and distinct radiating lines, and with a few transverse striæ on the front wing.

Size.-The specimens are too defective for measurement.

Localities.-A specimen from Bradford is in the Barnstaple Athenæum; and a very doubtful one from Pilton in the Porter Collection. One from the lane between Wrafton and Heanton, and another from Upcott Arch Quarry, are in my Collection.

Remarks.-This is another little species, of the nature of which we have at present very imperfect information. There seems no doubt that it is quite distinguishable from $\mathrm{Pl}$. Piltonensis, but I am not so certain whether $\mathrm{Pl}$. lepis may not prove to be a synonym of it. The fine concentric ornament is very characteristic, and appears to be different from that on the adjacent species.

Affinities.-The right valve of Pecten perobliquus, F. A. Römer, ${ }^{1}$ comes very near, but seems to differ in being shorter and much more oblique.

Pleuronectites devonicus, Frech, ${ }^{2}$ is closely approximate, with an exactly similar ornament, but having a smaller and radiated front wing and a rounder umbo. Its front wing seems nearer an equilateral triangle in shape, and the front margin is consequently more indented. It also appears to be a more globose shell.

\section{Genus-Pernopecten, Winchell, 1865.}

This genus is regarded by Zittel as a section of Crenipecten. Hall ${ }^{3}$ refers to it the Palæozoic (if not also the Jurassic) species of Entolium, Meek; and shows that, if identical, it has a priority of a few months over the latter.

Its hinge-line is described as straight, but in the type specimen as figured by Hall the wings protrude upward at least as much as in the shell described below.

1. Perxiopecten insperatus, n. $\mathrm{sp}$. Plate XVII, fig. 5.

Description.-Shell small, flat, nearly equilateral, subcircular; umbo flat, low, slightly anterior, small, rounded. Wings subequal, protruding to a moderate height

1 1850, F. A. Römer, 'Beitr. Harzgeb.,' pt. i, p. 48, pl. viii, fig. 4.

2 1891, Frech, 'A bhandl. Geol. Specialk. Preuss.,' Band ix, pt. 3, p. 13, pl. xvii, figs. 8, 8 s.

3 1885, Hall, 'Pal. N. Y.,' vol. v, pt. 1, sect. ii, p. lvii, woodeuts 1-3. 
above each side of umbo, subtriangular. Hinge-margin less than half the length of the shell, with two deep internal ridges extending obliquely downwards three quarters of its length. Margins subcircular. Contour flat, the umbonal area being defined in front by a slightly curved line, and behind by a strong straight depression, extending to the centre of the posterior margin. Surface (?).

Size.-Height $16 \mathrm{~mm}$., length $16 \mathrm{~mm}$.

Locality.-One specimen from Top Orchard is in the Barnstaple Athenæum.

Remarks. -The only specimen of this shell with which I am at present acquainted is so indistinct that $I$ at first omitted it from the plates, but further examination convinced me that it has protruding wings in the style of Amussium, and is therefore generically distinct from the other specimens with which I supposed it associated. These wings are lower and rounder than is usual in the species that have been referred to the genus Entolium, and its slightly inequilateral shape seems to distinguish it from most of the Belgian Carboniferous forms.

I am not aware that any other species of the genus has hitherto been described from Devonian rocks.

4. Prothyris, ${ }^{1}$ sp. Plate XVII, fig. 6.

Description.-Shell moderate in size, ensiform, very elongate, its length being about three times its height. Anterior margin apparently rounded and notched. Inferior margin very long and straight, and nearly parallel to the upper margin, the shell being slightly higher in front than behind. Posterior margin apparently gaping. Umbo low, rounded, situated at or about the anterior fifth of the shell. Surface marked with rather few close, low, rounded growth-lines, most visible in the marginal half, and with eight or ten rather strong, unequally distant, linear, oblique, impressed rays running from behind the umbo to the posterior fourth of the inferior margin. Post-cardinal slope apparently narrow, flat, oblique, and marked by a few much stronger radiating ridges.

Size.-Height $10 \mathrm{~mm}$., length $30 \mathrm{~mm}$.

Locality.-Two specimens are in my Collection from Sluly Quarry.

Remarks. - These specimens are interesting from the clearness of their peculiar ornament. They are too imperfect for identification, but one of them appears to show the characteristic notch of the genus, though in a much-injured condition. Both in size, shape, and ornament they seem so different from either of the species described above that I think they will prove distinct from any of them. 


\section{MOLLUSCOIDEA.}

\section{Class-BRaCHIOPODA, Duméril, 1806.}

1. Order-ARTiCUliata, Deshayes, 1836.

I. Family-Terebratulide, King, 1846.

1. Genus-Rensselueria, Hall, 1859.

1. Rensselleria? formosa, n. sp. Plate XVII, figs. 7-9.

Description.-Dorsal (?) valve elongate, convex, suboval, without a fold. Surface covered by about twenty low, close-set, flatly rounded ribs, which do not divaricate, but gradually increase in size from the umbo to the margins. Two lofty median septa, continued a short distance forward from the umbo, subparallel and not united, possibly supporting the hinge-plate, and surrounded by a low ovoid ridge, which starts near the umbo, and, passing just in front of them, may perhaps define a muscular area. Dental sockets lateral, triangular. Shellstructure very minutely and regularly punctate.

Size.-A slightly crushed valve is $26 \mathrm{~mm}$. long, by $16 \mathrm{~mm}$. wide, and $7 \mathrm{~mm}$. deep.

Localities.-Four specimens from Ashford Strand are in my Collection, and two from Pilton and Poleshill in the Porter Collection.

Remarks. - These specimens are all more or less imperfect. The first one discovered (fig. 7) had assumed almost the exact shape and appearance of Tropidoleptus carinatus (Conrad), and consequently I catalogued it as that shell. Further examination, and comparisons on the one hand with our Ashford specimens, and on the other with Davidson's figured specimens of T. carinatus, and with German specimens kindly lent me by Mr. Upfield Green, have proved that its umbonal arrangements agree with the former and not with the latter, and that the specimen orves its peculiar shape to excessive distortion. It therefore is proved not to be $T$. carinatus, and that species does not occur in the Pilton Beds.

The best of my specimens from Ashford appears to afford considerable information about this species, which is evidently beautiful and interesting, but perplexing withal. Externally it might well be referred to Renssellærio, but I cannot satisfactorily correlate what is seen of the internal details with those given by Hall for his 
genus. The pores of the surface suggest its affinity to the Terebratulidx or to Retzia. The cast (fig. 8 a) shows two short, deep, close, but unconnected subparallel fissures; on each side of these are shallow, slightly curved grooves, starting close to the apex, and meeting each other just in front of the fissures, so as to form a small ovoid fossula, which perhaps defines the muscle region; again on each side of this lie rather deep oblique fissures, which seem to be the moulds of the walls of the triangular dental sockets. These features do not tally with those of German specimens of $R$. stringiceps shown me by Mr. Upfield Green, nor do they seem as if they would be consistent with the structures described by Hall, even in an immature state. On the other hand, I am inclined to think that the shell is most likely to be allied to Renssellæria or Itrigeria, which it appears strongly to resemble in outward form and some other points. Consequently, as enough is not yet known about it to give a generic definition, it seems best to leave it provisionally under Renssellæria; observing, however, that it appears to me most probable that it will be found to require a new generic name when better specimens have been discovered.

Affinities.-R. stringiceps, F. Römer, ${ }^{1}$ differs in having much finer and more numerous ribs, $i$. e. forty instead of twenty. The Ilfracombe shell which Davidson ${ }^{2}$ refers to that species is further distinguished by its constant divarication of ribs. Again, the ribs of all the American forms given by Hall and Clarke are much finer and more numerous.

R. crassicosta, Kock, ${ }^{3}$ appears to have the same number of ribs, but, judging from the figures, the ribs are loftier, and the shell much more globose. There is, perhaps, still greater external resemblance in Centronella (Trigeria) Guerangeri, Verneuil, sp., ${ }^{4}$ but that is a much smaller shell.

\section{Family-SpIriferide, King, 1846.}

1. Genu-Атнугіs, $M^{\circ}$ Coy, 1841.

\section{Athris ? sp. Plate XVII, fig. 10.}

Remarks.-A few minute, smooth, flattish, elongate, oval shells were obtained by Mr. Porter from Pilton. In shape they appear to be peculiar, but they do not

1 1844, F. Römer, ' Rhein. Uebergangsgeb.,' p. 68, pl. i, figs. $6 a, b$.

2 1864, Davidson, 'Brit. Foss. Brach.,' vol. iii, p. 10, pl. iv, figs. 5-7.

3 1880, Gosselet, 'Esquisse Géol.,' vol. i, pl. i, fig. 20 ; 1881, Kock, 'Jahrb. f. Min.,' vol. ii, p. 387 ; and 1883, Kayser, 'Jahrb. Preuss. L. A.,' p. 123, pl. v, figs. 2-5.

figs. 1-6. 
show sufficient character to enable us to judge whether they are the young of some larger species, or one of those small Brachiopods which cannot be satisfactorily identified without some knowledge of their internal structure.

Sub-genus-Seminula, M`Coy, 1844 ; emend., Hall and Clarke, 1894.

2. Athyris (Seminula) oblonga, Sowerby, sp. Plate XVII, figs. 11, $11 a, 12$ ? $12 a$.

1840. Atrypa oblonga, Sowerby. Geol. Trans., ser. 2, vol. v, pt. 3, pl. liii, fig. 6.

? 1840 - - indentata, Sowerby. Ibid., pl. liv, fig. 6.

1864. Athyris?, Davidson. Brit. Foss. Brach., vol. iii, p. 17, pl. iii, figs. $1,16$.

1896. Aturris? овlongs, Whidborne. Proc. Geol. Assoc., vol. xiv, p. 375.

Description.-Shell slightly pentahedral (or suborbicular), subglobose. Ventral valve the larger; beak prominent, with short dental lamellæ; muscle-scars apparently very short and wide. Dorsal valve with very small dental sockets; musclescars short, cylindrical, and very narrow; hinge-plate broad, anteriorly straight. Cast of both valves covered with vascular impressions. Fold and sinus apparently only marginal, low, and not very broad. Surface quite smooth, but with four or five growth-ridges. Margins meeting in an arching line, the ventral valve being thrown back at the shoulders and then advancing to the front.

Size.-Length $19 \mathrm{~mm}$., width $19 \mathrm{~mm}$., depth $10 \mathrm{~mm}$.

Localities.-Ashford Strand, Laticosta Cave Baggy, Saunton, Poleshill, Roborough, \&c.

Remarles.-An internal cast with a portion of the mould of the same shell is in my Collection, and from this specimen the above description has been almost entirely taken. Judging from Hall and Clarke's revision of the Athyridæ this shell clearly falls within the limits of the sub-genus Seminula of $\mathrm{M}^{\circ} \mathrm{Coy}^{1}{ }^{1}$ of which they ${ }^{2}$ say that its smooth exterior, its subpentahedral form, its sinuate valves, and the peculiar character of its muscle-scars are distinctive features, and that branching vascular sinuses are sometimes retained over the whole pallial area of both valves. In our specimen all these points are observable, though its fold and sinus are very indistinct. Similar specimens seem not uncommon at Ashford, and a bed close to the Laticosta bed at Baggy is paved with valves, which from their shape and smoothness (excepting their few growth-lines) are undoubtedly identical. I have

1 1844, M'Coy, 'Synopsis Carb. Foss. Ireland,' p. 158.

2 1894, Hall and Clarke, 'Pal. N. Y.,' vol. viii, pt. 2, p. 93. 
also met with about twenty very similar casts in various collections, which appear to be indistinguishable, and which generally show more or less distinctly such points as the vascular sinuses, the subpentahedral shape, and the marginal fold, which rarely seems to be at all strong. With such unsatisfactory material it is of course difficult in many cases to be sure of specific identity ; for instance, the type of Atrypa oblonga, Sowerby, in the museum of the Geological Society is extremely obscure, and I long hesitated between identifying it with the above specimens, or with those referred below to Cleiothyris Royssii. Its oblong shape is, I think, evidently only due to distortion, but the character of the fold and the size of the dental sockets agree best with the present shell. Moreover Sowerby describes it as "smooth," as are also our specimens. But while, therefore, we may conclude that it belongs, and consequently gives its name, to the species now under consideration, we may. note that it is not in itself an exponent of its specific value.

For some time it seemed to me possible that our shell might belong to Athyris concentrica, von Buch, but having examined some casts from the Lower Devonian of Germany which Mr. Upfield Green informs me belong to that species, I find them to be entirely different and distinct.

The shape of our shell seems different from any of the various English Carboniferous forms of Seminula.

Sub-genus-Cleiothrris, King, 1850 ; emend., Hall and Clarke, 1894.

3. Athyris (Cleiothyris) Royssir, Léveillé. Plate XVII, figs. 13-15a ; Plate XVIII, figs. 1-5; and Plate XX, figs. 1, 2.

1835. Spirifer De-Rorssir, Léveillé. Mẹ́m. Soc. Géol. Fr., vol. ii, figs. 18-20.

1840. Atripa hispida, Sowerby. Geol. Trans., ser. 2, vol. v, pt. 3, pl. liv, fig. 4.

1840. - DeCussata, Sowerby. Ibid., pl. liv, fig. 5 .

? 1841. Spiritera decussata, Phillips. Pal. Foss., p. 70, pl. xxviii, figs. $120 b-e$.

1844. Athyris Decussata, M'Coy. Syn. Carb. Foss. Irel.,'p. 147.

1844. - DERRESSA, $\mathbb{L}^{\prime}$ Coy. Ibid., p. 147, pl. xviii, fig. 7.

1844. - HISPIDA, $M \Gamma^{\prime}$ Coy. Ibid., p. 148.

1855. - conometrica, $M \Gamma^{\circ} \mathrm{Coy}$ (pars). Brit. Pal. Foss., p. 378.

1861. - Rorssir, Davidson. Brit. Foss. Brach., vol. ii, pt. 5, p. 84, pl. xviii, figs. 1-11.

1864. Terebratola elongata ?, Davidson. Ibid., vol, iii, p. 8, pl. i, fig. 9.

1864. Athrris concentrica, Davidson (pars). Ibid., vol. iii, p. 14, pl. iii, figs.

1864. - sp., Davidson. Ibid., pl. iv, figs. 1-3. 15 (?), 17 (?), 24 (?) (only). 
1877. Spirigera Roissyr, Gosselet. Ann. Soc. Géol. Nord, vol. iv, p. 313.

1896. Athyris? concentrica and rugulosa, Whidborne. Proc. Geol. Assoc., rol. xiv, p. 375.

Description.-Shell, in the young state, transverse, flattish, with the ventral valve flattest, without fold or sinus. Ventral valve with small, deep adductor scars, and diffuse diductors. Dorsal valve with a central septum, thickened posteriorly, supporting a broad recurved hinge-plate, which seems to intrude into the beak, and the anterior corners of which support the short crura. Musclescars paired, each pair being elongate and narrow, while a small internal visceral foramen is seen just in front of the adductors. Spires consisting of about nine whorls, and filling the whole cavity of the shell. Surface covered with very numerous concentric ridges, which are often paired, and appear generally smooth, but sometimes show signs of spiniferous elongations.

Shell, in the older state, becoming large, and sometimes very transverse, with a narrow median septum and strong dental plates. Fold broad, flatly oval, protruding in front. Surface covered by extremely numerous lamellar striæ, which become more crowded and definitely spiniferous near the margins.

Size.-Large distorted fragments measure $30 \mathrm{~mm}$.

Localities.-Very common in most localities, e.g. Upcott Arch, Croyde Bay, Ashhill Quarry, Braunton Down, Incheldon, Pouch Bridge, Roborough, Poleshill, South Petherwyn.

Specimens figured by Davidson as Terebratula elongata, Schlotheim? and as Athyris concentrica, von Buch?, are in the Museum of Practical Geology; and others by Sowerby, as Atrypa hispida and A. decussata, are in the Woodwardian Museum.

Remarks.-Two forms, both of which are not uncommon in the Pilton Beds, appear to be the young and old states of the same species, and are united by some intermediate but less distinct examples.

(1) We have, first, small, flat, transverse casts, which are wide-spread and common (Pl. XVIII, figs. 1-3), and have been figured by Davidson as "Athyris, sp. ? supposed to belong: to A. concentrica." In these many internal details may be seen. In one specimen (Pl. XVII, fig. 15) the beginnings of the crura are preserved. The muscular scars and the spires are occasionally shown, and as the casts often occur in their moulds we can learn also the surface-ornament. This ornament generally seems to consist of smooth concentric ridges, but in some of the specimens these ridges are seen to be spiniferous, exactly corresponding with A. hispida, Sowerby, from South Petherwyn, so that there is no doubt that that species is identical with the present. A. decussata, Sowerby, is another South Petherwyn shell, which Sowerby also quotes from Barnstaple, and as his figure shows a similar ornament, it is doubtless only another example of the same 
species in a rather more advanced stage of growth. It may be compared with Pl. XVII, fig. 15.

With regard to these shells, however, it must be noted that it seems difficult to correlate their internal arrangements with those of Athyris. They agree in the small opening of the visceral canal in front of the muscle-scars; but there appear differences in the absence of defined ovoid dental sockets, in the strength of the median septum, and in the hinge-plate being apparently produced and curving forward into the beak. Possibly these structures may be due to the immaturity of the shell. They perhaps agree best with those of the sub-genus Seminula, as limited by Hall and Clarke, ${ }^{1}$ but according to them that group has a smooth exterior, while judging from the surface the present shell would fall within the sub-genus Cleiothyris as defined by them. ${ }^{2}$

(2) There are also frequently found, though almost always in an extremely crushed and distorted condition, much larger shells, which I formerly believed to belong to a distinct species. These show a broad flattened fold, and a surface of imbricated concentric lines, which appear very similar to those of the smaller form in the central parts, but which become closer and very definitely fringed and spinous marginally (Pl. XX, figs. 1 and 2). In one slab of these moulds in the Barnstaple Athenæum is a cast (the mould of which definitely shows the same surface-ornament) which is identically similar to the cast figured by Davidson as "Terebratula elongata, Schlotheim?," and therefore that name must be removed from our Devonian lists, as in them it is evidently only synonymous with that of the present shell. This cast bears much resemblance to the cast of Athyris lamellosa figured by Hall and Clarke. ${ }^{3}$

The question now arises whether this Devonshire species is identical with any previously described form. $\mathrm{M}^{`} \mathrm{Coy}$ unites it with $A$. concentrica, von Buch, and in this be is in part followed by Davidson. The character of the surface, however, seems clearly to negative this. Very indistinct radiations on the ridges of A. concentrica are certainly mentioned by von $\mathrm{Buch}^{4}$ and $\mathrm{M}^{6} \mathrm{Coy}$, but do not seem to break their continuity; and $\mathrm{M}^{\circ} \mathrm{Coy}$, when identifying Sowerby's shell with it, asserts that "the decussation, to which Sowerby alluded, is only produced by the decomposition of certain of the concentric laminæ, according with their original fibrous texture, and is not visible in sound specimens." But the evidence of our larger specimens distinctly disproves this assertion. In several of them the rows of puncta on the ridges (as seen in the mould) are much too definite to be explained in any such way; while in one or two (Pl. XX, fig. 1), where the surface is

1 1894, Hall and Clarke, 'Pal. N. Y.,' vol. viii, pt. 2, p. 93.

2 Ibid., p. 90.

3 Ibid., pl. xlvi, fig. 20.

4 1834, von Buch, 'Über Terebrat.,' p. 103. 
broken off aslant, rows of fine comb-like spines like those of Athyris Royssii are distinctly visible. Now Gosselet and Hall (for instance) distinguish A. concentrica by its want of such spines, and that seems to be the general character of the shells that are recognised as belonging to that species. Hence we may certainly conclude that our shell is not $A$. concentrica, but some species of the sub-genus Cleiothyris to which $A$. Royssii belongs.

From the great distortion of the specimens, and their preservation only as moulds, it is not easy to compare it with Carboniferous examples of $A$. Royssii. It seems, perhaps, to differ in the spines being generally smaller, and the striæ being more numerous and becoming more crowded marginally; but it evidently itself varies in these points, and $A$. Royssii must have been equally variable, as Davidson says that he has counted eighty striæ on a moderately sized specimen, whereas those he figured must have had fewer. The figure of the Irish A. depressa, M'Coy, which Davidson identifies with $A$. Royssii, appears almost exactly like our shells; and Gosselet records A. Royssii from the Famennian of Belgium, with which Dr. Barrois, in his visit to Devonshire last summer (1896), classed the Pilton Beds. Therefore, though I formerly thought that the larger specimens of our shells might be distinguished, I feel now no difficulty in regarding them as A. Royssii, though possibly they may prove to be a local variety of it.

Affinities.-Athyris reticulata, Gosselet, ${ }^{1}$ is said to be distinguished from A. Royssii by its smaller size, and by its width being greater than its length. In these respects it may not differ from our shell, but it may perhaps have had a stronger and more angular fold.

\section{Genus-SPIRIfera, Sowerby, 1815.}

1. Spirifera miorogemma, Phillips. Plate XVIII, figs. 7,7 a, 8 .

1841. Spirifera microgemma, Phillips. Pal. Foss., p. 68, pl. xxvii, figs. $116 a, b$. 1864. - ineata?, Davidson (pars). Brit. Foss. Brach., rol. iii, p. 43, pl. iv, fig. 16 (only).

1882. - - - - Ibid., vol. v, p. 32, pl. ii, figs. 5, 5 a.

1896. - - Whidborne. Proc. Geol. Assoc., vol. xir, p. 375.

Localities.-In the Porter Collection are six specimens from Pilton and one from Roborough ; in the Barnstaple Athenæum two from Upcott, one from Top Orchard, and one from Vicarage Well; in the Woodwardian Museum one from Barnstaple.

Remarks.-Davidson seemed inclined to regard Sp. microgemma, Phillips, as . 1 1877, Gosselet, 'Ann. Soc. Géol. Nord,' vol. iv, p. 312, pl, iii, fig. 3. 
identical with Sp. lineata, Martin, sp., but left the question undecided. Under $S p$. lineata he included as varieties $S p$. elliptica, Phillips, ${ }^{1}$ and $S p$. imbricata, Sowerby, ${ }^{2}$ sp., but afterwards separated the latter on account of the different shape of its spirals. An examination of a large series of Carboniferous specimens of the above shells shows that in them the fold and sinus are generally absent, are very rarely clearly marked, and never deflect the transverse ridges. Waagen concludes from Davidson's description that dental plates are absent, though they are certainly mentioned by $\mathrm{M}^{\circ} \mathrm{Coy} .^{3}$

Our Pilton specimens are with two exceptions much distorted, and none show the ornament except under the aspect of a mould. They all have definite signs of a fold and sinus, which frequently deflect the transverse striæ; their transverse ridges are few and coarse, being not more than fifteen or twenty; their spines are just visible to the naked eye. One cast shows short but evident arching dental plates. In another the spines are seen to be bicanaliculate (as described by Davidson in a Carboniferous shell). Those specimens which seem to be least distorted are slightly transverse, and the curvature of the front margins somewhat approaches a semicircle. Hence it appears that they constitute a form which does not seem to vary much, and which differs considerably from the general run of Carboniferous forms, but most nearly approaches $S p$. imbricata. Whether the difference should be regarded as of specific or only varietal value remains yet to be decided; but if $S p$. imbricata be distinct from $S p$. lineata, the presumption is that the present form is equally distinguishable from each of them, and therefore it seems preferable to resume, at least provisionally, Phillips's specific name.

2. Spirifera Verneullit, Murchison. Plate XVIII, figs. 9-13 a.

1840. Spirifer Vernedili, Murchison. Bull. Soc. Géol. Fr., vol. xi, p. 252, pl. ii, figs. $3 a-e$.

1840. - Lonsdalir, MLurchison. Ibid., p. 251, pl. ii, figs. $2 a-c$.

1840. - Archiaci, Murchison. Ibid., p. 252, pl. ii, figs. 4a-c.

1858. - - Pacht. Baer and Helmeren's Beitr. Russ. Reiches, Band xxi, p. 95.

1864. Spirifera disjuncta, Davidson. Brit. Foss. Brach., vol. iii, p. 23, pl. v, figs. $1-12$; and pl. vi, figs. $1-5$.

1S68. Spirifer Disudxctus, Dames. Zeitsch. Deutsch. Geol. Gesell., vol. xx, p. 494 .

1 1836, Phillips, 'Geol. Yorks.,' pt. 2, p. 219, pl. x, fig. 16.

2 1822, Sowerby, 'Min. Conch.,' vol. iv, pl. cecxxxiv, fig. 3.

3 1855, M‘Coy, 'Brit. Pal. Foss.'’ p. 429. 
1871. Spirifer Verneuilt, Kayser. Ibid., vol. xxiii, p. 587.

1851. Spiriferd Verneuilit, Davidson. Brit. Foss. Brach., vol. iv, p. 339, pl. xxxviii, figs. 9-14.

1882. - $\quad$ - $\quad$ - $\quad$ Ibid., vol. v, p. 35, pl, ii, fig. 1.

1852. Spirifer Verneuilt, Barrois. Mém. Soc. Géol. Nord, vol. ii, p. 257, pl. x, figs. $7 a-d$.

18s6. - Dissunctus, ${ }^{1}$ Wenjukoff. Fauna Dev. Sist. N.-W. und Cent. Russl., p. 64, pl. iii, figs. 1-7; and pl. iv, figs. $1-4$.

1894. - Verveuili, Gosselet. Mém. Soc. Géol. Nord, vol. iv, p. 1, pls. i-v ; pl. vi, figs. 58, 59.

1894. - Disunctus, Hall and Olarke. Pal. N. Y., vul. viii, pt. 2, p. 24.

Localities.-Pilton, Ashford Strand, Orchard House Pilton, Goodleigh, T'op Orchard, Croyde Bay, Tutshill, Roborough, Shirwell, Saunton, Braunton, Bradiford, Hagley Bridge, one mile south of Wiveliscombe, Luscott Barton, Poleshill, Kingdon's Shirwell, Laticosta Cave Croyde, Upcott Arch, Pouch Bridge, Rock Inn Quarry (near Wiveliscombe), Camelford, Tintagel, South Petherwyn. It is one of the most frequent Brachiopods of the Pilton Beds. In the Woodwardian Museum is a specimen from the Lingula-zone of Sloly.

Size.-The largest specimen I have seen is more than eight inches in width.

Remarles.-Davidson regarded all the Spirifers from the Pilton Beds, which have numerous plaits on the fold, as belonging to Sp. Vernenilii, with which he united Sp. Archiaci, Lonsdalii, Murchisoniana, ${ }^{2}$ and Barumensis, as well as the various forms described by Phillips and by Sowerby from these beds. More lately, however, he appears to have expressed an opinion that Sp. Barumensis was distinct. It would appear that he was at one time inclined not only to separate Sp. Murchisoniana specifically, but to refer it to Cyrtia, a genus which afterwards he declined to recognise.

Sp. Verneuilii is defined by Gosselet as covered with numerous fine ribs from margin to beak, those of the fold and sinus bifurcating, but those of the wings being always simple (and thereby differing from Sp. striata). On the latter character he lays much stress, stating that among Belgian species it is only shared by $S p$. Orbeliana, which he distinguishes by the slightly convex centre of its sinus and the trapezoidal form of its "languette." Sp. aperturata, Schlotheim, he defines as having the lateral ribs narrower than the intervening furrows, and occasionally though rarely bifurcating.

Whether our Pilton fossils all belong to the present species is a question by no means easy to decide. Being almost always distorted and imperfectly preserved, it is most difficult to say whether any lines of distinction can be drawn between

1 Grouped with Sp. Verneuili, Sp. Archiaci, Sp. tenticulum, and Sp. Brodi.

2 1845, Murchison, von Keyserling, and de Verneuil, 'Geol. Russia,' vol.ii, p. 160, pl.4, fige. 1 a-d. 
the multitudinous examples preserved in different collections, though they evidently vary very greatly. Three lines of variation are apparent in them. (1) The area is sometimes narrow and concave, as in the type ; and sometimes extremely broad and flat, as in the form Sp. Barumensis, Salter, MS., of which examples are found in which the area is much higher than wide, and the umbo hardly if at all incurved. (2) The dental plates are sometimes short and sometimes extremely large and massive, extending almost to the front of the ventral valve. (3) The minute ornament of the shell (which is rarely preserved) is seen sometimes (in specimens from Ashford Strand) to be fine transverse lines, sometimes (in specimens from Ashford Strand) fine longitudinal lines, and sometimes (in specimens from Snapper Quarry) coarse, concentric, irregularly arching rows of pores. It appeared to me at one time that these variations might indicate specific differences, but the examination of foreign specimens does not seem to support this idea.

With regard to the first point, the very numerous figures given by Gosselet show very great variation in the size of the area, though perhaps hardly as great as is seen in the North Devon shells. Moreover in the latter I observe that there does not seem any distinct demarcation to be drawn between shells with narrow areas and those with broad, and that both varieties occur of all sizes. In none of our specimens have I seen any indication of a foramen.

With regard to the second point, the dental plates appear to be most developed in large shells with broad areas, but in smaller specimens with broad areas they are sometimes very short; while Davidson has figured a small specimen with a narrow area from Budleigh Salterton in which these plates are exceedingly developed. It is to be noted that Hall describes them as being inconsiderable in his Aperturati-group (which includes $S p$. Verneuilii) except in a few shells, which he separates from the "disjunctus-type" under the name of the "Hungerfordi-type." He, however, states them to be very differently developed in shells of adjacent external form.

With regard to the third point, at first sight it appears to be impossible to reconcile the three variations of minute ornament given above. Davidson states that the surface is covered by numerous fine contiguous concentric lines. Gosselet figures one specimen with similar concentric lines, while he figures Cyrtia Murchisoniana with fine longitudinal lines. In our specimens I find that these two classes of ornament certainly occur together, though where one is prominent the other is almost obliterated. Few of the Continental specimens $\mathrm{I}$ have examined show the minute characters. In specimens of Sp. Lonsclalii three coarse longitudinal lines are seen on each rib, as originally described; and in Murchison, von Keyserling, and de Verneuil's 'Russia,' a specimen of Sp. Archiaci is figured with an irregular spinous ornament. But in the British Museum is a very large series of Spirifers from China, some of which are referred to Sp. Verneuitii (one being so labelled in the Davidson Collection, along with a specimen exactly 
similar in ornament from Chimay, in Belgium), while others are referred to Cyrtia Murchisoniana (one of these being the figured Chinese specimen ${ }^{1}$ of it). While the extreme forms of these shells seem perfectly distinct, I have failed to find any definite line of specific division between them. Though they vary much in shape, some being longer, more ovoid shells, and having a shorter linge-line than any European forms, they may be traced without break into the ordinary forms of the shell, and even on to those alate forms with produced wings. Their styles of minute ornament, which is often perfectly preserved, are not constant to particular shapes, though in the elongate form, in which a foramen is sometimes seen, this minor ornament generally consists of fine longitudinal threads, and in the broad form generally of transverse lines or of coarser longitudinal threads irregularly broken into spines,_-similar, in fact, to the Russian figure,-and thus approaches the texture seen in our specimens from Snapper Quarry. In the Museum of Practical Geology is a specimen from South Petherwyn with the same structure as these Snapper specimens, which have narrow areas. That shell has a large flattish receding area, and a slightly incurved umbo, and evidently falls within the variety Sp. Barumensis. Lastly, in the Woodwardian Museum is a slab from South Petherwyn, with three specimens, which show transverse rows of punctations with a tendency to run into longitudinal lines, thus connecting our two figured examples from Ashford and Snapper; and, moreover, the ornament in these three specimens is of three different degrees of coarseness, intermediate between those of the two last-mentioned shells.

It would thus appear-

(1) That the various styles of ornament here described are not inconsistent with each other, and may all belong to Sp. Vernerilii, and consequently that Sp. Verneuilii is as variable in ornament as in shape.

(2) That though it is still possible that more than one species may be included under this name, there is no evidence of this from our Devonshire specimens; even the form Sp. Barumensis, distinctive as it sometimes seems, does not appear to have any definite characters for its separation.

(3) That the variations of $S p$. Verneuilii are remarkably great. It might possibly be described as "a species in process of solution." While I venture to think that the difficulties to certain developments of evolutionary theories which are in vogue at present may ultimately be found to be insurmountable, we may say that if species have changed at all it is probable that there were times when the forces of variation were especially active. Every now and then we meet with a species which is so variable that it seems impossible to say whether it is one or a collection of forms. 'This may be a permanent state, or it may be the crisis in its life-history where it is breaking up into a number of new species. The variations in

1 Daridson, 'Quart. Journ. Geol. Soc.,' vol. ix, 1853, p. 355, pl. xv, figs. 6-9. 
Sp. Verneuilii are so great and intermingled that it may be in that transition stage.

(4) That some of the shapes of $S p$. Vernenilii might from external ornament be placed under the genus Cyrtia. What is known of the internal arrangements of these shells does not separate them from Spirifera, and the size and flatness of their area are certainly not a sufficient reason for doing so. What, therefore, the genus Cyrtia may be worth must depend on structures not seen in our English specimens. These shells also resemble some species of Syringothyris-e.g. S. cuspidata-externally, but distinctly differ from them internally.

3. Spirifera obli'terat'a, Phillips. Plate XIX, figs. $1-4 a$.

? 1840. Spirifer Bouchardi, Murchison. Bull. Soc. Géol. Fr., vol. xi, p. 253, pl. ii, figs. $5 a-c$.

1841. Spirifera obliterata, Phillips. Pal. Foss., p. 78, pl. xxxi, fig. 135.

1896. - - Whidborne. Proc. Geol. Assoc., vol. xiv, p. 376.

Description.-Shell very transverse, fusiform, alate. Hinge-line very long, marked in the cast with crenulations. Cardinal angles very acute. Beak small, incurved. Ventral valve with a narrow sinus, bisected by an elevated line, and dorsal valve with a low narrow fold bisected by a median groove. Dental plates short. Lateral ribs low, rounded, five or more in number (sometimes numerous), gradually decreasing in size, and becoming faint or evanescent on the wings. Ovarian area strongly pitted.

Size.-Height of dorsal valve $9 \mathrm{~mm}$. ; width $26 \mathrm{~mm}$.

Localities.--In the Museum of Practical Geology is Phillips's type specimen of Sp. obliterata from Brushford; in the Barnstaple Athenæum is a specimen from 'Top Orchard; in Mr. Hamling's Collection one from Top Orchard; in my Collection four from Ashhill Quarry near Brushford, and two from near the Kiln, Croyde Bay.

Remarks.-Phillips's specimen, being on a slab with other fossils, was unobserved at the time that Davidson described the Devonian Brachiopoda. It has since been recognised, and proves to belong to a definite species of which several other examples have occurred in the Pilton Beds. This specimen is in poor condition, and may perhaps have been slightly shortened by pressure. 'The usual shape of the species appears to be still more transverse. It seems to be distinguished by its small, narrow, undefined fold and sinus, and by its low rounded ribs, which seem to vary considerably in number, to be broad and prominent near the centre, and to diminish rapidly and regularly toward the sides, so that the wings sometimes appear almost smooth. The fold is very undefined; 
it is difficult to say from our specimens how many of the central ribs should be counted as belonging to it.

I am inclined to think it possible that this form may be only a variety of $S p$. Bouchardi, Murchison. In Murchison's figure the ribs seem stronger and more numerous (those on each side of the sinus being very strong), and the transverse lineation stronger and more regular. These slight differences may, however, partly be explained by the better state of preservation of Murchison's specimen. Moreover our Devonshire shells, none of which are sufficiently well preserved to show the transverse ornament clearly, display much variation in the number of the ribs and other points. On the other hand, specimens of Sp. Bouchardi from Ferques in the Davidson Collection are less like them, and all appear to differ in their more angular shape, their definite folds, and their very strong lineations.

Phillips regarded $S p$. obliterata as allied to $S p$. speciosa, Schlotheim $;^{1}$ but Dr. Barrois, to whom I have shown a photograph of it, sees no reason for supposing it identical. It seems to be distinguished from that species, and from its ally or variety $S p$. paradoxa, Schlotheim, ${ }^{2}$ by the bifurcation of its fold and sinus, and the more definite grading of its ribs.

$S p$. mucronata, Conrad, as given by Sandberger, ${ }^{3}$ and $\$$ sp. phalæna, Sandberger, ${ }^{4}$ seem to be less transverse, and to have stronger and more equal ribs.

4. Spirifera (Mar'tinia ?) Unit, Fleming. Plate XIX, figs. 5-7.

1828. Spirifera Urit, Fleming. Brit. Anim., p. 376.

1840. Atripa unguiculus, Sowerby. Geol. Trans., ser. 2, vol. v, pt. 3, pl. liv, fig. 8 .

1841. Spirifera ungiuiculus, Phillips. Pal. Foss., p. 69, pl. xxviii, figs. $119 a-f$.

1864. - UrII, Davidson. Brit. Foss. Brach., vol. iii, p. 41, pl. iv, figs. 25-28.

1884. - (Martinia?) Urit, Davidson. Brit. Foss. Brach., vol. $v_{\text {, }}$ p. 418.

Localities.-Croyde, Braunton, Petherwyn, Top Orchard, Bradiford, Vicarage Well Pilton, Frankmarsh, Upcott Arch Quarry, Ashbill Quarry, Wrafton Lane, \&c. Size.-Height about $9 \mathrm{~mm}$.; width about $13 \mathrm{~mm}$.

Remarlss.-This is a very common and characteristic species. From Devon-

1 1813, Schlotheim, 'Taschenbuch f. Mineral.,' vol. vii, p. 52, pl. ii, fig. 9.

2 Ibid., p. 28, pl. ii, fig. 6.

3 1889, F. Sandberger, 'Entw. Unter-Abtheil. Der. Systems Nassau,' p. 104, pl. iii, fig. 2.

4 Ibid., p. 105, pl. iii, figs. 3, $3 a$. 
shire it was first described under the name Atrypa unguiculus, Sowerby, but was united to the Carboniferous Sp. Urii by Davidson, and no doubt correctly so.

The muscle-scars seen in some of our specimens are long and very narrow, and there are no dental plates or median septum. Thus they appear to fall within the group Martinia, to which Davidson doubtfully referred them, though they certainly bear in some aspects a resemblance to Ambocelia, the value of which cannot be measured until the spires are discovered. None of our specimens show the surface, but Davidson has figured a Carboniferous example with numerous coarse spines.

In size the Devonian fossils somewhat exceed the dimensions of the Carboniferous shell as given by Davidson.

Affinities. -This species seems widely different from the Lummaton Sp. infima, mihi, ${ }^{1}$ which I suspect belongs to Amboccelia.

I think also that Holzapfel ${ }^{2}$ is right in separating it from $S_{p} p$. inflata, Schnur, ${ }^{3}$ which was joined with it by Kayser ; ${ }^{4}$ though my strong impression is that both the shells he figures under that name should be referred to other species.

5. Spirifera mesomala, Phillips. Plate XIX, figs, 8,9 ? $9 a$ ? $9 b$ ?

1841. Spirifera mesomata, Phillips. Pal. Foss., p. 78, pl. xxxi, fig. 137.

Description.-Shell small, moderately transverse, with apparently rounded wings. Beak moderately elevated and incurved. Ventral sinus wide, concave, with two or three indistinct lineations, not breaking. its smoothness. Lateral ribs simple, prominent, rounded, distant, about ten on each side; without signs of transverse markings.

Size.-A specimen measures about $6 \mathrm{~mm}$. wide.

Locality.-One specimen is in my Collection from Saunton Hotel, and one or two in Mr. Hamling's Collection from Snapper Quarry. A very imperfect specimen in Mr. Upfield Green's Collection from Sloly may belong to this species, but $i_{s}$ perhaps more likely to be a small worn example of $S p$. Verneuilii, var. Barumensis.

Remarlis.-Phillips's description of his species is so incomplete that Davidson,

1 1893, Whidborne, 'Dev. Fauna,' vol. ii, p. 108, pl. xiii, figs. 1-3.

2 1895, Holzapfel, 'Abh. k. Preuss. Geol. Landes.,' n. s., pt. 16, p. 253, pl. xi, fig. 20 (?); and pl. svii, fig. 6 .

3 1854, Schnur, 'Palæontographica,' vol. iii, p. 211, pl. xxxvii, fig. 2.

4 1871, Kayser, 'Zeitsch. Deutsch. Geol. Gesell.,' vol. xxiii, p. 584. 
not having seen an example of it, simply quoted it on Phillips's authority without expressing an opinion upon its specific value. It may prove to be only the young form of Sp. Verneuilii.

I have found two or three small shells which seem likely to be the same species as Phillips's, but they are insufficient to give decided evidence on the question.

The small specimen (fig. 8) from Saunton has certainly a distinctive appearance. It is a ventral valve, and looks as though it would accurately correspond with Phillips's figure of the dorsal valve.

\section{Genus-Spiriferixa, d'Orbigny, 1847.}

1. Spiriferina cristata (Schlotheim), var. octoplicata, Sowerby. Plate XIX, figs. 10, $11,11 a$.

1858. Spiriferina cristata, var. octoplicata, Davidson. Brit. Foss. Brach., vol. ii, pt. 4, p. 38, pl. vii, figs. $37-47$.

1864. - - _ - Davidson. ${ }^{1}$ Ibid., vol. iii, p.46, pl. vi, figs. 11-15.

1895. -- $\quad$ - $\quad$ - $\quad$ - $\quad$ Whidborne. Proc. Geol. Assoc., vol. xiv, p. 376 .

Localities.-In the Barnstaple Athenæum are specimens from Ashford Strand; in the Porter Collection from Poleshill and Pilton; in Mr. Hamling's Collection from near the Kiln, Croyde; and in my Collection from East Anstey Station, Ashford Strand, and Pouch Bridge.

Size.-A specimen measures about $21 \mathrm{~mm}$. wide.

Remarls. - This is certainly the species which Davidson figured from Looe and recorded from Pilton, and it has therefore an extensive vertical range in the Devonian rocks. It is a well-characterised form. It is very transverse, with a narrow area, a much incurved beak, numerous (eleven to twenty-one) strong deep ribs, strong, regular, distant transverse lines or flounces, and a very coarsely punctated shell-structure. These puncta seem sometimes to lie in lines corresponding with the transverse lineations. Its fold and sinus are narrow and flattened, and have respectively'a very slight median furrow and rib. In the

${ }^{1}$ In the heading of the species Daridson omits the name octoplicata, but supplies it at p. 123 and in the plates. Though the same divergence occurs in the lists in his last volume, it seems clear that the omission was purely accidental. 
ventral valve there appears to be a median septum, which, taken together with the punctated surface, indicates that it belongs to Spiriferina.

The present shell is the Devonian representative of the race which includes the Silurian Sp. elevata, Dalman, ${ }^{1}$ sp., and the Carboniferous and Permian Sp. cristata (and its variety octoplicata).

As given by Davidson, $S p$. elevata has a much wider area and a less incurved beak, $S p$. sulcata ${ }^{2}$ fewer ribs and sometimes sharper wings, and $S p$. crispa ${ }^{3}$ closer transverse lines and fewer ribs. These forms Davidson does not refer to Spiriferina, but retains in Spirifera.

On the other hand, I can see no differences whatsoever between it and his Carboniferous figures of $S p$. cristata, var. octoplicata, except that the ribs seem slightly less numerous, and a minute median depression is seen on the fold. The small rib on the sinus is equally visible both in the Carboniferous and the Devonian shells. The Permian Sp. cristata ${ }^{4}$ itself has fewer ribs and a more lofty umbo. Thus it seems that the present shell is inseparable from the Carboniferous form, whatever may be its relation to the Silurian and the Permian species.

Affinities.-Sp. Zeilleri, Barrois, ${ }^{5}$ closely resembles it, and may possibly even prove identical; but its lamellæ seem fewer, and its fold not biplicated.

In $S p$. aculeata, Schnur, ${ }^{6}$ the transverse lines seem broken into long fringes instead of simply showing puncta. With regard to that shell it may be noted that Holzapfel ${ }^{7}$ places Spiriferina insculpta, Phillips, sp., as a synonym of it, so far as regards the Devonian form described by Davidson ${ }^{8}$ from Lummaton. Whether this Lummaton shell is separable from the Carboniferous type of Sp. insculpta, and whether it possesses the distinctive longitudinal lineation which exists on the lamellæ of $S p$. aculeata, are questions I venture to think are not yet proved in the affirmative; but in any case two points have been overlooked by Herr Holzapfel, viz. (1) that the Lummaton species is a Spiriferina, not a Spirifera; and (2) that if it is not Sp. insculpta, Phillips, it certainly is Sp. pulchella, Sowerby. ${ }^{9}$ The latter point appears clearly on the examination of Sowerby's type in the museum of the Geological Society. If, therefore, Herr Holzapfel is right in

1 1867, Davidson, 'Brit. Foss. Brach.,' vol. iii, pt. 7, p. 95, pl. x, figs. 7-11.

2 Ibid., vol. iii, pt. 7, p. 91, pl. x, figs. 4-6.

3 Ibid., vol. iii, pt. 7, p. 97, pl. x, figs. 13-15.

4 1858, ibid., vol. ii, p. 17 , pl. i, figs. $37-40,45,46$; - and pl. ii, figs. $43-45$.

¿ 18s2, Barrois, 'Mén. Soc. Géol. Nord,' vol. ii, p. 256, figs. 13, $13 a, 13 b$.

6 1854, Schnur, 'Palæontographica,' vol. iii, p. 203, pl. xxxiv, figs. $2 a, b$.

7 1895, Holzapfel, ‘Abhandl. k. Preuss. Geol, Landes.', n. s., pt. 16, p. 250.

8 Holzapfel quotes Daridson thus:-“1864, Spirifer insculptus, 'Brit. Dev. Brach.,' Supplement, pl. i, fig. 32." This reference requires to be thus corrected:- "1882, Spiriferina insculpta, 'Brit. Dev. Brach.,' Supplement, pl. i, fig. 32."

9 1840, Sowerby, 'Geol. Trans.,' ser. 2, vol. v, pt. 3, pl. lvii, fig. 8. 
this matter, he has unconsciously proved that $S p$. aculeata, Schnur, is a synonym of Spiriferina pulchella, Sowerby, sp.

\section{Family-RhYNCHONellide, d'Orbigny, 1847.}

1. Genus-Rhinchonelia, Fischer de Waldheim, 1809.

Sub-genus-Camarotechia, Hall and Clarke, 1894.

1. Rhynchonella (Camarotechia) Partridgia, Whidborne. Plate XIX, figs. 12-14.

1841. Terebratula Pleurodon?, Phillips (pars). Pal. Foss. (not Geol. Yorks.),

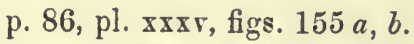

1865. Rhynohonela pledrodon, Davidson (pars). Mon. Brit. Foss. Brach., rol. iii, p. 62, pl. xiii, figs. $12,13$.

1896. - Partridait, Whidborne. Proc. Geol. Assne., vol. xiv, p. 376.

Description.-Shell generally rather small, transversely oval or sub-pentagonal, apparently becoming more transverse with age. Ribs strong, elevated, acutely triangular, reaching to the umbones, and deeply.interlocking at the margins, separated by furrows. Ventral valve with a rather elevated and erect sharp beak, and a sinus which becomes deep in front, so that the "languette" forms a low subtetrahedron. Ribs, three on the sinus and about seven on the sides. Lateral ribs with a slightly concave sweep, and terminating marginally with a sharp angle. Dental plates oblique, reaching about one-third down from the beak, their front ends being joined by a low curved ridge which defines the muscular impressions. Dorsal valve with a flat and straight median fold, becoming prominent in front and sharply angulated at the margin, containing almost invariably four ribs. Sides dilate and drooping. Median septum reaching nearly half-way to the front, and having at its posterior end diverging branches which support the dental sockets (?), which are crenulated exteriorly.

Size.-Some specimens are more than $24 \mathrm{~mm}$. wide.

Localities.-Pilton Vicarage Well, Poleshill, Top Orchard, Roborough, Goodleigh, Raleigh, Bradiford, Frankmarsh, Collar Bridge, Kingdon's Shirwell, Saunton, Croyde Bay, Laticosta Cave, Ashford Strand, Upcott Arch Quarry, Ashhill Quarry, Pouch Bridge, Fremington, \&c.

Remarles. -This species is abundant and wide-spread in the Pilton Beds, but being usually crushed, contorted, or fragmentary, its exact characters are not easy to define. In writing of it Phillips specially remarks on the difficulty of deciding, 
in so complicated a genus, the species of shells which are in such a poor state of preservation, and doubtfully refers them to his Carboniferous Rh. pleurodon. ${ }^{1}$ In this he has been followed by Davidson and others; but it seems probable that there are sufficient grounds for distinguishing them from the Carboniferous shell, even in their defective state. Rh. pleurodon generally has five ribs on the fold, though they may vary from three to nine. From the study of a large number of specimens of our Pilton shell I find that they have almost invariably four ribs on the fold with three on the sinus. Gosselet lays great stress on the number of ribs on the fold, using it as a distinguishing character for his various Upper Devouian species; and, if his view of its importance is correct, we have here a sufficiently definite specific distinction; for, even granting that in many species of Rhynchonella the number of ribs on the fold is very various, there seems no reason why in other cases their definite number should not be a point of specific importance. Moreover, the profile of the present shell seems much less rounded than that of Rh. pleurodon; the front of the median ribs of the dorsal valve and of the lateral ribs of the ventral valve sweeping definitely outwards till they are abruptly turned in at the margin at a sharp angle, more in the manner of $R h$. anisodonta than of Rh. pleurodon.

Our shells occur as casts, and as I have only seen specimens of the true Rh. pleurodon retaining the shell, I have been unable to compare the interior, the arrangements of which are well indicated in our fossils. These arrangements appear exactly the same as those by which Hall and Clarke ${ }^{2}$ define their genus Camarotochia, to which they refer Gosselet's Upper Devonian species, though they do not indicate whether they also include in it Rh. pleurodon.

While, however, there seem to be sufficient grounds for distinguishing $R h$. Partridgix from $R$ h. pleurodon, their relationship is probably very close, the forme! being apparently somewhat more specialised than the latter. One point of agreement which may be noted is the slight median channeling of the lateral ribs, which is often seen in the Pilton shells, and is mentioned by Davidson as a character of Rh. pleurodon.

Affinities.-None of the Upper Devonian Rhynchonellæ described by Gosselet ${ }^{3}$ in 1887 appear to correspond with our species. While several have the same number of median ribs, they all (as well as $R h$. Daleidensis, F. Römer, ${ }^{4}$ or $R h$. inaurita, Sandberger ${ }^{5}$ ) differ in their more rounded profile and the less acutely produced sweep of their medio-dorsal and latero-ventral ribs.

1 1836, Phillips, 'Geol. Yorks.,' vol. ii, p. 222, pl. xii, figs. 25-30.

2 1894, Hall and Clarke, 'Pal. N. Y.,' vol. viii, pt. 2, p. 189.

3 1887, Gosselet, 'Ann. Soc. Géol. Nord.,' vol. xiv, p. 188.

4 1844, F. Römer, 'Rhein. Uebergangsgeb.' p. 65, pl. i, figs. $7 a-c$.

5 1556, Saudberger, 'Verst. Rhein. Nassau,' p. 337, pl. xxxiii, figs. 5-5 c. 
2. Rhynchonelia (Camarotechia) togata, n. sp. Plate XIX, figs. 15-18.

? ? 1841. Spirifer rudis, Phillips. Pal. Foss., p. 78, pl. xxxi, figs. $136 a-c$.

1896. Camarotcecha ${ }^{1}$ togata, Whidborne. Proc. Geol. Assoc., rol. xiv, p. 376.

Description. - Shell very large, subtrigonal, hardly (if at all) wider than long. Beak apparently elevated, acute, and only moderately incurved. Ventral valve with a broad subtrigonal sinus, becoming deep in front and bearing two strong median ribs; and with four ribs on each side, of which the first is very strong and the others are successively less distinct. Dental plates (which may be sometimes absorbed?) short, diverging. Muscular area strongly impressed. Dorsal valve with three ribs on the fold, with a short median septum (less than a quarter of the total length) divided into branches posteriorly, supporting an incipient spondylium, and with strongly crenulated outer socket-walls.

Size.-Length and width about $33 \mathrm{~mm}$.

Localities. - In the Porter Collection are two specimens from Pilton and one from Roborough ; in the Barnstaple Athenæum one from Pilton; in the Museum of Practical Geology four, labelled North Devon, Marwood, Braunton, and Barnstaple. I have recognised it at Ashbill Quarry.

Remarks.-Though this species appears well characterised, our specimens are all too fragmentary and crushed to permit its full definition. Of them five are ventral and three dorsal valves; and in the latter the indications of lateral ribs are obscure, probably in part on account of the crushing of the shell, whereas in the former they are very strong and definite.

With regard to its generic position, a careful comparison of our specimens with the figures given by $\mathrm{Hall}^{2}$ of his group Camarotochia shows that in all points of structure it falls well within its limits.

- It is not impossible that this may be the same shell as Spirifera rudis, Phillips. His types appear to be lost, and he gives practically no description. His three figures are so "rude" that they may be regarded as unidentifiable, but one of them is very like a dorsal valve of this species. Probably, if our shells were trimmed down, fragmentary specimens could be produced which would agree with all three of his drawings, though possibly the same effect might be produced by trimming other shells in a similar manner. At all events Phillips's species is too ambiguous for any identification with it to be safe.

I have examined the type of $R h$. subdentata, Sowerby, ${ }^{3}$ in the Woodwardian

$1 \mathrm{By}$ a clerical error this word was printed Camarella in my list.

2 1894, Hall and Clarke, 'Pal. N. Y.,' vol. viii, pt. 2, pl. lvii, figs. 15-32, 49.

3 1840, Sowerby, 'Geol. Trans.,' ser. 2, vol. r, pt. 3, pl. liv, fig. 7. 
Museum. It evidently belongs to the same species as the specimen which Phillips ${ }^{1}$ refers to it, but which Davidson ${ }^{2}$ unites with Rh.reniformis, Sowerby, only differing from it by the possession of a low arching fold. On the other hand, the second Devonian specimen figured as Rh. reniformis by Davidson ${ }^{3}$ appears more likely to belong to Rh. Phillipsii, Davidson. ${ }^{4}$ From the present form all these specimens differ by their wide and nearly straight hinge-lines, and by the character of their folds. Whether, therefore, Rh. subdentata be a synonym of Rh. reniformis or not, it is certain that the present species is distinct from both.

3. Rhrnchonelia iaticosta, Phillips, sp. Plate XX, figs. $3,3 a, 4$.

1841. Terebratula laticosta, Phillips. Pal. Foss., p. 85, pl. xxxiv, fig. 153.

1865. Rhincionelda taticosta, Davidson. Brit. Foss. Brach., vol. iii, p. 61, pl. xiv, figs. 1-3.

Locality.-It occurs abundantly in a bed about 1 foot thick, which is exposed in a small cave under the cliff near the wall that bounds the south side of Baggy promontory. It is represented in the various collections by specinens which are always defective and contorted.

Size.-A specimen measures $40 \mathrm{~mm}$. wide.

Remarks.-Of this handsome and distinct species I have unfortunately been unable to obtain any specimens that will yield a satisfactory figure. Its beak appears to be prominent and only moderately incurved, and to have long dental plates. The fold and sinus seem low, rounded, and not strongly defined, with five or six ribs on the former, and four or five in the latter. The ribs are strong, and reach quite to the umbo, but appear rounded and not much elevated. In the dorsal valve is a median septum reaching about halfway forwards. The margins of the valves are rounded in.

Affinities.-It appears widely different from our other Devonian species.

Rh. Pengelliana, Davidson, ${ }^{5}$ from Looe, is still larger, and has more ribs on the fold. The Carboniferous $R / l$.? Carringtoniana, Davidson, ${ }^{6}$ has feebler and more numerous ribs.

1 1841, Phillips, 'Pal. Foss., p. 90, pl. xxxv, fig. 164.

${ }^{2}$ 1865, Daridson, 'Brit. Foss. Brach.,' vol. iii, p. 62, pl. xiii, fig. 7.

${ }^{3}$ Ibid., fig. 6.

4 1882, Davidson, ibid., vol. v, p. 43, pl. ii, fig. 14.

5 1865, Davidson, ibid., vol. iii, p. 61, pl. xii, figs. $8,9$.

6 1863 , ibid., vol. ii, pt. 5, p. 227, pl. xxiii, fig. 22 ; and pl. liii, figs. $1,2$. 


\section{Family-STrophomenide, King, 1846.}

1. Genus-Or'ris, Dalman, 1828.

1. Orthis interlineata, Sowerby. Plate XX, figs. 6, 7 .

1840. Orthis Interlineata, Sowerby. Geol. Trans., ser. 2, vol. v, pt. 3, pl. liii, fig. 11 ; and pl. liv, fig. 14.

1810. - plcata, Sowerby. Ibid., pl. liii, fig. 10.

1841. - interlineata, Phillips (pars). Pal. Foss., p. 63, pl. xxvi, figs. $106 a, b$ (only).

1841. - Parallela, Phillips. Ibid., p. 64, pl. xxvi, fig. $109 a-d$.

1865. - interlineata, Davidson. Brit. Foss. Brach., vol. iii, p. 91, pl. xvii, figs. 18-23.

Localities.-This shell is common and wide-spread. It occurs at Top Orchard, Bradiford, Kingdon's Shirwell, Upcott, Braunton, Pilton, Wrafton Lane, Saunton Point, Frankmarsh, Ashbill Quarry, Croyde, Petherwyn, and Landlake.

Size.-Height $12 \mathrm{~mm}$., width $16 \mathrm{~mm}$.

Remarlis. - The types of O. interlineata and O. plicata, Sowerby, which are in the nuseum of the Geological Society, evidently belong to the same species. Davidson also remnites with it Orthis parallela, Phillips, which Phillips had separated from it. Orthis orbicularis, var., Murchison ${ }^{1}$ (which Davidson seems to refer to in his description of this species), does not seem distinguishable from it. Murchison, himself, regarded his shell as distinct from the Orthis orbicularis ${ }^{2}$ of the Silurian System, which is united to O. lunata, Sowerby, ${ }^{3}$ by Davidson.

2. Orthis, sp. Plate XX, figs. $8,8 a, 9$.

1841. Orthis interlineata, Phillips (pars). Pal. Foss., p. 63, pl. xxvi, figs. $106 c, d$ (ouly).

? 1841. - Pucata, Phillips (not Sowerby) (pars). Ibid., p. 64, pl. xavi, fig. $108 e$ (only).

Description.-Shell minute, flat. Umbo elevated, prominent, rounded. Hingeline much shorter than the width of the shell. Lateral margins semicircular.

1 1840, Murchison, 'Bull. Soc. Géol. Fr.,' vol. xi, p. 255, pl. ii, figs. $8 a-c$.

2 1839, Sowerby, in Murchison, 'Sil. Syst.,' p. 611, pl. v, fig. 16.

3 Ibid., p. 611, pl. v, fig. 15. 
Front margin gently convex. Valve with a median depression. Surface covered with about twenty strong, distant, alternating ribs, which have the appearance of being microscopically lineated and granulated.

Size.-Height $4 \mathrm{~mm}$., width $5 \mathrm{~mm}$.

Localities.-Two or three specimens are on a slab from Saunton in Miss Partridge's Collection, and its reverse in the Porter Collection. I have, I believe, observed two or three better specimens of this tiny shell, but, failing to take note of them at the time, am now unable to find them.

Remarls.-Phillips figured a specimen which is almost identical witl ours, both in size, shape, and ornament. This he referred to O. interlineata, but it seems to me questionable if our shell be the young of that species, as it seems distinguished not only by the fewness of its ribs, but by the size of its umbo and by several other points. We have not, however, sufficient evidence to enable us to arrive at its true character.

2. Genus-Orthotetes, ${ }^{3}$ Fischer de Waldheim, 1830.

1. Orthotetes crenistria (Phillips), var. arachnoldea, Phillips. Plate XX, figs. 10,11 .

1836. Spirifer arachioideus, Phillips. Geol. Yorks., vol. ii, p. 220, pl. xi, fig. 4.

? 1841. Orthis semicirculanis, Phillips. Pal. Foss., p. 65, pl. lviii, fig. 112*.

1865. Streptorifychus crenistria et var. arachroideus, Davidson. Brit. Foss. Brach., vol. iii, pt. 5, p. 81 , pl. xviii, figs. 4. 7 .

1896. ОитнотетеS crenistria, Whidborne. Proc. Geol. Assoc., vol. xiv, p. 376.

1 I have to thank Professor Rupert Jones for the trouble be has taken in deciding the orthography of this name. It was originated in 1829 by Fischer de Waldheim (not by Evans) ('Bull. Imp. Soc. Nat. Moscou,' p. 375) for a shell found by Mr. Evans at Pakhrino, which he (i.e. Fischer)

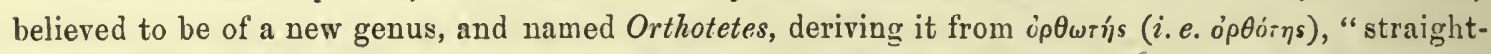
ness," because "at the hinge is a transrerse impressiou straight and linear." "In 1837 ("Oryct. Gouv. Moscou,' p. 133) he repeats the same spelling and deriration, and figures the shell. In 1850 ('Bull. Imp. Soc. Nat. Moscou,' p. 491) he describes and figures it under the same name, and distinguishes it from Orthis.

Professor Rupert Jones writes, "Orthotetes was made wilfully from i $\rho \theta \omega \tau \eta \dot{s}$, and, though irregular, must be accepted as an intended name." Bronn and Davidson wrote it thus ; but later authors, e.g. Zittel, Ehlert (deriving it from óposos), and Hall, changed it to Orthothetes. Orthothetes might be derived from ó $\rho \theta$ is and $\theta \dot{\epsilon} \tau \eta s$, but that would mean "the adoptive father of straight things" (or ? of an Orthis), and would be (even on evolutionary principles) hardly an improvement on Fischer's original malformed word. If altered at all it should have been changed to Orthotes. 
Localities.-Croyde Bay, Saunton Point, Saunton Hotel, Ashford Strand, Upcott Arch Quarry, Bradiford, Poleshill, Kingdon's Shirwell, Paper Mills Ilfracombe Road, Goodleigh, Top Orchard, Pouch Bridge, Rock Inn Quarry neal' Wiveliscombe, Petherwyn. Only moderately common.

Size.-One specimen is more than $50 \mathrm{~mm}$. long and wide.

Remarlis.-Davidson considers that our Pilton fossils show no difference from the Carboniferous species, O. crenistria. It is to be observed, however, that in the typical form of this species three or four smaller ribs often occur between two of the larger, whereas in our specimens the larger and smaller ribs always alternate r'egularly. Our ventral valves, moreover, appear to be usually flat rather than concave. Hence they appear to fall within the variety arachnoidea as given by Davidson, who indeed seems to refer them to that form.

A comparison of our shells with Lummaton specimens of $O$. umbraculum seems to show that the distinction made between them by Davidson can most probably be sustained. While both species are very variable, their ornament seems to differ in character, the ribs of 0 . umbraculum being relatively closer and sometimes differently grouped, while the transverse threads in 0 .crenistria are stronger. I have not, however, seen any Lummaton specimens with the surface sufficiently well preserved to show the minute ornament which Davidson describes as characterising Eifel specimens of that species.

Davidson ${ }^{1}$ regards Orthotetes pecten, Linné, sp., as closely resembling in size and striation some shapes of 0 . umbraculum. These two certainly seem more like each other that they are to 0 . crenistria.

Ehlert, ${ }^{2}$ in a lucid and elaborate dissertation on 0 . hipponyx, Schuur, sp., ${ }^{3}$ refers that shell to the Lower Devonian, O. unnbraculum to the Middle Devonian, O. crenistria, var. devonica, Keyserling, sp., ${ }^{4}$ to the Upper Devonian, and $O$. crenistria to the Carboniferous, as cognate forms. From his description, however, Keyserling's shell does not seem to agree with the Pilton for'm. Davidson states that it has been sometimes referred to $O$. crenistria, var. senilis. ${ }^{5}$

The Pilton shell is in itself very variable in the number and strength of its ribs. A very large variety occasionally occurs ( $\mathrm{Pl}$. XX, fig. 10) in which they are very much finer and more numerous than usual (being sometimes more than 200 ), and in which the ventral valve is definitely concave. This multiplication of ribs may be partly but not entirely due to age. It is interesting to

1 1865, Davidson, ‘ Brit. Foss. Brach.', vol. iii, p. 78 ; and 1871, ibid., pt. 7, p. 306.

2 1897, Ehlert, 'Bull. Soc. Géol. Fr.,' ser. 3, vol. xxiv, p. 856, pl. xxrii, figs. 12-16.

${ }^{3}$ 1851, Schnur, 'Progr. d. h. Bugersch.,' p. 4.

4 1846, Keyserling, "Reise Petschora-Land, Geol. Beobacht.," p. 221, pl. vii, figs. 7-7 c.

5 1865, Davidson, ‘ Brit. Foss. Brach.', vol. iii, p. 80. 
compare this form with Ehlert's figures of 0 . hipponyx, which lies between it and $O$. umbraculum.

3. Genus-Strophomena, de Blainville, 1825.

1. Strophomena Rhombordalis, Wilckens, sp. Plate XX, fig. 5.

1865. Strophomena rhomboidalis, var. analoga, Davidson. Brit. Foss. Brach., vol. iii, p. 76, pl. xv, figs. $15-17$.

1884. - - $\quad$ - Davidson. Ibid., vol. v, p. 467.

1893. - - var. ANaloGa, Whidborne. Der. Fauna, vol. ii, p. 149.

Localities.-This is a moderately common shell in the Pilton Beds, and is represented in most museums. Among the localities are Top Orchard, Pilton, Braunton, Goodleigh Road, Croyde, Poleshill, Pottington, Fremington, Upcott Arch Quarry, Wrafton Lane. It is also found in the Ilfracombe Beds.

Remarks.-Our specimens are often excellently preserved, and include the interiors of both valves as well as the exterior. I can see nothing to distinguish them as a variety; if anything, they are more like the Silurian than the Carboniferous shells. Davidson, in fact, adopted for the typical Silurian form the description he had before given for his Carboniferous variety, and he ultimately dropped the varietal name analoga from the Devonian and Carboniferous shells. Our North Devon specimens certainly support this view.

\section{Family-Produotide, King, 1846. \\ 1. Genus-Productus, Sowerby, 1812.}

1. Produotus Prelongus, Sowerby, sp. Plate XX, figs. 12, $12 a$, 13, 13 a.

1840. Lepteata prelonga, Soverby. Geol. Trans., ser. 2, rol. v, pt. 3, pl. liii, fig. 29.

\lrcorner

1855. Producta premlonga, Mr Coy. Brit. Pal. Foss., p. 390.

1865. Productus prelongus, Davidson. Brit. Foss. Brach., vol. iii, p. 102, pl. xix, figs. $22-25$.

Description.-Ventral valve very elongate, suboval, evenly convex. Hingeline nearly, if not quite, as long as the width of the shell. Umbo extremely large, extending very greatly beyond the hinge, and recurved upon it so that its apex is in its close proximity. Surface with a very narrow, shallow, irregular, 
sinus from the level of the hinge-line to the margin, bearing a longitudinal row of four or five very large spines. Cast ornamented with very numerous, reticulating, longitudinal threads, which show a tendency to group themselves into more or less incipient ribs. Wings with a few coarse tubercles (spines) near the corners.

Dorsal valve transverse, geniculated, with a minute umbo; having (as seen from within) a large elevated triangular ridge down the centre, and seven or eight smaller broken ridges on each side, which increase in size as they cross the flat part of the shell, and extend to the margins; the whole nodulated by rugose transverse undulations, which are minute near the umbo, but soon become very coarse. Ears convex, prominent, marked only with transverse ridges.

Size.-About $35 \mathrm{~mm}$. long and wide.

Localities.-Croyde, Braunton, Saunton, Top Orchard, Kingdon's Shirwell, Ashford Strand, Upcott Arch Quarry, Wrafton Lane, Rock Inn Quarry, Pouch Bridge. It is very abundant, generally gregarious; but it seems local, probably being confined to limited beds, which in the disturbed condition of the Pilton Series it is not easy definitely to trace.

Remarks.-The external surface of this shell does not appear to be known. The ventral valve occurs in a state that shows a coarse ramifying fibrous texture, which has the appearance of having originally been covered by an additional layer of shell. This valve is remarkable for the incipient central keel in the midst of a rather definite shallow groove or sinus, which bears a row of very large and probably long, cylindrical, or slightly clavate spines. There are also a fer coarse spines on the ears. The ribs are rounded and more or less indistinct, and there seem no signs of spines upon them.

The dorsal valve is so dissimilar from the ventral valve in shape and markings that it was regarded by my friend Mr. Townshend Hall as a distinct species; but Sowerby's type, which is in the Woodwardian Museum, preserves both valves in contact, as pointed out by $\mathrm{M}^{\circ} \mathrm{Coy}$, and thus proves their true relationship. On account of its geniculate form it is always its inner face which is exposed, and I have therefore described it from that point of view. If it were seen from the outside its characters would probably be almost exactly reversed.

2. Productus prelongus, Soverby? var. simplioion, n. var. Plate XX, figs. 14, $14 a, 15,15 a$.

1865. Productus longispinus?, Davidson. Brit. Foss. Brach., rol. iii, p. 103, pl. $x x$, fig. 7.

1896. Whidborne. Proc. Geol. Assoc., rol. xiv, p. 376. 
Description.-Ventral valve usually rather small, elongate, gibbose, but flattened on the marginal half of the centre of the valve. Umbo more or less elevated, recurved upon the hinge. Hinge-line shorter than the width of the shell. Surface having (1) from fifteen to twenty-five rather irregular, rounded rays, rising some distance in front of the umbo, and bearing some large, long spines, which tend to arrange themselves in transverse rows; (2) exceedingly minute fibrous markings; and (3) a few irregular transverse undulations on the wings and umbonal parts.

Size.-An unusually large specimen measures $33 \mathrm{~mm}$. long, $20 \mathrm{~mm}$. wide, and $10 \mathrm{~mm}$. deep; its umbo extends about $8 \mathrm{~mm}$. behind the hinge-line.

Localities.-In the Woodwardian Museum are eight specimens from Croyde and three from Top Orchard; in the Musenm of Practical Geology one from Braunton; in the Porter Collection five from Pilton and one from Poleshill; and in the Barnstaple Athenæum a slab containing specimens mentioned and figured by Davidson as "P. longispinus, Sowerby?"

Remarks.-The specimens in the Barnstaple Athenæum, which Davidson referred somewhat doubtfully to $P$. longispinus, are very imperfect and indistinct; but they are evidently identical with the other specimens mentioned above, which are most of them in a better state of preservation, and afford clear proof that they do not belong to the same species as Sowerby's Carboniferous $P$. longispinus. They have much stronger and fewer ribs, and none of them show any signs whatever of an angular median sinus.

From the typical form of $P \cdot p r æ l o n g u s$ they usually differ by (1) their smaller size; (2) the absence of a sinus bearing a vertical row of very long spines; (3) the presence of spines on otber parts of the body, which are often arranged in concentric rows; and (4) their very much more definite and regular ribs.

On the other hand, these points of difference are not constant. One or two of the specimens show a distinct tendency to a slight median groove or concavity, and have median spines arranged longitudinally. It appears to me that it will therefore be best to regard them as a variety of $P$. prælongus, as it may prove to be only an immature or stunted form of that shell.

3. Productus scabriculus, Martin, sp. Plate XX, figs. 16-18, and Plate XXI, fig. 12 .

1809. Anomites scabriculus, Martin. Petrif. Derb., p. 8, pl. xxuvi, fig. 5 .

1841. Leptexa scabricula, Phillips. Pal. Foss., p. 58, pl. xxiv, figs. $97 a, b$. 
1861. Productus scabriculus, Davidson.

1865.
Brit. Foss. Brach., vol. ii, pt. 5, p. 169, pl. xliii, figs. 5-8.

Ibid., vol. iii, p. 103; pl. $x x$, figs. 3 (?), 4-6.

Description. - Ventral valve convex, gibbose, transverse or occasionally slightly elongate. Umbo flattened, moderately elevated, recurved over the hinge-line. Sinus low, broad, undefined. Surface marked on the umbo and wings with coarse concentric ridges, which vanish in front; and also covered by about fifty coarse, close, rounded, irregularly alternating and occasionally discontinuous ribs, occasionally carrying spines (which in some specimens appear to be set forward and in others backwards). Wings with a few large spines in their corners.

Dorsal valve strongly geniculated, marked on the flat portion with coarse, rounded, divaricating ribs, which are crossed and nodulated by closer concentric ridges; these ribs alone being continued over the elbow, in frout of which they are very irregular.

Size.-About $28 \mathrm{~mm}$. long by $34 \mathrm{~mm}$. wide.

Localities.-In the Woodwardian Museum is a ventral valve from Croyde and two dorsal valves. In the Porter Collection is a ventral valve from Smoking House Lane, and two from Pilton, and eight dorsal valves from Pilton, Roborough, and Poleshill.

Remarls. - I have been unable to recognise the Devonshire examples which Phillips and Davidson figured. Their figures of the dorsal valves with their corded ornament and internal markings are clear. Phillips's figure of the ventral valve is certainly very vague in itself, but in conjunction with his description it may be taken to represent a small specimen of this species. Davidson's figure is covered with spines, and it appears very difficult indeed to distinguish it from some of the figures which he gives of Strophalosia productoides, while in a slab in the Davidson Collection labelled by him "St. productoides and P. scabriculus" I have been able to discover only specimens of the former species.

At the same time some ventral valves have been found, which, though generally distorted, appear to present all the characters of this species. Having compared them with numerous Carboniferous specimens, and especially with those in the Bristol Museum, to which Phillips himself likened his Pilton specimens, I see no reason for hesitating to refer them to this Carboniferous form. These specimens correspond, moreover, with a number of dorsal valves from the Pilton beds, of some of which there can be no doubt that they belong to $P$. scabriculus, though it is difficult to be certain whether others can be distinguished from Str. productoides. 
4. Productus interruptus, Sowerby, sp. ? Plate XXII, figs. 1-3.

? 1840. Leptena interrupta, Sowerby. Geol. Trans., ser. 2, vol. v, pt. 3, pl. lvi, fig. 7 .

? 1841. - $\quad$ n. sp.? Phillips. Pal. Foss., p. 229, pl. lviii, fig. 98.

? 1844. Producta interiupta, $\mathbb{I}^{\prime}$ Coy. Synops. Carb. Foss. Irel., p. 110.

? 1865. Provuctus, sp., Davidson. Brit. Foss. Brach., vol. iii, p. 103, pl. xx, fig. 8.

Description.-Ventral valve small, very gibbose, approximately hemispherical. Umbo small, flattened, not prominent, incurving to the hinge-line. Ears apparently small. Ribs numerous, low, rounded, more or less distinct, occasionally divaricating, much interrupted in the umbonal region by a number of deep irregular concentric grooves (which are bounded by ridges) and crossed, especially in the marginal parts, by very numerous, regular, minute, impressed threads. Dorsal valve apparently concave, following the contour of the ventral valve, indistinctly ribbed, and transversely ridged or wrinkled throughout.

Size.-Length $13 \mathrm{~mm}$. , width $11 \mathrm{~mm}$.

Localities.-Six slabs (three of which are from Fremington) containing several specimens are in the Porter Collection. Two specimens from Ashford Strand, one from Fremington and one from Newport near Barnstaple, are in Mr. E. F. G. Bryan's Collection.

Remarks.-This small species has the appearance of being very distinct, but our specimens are all more or less imperfect and in poor condition. The shell seems to be papyraceous. The strong irregular grooves, followed by blunt ridges, which are chiefly seen in the central portions of the shell, break up the ribs into short series in a manner which presents great likeness to $P$. fimbriatus, Martin, ${ }^{1}$ so that it is not impossible that it may prove to be an extreme variety of that species. At the same time in our shells these grooves seem much narrower, so as to cause less extensive interruption to the ribs, and at least in the ventral valve they are only seen in the posterior part of the shell, the ribs being continuous for the marginal half of their length. The umbo, moreover, seems much smaller and depressed, and no spines are now visible upon the ribs. It is probable, therefore, that they are distinct.

Leptæna interrupta, Sowerby, is a shell from the Limestone of Plymouth. Its type is in the Museum of the Geological Society. It was said by Davidson to "appear exceedingly like a small example of the Carboniferous $P$. fimbriatus, Sowerby, or $P$. laxispinus (i.e..P. laciniatus?), $\mathrm{M}^{\prime} \mathrm{Coy}$, which may have got accidentally mixed up among Rev. W. Y. Hennah's Plymouth specimens." Its only

1 1861, Davidson, 'Brit. Foss. Brach.', vol. ii, pt. 5, p. 171, pl. xxxiii, figs. 12-15; and pl. xliv, fig. 15. 
difference, however, from our specimens is that the ribs may be rather more numerous, and that the interruptions extend to the marginal parts; and it appears to me most probable that they both belong to the same species, and therefore that Mr. Hennah's specimen is a Devonian fossil.

The figure of Producta laciniata, $\mathrm{M}^{\circ} \mathrm{Coy},{ }^{1}$ from the Middle Carboniferous of Ireland, which is very like the figure given by Sowerby of his species, but has much finer and more spinous ribs, is regarded by Davidson as possibly a variety of $P$. fimbriatus, though separated from it by $\mathrm{M}^{\circ} \mathrm{Coy}$.

5. Productus corrugatus, $M^{\circ}$ Coy. Plate XXI, figs. 4, 5.

1844. Producta corrugata, M×Coy. Synops. Carb. Foss. Ireland, p. 107, pl. xx, fig. 13.

1845. Productus tenuistriatus, Verneuil. Pal. Russia, vol. ii, p. 266, pl. xvi, fig. 6.

1855. Producta corrugata, ir:Coy. Brit. Pal. Foss., p. 459.

1861. Productus cora, Davidson (? not d'Orbigny). Brit. Foss. Brach., vol. ii, pt. 5 , p. 148, pl. xxxvi, fig. 4 ; and pl. xlii, fig. 9.

1896. - - tenuistriatus, Whidborne. Proc. Geol. Assoc., vol. xiv, p. $37 b^{\circ}$

Description.-Ventral valve large, subglobose, rounded or perhaps sometimes slightly depressed along the centre of the back. Ears small and undefined. Beak wide, convex, incurved, overhanging the hinge-line, and having a few strong foldings or rounded wrinklings on its sides and on the ears. Ribs extremely numerous, minute, rounded, irregularly flexuous, sometimes alternating, divided by similar furrows, and very occasionally bearing minute spines; remaining of a uniform size over the whole valve, and sometimes splitting into two or three and again reuniting. Surface crossed by close, regular, microscopic transverse striæ.

Localities.-In the Porter Collection are nine or ten specimens from Fremington and one from Kingdon's Shirwell; in Miss Partridge's Collection is one from Fremington.

Size.-The specimens are all crushed or imperfect; one is $38 \mathrm{~mm}$. long by $25 \mathrm{~mm}$. wide; others were evidently larger.

Remarlis.-Our shells are rounded or perhaps sometimes flattened on the back, but I have not seen anything in them that amounts to a sinus. The ribs, though always minute, seem to vary in size and number in different specimens, as also do their flexuosity and their habit of division and reunion, which are some- 
times excessive. Davidson's figures show still finer and more numerous ribs than do our shells.

Our shells are so exceedingly like M'Coy's $P$. corrugatus from the Yellow Sandstone and Carboniferous Limestone of Ireland as to be certainly identical with it; for, though $\mathrm{M}^{\circ} \mathrm{Coy}$ says it had no spines, his figure seems to show indications of minute rare spines such as are evident in our specimens. Davidson, following de Koninck, who had examined d'Orbigny's types, united M'Coy's species with the South American P. Cora, d'Orbigny. On the other hand, d'Orbigny's original figure of $P$. Cora ${ }^{1}$ looks totally different. Its spines are much coarser and more frequent, and it has a row of large hinge-spines. Waagen, who figures an Indian example which bears out at least the first two of these distinctions, sides with M`Coy in denying its identity with the English, Irish, and Belgian shell. He divides his section Lineata into two groups: (1) those with a sinus, as $P$. Neffidievi, Verneuil ${ }^{2}$ (which Davidson united to $P$. Cora), and P. lineatus, Waagen; ${ }^{3}$ and (2) those without a sinus, as $P$. Cora, d'Orbigny, and ? $P$. semireticulatus, Martin. Again, Tschernyschew distinguishes the Permio-Carboniferous $P$. tenuistriatus, Verneuil, from $P$. corrugatus, $\mathrm{M}^{\circ} \mathrm{Coy}$ (which $\mathrm{M}^{\circ} \mathrm{Coy}$ had united with it), by the irregularity of the fission and reunion of the ribs, and both these forms from $P$. Cora, d'Orbigny, by the absence of spines on the middle parts of the shell, and by the fineness of the ribs. But our Devonshire specimens are accurately identical with $P$. tenuistriatus in every respect, and in some of them the irregularity and flexuosity of the ribs and the paucity of the spines are fully as great as in the Russian shell which Tschernyschew figures, while in others the ribs seem as straight and the spines as imperceptible as described by $\mathrm{M}^{\mathrm{*}} \mathrm{Coy}$.

It seems, therefore, best to place our shells with $P$. corrugatus and $P$. tenuistriatus, which they prove to be mutually identical, and to leave the disputed question of the identity of $P$. Cora, d'Orbigny, in abeyance.

6. Productus, cf. P. subaculeatus, Murchison. Plate XXI, fígs. 1-3.

Localities. - Two fragmentary specimens from Fremington and one from Pilton are in the Porter Collection. One from Saunton is in the Barnstaple Athenæum.

Size.-Width about $30 \mathrm{~mm}$. Length of a spine more than $44 \mathrm{~mm}$.

1 1842, d'Orbigny, 'Paléont. Voyage Amér. Mérid.' p. 55, pl. v, figs. 8-10.

2 1845, Murchison, Verneuil, and Keyserling, 'Russia,' vol. ii, p. 259, pl. xviii, fig. 2.

3 1884, Waagen, 'Salt Range Brach.,' p. 673, pl, lxvi, figs. 1, 2 ; and pl. lxvii, fig. 3. 
Remarks. - The above-named specimens, which are too imperfect to admit of specific determination, belong to some species of Productus which was covered by numerous, but not crowded, coarse and very long spines, arranged more or less regularly in transverse rows, and apparently most developed in the marginal parts; its umbo appears to be rather small and not very prominent; its ears are small, and bear a few very strong spines; its shape is gibbose and rather transverse; its ventral valve has a small sinus down the back; its dorsal valve is geniculated, and crossed in the flat portion by rather numerous corrugations.

To whatever species these shells belong, they appear to be distinct from the species described above. 'Their surface may perhaps have been something like $P$. spinulosus, Sowerby, ${ }^{1}$ but they are distinguished from that shell by their sinus, their larger size, and the much greater length of their spines. Not one of the specimens is sufficiently good to enable us to ascertain its true shape or the details of its surface-ornament. It is probably related to or even a variety of Productus (or Productella) subaculeatus, Murchison, ${ }^{2}$ but its spines seem more numerous than is usual in that species.

2. Genus-S'rophatōis, King, 1844.

1. Strophalosia productoides, Murchison, sp. Plate XXI, figs. 6-11.

1840. Orthis Productoides, Murchison. Bull. Soc. Géol. Fr., rol. xi, p. 254, pl. ii, figs. $7 a-c$.

1840. Leptena caperata, Sowerby. Geol. Trans, ser. 2, vol. v, p. 3, pl. liii, fig. 4.

1865. Strophalosta productoides, Davidson (pars). Brit. Foss. Brach., vol. iii, p. 97 , pl. xix, figs. 13,14 (only ?).

1871. - - Kayser. Zeitsch. Deutsch. Geol. Gesell., vol. xxiii, p. 638.

Localities.-Baggy Point, Laticosta Cave, Croyde, Saunton, Braunton, Poleshill, Ashford Strand, Frankmarsh, Top Orchard, Roborough, Ashhill Quarry, Pouch Bridge, South Petherwyn. It is abundant and often gregarious, but rather local, being probably confined to particular zones in the Pilton series.

Size.-A specimen measures about $50 \mathrm{~mm}$. long by $55 \mathrm{~mm}$. wide.

1 1861, Daridson, 'Brit. Foss. Brach.,' vol. ii, pt. 5, p. 175, pl. xxxiv, figs. 18-21; and 1880, ibid., vol. iv, p. 299, pl. xxxvi, fig. 11.

2 1865, Davidson, 'Brit. Foss. Brach.,' vol. iii, p. 99, pl. $\times x$, figs. 1, 2 ; and 1882, ibid., vol. v, p. 54 , pl. iii, fig. 22 ; and 1893 , Whidborne, 'Dev. Fauna,' vol. ii, p. 154; see also p. 156, pl. xvii, fig. 12. 
Remarks.-There is some difficulty in defining the specific limits of this abundant shell on account of its variability, and the likeness of some of its shapes to species of Productus.

Its typical form has nearly circular margins and fairly numerous small spinous markings; it is well represented by Murchison's original figure, and by those of Sowerby's Leptrna caperata. Specimens which are rather more transverse than this, and have rather more numerous spinous markings, occur commonly at Pilton (Pl. XXI, fig. 10). In another variety the thorn-like spinous markings are replaced by strong and more or less continuous ribs, and the transverse wrinkles are confined to the posterior half (Pl. XXI, fig. 8); these shells seem in their usual imperfect condition sometimes so similar to $P$. scabriculus that it is not easy to draw the line between them, but they appear distinguishable by their smaller umbones, their broad hinge-lines, and their long hinge-spines. Again, on the other side of the typical form we find one of the commonest variations presented by large elongate flattish shells, in which the umbones are very small, and the spinous markings are minute, short, multitudinous and quincuncially arranged (Pl. XXI, figs. 7,9); in these the transverse wrinkles are very numerous and prominent, and sometimes produce with the spinous markings a zigzag appearance. At first sight this variety has a distinct appearance, but it is most probably only an aged or extreme form of the present shell. Lastly, in a few small shells we find the spinous markings very few, acicular, and confined to the more central parts of the shell, and the transverse ridges prominent and straight ( $\mathrm{Pl}$. XXI, fig. 11); these may be regarded as immature shells. While, however, the above variations may be noted, it must be added that they are not constant, as they are united by intermediate forms, and few shells are exactly alike. There seems, therefore, every reason to believe that they all belong to a single species.

The strong erect spines of the hinge of both valves sometimes reach a length of more than $10 \mathrm{~mm}$. (Pl. XXI, fig. 9). Specimens occasionally occur in which the body-spines are seen to be elongate, crowded, and hair-like over the whole surface. A decayed specimen from Baggy retains them wherever the shell is not obliterated, both on the shoulders and the front portion of the valve (Pl. XXI, fig. 6). While the extreme elongation in shape of some specimens is largely due to contortion, it is probably not to be wholly accounted for by this cause.

Two other variations not occurring in the Barnstaple area must be noticed. At South Petherwyn the shells called by Phillips Leptrna membranacea, ${ }^{1}$ but united by Davidson to this species, are common. These are small and flat; their spinous markings are very few and blunt, while their wrinkles are numerous, prominent, and zigzagged. All the specimens I have noticed are dorsal valves, but a ventral valve is figured by Davidson. Again, in the same beds occur equally 1 1841, Phillips, 'Pal. Foss.,' p. 60, pl. xxv, fig. 101. 
small, rounded, ventral valves, with somewhat larger, scattered, blunt tubercles or spinous markings. These seem to have been referred by Phillips ${ }^{1}$ to his P. laxispina, ${ }^{2}$ but are included in this species by Davidson: St. productoides, Wenjukoff, ${ }^{3}$ and St. calvus, Wenjukoff, ${ }^{4}$ appear closely to correspond with them. It is remarkable that amid the numerous specimens from the Pilton Beds nothing like either of these two forms should have come under my notice, and I reserve for the present my opinion as to their specific identity.

\section{Genus-Chonetes, Fischer de Waldheim, 1837.}

1. Chonetes Hardrensis, Phillips, sp.? Plate XXII, fig. 4.

? 1841. Orthis Hardrensis, - Phillips. Pal. Foss., p. 138, pl. lviii, figs. $104 a-d$; and pl. lx, fig. 104*.

? 1855. Leptema (Chonetes) Harvenesis, M'Coy. Brit. Pal. Foss., p. 454.

? 1861. Chonetes Hardressis, Davidson. Brit. Foss. Brach., vol. ii, p. 186, pl. xlvii, figs. 12-18, 25 ?.

\begin{tabular}{|c|c|c|c|}
\hline 1865. & - & - & Ibid., vol. iii, p. 94, pl. xix, figs. 6-9. \\
\hline ? 1880. & - & LaQUessiana, Davidson. & $\begin{array}{l}\text { Ibid., vol. iv, p. } 312 \text {, pl. xxxiv, } \\
\text { fig. } 18 .\end{array}$ \\
\hline 1882. & - & Hardrensis, Davidson. & Ibid., vol. v, p. 54, pl. iii, fig. 24. \\
\hline ? 1884. & - & A, Davidson. & $\begin{array}{l}\text { Ibid., vol. v, p. } 280 \text {, pl. } 8 x \text {, figs. } \\
20-21 \text { a. }\end{array}$ \\
\hline
\end{tabular}

Description.-Ventral valve small, moderately transverse, suboval. Hinge-line straight, as long as the width of the shell, bearing several obliquely-set spines. Umbo small, incurved, not extending above the hinge. Contour very gently convex. Front margin long, slightly convex. Side margins obliquely couvex. Lateral angles rather less than right angles. Surface covered with very numerous, straight, divaricating rays, which are more or less nodulous. Dorsal valve concave ; interior radially pitted.

Size.-Length $6 \mathrm{~mm}$., width $9 \mathrm{~mm}$.

Localities.-Top Orchard, Ashford Strand, Mainstone, Bradiford, Kingdon's Shirwell, Croyde, Laticosta Cave, Baggy, Upcott Arch Quarry, Wrafton Lane, Rock Hill Quarry, Ashhill Quarry.

1 1841, Phillips, 'Pal. Foss.,' p. 59, pl. xxv, fig. 99.

2 1861, Davidson, 'Brit. Foss. Brach.' vol. ii, pt. 5, p. 166, pl. xxxiii, fig. 18 (under P. aculeatus).

3 1886, Wenjukoff, 'Faun. Der. Syst. Russl.,' p. 45, pl. ii, figs. 5, 6.

4 Ibid., p. 47, figs. 8-10. 
Remar\%s. - This is undoubtedly the shell to which Davidson ultimately restricted the name Ch. Hardrensis; but its title to that name seems rather faulty.

Ch. Hardrensis, though described in Phillips's Devonian work, seems primarily to be a Carboniferous species, his two first and best figures being from Westleigh (Culm) and Yorkshire, though he also quotes it from Berry Pomeroy and Meadfoot. In $1852 \mathrm{M}^{\circ} \mathrm{Coy}$ limited the name to the Carboniferous form, referring the Devonian shells to Ch. sarcinulata (Schlotheim). Davidson, in 1865, united under it both the Carboniferous and Devonian shells, quoting it as especially abundant from near Barnstaple, figuring "one of Phillips's original specimens" from North Devon, and uniting with it Leptæna sordida, Sowerby. In 1880, however, in deference to the opinion of de Koninck, he reluctantly separated the Carboniferous shell under the name Ch. Luaquessiana, de Koninck, remarking at the same time that the Rev. W. Downes had found two good examples of Ch. Laquessiana at Westleigh, which is Phillips's first locality for his Ch. Hardrensis. In face of the latter fact, can Phillips's be superseded by a later name for the Carboniferous shell, if it is distinct from the Devonian form? But further, though possibly Davidson may have included more than one species among the numerous Carboniferous varieties which he records, some of them, including the typical Carboniferous shape, seem impossible to be distinguished from our Pilton shells (at all events in their present state of preservation). Lastly, it is also to be noted that the shell which in 1882 he figures from Hope's Nose seems also to coincide with them. On the whole it seems best to retain Phillips's name for these common Pilton shells, only remembering that, if the Carboniferous shell be ultimately proved distinct, it has a strong claim to retain the name Hardrensis for itself.

As seen in the Pilton Beds our species is very variable. Its diversity in shape is doubtless exaggerated by distortion, but its fine divaricating rays vary considerably in size and number, while they have a granular appearance, and sometimes show the characteristic arrangement of minute regular and close concentric striæ. The hinge-spines are only very imperfectly seen in any of our specimens, but the slight indications of them occasionally visible seem to have the same obliquity as in Phillips's type. 


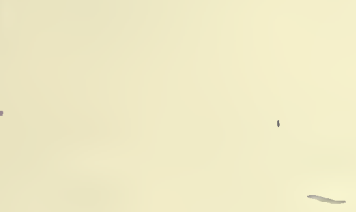




\section{PLATE XVII.}

Fra.

\section{Leptonesma, sp. (Page 121.)}

1. Specimen defective, but showing portions of the wings. Saunton Point (in a pebble). Hamling Collection.

\section{Aviculopectex nexilis, Sourerby, sp. (Page 129.)}

2. Portion of the surface of a specimen, $\times 15$. Laticosta Cave, Baggy. My Collection.

3. Slab, with moulds of the opposite valves, apparently of a single shell, $\times 3$. Laticosta Care, Baggy. My Collection.

\section{Pterinopecten scabriradians, n. sp. (Page 135.)}

4. Specimen of a right valve, showing ornament and anterior wing clearly, but defective below, $\times 3$. Wrafton Lane. My Collection.

\section{Permopecten insperatus, $\mathrm{n} . \mathrm{sp}$. (Page 143.)}

5. Specimen, showing the projecting wings, $\times \frac{3}{2}$. Top Orchard. Barnstaple Athenæum.

\section{Prothris, sp. (Page 144.)}

6. Left valie, showing the anterior notch (which is fractured) and the radiating and transverse markings, $\times \frac{3}{2}$. Sloly Quarry. My Collection.

\section{Renssemizaia? formosa, n. sp. (Page 145.)}

7. Specimen, showing umbonal arrangements and texture, but so much distorted as to simulate Leptrna laticosta in shape, $\times \frac{3}{2}$. $7 a$. Portion of surface, $\times 40$. Poleshill. Porter Collection.

8. Large specimen, showing the cast of the dental plates, \&c., and the rounded shape of the ribs, $\times \frac{3}{2}$. $8 a$. Umbonal portion, $\times 3$. Ashford Strand. My Collection.

9. Portion of the surface of a fragmental specimen, $\times 40$, showing the pores and the shape of the ribs. Ashford Strand. Mr Collection.

\section{ATHYRIS? sp. (Page 146.)}

10,10 a. Dorsal and lateral views of a minute undetermined species, $\times 6$. Pilton. Porter Collection.

\section{Athris (Seminula) oblonga, Sowerby, sp. (Page 147.)}

11. Cast of the closed valves, showing the slight marginal fold and indications of the marks left by the vascular sinuses, $\times 2$. $11 a$. Portion of the mould of the same individual, showing its smooth surface, $\times 3$. Ashford Strand. My Collection.

12. Cast of the dorsal valve of rather doubtful specimen, which has a stronger and wider fold than usual, $\times \frac{3}{2}$. $12 a$, umbonal part, $\times 3$. Barnstaple. Woodwardian Museum.

\section{Athyris (Cleiothrris) Royssit, Léveillé, sp. (Page 148.)}

13. Specimen figured by Davidson as Terebratula elongata, Schlotheim (?), but exactly corresponding with casts of this species, $\times \frac{3}{2}$. Braunton. Museum of Practical Geology.

14. Cast of the ventral valve of a rather doubtful specimen, $\times 2$. Roborough. Porter Collection.

15. Mould of the ventral valve of a small specimen, showing the surface and the beginnings of the crura, $\times 2$. $15 a$, Umbonal part, $\times 5$. Pilton. Porter Collection. 
PLATEXVII.
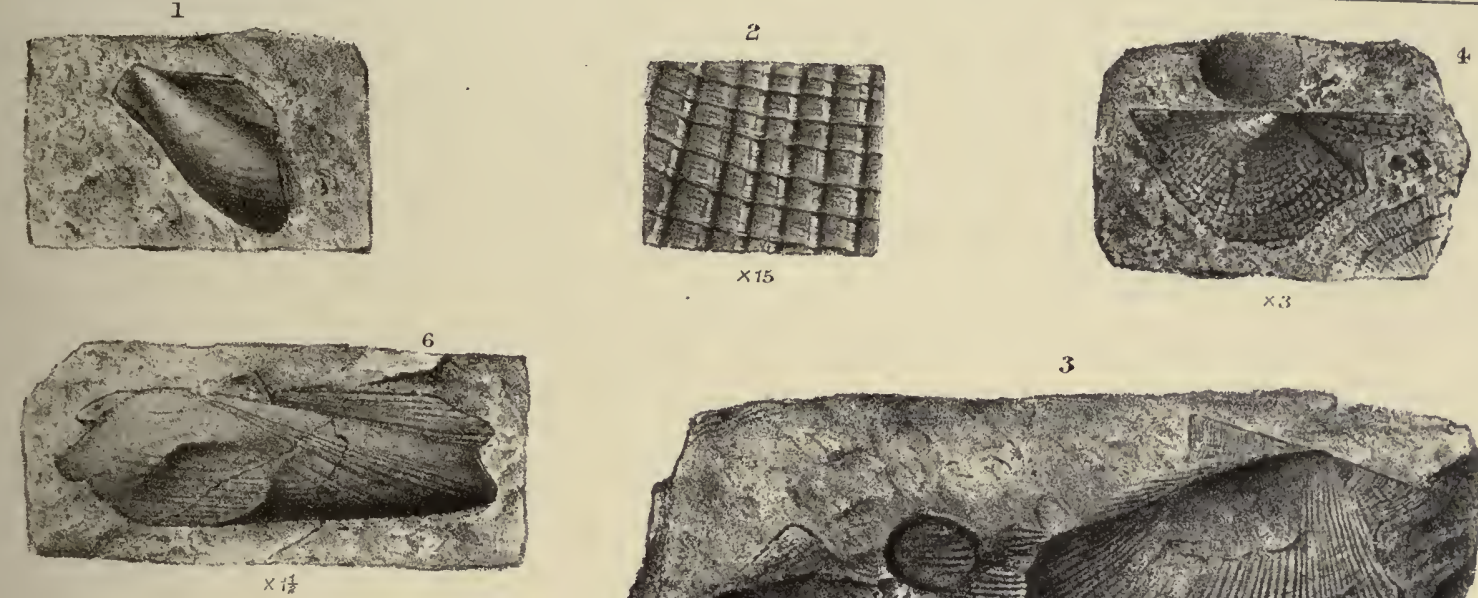

3
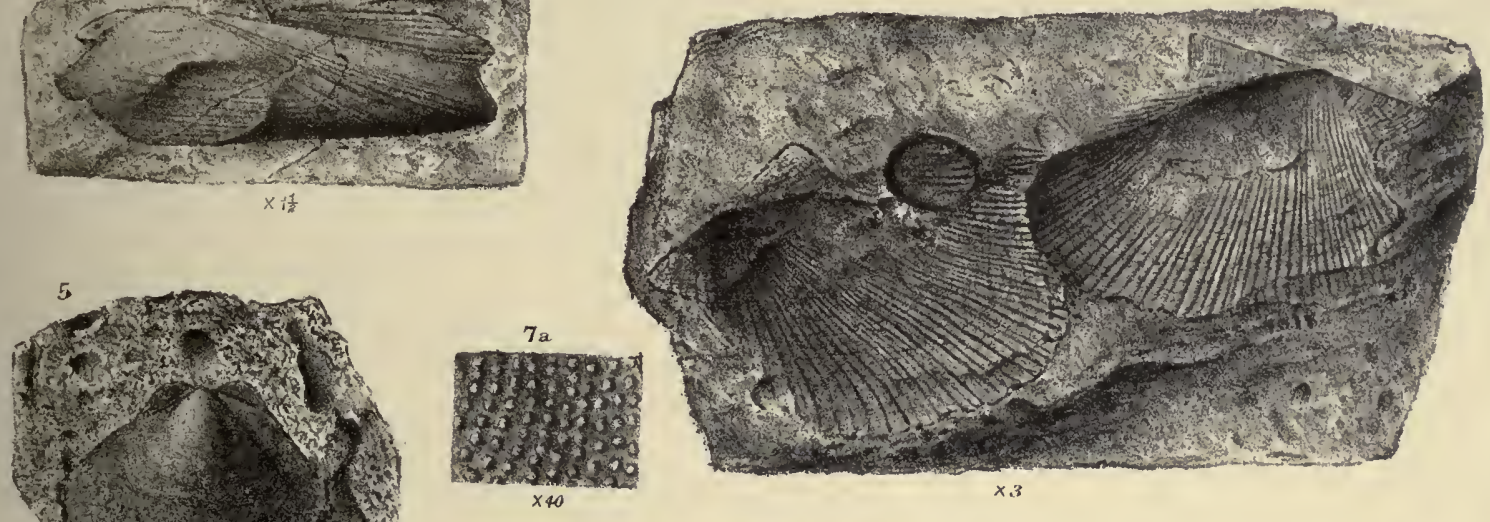

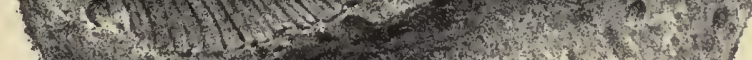

$x .3$

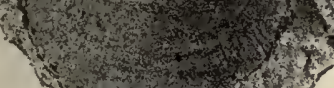

$\times 1 \frac{1}{2}$

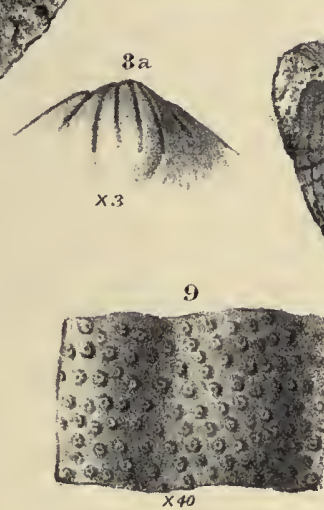

*)

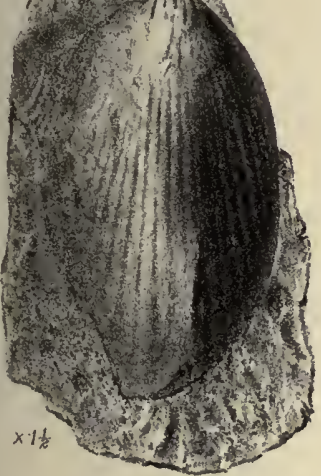

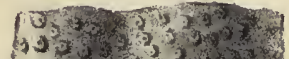

7
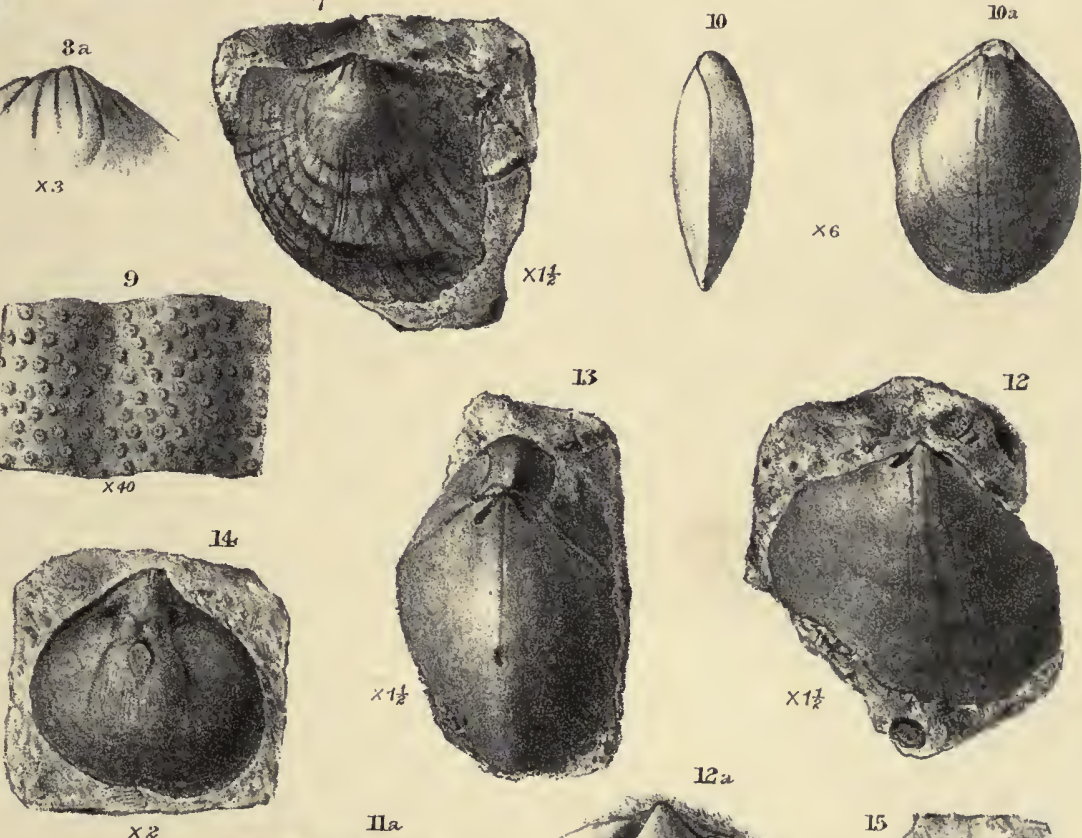

$12 a$
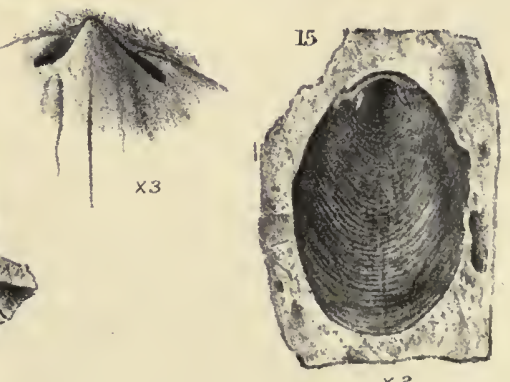




\section{PLATE XVIII.}

Fig.

\section{Athyris (Cleiothyris) Royssii, Léveillé, sp. (Page 148.)}

1. Dorsal view of the cast of a young specimen, showing the central septum and the muscle-scars, $\times 3$. Croyde. Museum of Practical Geology.

2. Dorsal view of a similar specimen, showing the spire, $\times 3.2 a$, posterior view, showing the opening of the visceral canal, $\times 3$. Croyde. Museum of Practical Geology.

3. Mould of another young specimen, showing the ornament, $\times 3$. (This figure is drawn out of the perpendicular.) Poleshill. Porter Collection.

4. Mould of a large distorted specimen, showing the fold and the ornament, which becomes closer and more spiniferous near the margins, $\times 2$. Pouch Bridge. Barnstaple Athenæum.

5. Distorted mould of another large specimen, with unusually numerous striæ, $\times 2$. Pilton. Porter Collection.

\section{Species Inde'ter.}

6. Cast of a ventral valve, showing muscular marks and signs of probable ribs, $\times 2$. Poleshill. Porter Collection.

\section{Stirifera microgemara, Phillips. (Page 151.)}

7. Cast taken from the mould of a valve, showing ornament, but distorted in the region of the sinus, $\times 2.7$ a. Portion, $\times 5$. Pilton. Porter Collection.

8. A distorted dorsal valve, showing the fold, $\times \frac{3}{2}$. Top Orchard. Barnstaple Athenæum.

\section{Spirifera Verneullit, Murchison. (Page 152.)}

9. A crushed individual, showing the hinge, $\times \frac{3}{2}$. Pilton. Porter Collection.

10. Portion of the cast of a specimen of the variety Sp. Barumensis, showing the spires.

11. Portion of the surface of a large specimen, showing the minor longitudinal ornament, $\times 10$. Ashford Strand. Barnstaple Athenæum.

12. Portion of another specimen, in which the transverse ornament is strong and the minor longitudinal ornament invisible, $\times 10$. Ashford Strand. Barnstaple Athenæum.

13. Ventral valve, seen from within, $\times \frac{3}{2}$. $13 a$, portion of surface, $\times 15$, showing the arching lines of pores. Snapper Quarry. My Collection. 

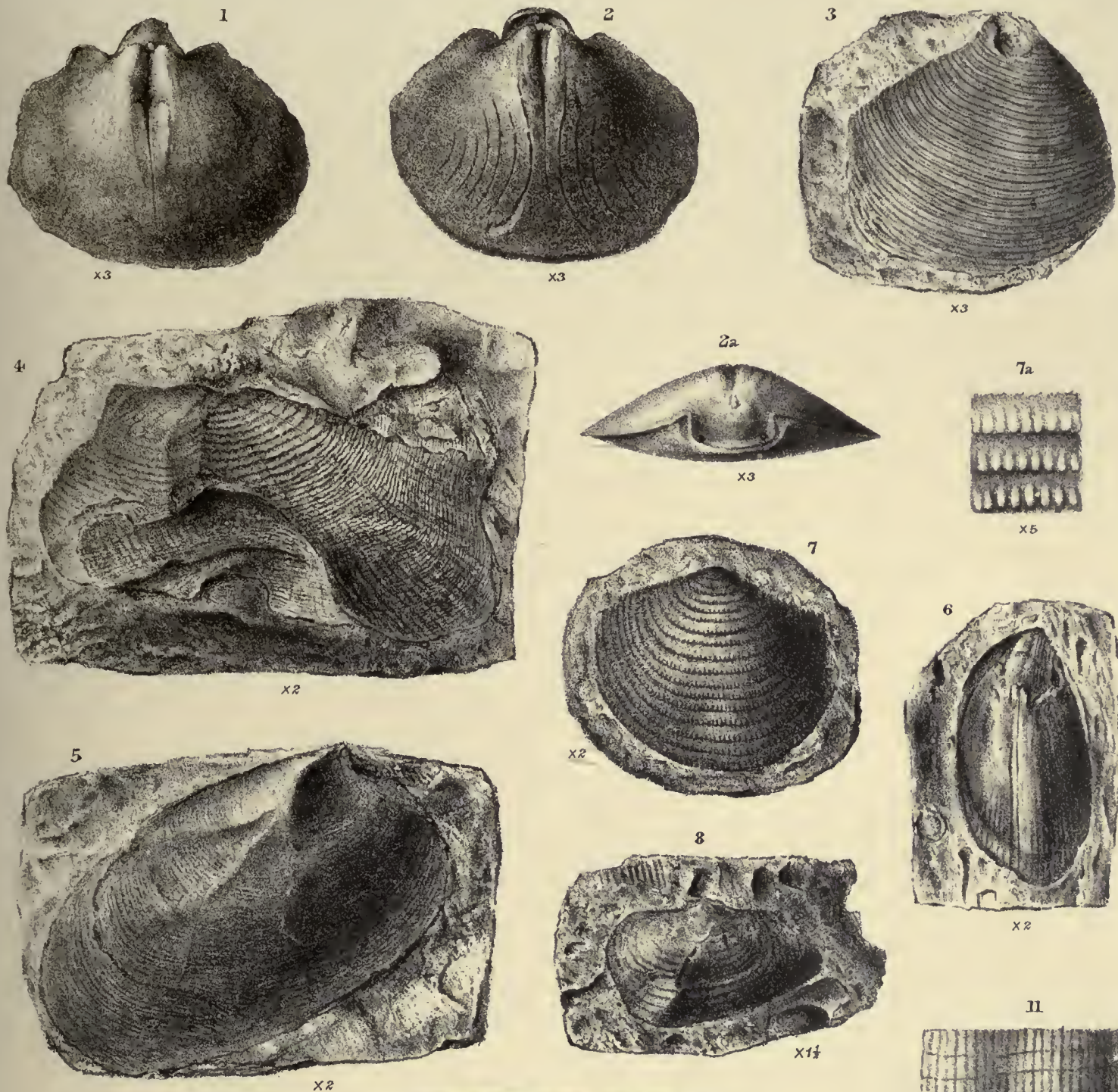

$7 a$
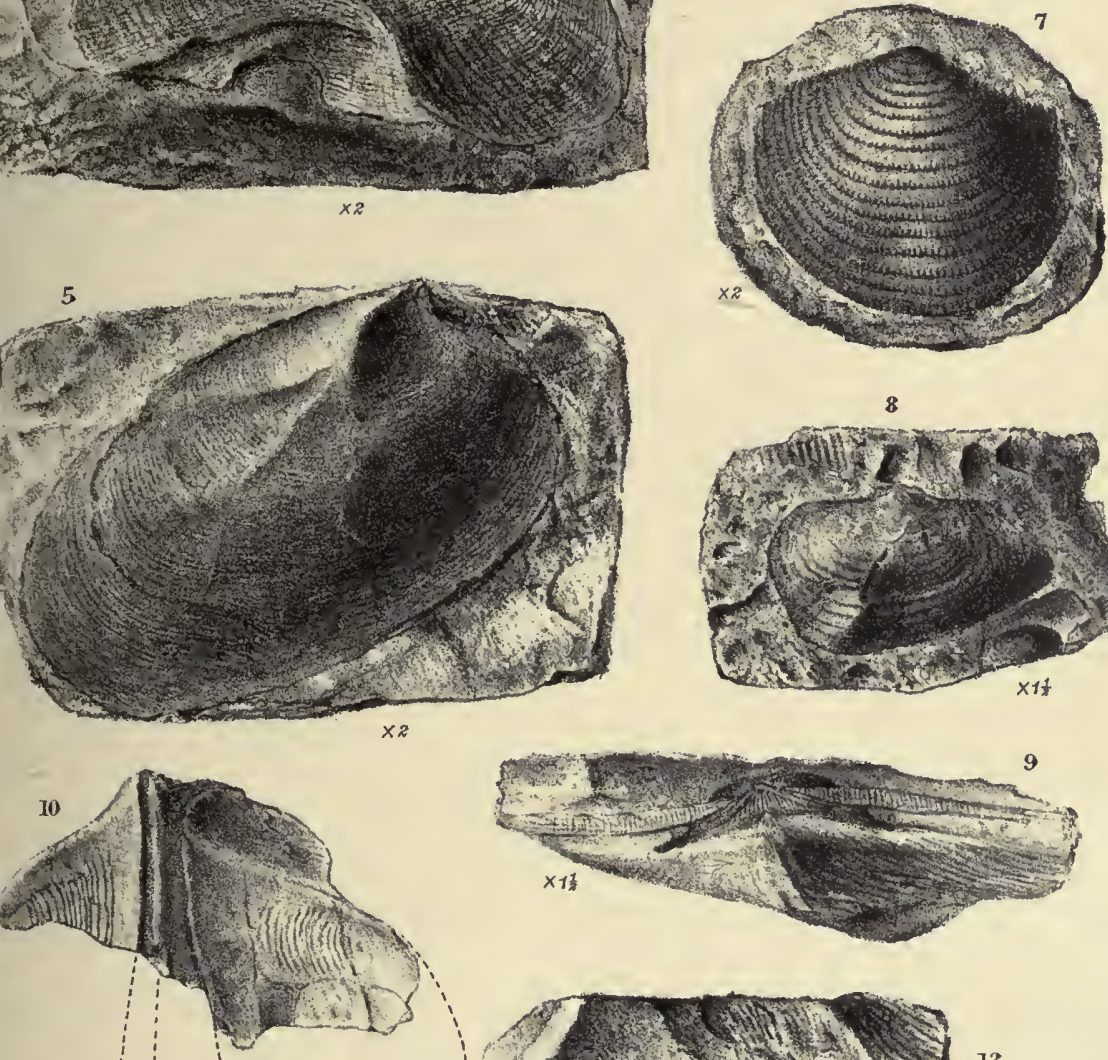

\section{8}
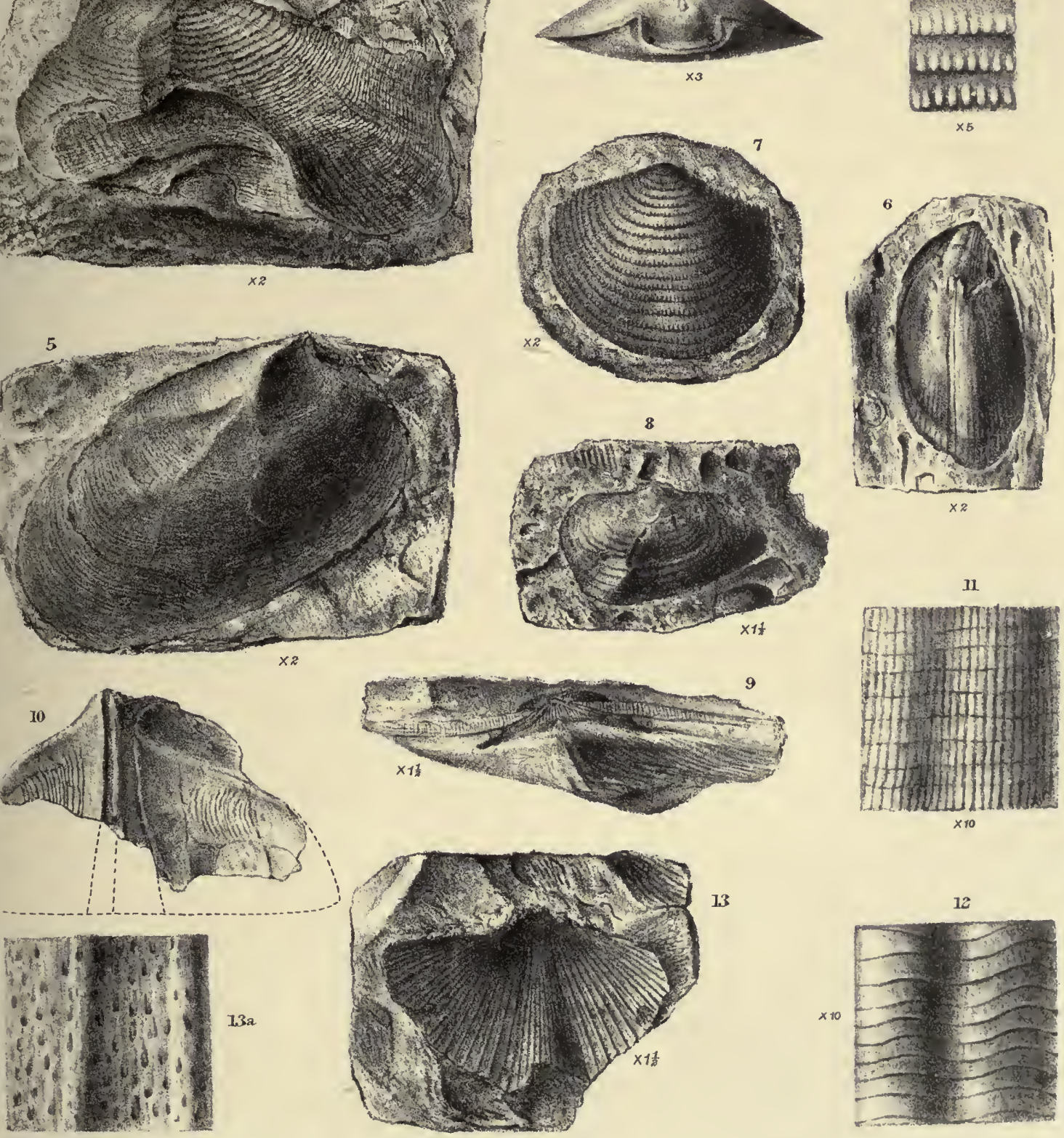

13

12 



\section{PLATE XIX.}

FIG.

\section{Spirifera obliterata, Phillips. (Page 156.)}

1. Phillips's type specimen, being a ventral valve, $\times \frac{3}{2}$. Brushford. Museum of Practical Geology.

2. Specimen of a dorsal valve, $\times \frac{3}{2}$. Top Orchard. Hamling Collection.

3. Another specimen with numerous ribs, $\times \frac{3}{2}$. Ashbill Quarry. My Collection.

4. A small specimen of the umbonal part of a dorsal valve, $\times 3$. 4a, umbo, $\times 6$. Frankmarsh. My Collection.

\section{Spirifera Urir, Fleming. (Page 157.)}

5. An unusually large specimen of the ventral valve, $\times \frac{3}{2}$. Roborough. Porter Collection.

6. A ventral valve, apparently of a variety of this species, with an unusually small beak and a very deep angular sinus, $\times 2$. Barnstaple. Woodwardian Museum.

7. A small specimen of the dorsal valve, $\times 3$. Ashhill Quarry. My Collection.

\section{Spirifera mesomala, Phillips. (Page 158.)}

8. A small defective ventral valve with well-preserved surface, showing the smooth median sinus, $\times 5$. Saunton Hotel. My Collection.

9. A small and very badly preserved ventral valve, either of this species, or, more probably, of $S p$. Verneuilii, $\times \frac{3}{2}$. $9 a$, view of area. 9b, side view. Sloly Quarry. Mr. Upfield Green's Collection.

\section{Spiriferina cristata (Schlotheim), var. octoplicata, Sowerby. (Page 159.)}

10. Specimen of a ventral valve, showing the plaited surface, $\times 3$. Poleshill. Porter Collection.

11. A small ventral valve in the state of a cast, $\times 2$. $11 a$, portion, $\times 15$, showing the puncta of the surface. Poleshill. Porter Collection.

\section{Rhynchonelis Pantridgie, Whidborne. (Page 161.)}

12. Cast of dorsal valve, showing the fold with four ribs, $\times \frac{3}{2}$. $12 a$, umbonal portion, $\times 4$, showing the hinge arrangement. Pilton. Porter Collection.

13. Ventral valve, showing the sinus with three ribs, the ridge bounding the muscular area, and the apical grooving of the ribs, $\times 2$. Pilton. Porter Collection.

14. Another specimen, $\times \frac{3}{2}$. Roborough. Porter Collectiou.

\section{RHYNCHONELIA TOGata, n. sp. (Page 163.)}

15. Ventral valve, showing the two ribs on the sinus, $\times \frac{3}{2}$. "North Devon." Museum of Practical Geology.

16. Another ventral valve, showing the coarse distant ribs and the muscular area. Marwood. Museum of Practical Geology.

17. Umbonal portion of another dorsal valve (which has three ribs on the fold). Pilton. Barnstaple Athenæum.

18. A very defective dorsal valve, with no indication of lateral ribs, $\times \frac{3}{2}$. Barnstaple. Museum of Practical Geology. 
PLATE XIX.

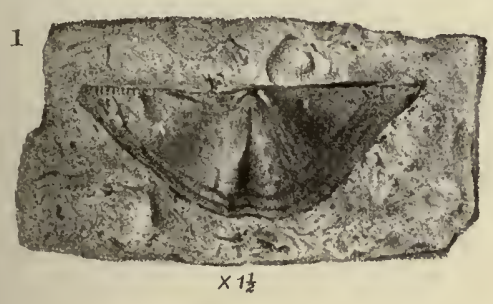

(1)
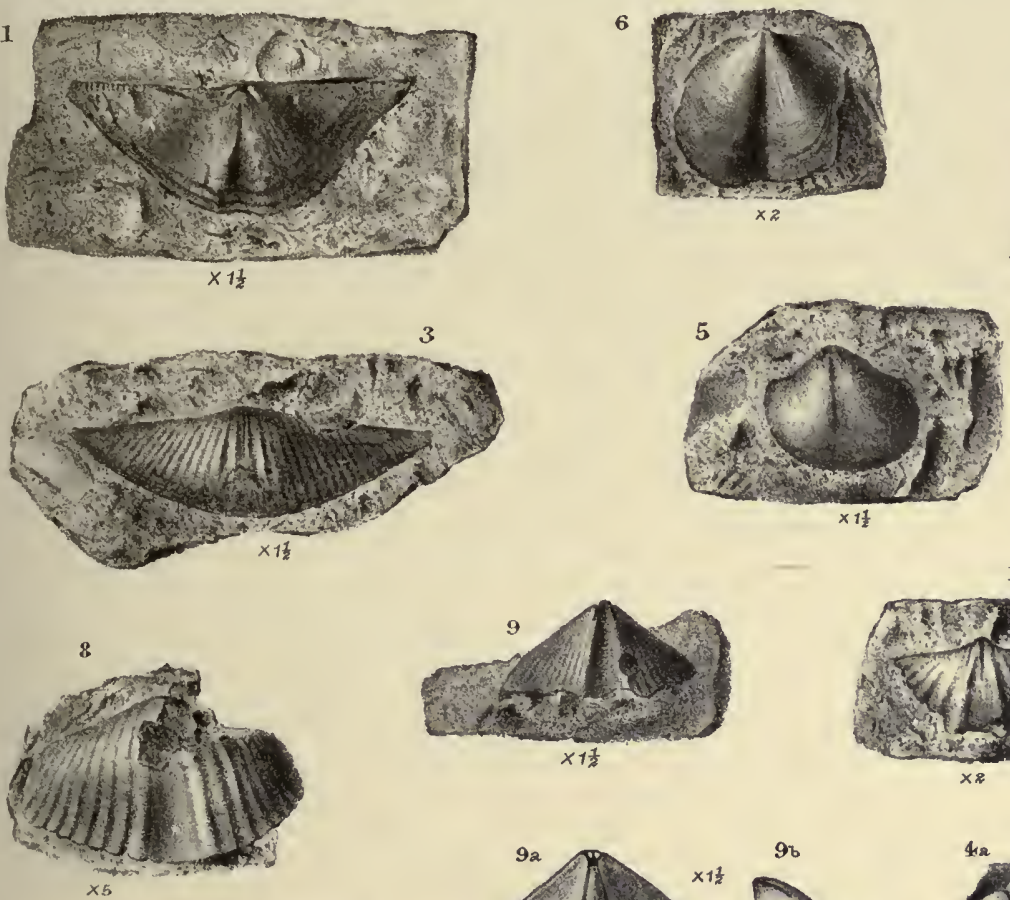

$$
11
$$
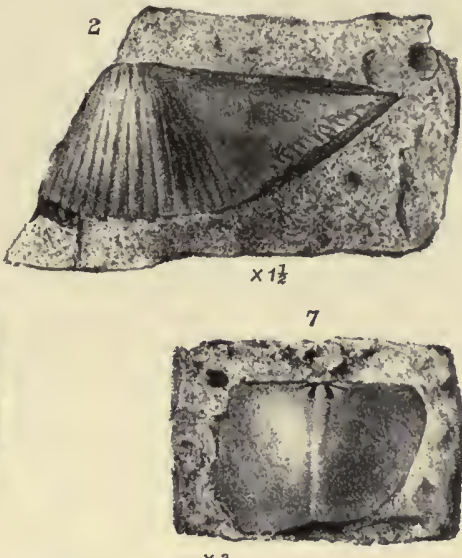

$\times 3$

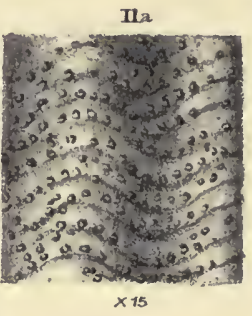

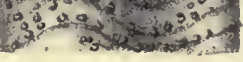
$\times 15$ r.t.
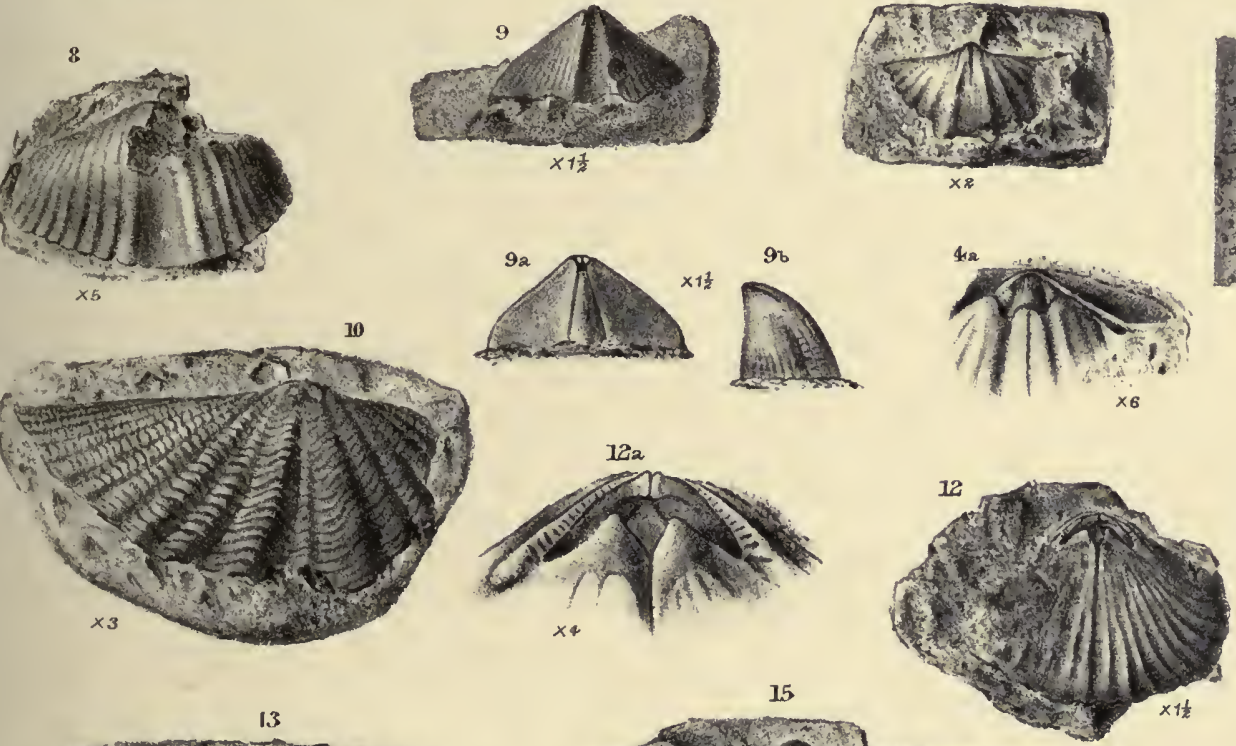
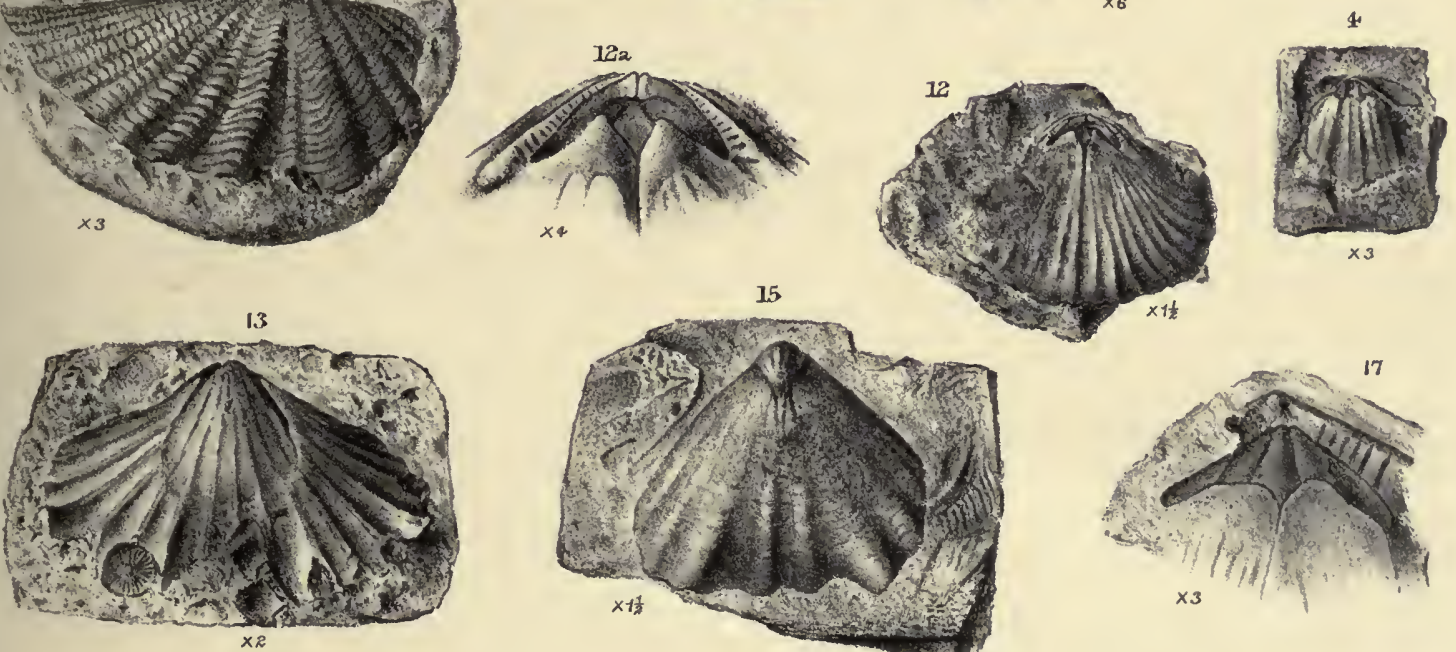

$\times 3$
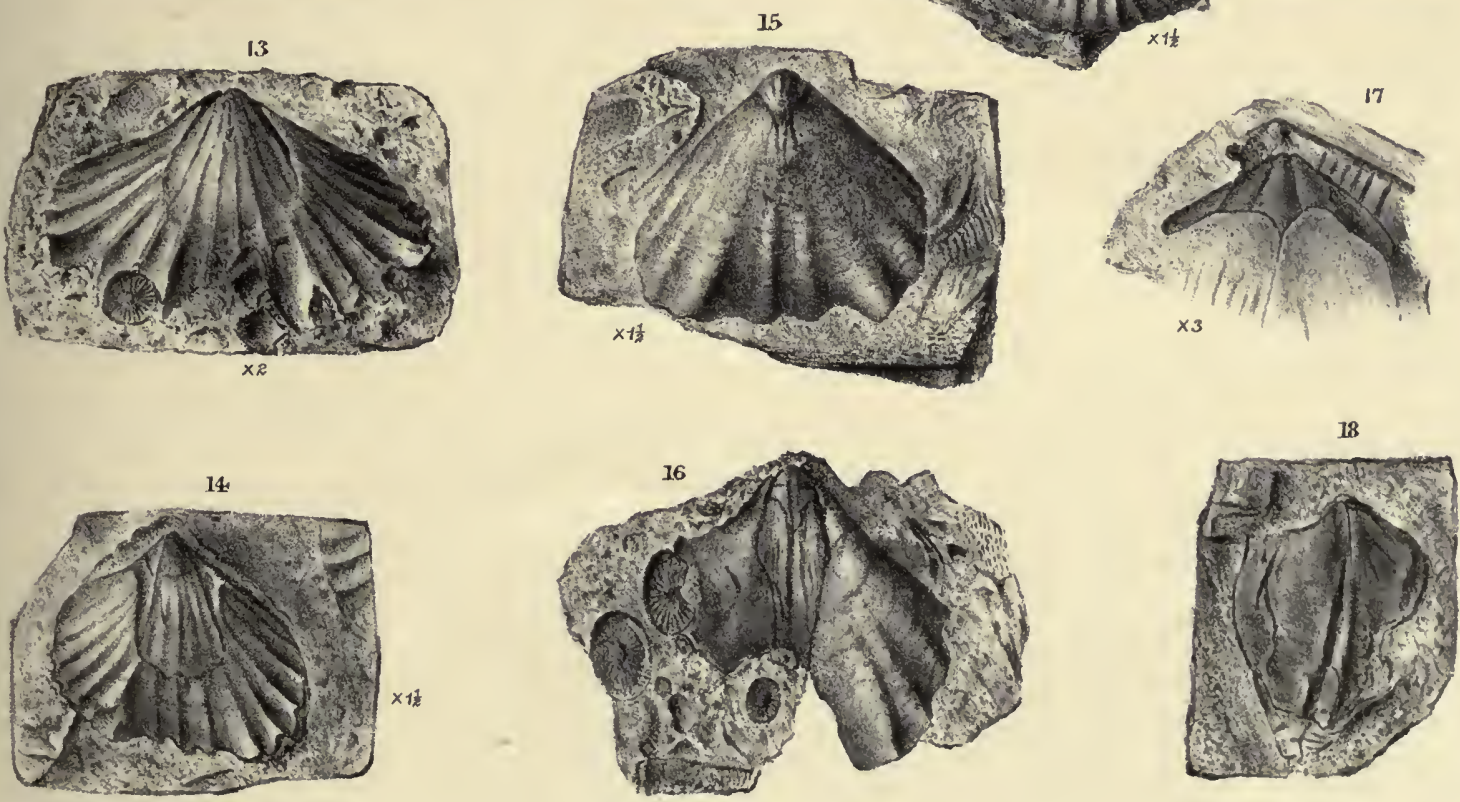

$-$ 


\section{PLA'TE XX.}

F1a.

\section{Athris (Cleiothyris) Rorssit, Léveillé, sp. (Page 148.)}

1. Portion of the mould of a specimen, showing the spines, $\times 8$. Poleshill ? Porter Collection.

2. Portion of the mould of another specimen, showing the transverse ridges and the commencement of the spines, $\times 8$. Pilton. Porter Collection.

Rhinchonelia latroosta, Phillips, sp. (Page 164.)

3. Large obliquely distorted specimen. $3 a$. Another view. Laticosta Care, Baggy. My Collection.

4. Cast of a smaller dorsal valve, showing the median septum. Laticosta Care, Baggy. My Collection.

Strophomena rhomboidalis, Wilckens, sp. (Pige 168.)

5. Interior of a dorsal valve. Pilton. Porter Collection.

\section{Orthis interlineata, Sowerby. (Page 165.)}

6. Cast of a dorsal valve, $\times 2$. Pilton. Porter Collection.

7. Cast of a ventral valve, $\times 2$. Pilton. Porter Collection.

\section{Orthis, sp. (Page 165.)}

8. Specimen, drawn from a wax cast of a mould, $\times 6$. 8 a, Portion of shell, $\times 30$, showing markings, which may, however, be partly due to weathering. Saunton? Porter Collection.

9. Specimen, $\times 6$. Saunton? Miss Partridge's Collection. (The slab on which this lies proves to be the reverse of the slab in the Porter Collection; it contains several small specimens, and the artist appears to have chosen the cast of the same shell as that in the last figure.)

\section{Orthotetes crenistria (Phillips), var. arachioidea, Phillips. (Page 166.)}

10. Portion of a large variety, with very fine and numerous ribs, $\times 2$. "Blagiford Paper Mills," Ilfracombe Road. Porter Collection.

11. Portion of another specimen, with few and coarse ribs, $\times 2$. Saunton Down, south end of Croyde Bay. Hamling Collection.

\section{Productus Prelongus, Sowerby, sp. (Page 168.)}

12. Dorsal valve, showing the median rib and the ears, $\times \frac{3}{2}$. $12 a$, side view, $\times \frac{3}{2}$. Top Orchard, Barnstaple Athenæuın.

13. Small ventral valve, showing the scars of spines in the sinus and on the ears, $\times 2.13 a$, side view, $\times 2$. Pilton. Porter Collection.

\section{Productus prelongus, var. simplicior, n. var. (Page 169.)}

14. Specimen partially hid by matrix, showing the absence of a median sinus, and the presence of short scattered spines, $\times 2$. 14 $a$, portion of shell enlarged. Poleshill. Porter Collection.

15. Another specimen, with smaller umbo, $\times 2$. $15 a$, side view, $\times 2$. Barnstaple. Woodwardian Museum.

\section{Productus scabriculus, Martin, sp. (Page 170.)}

16. A transverse ventral valve, nat. size. Smoking House Lane. Porter Collection.

17. Another distorted specimen, with scars of spines on the ears. Woodwardian Museum.

18. Portion of mould of dorsal valve, $\times 10$. Pilton. Porter Collection. 


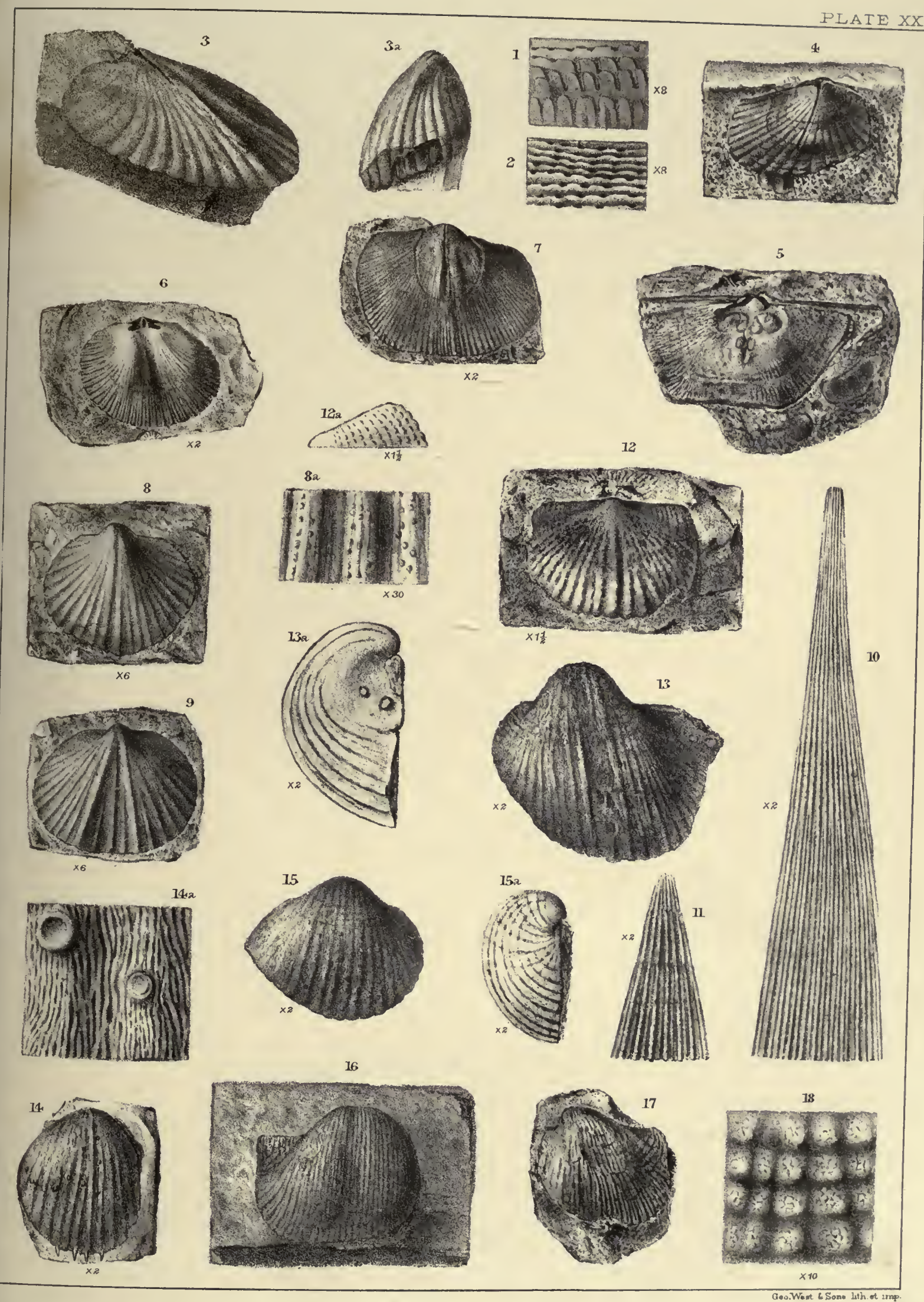





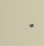

$=$, 


\section{PLA'TE XXI.}

Produotus cf. P. subaculeatus, Murchison. (Page 174.)

FIG.

1. Imperfect dorsal valve, with the casts of long spines of the ventral valve. Pilton. Porter Collection.

2. Fragment of the mould of a ventral valve, showing casts of long spines, $\times \frac{3}{2}$. Fremington. Porter Collection.

3. Worn cast of a valve, showing the scars of spines in transverse rows, $\times \frac{3}{2}$. Fremington. Porter Collection.

\section{Produotes dorrugatus, $M^{6}$ Coy. (Page 173.)}

4. Oblique view of a worn specimen, with less flexuous ribs than usual. Fremington. Porter Collection.

5. Dorsal valve, most probably of this species, seen from within. Fremington. Porter Collection.

Strophalosia productoldes, Murchison, sp. (Page 175.)

6. Posterior part of a decayed specimen, which is covered (wherever the surface is not totally obliterated) by crowded hair-like spines. Laticosta Cave, Baggy. My Collection.

7. Dorsal valve, showing hinge-area and hinge-spines; part of the centre being broken away, another specimen is disclosed, which shows the attachment of the spines, $\times \frac{3}{2}$. $\quad 7$ a. Portion of the latter specimen, $\times 8$. Poleshill. Porter Collection.

8. Ventral valve, with very long ribs and hardly any signs of spines, except on the hinge. Poleshill. Porter Collection.

9. Specimen, showing the length of the hinge-spines, $\times \frac{3}{2}$. Pilton. Porter Collection.

10. Transverse specimen, with short ribs, $\times \frac{3}{2}$. Poleshill. Porter Collection.

11. Young specimen, with very few short ribs in the median parts, $\times 2$. Poleshill. Porter Collection.

\section{Produotus soabrioulus, Martin, sp. (Page 170.)}

12. Large elongate dorsal valve, showing the hinge-area. Pilton. Porter Collection. 


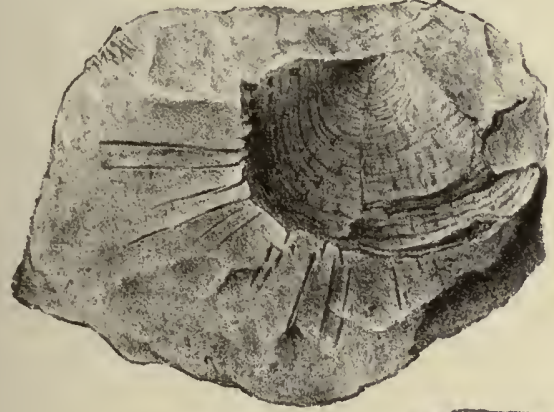

6
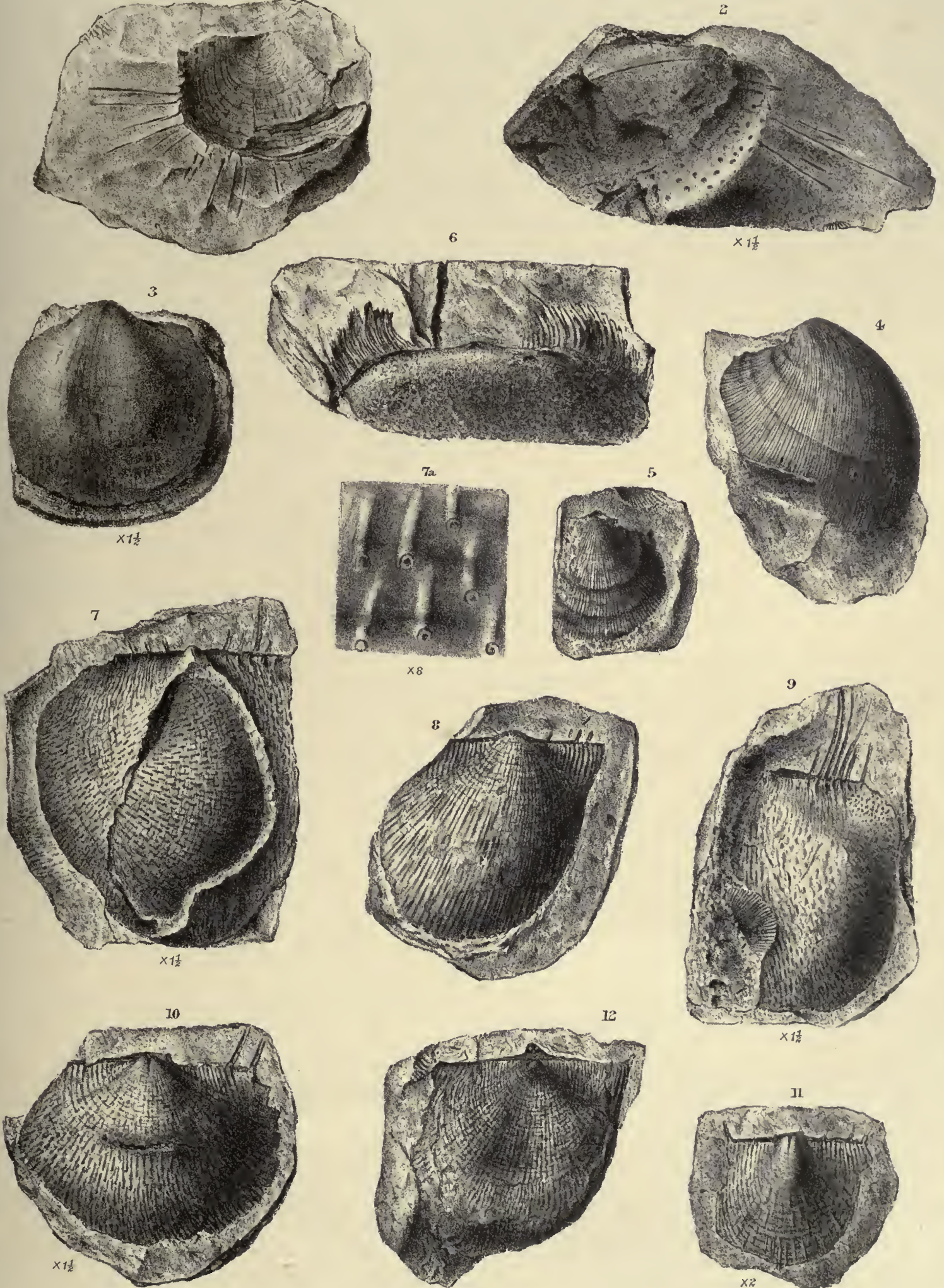

12
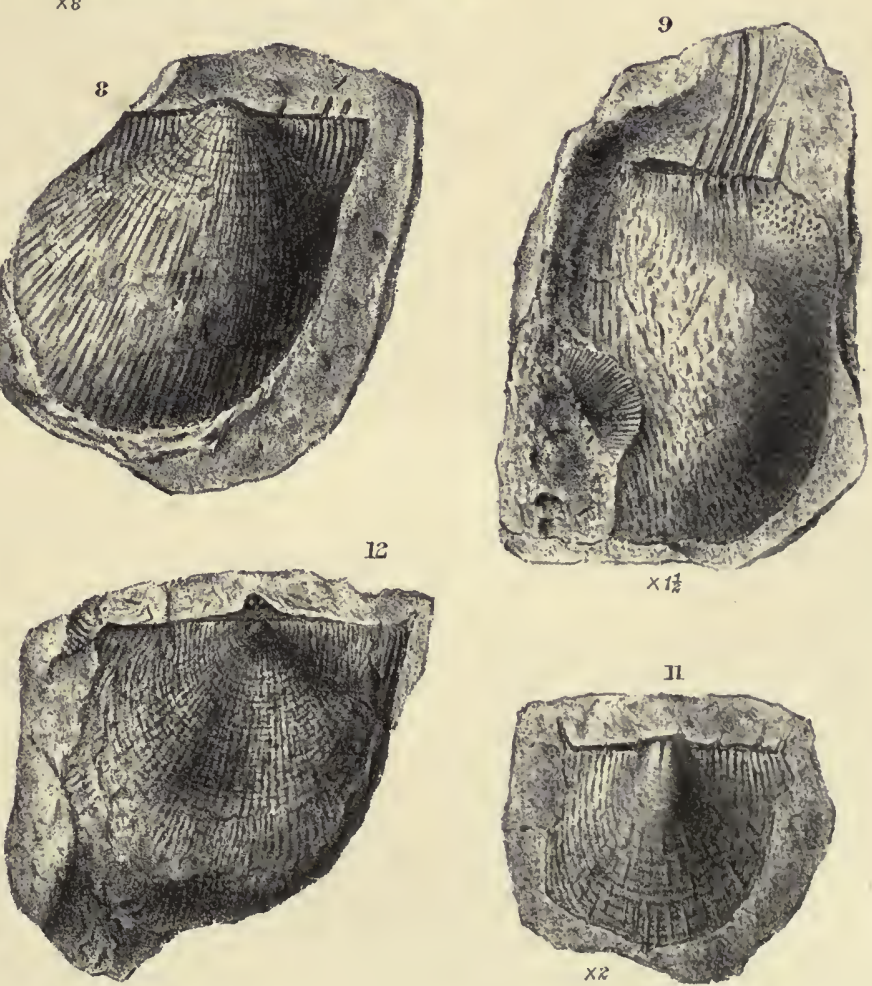

Geo When LSome lith at imp 



$$
\text { , }
$$



Vok 32

THE

\section{PALAONTOGRAPHICAL SOCIEIY.}

INSTITU'UTED MDCCCXLVII.

VOLUME FOR 1898.

L O N D O N :

M DCcCXcviII. 



\section{A MONOGRAPH}

OF THE

\section{DEVONIA N \\ FAUNA}

OF THE

SOUTH OF ENGLAND.

$\mathbf{B Y}$

G. F. WHIDBORNE, M.A., F.G.S.

Vot. III.-PaRT III.

THE FAUNA OF THE MARWOOD AND PILTON BEDS

oF

NORTH DEVON AND SOMERSE'T

(continued).

Pages 179-236; Plates XXII-XXXVIII.

LON D O N :

PRINTED FOR THE PALAONTOGRAPHICAL SOCIETY.

1898. 
PRINTED BY ADLARD AND SON,

BAHTHOLOMIW CLOȘE, E.C., AND 2O, HANOVER SQUARE, W. 
2. Chonetes margaritacea, Whidborne. Plate XXII, figs. $5,5 a, 6$.

1896. Chonetes margaritacea, Whidborne. Proc. Geol. Assoc., vol. xiv, p. 376.

Description.-Ventral valve small, very transverse, semi-oval. Umbo low, rounded, very slightly extending over hinge. Hinge-line straight, equal to the width of the shell in length, bearing three (or four) nearly perpendicular spines. Margins very gently curved in front, gradually increasing in curvature laterally, and meeting the hinge-line at nearly right angles. Contour of surface moderately convex, becoming flatter on the wings. Ribs about thirty, low, rounded, divided by narrower concave furrows, vanishing on the wings, and crossed by minute regular sharp distant concentric threads, which are twice as close as the ribs.

Size.-Length $7 \mathrm{~mm}$., width $15 \mathrm{~mm}$.

Localities.-In the Porter Collection are six specimens from Roborough, Poleshill, and Pilton; in the Barnstaple Athenæum one from Bradiford; in the Museum of Practical Geology one from Braunton; and in my Collection one from Croyde.

Remarlis.-This beautiful shell is distinguishable from Ch. Hardrensis, with which it occurs, by its somewhat larger size, its more transverse and oval shape, and its much larger, fewer, and more simple ribs, as well as by its pronounced concentric ornament.

From Ch. Phillipsii, Davidson, ${ }^{1}$ it differs in its more oval and transverse shape and its considerably finer ornament.

Ch. plebeia, Schnur, ${ }^{2}$ appears to be less transverse, and to have less simple ribs and more oblique hinge-spines.

3. Chonetes Iluinoisensis, Worthen? Plate XXII, figs. 7, 8.

? 1858. Chonetes Logani, Hall (not Norwood and Pratten). Geol. Rep. Iowa, vol. i, pt. 2, p. 598, pl. xii, figs. $1 a-e, 2$.

P1860. - - Ildinolsexsis, Worthen. Trans. St. Louis Acad. Sci, vol. i, p. 571.

? 1868. - _ M Meek and Worthen. Geol. Surv. Illin.. rol. iii, p. 505 , pl. xv, figs. $8 a, b$.

1896. - - Whidborne. Proc. Geol. Assoc., vol. xiv, p. 376.

Description.-Shell rather small, transverse. Hinge-line straight, nearly as long as the width of the shell. Margins moderately convex in front, their

1 1882, Davidson, 'Brit. Fuss. Brach.,' vol. v, p. 54, pl. iii, figs. 23, 23 a.

2 1897, Whidborne, 'Quart. Journ. Geol. Soc.,' vol. liii, p. 454, pl. xxxiii, figs. 1, 2. 
convexity gradually increasing on the sides, the extremities of which meet the hinge-line at an obtuse angle. Ventral valve moderately convex. Dorsal valve flat, becoming concave near the margins. Hinge-line with (at least) two very long, thin, slightly oblique spines on each side in the ventral valve. Surface covered with multitudinous elevated, rounded, divaricating and sometimes rather flexuous, minute radiations (probably about 150 ).

Size.-A distorted specimen is $8 \mathrm{~mm}$. long by $15 \mathrm{~mm}$. wide.

Locality.-In the Porter Collection are two slabs, containing several specimens froin Pilton or Fremingtou.

Remarks. - These fossils appear distinguished by the very great number of the ribs, as well as by the flexuosity of these ribs, which seems to be caused by their frequent divarication at irregular intervals.

They are very similar to Chonetes Dalmaniana, de Koninck, ${ }^{1}$ as given by $\mathrm{M}^{\circ} \mathrm{Coy}^{2}$ and Davidson, ${ }^{3}$ but appear to differ by their longer, less oblique, and (apparently) fewer hinge-spines, and their rounded cardinal angles.

As far as can be judged from Meek and Worthen's figure, they do not appear. distinguishable from Ch. Illinoisensis, though in that figure the length of the spines is not shown, and the sides of the shell seem rather straighter.

2. Order-INAR'TICULATA, Deshayes, 1836.

I. Family-Crannde, d'Orbigny, 1847.

1. Gemus-Cranielia, Whlert, 1888.

1. Crania insecura, n. sp. Plate XXII, fig. 9.

Description.-Cast of dorsal or upper valve irregularly quadrate with rounded angles, rather longer than broad, and widest at or about one-third the diameter from the front. Apex small and sharp, slightly in front of the centre. Contour broadly conical, but having two large indistinct swellings before the apex, one on each side, in front of which the surface sinks steeply to the margin. Anterior margin almost straight; lateral margins oblique and slightly arching; posterior margin straight, and only half the width of the anterior. Margins (in cast) with a broad concave border. Occlusor muscle-marks two, concave, ovoid

1 1843, de Koninck, 'Discr. Anim. Foss. Terrain Carb. Belg.' p. 210, pl. xiii, fig. 3; and pl. xiii bis, fig. 2.

2 1844, M‘Coy, 'Synops. Carb. Foss. Irel.,' p. 119, pl. xx, fig. 7. Mons. WEhlert informs me that he questions the identity of M'Coy's and de Koninck's species.

3 1861, Davidson, 'Brit. Foss Brach.,' vol. ii, pt. 5, p. 183, pl. xlvi, figs. 7-7 b. 
or pear-shaped, adjacent in front and slanting outwards, situate immediately behind the apex, and one-seventh of the shell in length. Divaricator scars rather larger and more oval than the occlusors, concave, elongate, not slanting, apparently bisected longitudinally, situate at the postero-lateral corners, and touching the inner edge of the marginal rim. Surface (of cast) traversed by an irregular transverse ornament, reproduced from the organism to which it was attached.

Size.-Length $13 \mathrm{~mm}$., width $12 \mathrm{~mm}$, depth $7 \mathrm{~mm}$.

Localities.-In the Barnstaple Athenæum is a specimen on a slab with Productus prælongus, Rhynchonella Partridgiæ, \&c. Though its locality is not stated, it is clearly from the equivalent to the Top Orchard beds. A doubtful specimen is in the Porter Collection from Pilton, and another in my Collection from Ashhill Quarry.

Remarlss.-The figured specimen is indistinct, especially in consequence of its having irregular ridges assumed from some other organism on which it was parasitic. Davidson ${ }^{1}$ notes that the free valves of the Carboniferous Craniæ are sometimes similarly marked. The broad marginal concavity seems to indicate a massive shell, and the concave marks in the cast show that in the shell the muscle-scars were very convex.

In 1896 I referred this shell to Craniellic Meduanensis, Ehlert ; ${ }^{2}$ I am inclined now to think that there are probably not sufficient grounds for this identification; the muscular impressions appear to be smaller and differently shaped, and there appears something in the nature of a border. Moreover, Mons. Ehlert, judging from a photograph submitted to him, regards it as a Craniella of the group of Meduanensis, but distinguishable by its contour, the situation of the muscles, and the position of the summit.

To the Carboniferous Crania quadsata, $\mathrm{M}^{\circ} \mathrm{Coy}, \mathrm{sp} .{ }^{3}$ it also appears somewhat similar; but it is distinguisher by the anterior position of its vertex and its occlusor scars, and by the more transverse shape of its divaricator scars.

Of Crania proavia, Goldfuss, ${ }^{4}$ I have only been able to find figures. and descriptions of the lower or fixed valve, and have therefore been unable to compare it. In shape it would seem to have been more rectangular and transverse."

1 1861, Davidson, ' Brit. Foss. Brach.,' vol. ii, pt. 5, p. 195.

z 1888, Echlert, 'Bull. Soc. Etud. Sci. Angers,' (1887), p. 38, pl. x, figs. 1-1 $g$.

3 1844, M'Coy, 'Synops. Carb. Foss. Irel.' p. 104, pl. xx, fig. 1.

4 1853, Schnur, 'Palæontographica,' vol. iii, p. 230, pl. xliii, figs. $9 a, b$; and 18il, Kayser, 'Zeitsch. Deutsch. Geol. Gesell.,' vol. xxiii, p. 641, pl, xiv, fig. 6. 


\section{Genus-Crania, Retzius, 1781.}

1. Crania? ricta, n. sp. Plate XXII, figs. $10,10 a$.

1896. Crania Ringens, Whidborne (not Höninghaus). Proc. Geol. Assoc., vol. xiv, p. 376.

Description.-Ventral valve flattish, transversely oval. Divaricator scars rather small, transversely oval, slightly convex, strongly defined, crossed by strong oblique ridges, and situated very near each other and near the centre of the posterior margin. Occlusor scars confluent, forming apparently a long transverse oval prominence, covered with transverse ridges, and situate at about the posterior fourth of the median line. Ventral adjustor (?) scars very small, obliquely oval, situate at the antero-lateral margins of the occlusor scars. Inner surface covered by minute closely-arranged tubercles or granules.

Size.-Length about $14 \mathrm{~mm}$., width about, $19 \mathrm{~mm}$.

Localities.-A single specimen from Pilton is in the Porter Collection.

Remarles.-I am very doubtful about the generic position of this curious fossil, and only place it provisionally in this genus as its unuscle-marks appear not unlike those of some species of Crania. In many ways it seems to be remarkable. The specimen, which is almost flat, and may, I think, be regarded pretty confidently as a ventral valve, shows no signs of having been attached to any other organism. The striation of the muscle-scars is very strong and acute; the divaricator scars are unusually proximate to each other, being less than their own width apart; and the width across the pair is less than one-third the width of the whole shell. The surface at the centre of the occlusor scars is blurred, so that it cannot be seen whether they are fully or only partially confluent. At their anterior corners may be seen two much smaller and less distinct scars, which may perhaps belong to ventral adjustors. The most striking feature of the fossil, however, is the coarse tuberculation of its inner' surface, which conveys the idea, not of being the casts of pores left in a decayed shell-structure, ${ }^{1}$ but of being the original internal face of the shell. This is, perhaps, analogous to the tuberculated border of some species of Crania.

I have been unable to find the description of any species at all approaching this shell; and, though its general resemblance to some more recent Craniæ makes it just possible that it may be included within the limits of the genus, it is far more likely that further specimens will prove the existence of generic or even greater distinctions.

1 But compare 1892, Hall and Clarke, 'Pul. N. Y.,' vol. viii, pt. 1, pl. iv I, fig. 7. 
II. Family-Discinide, Gray, 1848.

1. Genus-Discina, Lamarcle, 1819.

1. Discina nitrda, Phillips, sp. Plate XXII, figs. 11, $11 a, 12$.

1836. Orbicula nitida, Phillips. Geol. Yorks., vul. ii, p. 221, pl. ix, figs. $10-13$.

1865. Discina nitida, Davidson. Brit. Foss. Brach., vol. iii, p. 104, pl. xx, figs. $9-10 a$.

1871. - - ? Kayser. Zeitsch. Deutsch. Geol. Gesell., vol. xxiii, p. 640 .

Size.-Length $23 \mathrm{~mm}$., width $18 \mathrm{~mm}$.

Localities.-In the Museum of Practical Geology is a lower valve from Barnstaple, and two upper valves (the smaller of which was figured by Davidson) from West Angle (Pembrokeshire). In Miss Partridge's Collection is a specimen of each valve from Saunton. I have obtained specimens from Saunton Hotel and the "Laticosta Cave," " Baggy.

Remarks. - The comparison of our specimens with a large series of Carboniferous specimens leaves no doubt of their specific identity. The only differences observable are that the Devonian specimens sometimes are slightly larger and sometimes more elongate and oval, and that the foramen of the lower valve, as seen internally in them, is much smaller than it is as seen externally in the Carboniferous examples, which difference probably is simply due to its character.

In Miss Partridge's specimen of the upper valve, the strong median longitudinal thickening under the apex is more evident than it is in the Yorkshire shells, in several of which, however, it is observable.

III. Family-Lingulide, King, 1850.

1. Genus-Lingula, Bruguière, 1792:

1. Lingula squamiformis, Phillips. Plate XXII, fig. 13.

1836. Livguha squamiformis, Phillips. Geol. Yurks., vol. ii, p. 221, pl. x1, fig. 14.

1865. - - Davidson. Brit. Foss. Brach., vol. iii, p. 105, pl. $x \mathrm{x}$, figs. 11, 12 .

1 "Laticosta Cave" is, of course, not a local name in ordinary use. It is as well to remark again that I have simply used it as an abbreviation to indicate the one spot where (in company with numerous other species) Rh. laticosta has hitherto been found. 
Size.-Length 19 mm., width $14 \mathrm{~mm}$.

Localities.-Very abundant at Sloly Quarries. Specimens have been found near Baggy Point by Mr. Townshend Hall. A single fine specimen from Saunton is in Miss Partridge's Collection.

Remarlis.-The specimens from Sloly sometimes occur in beautiful states of preservation, but are almost always more or less distorted. Occasionally they appear almost circular in shape, and these my friend Mr. Townshend Hall was inclined to separate under the manuscript name $L$. circularis; but, having examined his specimens, I believe that their shape is entirely due to pressure, and that there is no reason to regard them even as a variety of the common form.

On the other hand, I am more doubtful as to the identity of the fine dorsal valve (Pl. XXII, fig. 13) found by Miss Partridge in the Pilton Beds of Saunton. Its almost oblong shape, almost horizontal posterior margin unbroken by the apex, its very convex shoulders, its thin shell, and the five or six radiating lines on the cast in front, seem to indicate that it is at least a marked variation from the form of the species occurring at Sloly.

\section{Crass-BRYOZOA, Ehrenberg, 1832.}

\section{Order-GYMNOLAMATA, Allman, 1856.}

\section{Sub-order-CRYPTOSTOMATA, Vine, 1883.}

Fenestellids are very abundant in the Pilton Beds; but, as usual, their state of preservation is such as not to lend itself to their easy determination. They can in general only be obtained in fragments, crushed and drawn out in different directions, so as to mask their relative dimensions. From the pressure which the fronds have undergone it can rarely be said whether they were originally fanshaped or conical. From the nature of the rock it is impossible to obtain sections. They occur for the most part either (1) in the condition of internal casts when the cells are visible, but too frequently the dissepiments have disappeared, or (2) in that of external moulds, in which case sometimes the cell-mouths may be recognised, but the dissepiments are frequently blurred by the matrix or missing.

Hence specific determination can only be very tentative. There appears to be sufficiently clear evidence of the existence of at least three or four species, but to define them so as to show their differences or their identity with fossils occurring in other localities is almost impossible; and it is not unlikely that if better specimens were obtainable, differences would be found to exist between some specimens which, under present circumstances, it is necessary to place together. 


\section{Family-Fenestellide, King, 1849. \\ 1. Genus-Fenester.ia, Lonsdale, 1839.}

1. Fexestella plebeia, $M^{5}$ Coy. Plate XXII, figs. $14-15 a$; and Plate XXIII, figs. $1,1 a$.

1S41. Fexestella axtrqua? vars. $\beta$ ? and $\gamma$, Phillips. Pal. Fuss., p. 24, pl. xii, figs. $35(d, e ?) f, g$.

1844. - plebeid, M'Coy. Synops. Carb. Hoss. Irel., p. 203, pl. xxix, fig. 3.

1S55. - - - - Brit. Pal. Foss., p. 76.

1879. - - Shrubsole. Quart. Journ. Geol. Soc., rol. xxxv, p. 278.

1881. - - - $\quad$ - Ibid., vol. xxxvii, p. 179.

Description.-Zoarium apparently flabelliform, large. Fenestrules about nine or ten in the length of $10 \mathrm{~mm}$., and thirteen in the width of $10 \mathrm{~mm}$., elongater, oblong. Branches stout, undulating near the base, almost straight in the distal parts, ahout the width of the fenestrules, and divaricating at first irregularly and farther from the base at very regular distances. Dissepiments apparently small and narrow. Non-poriferous surface ornamented with a few strong longitudinal ridges. Mode of increase sometimes near the base by one or two new branches rising from the closed head of a fenestrule, but generally by the simple fission of the branches, which appears to occur at the rate of once in about ten fenestrules, and at the same level in groups of adjoining fenestrules. Cells arranged in two alternating rows, sometimes with a third cell intercalated at the commencement of a branch, pentagonal in longitudinal section, numbering from four to six, generally five, in the length of a fenestrule.

Size.-A fragmentary specimen is $50 \mathrm{~mm}$. long.

Localities.-Poleshill, Wrafton Lane, Pilton, Ashford Strand, Snapper Quarry, Kingscote (near Brushford), Croyde, \&c. It is an abundant species, and is found at most of the Pilton localities, though it is not so frequent in beds where large Brachiopods predominate.

Remarlis.-This appears to be the species described by Pbillips fiom North Devon under the name "Fenestella antiqua, (?), Lonsdale, var. $\beta$ and $\gamma$," though under these varieties he also included the South Devon form, which I have called $F$. fanata, ${ }^{1}$ and from which it differs in its less rapid branching, the larger number of cells to a fenestrule, and other points. $\mathrm{M}^{\circ} \mathrm{Coy}$, in 1855, separated the form found at Petherwyn from the Middle Devonian species, and referred it to his pre-

${ }^{1}$ 1895, Whidborne, 'Dev. Fauna,' vol. ii, p. 165, pl. xviii, figs. 6-10; and pl. xix, figs. $3,4$. 
viously described $F$. plebeia, and it appears to me that with that species these Pilton fossils are identical.

The only point in which Phillips's description does not agree with our fossils is that he figures and describes the non-poriferous face as granular, whereas they show it to be striated. A free specimen, however, from Ironpost has it tuberculated, and though the fossil is obscure, it seems most likely that that feature is due to mineral change acting perhaps on a finely granulated matrix, and may have obliterated the original striation.

2. Fenestella? umbrosa, n. sp. Plate XXII, figs. $16,16 a$; and Plate XXIII, figs. 2, $2 a, 3,3 a$.

Description.-Zoarium large, convex, infundibuliform. Branches undulating, stout, broader than the fenestrules, poriferous on the external face, which is obliquely flattened, and appears to bear a thin sharp median keel. Nonporiferous face with a few very strong longitudinal striæ, of which the central seems strongest, and perhaps forms an incipient keel. Cells two or three (or occasionally even four) to a fenestrule, projecting (?) so as to cause indentations on the sides of the branches. Fenestrules twelve to seventeen in the length of $10 \mathrm{~mm}$., and about twenty-two in the width of $10 \mathrm{~mm}$. Rate of branching about one in seven.

Size.-A doubtful crushed specimen is more than $80 \mathrm{~mm}$. long.

Localities.-In the Barnstaple Athenæum is one specimen from Roborough; in the Woodwardian Musenm two from Barnstaple; in the Museum of Practical Geology one from Croyde and one from the Pilton Beds; in the Porter Collection six from Roborough, Poleshill, and Pilton; and in my Collection one from Croyde Rocks.

Remarls. - These specimens appear clearly to indicate a species distinct from the common Pilton Fenestella plebeia both in general appearance and detail, and distinguished from it by its stouter, more undulating branches, its smaller and narrower fenestrules, its more rapid branching, its cup-like shape, and other points. At the same time the imperfect state of our specimens, which are almost all moulds or casts, makes it hard to say how much weight may be placed on characters and measurements observable in them, and there are some inconsistencies noticeable in them, rendering it not impossible that they include two similar species, which cannot be separated without better material. Thus-

(1) A specimen in the Woodwardian Museum, another in the Museum of Practical Geology, and another in the Barnstaple Athenæum show that the 
zoarium was infundibuliform, either from its developing from a central base or from its sides overlapping each other. In these fossils the poriferous face of the branches is external, and in one of them it appears to show a thin keel.

(2) In a second specimen in the Museum of Practical Geology, however, the poriferous face appears to be upon the concave (or internal) sicle of the zoarium. This fossil is a mould, and is remarkable for having circular cavities, not quite as numerous as the fenestrules, irregularly placed on its branches, which they equal in width. Whether these cavities indicate spines, as in $F$. Lyelli, Dawson, ${ }^{1}$ or ovarian capsules or nodes such as are described in the very similar F'. vera, Ulrich, ${ }^{2}$ does not appear. The specific identity of this specimen must evidently be at present doubtful, unless the appearance of the inner face being poriferous is deceptive.

In the other specimens the number of cells to a fenestrule is sometimes two, sometimes three, while sometimes (unless a dissepiment has been obliterated) it is four. In one or two specimens which-seem to belong to the same species, but which are in a different state of preservation, and perhaps more nearly resemble $F$. plebeia in some points, their number is clearly three or four.

Affinities. - F. nodulosa, Phillips, ${ }^{3}$ appears to be a closely allied form, resembling our typical specimens in the prominence of the cell-mouths, which nodulate the sides of the branches. Possibly its cells were as a rule slightly more numerous, and its fenestrules wider. Among numerous examples of it in the Woodwardian Museum are two which show its frond to be flabellate, as described by $\mathrm{M}^{6} \mathrm{Coy}{ }^{4}$ (though Phillips called it "radiating," and so figured it). For this reason it seems safer to regard it as distinct.

F. oculata, $\mathrm{M}^{6} \mathrm{Coy}^{5}{ }^{5}$ also is very similar, but appears to branch more rarely, to have no keel on the poriferous face, and to be smooth on the reverse. In these points, perhaps, $F$. flabellata, Phillips, ${ }^{6}$ is still nearer, but its branches seem to be slighter, and its fenestrules more regular; it was regarded by Shrubsole as synonymous with $F$. membranacea, Phillips (i.e. Hemitrypa hibernica, M`Coy).

$\mathrm{M}^{\circ} \mathrm{Coy}$ mentions that in $H$. hibernica there are large irregular spines on the inner face. The fact that the external face is poriferous, and other resemblances, may possibly indicate that our species is really a Hemitrypa, but at present there is no direct proof that it is so. The prominence of the pores, at all events, distinguish it from $H$. hibernica as well as from $H$. oculata, Phillips.

1 1879, Nicholson, 'Manual Palæont.,' vol. i, p. 420, fig. 262.

2 1890, Ulrich, 'Geol. Surv. Illinois,' vol. viii, p. 535, pl. xliv, figs. 1, $1 a$; and pl. liv, fig. 3.

3 1836, Phillips, 'Geol. Yorks.,' vol. ii, p. 199, pl. i, figs. 31-33; and 1881, Shrubsole, 'Quart. Journ. Geol. Soc.' vol. xxxvii, p. 183.

${ }_{4}$ 1844, M'Coy, 'Synops. Carb. Foss. Ireland,' p. 203.

5 Ibid., p. 203, pl. xxviii, fig. 15.

6 1836, Phillips, 'Geol. Yorks.,' vol. ii, p. 198, pl. i, figs. 7-10. 
3. Fenestelda laxa, Phillips.

1836. Fenestella Laxa, Phillips. Geol. Yorks, vol. ii, p. 199, p]. i, figs. $26-30$.

1841. - - - Pal. Foss., p. 23, pl. xii, figs. $34 a, b$.

1879. - crassa, Shrubsole. Quart. Journ. Geol. Soc, vol. xxxv, p. 280.

1881. - _ _ _ _ Ibid., vol. xxxvii, p. 186.

Remarks.-Under this name Phillips identifies fossils from Petherwyn and Croyde with those he had before described from the Carboniferous of Yorkshire. His Devonian figure shows fenestrules about $1.0 \mathrm{~mm}$. long by $5 \mathrm{~mm}$. wide.

I have met with no specimens of any Fenestella at all approaching these dimensions.

4. Fenestellea polyporata, Phillips. Plate XXIII, figs. $4,4 a, 5,5 a$.

1836. Fenestella polyporata, Phillips. Geol. Yorks., vol. ii, p. 199, pl. i, figs. 19, 20.

? 1844. - multiporata, MF'Coy. Symopsis Carb. Foss. Irel., p. 203, pl. xxviii, fig. 9.

1879. - Polrporata, Shrubsole. Quart. Journ. Geol. Soc., rol. xxxv, p. 280.

1881. - $\quad$ - $\quad$ - $\quad$ Ibid., vol. xxxvii, p. 185.

Description.-Zoarium composed of very large network, very irregular near the base, but more regular (and rather smaller ?) in the upper parts. Branches much narrower than the fenestrules, sometimes dividing at the same levels. Poriferous face with a blunt angle or keel, and with obliquely flattened (or excavated ?) sides, bearing (close to, but not protruding over, the margin) a row of elevated, elongate, oval cell-mouths, separated by intervals of about half their length. Non-poriferous face rounded (or bluntly keeled ?), roughly granulated (?). Fenestrules oblong, 2 to $4 \mathrm{~mm}$. in length, and about $1 \mathrm{~mm}$. wide; but near the base irregularly ovoid, and sometimes still longer. About eight cells to a fenestrule.

Localities.-A fragmentary specimen, showing the cell-mouths, from the Pilton beds is in Mr. Hamling's Collection, one from Pilton in the Porter Collection, and three from Kingscote, Pouch Bridge, and East Anstey in my Collection.

Remarls.-Carboniferous specimens of $F$. polyporata in the Woodwardian Museum from Hook Head and from Settle are evidently identical with our Pilton examples. In both these cases the stems seem slightly stouter and the fenestrules 
more oval, but probably our specimens might more resemble them if they were not so cloaked by the matrix, which often almost or entirely covers the dissepiments. F. multiporata, $\mathrm{M}^{\circ} \mathrm{Coy}$, is united by Shrubsole with this species, and there certainly seems nothing to distinguish it; the Pilton fossils seem midway between them.

Affinities.-F. quadridecimalis, $\mathrm{M}^{\circ} \mathrm{Coy},{ }^{1}$ would appear to branch more rapidly, and to have thinner branches and much more numerous pores.

Whatever the specimens from Pilton referred by Phillips to his F. laxa may be, their reticulation (as in the Carboniferous type) was very much larger than that of the present species, e.g. in his figure (said to be natural size) it is more than twice the length of that of our fossils, and the stems are wider than the width of our stems and fenestrules together. It could not, therefore, be reasonably regarded as the same species.

\section{Family-Acanthocladiide, Zittel, 1880. \\ 1. Genus-Penniretipora, d'Orbigny, 1849.}

Goldfuss defined his genus Glauconeme ${ }^{2}$ for four of Münster's species belonging to or in the style of Vincularia, and afterwards added a fifth species, G. disticha, ${ }^{3}$ from the Eifel or from Dudley, to which his generic definition was not applicable. The latter species, according to his figure, seems probably congeneric with $G$. bipinnata, Phillips. In 1839 G. disticha was described from Dudley by Lonsdale ${ }^{4}$ in 'Siluria,' but in terms which imply that the Dudley fossil was more akin to Ptilopora than to G. bipinnata, which Phillips in 1841 described from the Pilton beds. In 1849 d'Orbigny ${ }^{5}$ formed the genus Penniretipora, and defined it in terms which, though slight, are consistent with the characters of the present genus. He enumerated eight species, of which probably the first two do not belong to the present genus, and the next four do. Curiously enough he omits G. bipinnata, and places it under M'Coy's genus Ichthyorachis, having possibly mistaken Phillips's drawing of the reverse side for the obverse. In 1884 Vine $^{6}$ formed a new genus, Pinnatopora, with G. bipinnata for its type, and restricted Glauconeme to G. disticha, Lonsdale. In 1890 Ulrich $^{7}$ followed Vine as to

1 1844, M'Coy, 'Synopsis Carb. Foss. Irel.,' p. 204, pl. xxviii, fig. 13.

2 1830, Goldfuss, 'Petref. Germ.,' vol. i, p. 100, and p. 101, note on Vincularia.

3 Ibid., p. 217, pl. lxiv, fig. 15.

4 1839, Murchison, 'Sil. Syst.', p. 677, pl. xv, figs. 12-12d.

5 1849, d'Orbigny, 'Prodrome,' vol. i, p. 45.

6 1884, Vine, 'Report Brit. Assoc.,' 1883 (Southport), pp. 191 and 192 (woodcut).

7 1890, Ulrich, 'Geol. Surv. Illinois,' vol. viii, p. 614. 
Pinnatopora, but considered that $G$. disticha, Lonsdale, should perhaps be called Penniretipora.

Dr. Gregory informed me in 1895 that he considered Pinnatopora a synonym of Penniretipora, and following him I described two doubtful Lummaton species under the latter name.

It is clear from the above that our fossils cannot be called Glauconeme, and that they can be called Pinnatopora.

It seems rather doubtful whether Penniretipora is sufficiently defined to be valid. D'Orbigny's definition is "Two rows of cells on one side; the whole pinniform, with a stem and free lateral branches." It is perhaps allowable to discard the doubtful species he enumerates, and to restrict the genus to those congeneric with G. bipinnata, Phillips; in fact, to treat it as identical with Pinnatopora, and therefore on the score of priority regretfully to regard the latter and neater name as a synonym.

1. Penniretipona bipinnata, Phillips, sp. Plate XXIII, figs. 6 -8.

1841. Gladconeme bipinnata, Phillips. Pal. Foss., p. 21, pl. xi, figs. $33 a-g$.

1844. - - $\quad$ M'Coy. Synopsis Carb. Foss. Irel., p. 199.

Description.-Zoarium pinnate, elongate, generally curved and rambling, sometimes sending forth a second midrib at an acute angle to the original one. Midrib about $\cdot 5 \mathrm{~mm}$. wide near the base, decreasing very slowly in width, striated and perhaps granulated on the reverse side, which appears rounded and possibly rather flattened. Poriferous side with a strong (perhaps nodulated?) keel, and with obliquely flattened sides, each of which has a row of small rounded cellmouths, which appear to project rather forward, and to be thickened internally. Cells oblong and elongate longitudinally, with thin walls, numbering two on the midrib to each branch. Lateral branches starting from the centre of the sides of the cells, set at an angle of about $70^{\circ}$ to the midrib, free, straight, subcylindrical, sometimes $3 \mathrm{~mm}$. long, about half the width of the midrib and about two-thirds the width of the intervals between them, with rounded extremities, and containing two rows of from six to ten alternating cells; from fourteen to eighteen branches occupying a length of $10 \mathrm{~mm}$. on the midrib.

Size.-A defective but longitudinally stretched specimen is $35 \mathrm{~mm}$. long.

Localities.-Saunton Point, Croyde, Upcot Arch Quarry, Poleshill, Bradiford, Frankmarsh, Top Orchard, Brushford. It appears to be of frequent occurrence.

Remarks. - Though from the state of preservation it is hard to be sure of its exact character and dimensions, this species seems to have abundant distinguishing 
marks, e.g. the regularity with which the branches start from the centre of every second cell on the midrib, their angle and length, and the serpentine general form. The divarication of the main stem itself is rare, and I have not observed any specimen in which it occurs more than once. The angle thus formed is curvilinear, and is generally much less than that of the secondary branches; while the new midrib immediately bears similar lateral branches, though probably at first they are not so long as those on the old. The secondary branches alternate with each other, though they sometimes seem nearly level. The dimensions seem to vary a good deal in different specimens.

Affinities.-Glauconeme pluma, Phillips, sp., ${ }^{1}$ appears from the figures to have longer and slighter branches, and more cells on the midrib between them.

In $G$. pulcherrima, $\mathrm{M}^{\circ} \mathrm{Coy},{ }^{2}$ the habit seems very different, the cell-mouths more central, and the lateral branches " regularly attenuate." In $G$. gracilis, $\mathrm{M}^{\circ} \mathrm{Coy},{ }^{3}$ the cell-mouths are much larger and nodulate the sides, and the branches are much broader than the intervals, but in some respects it bears much likeness to our species. None of the American species described by Ulrich in the eighth volume of the 'Geol. Surv. Illinois' at all resemble it.

G. stellipora, Young and Young, ${ }^{4}$ is much more irregular, and has stellate cellmouths; nor do any of the other species described by those authors ${ }^{5}$ appear to approach the present form.

\section{Penniretipora virgata, n. sp. Plate XXIII, figs. 9, $9 a$.}

Description.-Zoarium small (?), slight, loosely ramose, consisting of a midrib, from which occasional lateral branches start at an angle of about $50^{\circ}$, which in their turn appear to bear similar and similarly set minor branches. Midrib slight, about $\cdot 25 \mathrm{~mm}$. wide, straight, slightly tapering. Reverse face rounded, smooth or minutely striated (?). Poriferous face sharply keeled, obliquely flattened on the sides. Cells in two rows, triangular in longitudinal section. Lateral branches few, unequally distant, slight, sometimes about $4 \mathrm{~mm}$. long, with central keel and two rows of cells, and apparently tapering to a subacute point. Numerous (from five to ten ?) cells on the midrib in the intervals between the lateral branches. Intervals unequal, and frequently about $2 \mathrm{~mm}$. in length.

Size.-A specimen (which is probably a fragment) measures $6 \mathrm{~mm}$. long.

1 1836, Phillips, 'Geol. Yorks.,' vol. ii, p. 199, pl. i, figs. 13-15.

2 1844, M‘Coy, 'Synops. Carb. Foss. Irel.,' p. 199, pl. xxviii, fig. 4.

${ }^{3}$ Ibid., p. 199, pl. xxviii, fig. 5.

4 1874, Young and Young, ‘Quart. Journ. Geol. Soc.,' vol. xxx, p. 682, pl. xl, figs. 5-11.

5 1876, Iidem, 'Proc: Nat. Hist. Soc. Glasgow,' vol. ii, pt. 2, p. 325; and 1879 ? vol. iv, p. 354. 
Localities.-There is a specimen from Croyde Bay in my Collection, and three slabs containing several specimens from Top Orchard in the Woodwardian Museum.

Remarks.-This little species seems rare, but from its slightness it may easily have been overlooked. It is very different from $P$. bipinnata, and I am not aware of any species which it at all resembles. The very large and variable number of cells between adjacent branches, the acuteness of the angle at which the branches are set, the repetition of branching in the lateral branches, and the greatness of the width of the intervals compared with the width of the branches, as well as possibly the shape of the cells, appear to be distinguishing features.

The pieces I have seen are very small, but it is possible that they are only fragments from larger specimens.

\section{Family-Streblotrupide, Ulrich, 1890.}

"Zoaria variable. Zoœcia with primitive portion subtubular or tubular; apertures subcircular, often truncated posteriorly, surrounded by a slightly elevated rim. Front or outer portion of cell, back of the aperture, simply depressed, or with from two to twelve or more small pits. Diaphragms wanting" (Ulrich). ${ }^{1}$

\section{Genus-Streblotrypa, Uliich, 1890.}

"Zoaria ramose, slender, solid. Zoœcia radiating from an imaginary axis, with primitive portion long, tubular; or from a linear axis, when they are somewhat shorter. . . A Apertures regularly elliptic or truncated at the posterior margin, surrounded by a slight peristome, and within this sometimes a narrow sloping area; arranged usually in rather regular longitudinal series. Just back of the aperture, occupying the depressed front of the cell, are from one to twelve small pits, which, when numerous, are arranged in two or three rows. Very small acanthopores occasionally present" (Ulrich, ${ }^{2}$ abbreviated).

\section{Streblotrypa Gregori, Whidborne. Plate XXIII, figs. 10, 10 a.}

1896. Streblotrypa Gregorit, Whidborne. Proc. Geol. Assoc., vol. xiv, p. 376.

Description.-Zoarium cylindrical, small, with strong, acute, elevated, undulating, longitudinal ridges dividing the cell-areas. Areas elongate, irregularly

1 1890, Ulrich, 'Geol. Surv. Illin.,' vol. viii, p. 402.

2 Ibid., p. 403. 
fusiform, concave, with a large, probably circular cell-mouth, behind which are three or four smaller pits or mesopores.

Size.-Length of fragmentary specimen $9 \mathrm{~mm}$.; breadth about $1 \mathrm{~mm}$.

Locality. - A slab containing two specimens from the Pilton beds is in Mr. Hamling's Collection.

Remarls.-The specimens, though in many respects good, are rather difficult to make out in exact detail. As far as can be judged from external appearance, they belong undoubtedly to Streblotrypa, but it is not easy to say whether the smaller pores are only situated on one side of the aperture or on both.

As both our specimens are broken pieces, it cannot be seen whether it is, as most species described by Ulrich, a branching form.

\section{Family-RHabdomesontide, Vine, $1883 .^{1}$}

\section{Genus-Reabdoneson, Young and Young, 1874.}

Of this genus Ulrich ${ }^{2}$ says that it only differs from Rhombopora in having a solid axial tube. Rhombopora he thus defines (abbreviated):- "Zoaria slender, ramose, solid. Zoœcia with thick-walled vestibules. Apertures in diagonally intersecting or longitudinal lines. Strong acanthopores at angles of junction, and more numerous smaller spines generally occupying the summit of the ridge-like interspaces between the subelliptical apertures. Diaphragms sometimes present in the axial regions."

Elsewhere Ulrich notes the close resemblance between the Rhabdomesontidx and the Batostomellidx, tracing passages through kindred species in both families.

I feel in great doubt as to which of these two families the species described below-the Millepora gracilis, Phillips-belongs.

It appears (as far as can be seen without the aid of sections) exactly to agree with the above definition of Rhabdomeson, except that it seems clearly to possess mesopores. In one of the specimens three or four subsidiary cells, chiefly at the corners, are distinctly seen, and these must, I think, be probably regarded as mesopores, and not as acanthopores, while less clear indications of them are visible in one or two other specimens. In the latter, again, are seen prominences which appear in every way identical with the acanthopores and spines described by Ulrich in Rhombopora. Besides Phillips's species we find a second form of

1 Ulrich (loc. cit.infra) states that the primitive cell is tubular, that hemisepta are usually present, and that there are no mesopores.

2 1890, Ulrich, ' Geol. Surv. Illin.,' vol. viii, pp. 401, 402. 
Polyzoa whose exterior is distinguished by the much greater distance of its cellmouths. Belonging to one of these two species (it is not easy to say which) are sometimes found natural casts and sections. In a few instances the latter are along the centre, and these show clearly a strong cylindrical central tube or axis from which the cells arise-that is, have the distinguishing mark of Rhabdomeson.

The history of the genus Rhabdomeson is as follows:-Young and Young ${ }^{1}$ described a Carboniferous species which they referred (with one expression of uncertainty) to Phillips's M. gracilis thus (abbreviated) : "Stem slender, cylindrical, branching perpendicularly, having a hollow axis or thin calcareous tube with cells ranged round. Apertures oval in funnel-shaped depressions, divided by tuberculated ridges. Tubercles (or in good specimens spines) four, situated at the angles, with sometimes smaller between. Cells conical, turning upwards and outwards, separated at their apex by a thin wall which thickens outwardly, so that the mouths are separated by one-third the diameter of the cell-cavity. Spines solid, but showing a central pit when worn." They name the genus, but leave its characters to be inferred from the species.

That the pits in this description correspond with the subsidiary cells seen in our specimens is possible, but, it seems to me, doubtful. Unless they do, Young and Young's Carboniferous species cannot be congeneric with ours, and in any case can only retain its specific name, if ours, which is Phillips's original species, proves to belong to a different genus.

For the present it seems best to refer the Pilton species provisionally to Rhabdomeson, as, with the exception of this difficulty of the character of the minute pores, it is probable that it fulfils the requirements of that genus.

1. Rigabdomeson? gracile, Phillips, sp. Plate XXIII, figs. 11-15a.

1841. Mrllepora gracilis, Phillips. Pal. Foss., p. 20, pl. xi, figs. $31 a, b$.

? 1874. Rrabdomeson gracrie, Young and Young. Ann. Mag. Nat. Hist., ser. 4, vol. xiii, p. 335, pl. xvi, figs. B 1-6.

? $1875 . \quad-\quad-\quad$ Young and Young. Ibid., vol. xv, p. 333.

?1884. - - Vine. Report Brit. Assoc., 1883, p. 205.

Description.-Zoarium small, straight, cylindrical. Axis strong, cylindrical, about one-eighth the width of the zoarium. Cells elongate, tubular, rising obliquely from the branches at a greater or less angle, and with their vestibules recurved, so as to become approximately horizontal. Interior of cells unknown.

1 1874, Young and Young, ‘Ann. Mag. Nat. Hist.,' ser. 4, vol. xiii, p. 335. 
Surface with circular or longitudinally oval cell-mouths set in quincunx, separated from each other by intervals less than their diameters. Interspaces elevated, ridge-like, bearing nodes or acanthopores on their summits, and three or four mesopores (?) situated generally at the corners of the apertures. About three cell-mouths to $1 \mathrm{~mm}$.

Size. - A specimen measures $20 \mathrm{~mm}$. long and $1 \mathrm{~mm}$. wide.

Localities.-Top Orchard Quarry, East Anstey, Ironpost.

Remarks. -The difficulties in describing this and the following species have been stated above, and the descriptions must be taken as tentative in some respects.

There is, I think, no doubt that this species is the original Millepora gracilis of Phillips. His enlarged figure accurately represents the appearance that rather worn specimens retaining the surface assume.

If the Carboniferous Rh. gracile of Young and Young is congeneric, that form would require a new specific name, as it is certainly not identical.

To the above description it may be added that in some of the natural cylindrical sections showing the central tube there seems a point at which the cells become horizontal, and beyond which they are set obliquely with a slope in the opposite direction to that upon the other side of it. This would appear to be a point of origin, and if so the organism would probably be free. In these specimens I have not seen any signs of branching.

Affinities.-Carboniferous specimens of "Rhabdomeson gracile" in the Woodwardian Museum, from Hook Head and other localities, appear to me to be totally unlike our fossils; their cells are in perpendicular ranges, their acanthopores are very prominent and bead-like, and I can see no trace of anything like mesopores. Rhombopora dichotoma, $\mathrm{M}^{\circ} \mathrm{Coy}, \mathrm{sp} .{ }^{1}$ and Rhabdomeson rhombiferum, Phillips, sp., ${ }^{2}$ as represented by specimens in the same Museum, seem quite different in structure from the present fossils. On the other hand, Rhabdomeson interporosum, Phillips, sp., ${ }^{3}$ appears, from its specimens, to be very much more like them; it seems to have mesopores, or at least subsidiary cells or pits of the same character as those in our fossils, and may certainly be regarded as belonging to the same genus.

1 1844, M'Coy, 'Synopsis Carb. Foss. Irel.,' p. 198, pl. xxvii, fig. 15.

2 1836, Phillips, 'Geol. Yorks.,' vol. ii, p. 199, pl. i, figs. 34, 35.

3 Ibid., p. 199, pl. i, figs. 36-39. 
2. SUB-ORDER-TREPOSTOMATA, Ulich, 1882.

I. Family-Batostomelidide, Ulrich, 1890.

1. Genus-Leioclema, Ulvich, 1882.

1. Leioclema? distans, Whidborne. Plate XXIII, figs. $16,16 a$.

1896. Rhabdonison? distans, Whidborne. Proceed. Geol. Assoc., vol. xiv, p. 376.

Description.-Zoarium small, ramose, cylindrical. Zoœcia small, elongate, oval, separated from each other by interspaces considerably greater than their diameters. Interspaces apparently flat, and occupied by numerous thin-walled mesopores (?) Cell-mouths possibly covered with convex opercula (?).

Size.-A specimen measures $11 \mathrm{~mm}$. long, and $1 \mathrm{~mm}$. in the width of the branch.

Localities.-In the Woodwardian Museum are two slabs containing two specimens from Top Orchard, and in Mr. Hamling's Collection two slabs with two or three specimens from rocks to the north-west of the "Laticosta Cave," Croyde.

Remarks. - This species is similar in habit to $R$. gracile, but is clearly distinguished from it by its smaller and much more distant cell-mouths, and by the existence of numerous small mesopores round the larger cells, evidence of which is seen in the Woodwardian specimens, which are in the form of moulds, and which also show slight ridges dividing the cell-areas.

In the Croyde specimens, on the other hand, which retain the surface, though probably worn, the cell-mouths form small convex projections, which may perhaps mean that they were covered by opercula. In parts of the latter specimens which are worn to form rough natural sections the cells appear to be short conical tubes, rapidly curved, and enlarged in the mature part or vestibule.

In this species (assuming that sections like that shown on Pl. XXIII, fig. 15, do not belong to it) we do not appear to have any approach to Rhabdomeson, while it presents a general likeness to Batostomella; its external resemblance to Leioclema gracillimum, Ulrich, ${ }^{1}$ is so strong, that it seems advisable to refer it provisionally to that genus.

The genus Hyphasmopora, Etheridge, ${ }^{2}$ certainly appears to have much in common with it. Its cells are in vertical lines, separated by a cancellated network

1 1890, Ulrich, 'Geol. Surv. Illinois,' vol. viii, p. 429, pl. lxxv, figs. 6-6 b.

2 1875, J. Etheridge, jun., ‘Ann. Mag. Nat. Hist.,' ser. 4, vol. xv, p. 43, pl. xiv, figs. B 1-4. 
of irregularly formed pores, but cell-mouths are almost entirely absent from the reverse side, - a feature which does not appear from our specimens, though it is quite possible that it may exist.

\section{Family-Fistuliporide, Ulrich, 1882.}

1. Genus-Fistulipora, $M^{\circ} \mathrm{Coy}, 1849$.

1. Fistulipora? sp. Plate XXIII, figs. 17, 17 a.

? 1841. Manon cribusun, Phillips. Pal. Foss., p. 17, pl. ix, fig. 26.

1896. Berentcea irregularis?, Whidborne. Proc. Geol. Assoc., vol. xiv, p. 376.

Description.-Zoarium forming a very thin expansive layer, in which no signs of attachment to other organisms have been discerned. Zoœcia short, stout, cylindrical, set perpendicularly to the face of the layer, divided by walls which, though appreciably thick, are much thinner than the diameter of the cells, and crowded together in such a way that irregular circular patterns may frequently be traced in the mass. Ten zoœcia occupying a distance of about $5 \mathrm{~mm}$. Cellmouths possibly contracted.

Size.-A specimen is $40 \mathrm{~mm}$. long and more than $10 \mathrm{~mm}$. wide; it seems about $1 \mathrm{~mm}$. thick.

Localities.-There is a specimen in the Porter Collection from Poleshill, and another in my Collection from Saunton Hotel.

Remarks. - Of these fossils little can be said, except that they appear to be so similar in pattern to Berenicea irregularis, Lonsdale, ${ }^{1}$ that it is possible that they may prove to be akin. The same irregular arrangement appears to be observable in the Silurian species. I have observed a very similar fossil in the Ilfracombe beds.

Whether they are the same as the very similar fossil which Phillips described from these beds as Manon cribosum, Goldfuss, ${ }^{2}$ I am uncertain, as his figure shows a texture which, though much finer than that in Goldfuss's figure, is much coarser than that of our specimens. As I have only seen these little fossils in the condition of casts it has been quite impossible to arrive at their true character, and it therefore seems best to leave them for the present in the genus Fistulipora, which was formed by $\mathrm{M}^{\circ} \mathrm{Coy}$ " to include Manon cribosum, Goldfuss, and some new species." s One of our specimens shows vacant spots, which may, or may not, represent monticules. 
2. Fistulipora? sp. Plate XXIII, figs. 18, 19.

Description.-Zoarium formed of a very thin layer encrusting crinoid stems and other organisms. About twenty-five cells in a distance of $5 \mathrm{~mm}$. Cells probably opening obliquely.

Size.-A specimen measures about $20 \mathrm{~mm}$. lọng and $10 \mathrm{~mm}$. wide.

Localities.-A specimen from Frankmarsh is in the Barnstaple Athenæum, one from Barnstaple in the Woodwardian Museum, and one from Saunton Hotel in my Collection. I have observed other specimens, and it does not appear to be uncommon.

Remarles. - Whether this is more than a young stage or dwarfed encrusting variety of the last species I am unable to say. In the specimens before me the cells seem distinctly smaller and more oblique near the margins of the layer, and it therefore seems better to keep them apart, at least for the present.

\section{ANNULOSA.}

\section{Order-TUBICOLA, Ouvier (?).}

\section{Genus-Cornulites, Schlotheim, 1820.}

Without expressing an opinion as to the systematic position of these fossils, except offering the remark that their resemblance to Spirorbis, as may be seen by the figures given by Hall, seems favorable to their being placed among the Tubicolous Annelids, it may be observed that their presence in the Pilton Beds is not favorable to theory that they are "horns of Cystideans," as no Cystideans occur in these beds.

1. Cornulites devonianus, Whidborne. Plate XXXVII, figs. 1-3.

1896. Cornolites devoninnus, Whidborne. Proc. Geol. Assoc., vol. xiv, p. 377

Description.-Tubes conical, solitary, straight curved or irregularly flexuous, generally elongate, but occasionally short and rapidly increasing; apparently unattached. Surface (of cast) crossed by very strong annulations, which usually are broad (about three in a length equal to the width), nearly regular and in the form of consecutively truncated inverted cones, but sometimes are very irregular, close and confluent. 
Size.-Length from 3 to $12 \mathrm{~mm}$.

Localities.-In the Barnstaple Athenæun is a specimen from Top Orchard; in the Porter Collection five from Pilton, one from Roborough, and one from Poleshill; and in my Collection one from Pouch Bridge, one from Kingdon's Shirwell, and one from Laticosta Cave, Baggry.

Remurls.-Our specimens being chiefly casts do not show any cellular structure, and only in two cases faint signs of longitudinal striation. From their form and general character, however, there can be no doubt that they belong to the genus Cornulites. In the smaller specimens the annulations are, as a rule, fairly regular (though occasionally they appear to vanish over a portion of the circumference) and the shape is a very elongate cone, sometimes straight, sometimes recurved. In one or two specimens, which are larger, the annulations have become very irregular and confused, the shape is a broader cone, and there is a more rapid expansion near the mouth or broader end. I have not observed any signs of their being attached to other bodies, but it is most likely that they were so attached by the apex.

From the Silurian C. serpularius, Schlotheim, ${ }^{1}$ our fossils are widely different in size and the width of their annuli, and they also appear to differ in the same respects, though in a less degree, from C. proprius, Hall, ${ }^{2}$ and the other species described by him. A comparison of Hall's figures ${ }^{3}$ is interesting, as they show that the same variations with age occurred in his species as in ours.

\section{ECHINODERMATA.}

\section{Class-ECHINOIDEA, Breyn, 1732.}

\section{Sub-class-PALECHINOIDEA, Zittel, 1890.}

1. ORDER-PERISCHOËCHINID $\approx, M^{\circ} \mathrm{Coy}, 1849$.

I. Family-Meiconiride, Zittel, 1890.

1. Genus-Lepidesthes, Meele and Worthen, 1868.

"Subspheroidal; interambulacral areas narrow, with plates imbricating from below upwards, and from the middle outwards; ambulacral areas very wide, composed of numerous small pieces scarcely differing in form, and all imbricating from above downwards, the lower edges of each lapping upon the next series

1 1820, Schlotheim, 'Petrefact.,' p. 378, pl. xxix, fig. 7.

2 1888, Hall, 'Pal. New York,' vol. v, pt. 2, Suppt., p. 19, pl. cxvi, figs. 1-21.

3 Ibid., pls. cxv, cxvi, cxvi $a$. 
below; ambulacral pores two in each piece, and nearly central. Anal opening and apical disc unknown. Jaws well developed. Entire surface ornamented with numerous very small granules of uniform size, probably for the articulation of minute spines, as in Palæchinus."

The species described below seems so nearly to fall within the limits of the above description that in the crushed condition of our fossils it hardly seems safe to form a new genus for it at present, especially as the generic definition gathered from a single specimen of a single species may perhaps require some modification.

The chief particulars in which our species disagrees are-(1) that the interambulacral plates bear six or eight irregular small tubercles of different sizes; (2) that the ambulacral plates seem smooth; and (3) that there seem to be very numerous minute acicular spines, mixed with a comparatively few larger ones. It must here be distinctly observed that it fails to meet accurately the requirements, not only of the genus, but of the family.

Its imbricated plates, together with their large numbers in both areas, separate it from all the other genera of this order mentioned by Zittel except Pholidocidaris, ${ }^{2}$ which differs among other things in the much larger comparative size of the adambulacral plates, and in many of the interambulacral plates bearing a large central tubercle.

Perischodomus ${ }^{3}$ has only two rows of ambulacral plates in each area.

Hybechinus, of Meek and Worthen, ${ }^{4}$ chiefly differs from Lepidesthes in having the imbrication exactly opposite, i.e. from above downwards in the interambulacral zones, and from below upwards in the anbulacral (so that their lower part is covered). Its interambulacral plates are rhombic instead of being hexagonal, as in our species. The granules seem very much more minute; they are not visible in the drawing of $H$. spectabilis, Worthen and Miller, ${ }^{5}$ the type species.

1. Lepidesthes? devonicans, Whidborne. Plate XXIV, figs. $1-2$; and Plate XXV, figs. $3 a-f$.

1896. Lepidesthes? Devonicans, Whidborne. Proc. Geol. Assoc., vol. xiv, p. 376.

Description.-Test very large, regular, composed of very numerous plates, which are approximately equal in height and breadth. Interambulacral areas with

1 1868, Meek and Worthen, 'Geol. Surv. Illinois,' vol. iii, p. 522 (slightly abbreviated).

21873 , Ibid., vol. v, p. 510.

3 1849, M‘Coy, 'Anv. Mag. Nat. Hist.,' ser. 2, vol. iii, p. 254.

4 1883, Worthen and Miller, 'Geol. Surv. Illinois,' vol. vii, p. 331. 1Ss3, ibid., p. 332, pl. sxxi, figs. $5 a-d$. 
about seven rows of subhexagonal plates, which appear to be of uniform size in all the rows at the same level, and to be imbricated from below upwards. Interambulacral plates about $2 \mathrm{~mm}$. in diameter, minutely granulated over their whole surface, and ornamented by (1) an irregular circle of five small unequal tubercles or warts, which have a minute perforated mamelon on a sloping elevated boss, and are bordered by a minute linear furrow or areola, and (2) several much smaller warts of various sizes. Spines very numerous (or crowded), acicular, sometimes $5 \mathrm{~mm}$. long, covered with microscopic longitudinal grooves, and slightly expanded at the base, which seems to be concave with a slight median projection. Ambulacral areas with numerous (probably about seven) rows of rather smaller and narrower plates (apparently of a rather wide curvilinear polygonal shape), each of which bears close-set twin ambulacra, and which generally seem smooth, though small tubercles are observable upon a few of them. Lantern-apparatus composed of very large, smooth, wedge-shaped bones, some of which are 12 or $15 \mathrm{~mm}$. long.

Size.-A flattened distorted specimen is about $120 \mathrm{~mm}$. long and $55 \mathrm{~mm}$. wide.

Localities. - A large flattened example (on two slabs split horizontally) from "the Pilton Beds, North Devon," is in the Museum of Practical Geology, and another (almost entirely hidden by the matrix), from Croyde, is in my Collection.

Remarlis.-The best of these specimens appears to be an almost complete test, but, having been flattened and then split through the centre, the plates have become so confused that it is almost impossible to decipher it accurately, though most of its characters may be said to be nearly clear. Occasionally the hexagonal form of an interambulacral plate is evident; and their imbricating character is undoubted, though it is not so easy to be sure of the direction of the imbrication. These interambulacral plates do not all seem tuberculated, but all are granulated. Their tubercles are clear and vary in size, but they are always small : though irregularly placed, a roughly circular arrangement of the five largest may often be traced. In one part seven plates at least may be counted across the area. The ambulacral plates, again, are obscure in shape, but they appear sometimes rather broader than high, and irregularly polygonal or pentagonal, with some concave sides. They do not, as a rule, show any ornament or granulation, but in one or two cases spiniferous tubercles can be seen upon them. They evidently imbricate, and the imbrication seems probably to be in the opposite direction to that of the interambulacral plates. The ambulacra are large and very distinct, and perhaps are obliquely arranged, but this is not certain. Judging from the casts of the ambulacra, the test must have been thin. The spines, though always very small, seem to vary in length and thickness.

From the present dimensions of our crushed specimens we may conclude that 
the test in its original shape could hardly have been less than three inches in diameter, and possibly was considerably larger.

Affinities.-Lepidesthes Coreyi, Meek and Worthen, ${ }^{1}$ differs in having much smaller and more numerous (eighteen to twenty-five) warts, which are all equal in size, both on the interambulacral and ambulacral plates. Its test also appears to have been much smaller.

\section{Family-Archeocidaride, $M^{5} \mathrm{Co} y, 1855$.}

- 1. Genus-Protocidaris, gen. nov.

Interambulacral plates with a small central perforated tubercle, consisting of a minute mamelon on a base without a distinct areola or bounding ring round the base, and with five or six minute subsidiary tubercles. Spines acicular, finely striated.

The central perforated tubercles show that the species described below may be regarded as belonging to the family Archxocidaridx, but the absence of a "ring or slight projection round their base" excludes it from the genus Archrocidaris, in which genus, moreover, the spines are (with very rare exceptions) covered with thorny points.

Neither does it appear referable to Eocidaris, Desor, ${ }^{2}$ though it agrees with it in the absence of the bounding ring or slight projection. In that genus as described by Hall, ${ }^{3}$ and in E. Drydenensis, Vanuxem, sp., ${ }^{4}$ it is stated that there is only one spine to each plate, whereas our species wonld seem to have had several subsidiary spines. Desor, moreover, in his original description, states the spines to be spinuliferous, whereas ours are simply striated.

In Lepidocidaris, ${ }^{5}$ which appears to be a genus founded by Meek and Worthen for their Eocidaris? squamosus, ${ }^{6}$ the central tubercles appear very much larger, bordered by a groove, though without a bounding rim, and surrounded on the margins of the plate by crowded granules; its spines, however, are similar in shape to ours.

There seems, therefore, only to remain the genus Lepidechinus, ${ }^{7}$ with which

1 1868, Meek and Worthen, 'Geol. Surv. Illinois,' vol. iii, p. 525, woodcut A.

2 1858, Desor, 'Synopsis des Échinides Fossiles,' p. 155.

3 1867, Hall, 'Twentieth Rept. Regent's Univ. N. Y.,' p. 297.

4 Ibid., p. 298.

5 1873, Meek and Worthen, 'Geol. Surv. Illinois,' vol. v, explan. of pl. ix.

6 Ibid., p. 478, pl. ix, figs. $15 a-g$.

7 1861, Hall, 'Desc. N. Sp. Crinoidea,' Preliminary Notice, p. 18. 
our species may be compared. In Hall's definition of the genus and of the type species (L.imbricatus) no tubercles are mentioned. In his second species, L. rarispinus, ${ }^{1}$ a few of the interambulacral plates bear very much elevated tubercles. The characters of these tubercles are not very evident from the description of the species, but judging from the figure it seems extremely unlikely that they tally with ours.

It therefore is most probable that its genus is distinct, although at present this can be only very imperfectly defined.

1. Protocidaris acuaria, Whidborne, sp. Plate XXV, figs. $1-2 a$.

1896. Eocidaris? aCdaria, Whidborne. Proc. Geol. Assoc., vol. xiv, p. 376.

Description.-Interambulacral plates large, 4 or $5 \mathrm{~mm}$. in diameter (probably sometimes hexagonal in shape), bearing a small central perforated tubercle consisting of a mamelon surmounting a boss, but without any distinct areola, and surrounded by.an irregular circle of five or six minute granules or warts. Spines cylindrical, of various sizes, sometimes being more than $11 \mathrm{~mm}$. long, finely striated longitudinally, but without lateral spicules, and slightly constricted above the base, which is expanded in the shape of an inverted truncated cone. Dental apparatus large, apparently more than $30 \mathrm{~mm}$. in size, some of its ossicles being covered on one side with transverse, and on another with obliquely rugose, markings.

Size.-The test was probably very large, a fragmentary specimen, which shows comparatively few plates, being about $65 \mathrm{~mm}$. in length.

Locality.- In the Museum of Practical Geology are three fragmentary specimens, all probably portions of a single animal, from " East of Barnstaple."

Remarles. - The only specimens of this species with which I am acquainted yield-but very imperfect information about its characters. 'They consist of the casts of confused groups of plates and spines, the latter having helped to obscure the shape of the former. I have not recognised any ambulacral plates among them, and it is therefore probable that the ambulacral areas occupied a comparatively small portion of the test. Though the margins of the plates are for the most part obliterated, their general size and character are clear, and, with the following exception, I have not been able to recognise anything very similar to them in the descriptions of recorded species.

Cidaris lævispina, Sandberger, ${ }^{2}$ which Desor ${ }^{3}$ refers to Eocidaris, though

1 1867, Hall, 'Twentietli Report Regents Univ. N. Y.,' p. 295, pl. ix, fig. 10.

2 1856, Sandberger, 'Verst. Rhein. Nassau,' p. 382, pl. xxxv, figs. 2-2 $b$.

3 1858, Desor, 'Synopsis Echinides Fossiles,' p. 156, pl. xxi, figs. 18-22. 
remarking that it perhaps differs generically from another species which he places beside it, seems very nearly akin to the present form, but its subsidiary tubercles are very much larger and more regularly placed.

\section{Class-ASTEROIDEA, Grey, 1840.}

\section{Order-ENCRINAS'I'ERIA, Brom, 1860.}

1. Genus-PaLeaster, Hall, 1852.

1. Paleaster longinanos, Whidborne. Plate XXVI, figs. $1-4$; and Plate XXIX, fig. 3 .

1896. Paleaster longimands, Whidborne. Proc. Geol. Assoc., vol. xiv, p. 376.

Description.-Upper surface of body of medium size, convex, without any expanded disc, and with five very long slightly tapering arms. (Madriporiform tubercle unobserved.) Surface covered with polygonal or subquadrate tesselated plates, each bearing a large rounded central tubercle. Plates arranged in from seven to five longitudinal rows on the arms, the central row being the largest, and the lateral rows smaller, the plates gradually diminishing from the centre.

Under surface having narrow transverse ambulacral plates with large grooves, bounded by a row of large transverse adambulacral plates which alternate with a row of smaller marginal plates.

Oral plates small, triangular. Arm-plates in more than fifty transverse rings.

Size.-Length of a single arm about $20 \mathrm{~mm}$. ; hence the animal, if regularly expanded, would measure about $35 \mathrm{~mm}$.

Localities.-In the Museum of Practical Geology are four specimens labelled "Park, near Braunton," "Braunton Down," "Baggy Point," and "North Devon." In the Woodwardian Museum are two specimens from Top Orchard; in the Porter Collection one from Pilton; and in my Collection one from Top Orchard.

Remarlss.-I have repeatedly searched these specimens, which are all casts, for a madriporiform body, but, probably from their state of preservation, have not been able to discover anything resembling one. The external skeleton of the arms seems generally to consist of a large central plate, having on each side a smaller proximate plate, three very small lateral plates, a larger marginal plate, and a still larger transverse adambulacral plate, so that the ring is composed normally of thirteen rows, but occasionally an additional row seems to be present. The shape of the plates of the body and back, their bevelled margins, flat surfaces, 
and large central oval bead-like tubercles are well shown in one of the specimens in the Museum of Practical Geology. The oral plates are not distinct; they are probably either very small, or have their surface divided by a depression. The arms seem unusually long for this genus; in two of the specimens (Pl. XXVI, fig. 4, and Pl. XXIX, fig. 3) the arms appeared at first sight shorter and more conical, but a slight development of the specimens (after they had been drawn) showed that their arms were really longer than at first appeared, and there seems little doubt that their semblance of shortness is due to their being twisted and covered with matrix.

Affinities.-The length of the arms and the much fewer number and larger size of the rows of plates appear to distinguish this species from $P$. asperrimus, Salter. ${ }^{1}$ From $P$. coronella, Salter, ${ }^{2}$ it seems separated by the absence of a corona, and from $P$. obtusus, Forbes, sp., ${ }^{3}$ and $P$. Ruthveni, Forbes, sp., ${ }^{4}$ by the character of the ornament. Most if not all of the species of Palxaster described by Hall ${ }^{5}$ in his Twentieth Annual Report are distinguished by the much greater shortness of the arms.

Asterias asperula, Ferd. Römer, ${ }^{6}$ seems, on the other hand, to be still slighter in shape, and to have relatively longer arms. From its state of preservation the figures are not easily compared with ours, but the description indicates that there were two alternating central rows of plates instead of a single large central row, as in the present species.

The arms of $P$. Caractaci, Salter, are much shorter, and the surface arrangement quite different.

\section{Order-EUASTERIA, Zittel, 1895 (= Asteriæ veræ, Bromn).}

\section{Genus-Medusaster, Stürtz, 1890.}

1. Medusaster parvus, n. sp. Plate XXXVII, fig. 4.

Description.-Animal minute, with a large round disc and sixteen arms. Disc rather thick, flatly cushion-shaped, and apparently covered by numerous large nodular plates. Angle-ossicula apparently very large and long, leaving in the cast long triangular ridges, which extend from the point of junction of the bases

1 1857, Salter, 'Ann. Mag. Nat. Hist.,' ser. 2, vol. xx, p. 325, pl. ix, fig. 1.

2 Ibid., p. 326.

3 1849, E. Forbes, ‘ Mem. Geol. Surv.,' Decade 1, p. 2, pl. i, fig. 3.

4 Ibid., p. 1, pl. i, fig. 1.

5 1867, Hall, 'Twentieth Ann. Report Regents Univers. N. Y.', p. 283, pl. ix, figs. 1-4.

6 1863, Ferd. Römer, 'Palæontographica,' vol. ix, p. 146, pl. xxiv, figs. $1-5$; pl. xxvi, fig. 6 ; and pl. xxvii, fig. 1. 
of the arms almost half-way to the centre of the disc. Arms rather longer than the width of the disc, slight, composed of rows of few long and level ossicula, bearing on each side at long regular intervals a single large, long, thorn-like spine (which in the fossil is occasionally bent, possibly from accidental causes).

Size.-Total width of specimen $8 \mathrm{~mm}$. (If perfect and untwisted it probably would measure 9 or $10 \mathrm{~mm}$.) Disc $2.5 \mathrm{~mm}$. Arms between 3 and $4 \mathrm{~mm}$. long. Locality.-A single specimen from north-east of Harford Landkey is in Mr. Hamling's Collection.

Remarks.-It was only after the description of the last species was in print that I found this interesting little fossil in a slab sent to me by my friend Mr. Hamling. Though minute, and in such defective preservation that it is impossible to make out the arrangements of its plates, it is sufficiently clear to leave no doubt whatever as to its general character. Its sixteen arms can be definitely counted, and the few long distant spines that margin them are evident, though sometimes they seem curiously bent. The plates of the arms have the appearance of being remarkably long.

Affinities.-This species appears to be congeneric with $M$. Rhenanus, Stürtz, ${ }^{1}$ but is distinguished from it by its small size, its much larger disc, its more numerous arms, and several other particulars.

Helianthaster Rhenanus, Ferd. Römer, ${ }^{2}$ is very much larger, its disc is relatively smaller, the plates of its sixteen arms more numerous and differently arranged, and the spines much more numerous.

\section{Class-OPHIUROIDEA, Wright, 1857.}

\section{Order-OPHIUREA, Zittel, 1879.}

I. Family-Ophio-encrinasterie, Stürtz, 1886.

1. Gemus-Protaster, Forbes, 1849.

Stürtz ${ }^{3}$ and Dr. Gregory ${ }^{4}$ have both pointed out that various species, differing in important particulars from each other, have been referred to this genus, and that it greatly needs revision. While, therefore, until this be done, it may be necessary still to refer species of unlike aspect to it, it is best to remember that neither P. Miltonii, Salter, nor P. Forbesii, Hall, nor P. brisingoides, Gregory, ${ }^{4}$ but

1 1890, Stürtz, 'Palæontographica,' vol. xxxvi, p. 229, pl. xxxi, figs. 34, 35.

2 1863, Ferd. Römer, 'Palæontographica,' vol. ix, p. 147, pl. xxviii, fig. 1.

s 1886, Stürtz, 'Palæontographica,' vol. xxxii, p. 79.

4 1889, Gregory, 'Geol. Mag.,' Decade 3, vol. vi, p. 24, woodcuts 1-4. 
P. Sedgwickii, Forbes, is the type of the true genus Protaster, from which the superfluities will have to be removed.

1. Protaster granifer, Whidbome, sp. Plate XXVI, figs. 5, $5 a, 6,6$ a.

1896. Eugaster aranifer, Whidborne. Proc. Geol. Assoc., vol. xiv, p. 377.

Description.-Animal with a moderately large pentagonal disc, and rather long al'ms, which are slightly fusiform at first, and then taper very slowly to a distant extremity. Upper surface of disc marked by a large impressed stellate corona, which is bounded by elevated sides, and is about half the width of the disc in diameter. Upper and lower surface of disc and upper surface of arms covered with an integument composed of minute convex scales, irregularly scattered among still more numerous and minute granules. Mouth apparently small and central. Oral or buccal plates apparently large, deep, and elongate. Upper surface of arms having (1) two central alternating rows of transverse subhexagonal plates, divided transversely by a linear groove, and (2) an alternating lateral row of slightly convex squamose or imbricating plates, at the lower margins of. each of which are situated one or more short, broad, ovate, slightly curved spines. Under surface of arms with two alternating rows of narrow ambulacral plates, excavated on their outer margins by pores, which are outwardly enclosed by a row of obliquely protruding adambulacral plates, at the outer or lower extremities of which the spines are situated.

Size.-A nearly perfect, but perhaps slightly elongated, arm measures $50 \mathrm{~mm}$. 'The size of the expanded animal was therefore probably about $90^{\circ} \mathrm{mm}$.

Localities.-In the Museum of Practical Geology is a very fine specimen (seen as casts of the upper and lower surfaces) from "the Pilton Beds of North Devon."

Remarks. - Casts taken from the under surface of this specimen and from the under surface of specimens of Protaster Sedgwickii, Forbes, ${ }^{1}$ in the same Museum appear accurately to agree in all points of the arrangement of the arms and plates. The arrangement of the buccal plates appears also to be similar. Hence, as $P$. Sedgwiclii is the type of the genus, it appears that this is a species of Protaster, in spite of the disc having a pentagonal form more in the shape of that of the genus Eugaster, Hall. ${ }^{2}$

From $P$. Sedgwickii it differs in the large size of the corona and many other minor particulars.

1 1849, Forbes, 'Geol. Surv.,' Decade 1, p. i, pl. iv, figs. 1-4.

2 18 67, Hall, 'Twentieth Report Regents University, N. Y.,' p. 290. 
2. Protaster? (Drepanaster) scablosus, Whidbome. Plate XXIX, figs. $1-2 a$.

1896. Protaster scabrosus, Whidborne. Proc. Geol. Assoc., vol. xiv, p. 377.

Description.-Animal small, with long, narrow, regularly tapering arms. Disc probably one-fourth or one-fifth the width of the expanded animal, subcircular, covered on its dorsal surface with comparatively large squamiform overlapping plates, which appear to be subquadrate in shape. Dorsal surface of arms covered with similar, but smaller, squamiform plates. Ventral surface of arms with (1) a double median row of ambulacral plates, excavated at their outer ends by moderately large pores, and (2) a marginal row of elongate arching adambulacral plates, whose proximal ends in part bound these pores, and each of which bears a group of two or three spines. Buccal plates (ten? paired) apparently rather large, giving, in the cast, the appearance of a short-rayed star on the under side.

Size.-A specimen with twisted arms measures $22 \mathrm{~mm}$. One of the arms is about $20 \mathrm{~mm}$. long, so that the expanded animal probably measured about $37 \mathrm{~mm}$. across.

Localities.-There is a good specimen from Croyde in the Barnstaple Athenæum, and another from Braunton Down in the Museum of Practical Geology.

Remarlis. - It-is to be observed that the ambulacral plates in this species distinctly alternate. This appears to be consistent with Forbes's original definition of the genus Protaster; though, from Salter ${ }^{1}$ having described them in P. Miltonii as level (by way of exception), Hall and others seem to have come to regard this as a generic character-Hall, however, questioning it, as in P. Forbesii, Hall, ${ }^{2}$ they slightly alternate. It appears to me, however, that for various other reasons, $P$. scabrosus, together with $P$. Forbesii, with which it appears to be congeneric, will have to be separated from the genus Protaster as defined by Forbes; from the shape of its adambulacral plates it might perhaps bear the name of Drepanaster. ${ }^{3}$

3. Protaster? (Drepanaster) scabrosus, var. Plate XXVII, figs. 1-3; and Plate XXVIII, figs. $1-2 b$.

Description.-Animal small, five-rayed. Disc large, circular, covered with very small plates. Rosette large, subpentagonal. Arms long, rather stout at the base, regularly and rather rapidly tapering, and having on their under side a double alter-

${ }^{1}$ 1857, Salter, 'Ann. Mag. Nat. Hist.,' ser. 2, vol. xx, p. 330, pl. x, figs. 4-4c (cf. p. 325, where " Protaster, nov. gen.," is evidently a misprint).

2 1867, Hall, 'Twentieth Report Regents Unirersity, N.Y.,' p. 293, pl. ix, figs. 5, 6.

3 $\Delta \rho \dot{\pi} \pi u r o v$, a sickle. 
nating row of stout ambulacral plates (probably thirty in number) excavated on their outer margins by large round pores, which are bounded outside by elongate, curving or bent, adambulacral plates. Surface of plates minutely granulated. Oral plates large, wedge-shaped, paired into close connection at their apices.

Size.-An arm measures $28 \mathrm{~mm}$., so that the expanded animal must have measured about $50 \mathrm{~mm}$.

Localities.-In the Museum of Practical Geology are three specimens from Croyde, and one (cast and reverse) from North Devon; in Mr. Hamling's Collection one (cast and reverse) from 'lop Orchard Quarry; and in the Porter Collection an indistinct specimen from Fremington.

Remarles. - While these specimens have much resemblance to those last described, several dissimilarities are to be noted in them. Thus the disc (usually very indistinctly seen) appears much larger and covered by much smaller plates, the rosette seems larger, the arms stouter and more quickly tapering, and the ambulacral plates much broader. In some of the specimens the adambulacral plates appear to have been pushed out of place. At the same time it does not seem certain, in the defective state of our specimens, how much real value these dissimilarities have,-whether they are partly caused by their imperfection, or are indicative of a specific difference. It has seemed advisable, therefore, to keep them separate for the present, as an unnamed variety of the former species.

\section{Genus-Eugaster, Hall.}

1. Eugaster? Perarmatus, Whidborne, sp. Plate XXVII, figs. $4-6 a$.

1896. Protaster perarmatus, Whidborne. Proc. Geol. Assoc., vol. xiv, p. 377.

Description.-Animal large. Upper surface of the plates of the disc and arms minutely granulated. Arms very stout, rather rapidly tapering, covered on the upper surface by a median row of broad, convex, subhexagonal plates (which seem slightly to imbricate inwardly) alternating on each side with a row of still wider subpentagonal plates, which in their turn are followed by a row of smaller plates on the perpendicular sides, bearing at their lower extremities long lateral spines at the rate of two or three to each plate. Spines thorn-like and probably about the width of the arms in length. Under side with a double row of level ambulacral plates, succeeded on each side by a row of narrow adambulacral plates, which are separated from the former by very large transverse hexagonal excavations, of which probably only the outer portions are occupied by the pores themselves. 
Size.-A small portion of an arm is $30 \mathrm{~mm}$. long; another is $10 \mathrm{~mm}$. across. Though the specimens are too fragmentary to convey much idea of the size of the animal, it is clear that it must have been considerably larger than any of the accompanying species.

Localities.-In the Museum of Practical Geology are confused masses of the arms of two animals (in three specimens) from Braunton Down. In the Porter Collection are two fragmentary portions of another animal and a third specimen from Pilton.

Remarks.-Though these specimens are too fragmentary or confused for full description, theil very large size, the stoutness of the arms, and the shape and arrangements of the plates, both above and below, show that they belong to a species quite distinct from the other star-fishes of these beds-so distinct, indeed, that it must probably be removed from the genus Protaster. The arrangement of the lower side of their rays appears, as far as can be seen, to have much in common with that of Hall's genus Eugaster, but the plates appear not to alternate but to be perfectly level.

\section{Family-Ophiuride, Agassiz, 1835.}

1. Genus-Ophiurella, Agassiz, 1835.

\section{Ophidrella ? gregaria, Whidborne, sp. Plate XXVIII, fig. 3.}

1896. Protaster gregarius, Whidborne. Proc. Geol. Assoc., vol. xiv, p. 377.

Description.-Animal small, with five very long slight arms, which taper very slowly to a very acute termination. Disc circular? with a finely granulated surface, occupied almost entirely by ten very large, curved, paired, radial plates, which form a prominent petalloid corona. Arms composed of about forty rings of squamose plates in distinctly level rows; these rows consisting on the dorsal face of a prominent, apparently indented median row, and a row on each side, the plates of which appear to have a triangular depression and to bear a series of four or five small obliquely set comb-like spines. Ambulacral plates large, level, margined by a large circular pore.

Size.-An arm (probably wanting a few terminal joints) is more than $25 \mathrm{~mm}$. long.

Locality.-In the Museum of Practical Geology is a slab, containing the remains of numerous specimens, from Braunton Down.

Remarks. - This species is distinguished from the accompanying forms by its prominent corona, the character of its plates, the absence of alternation in the 
rows of plates, and the extreme length and tenuity of its arms. From the mode of their occurrence, however, the specimens may possibly be the immature state of some other form known or unknown. It has been very difficult to distinguish between the upper and lower faces of the arms, which probably very closely resemble each other in general appearance.

Among British Palæozoic starfish this species seems most nearly to resemble Protaster leptosoma, Salter, ${ }^{1}$ both on its upper and under surfaces, but in that species the central pentagon is smaller and the shape still slighter. Comparing these two species with Furcaster palæozoicus, Stürtz, ${ }^{2}$ it seems probable that they may be members of the same group. Moreover, Mesozoic species referred by Wright ${ }^{3}$ to Ophiurella seem sufficiently similar to make it possible they may be congeneric, while a Devonian species O. primigenia is referred to Ophiurella by Stïrtz. ${ }^{4} \quad$ Again, the figures of Ophiura rhenana, Stürtz, ${ }^{5}$ show details which might correspond with the indications seen in our less well-preserved fossil. On the whole it may be well to leave it temporarily in the genus Ophiurella, to which, even if not actually belonging, it probably is nearly allied. It certainly has nothing to do with Protaster.

\section{Class-BLastoldeA, Say, 1825.}

1. Order-RÉGULARES, Etheridge and Carpenter, 1886.

\section{Family-Pentremitide, d'Orbigny, 1852.}

The species described below appears to fall within this family (as amended by Etheridge and Carpenter) from (1) possessing, as far as can be judged, minute irregularly rhombic deltoids, which occupy the extreme summits of the interradial sinuses, and (2) the spiracles being apparently situated in the oral space beyond the deltoids and not within their margins, the ambulacra being rather broad, and hydrospire-slits not being exposed outside them.

With regard to its generic position, it may be noted that its ambulacra are very long and are broader than the intervening sinuses. Its shape too, as far as can be seen, is more or less a prolate spheroid; but in none of our specimens

1 1857, Salter, 'Ann. Mag. Nat. Hist.,' ser. 2, vol. xx, p. 331, pl. ix, fig. 5.

2 1886, Stürtz, 'Palæontographica,' vol. xxxii, pl. viii, p. 79, figs. $4-5 a$; and 1890, ibid., vol. xxxvi, p. 214, pl. xxxi, figs. 40, $40 a$.

3 1866, Wright, 'Brit. Foss. Echinod. Oolitic Form.,' vol. ii, p. 154, pl. xviii, figs. $3 a$, $d$; and p. 154, woodeut 40 .

4 1886, Stürtz, 'Palæontographica,' vol. xxxii, p. 77, pl. viii, figs. 1-2a.

5 1893, Stürtz, ‘Verh. n. h. Vereins Preuss. Rheinl.,' vol. l, p. 7, pl. i, figs. 1-3. 
is the base visible, though enough of the radial plate is seen to show that the basal parts were probably at least slightly extended beyond the extremities of the arms.

It seems to differ from most species of Pentremites by the narrowness and arrangements of its arms; from most species of Pentremitidea by the length of its sinuses, and from most species of Mesoblastus by the width of its arms, the apparent shape of its spiracles, and the probable presence of an under-lancet-plate. On the whole there seems to be least difficulty in assigning it for the present to the genus Pentremitidea, but this must only be regarded as a provisional arrangement until the discovery of specimens sufficiently perfect to decide the point.

\section{Genus-Pentremitidea, d'Orbigny, 1849.}

1. Pentremitidea Philitisir, n. sp. Plate XXIX, figs. $5,5 a, 6$.

1841. Pentremites oralis, Phillips (not Goldfuss). Pal. Foss., p. 29, pl. xiv figs. $40 a, b$.

1886. Etheridge and Carpenter. Catal. Blast. Brit. Mus., p. 129.

Description.-Calix probably more or less prolately spheroidal ; summit flatly convex, broad; base unknown. Ambulacra (i.e. ambulacral areas) moderately broad, rather rapidly tapering, extending very far down the calix. Radial plates very large; bodies convex, much shorter than the limbs. Limbs very long. Interradial sinuses elongate, lanceolate, with sharp raised margins, not reaching far into the summit, and slightly narrower on the whole than the ambulacra. Deltoids indistinctly seen, very small, apparently irregularly rhombic. Spiracles apparently subcentral, undivided by septa, situate above the tops of the deltoids. Lancet-plate exposed, with a central groove and with rather distant branches, both being margined with long and coarse crenulations (which seem also to extend to the side-plates). Side-plates squarish.

Three or four hydrospire-folds seen at the distal extremity of one of the ambulacra, probably exposed by the breaking off of part of the under-lancet-plate, which appears to cover all the area between the side-plates. Radials marked with microscopic rounded lineations, slightly radiating towards the sides of the interradial sinus.

Size. - A specimen appears to be about $7 \mathrm{~mm}$. long.

Localities.-In the Barnstaple Athenæum is a specimen from Strand, Ashford, and another from Bradiford; and in my Collection is one from Wrafton Lane.

Remarks.-These specimens are all fragmentary, and consequently it is very 
difficult to make out the character of the species from them, or from the figure of Phillips's equally defective specimen, the original of which appears now to be lost. At the same time their resemblances to each other are so close that there can be no doubt that all four fossils belong to the same species.

(1) The Strand specimen is the largest. It is an inside cast. It appears to show a radial with the included ambulacrum, and (?) a deltoid (the division, however, of which from the radial is very indistinct) and the beginning of an adjoining ambulacrum. The hollows for the side-plates (and casts of the pores?) are visible.

(2) The Bradiford specimen is the cast of a single ambulacrum. It shows the median food-groove and its side-branches; the coarse crenulations upon them are very evident; the shape of the lancet-plate is perhaps discernible.

(3) The Wrafton Lane specimen is the mould of parts of the summit, of three ambulacra and of two radials. There seem to be signs of two spiracles. 'The impressions of the ambulacra seem very perfect, and show their median groove and branches, the side-plates (the marks on which are not easy to decipher), and the hydrospire pores. There are also seen two deltoids (very indistinctly) and one interradial sinus, the surface-ornament and the raised sides of which are very evident.

(4) Phillips's specimen appears to be lost. In his figure the ambulacra seem slightly broader and more triangular. The structure shown in his enlarged drawing may be either a deformity or an indication of the appearance which, in some lights, the ambulacra from our Wrafton Lane specimen assume. He describes "the general figure" as "oval, attenuated at the base," but does not show the shape of the base in his drawing.

Phillips identified his specimen with Pentremites ovalis, Goldfuss. ${ }^{1}$ The resemblance, as far as the figures can be compared, is certainly considerable. In the German figure, however, the ambulacra are broader and slightly more petaloid, the side-branches are longer, narrower, and much more numerous, the interambulacral areas are more triangular and acute, and do not extend quite so high, and the ornament of these areas, though similar, is coarser. Thus Goldfuss's fossil comes nearer to Etheridge and Carpenter's definition of the genus Pentremites as restricted by them, and though it is not absolutely proved to be different from our English species, there is the greatest probability that it is so, not only specifically but generically. Moreover it is said to have come from a Carboniferous quarry, though from beds in it which Professor Ferdinand Römer thought might possibly be Devonian. Under these circumstances it does not seem desirable to retain the German name for our Pilton fossil.

1 1826-33, Goldfuss, 'Petref. Germ.,' vol. i, p. 161, pl. 1, fig. $1 a-c$. 


\section{Family-Cononasteride, Etheridge and Carpenter, 1886.}

\section{Genus-Codonaster, $M^{\star} \mathrm{Coy}, 1849$.}

1. Codonaster conicus, n. sp. Plate XXIX, figs. 4, 4 a.

Description.-Calix very elongate, subfusiform. Base apparently trilobate. Summit very gently convex. Radial plates nearly half as long again as the basal, and separated from them by a slightly zigzag suture. Section of upper parts of the calix distinctly pentagonal, apparently becoming slightly stellate at the summit. Upper margins of the interradial sinus forming a very low triangle. (Shape of deltoid plates unobserved.) Ambulacra apparently moderately narrow, short, curving gently downwards near their distal ends. Deltoid plates apparently bearing a strong ridge along their centre. Anus semicircular, situated very near the centre? Hydrospire-slits few and coarse.

Size.-Length about $6 \mathrm{~mm}$., width about $3 \mathrm{~mm}$.

Locality.-A single specimen (with part of its mould) from Top Orchard Quarry is in the Woodwardian Museum.

Remarlss.-This little specimen is crushed, and being in the state of preservation usual in these beds its details are indistinct. This is especially the case at its summit, where not only is it squeezed together but its surface has been mostly carried away with the mould. From its general shape, however, and what indications of its structure remain, there seems no reason for doubt that it belongs to the genus Codonaster. The spaces in the ambulacra seem very few and coarse, indications of three or four of them being seen. Three or four ridges (more or less parallel) outside some of the ambulacra, where the surface is broken away, appear to be the upper part of the hydrospire-slits. Remains are seen of a circular or semicircular wall round the central area, and there is a round pit, which may be the anus. The upper margins of the interradial sinuses are defective, but they appear to have been elevated into low triangles and probably to have been bent obliquely inward at the summit. Five short coarse radii, dividing the interradial areas on the summit, appear to be the ridges on the deltoid plates.

Affinities.-From the Carboniferous C. trilobatus, $\mathrm{M}^{\circ} \mathrm{Coy}^{1}$ (which, including C. acutus, $\mathrm{M}^{\circ} \mathrm{Coy},{ }^{1}$ is the only described English species), our Pilton form is totally different in shape; but to the Upper Devonian C. Hindii, Etheridge and Carpenter, ${ }^{2}$

1 1849, M'Coy, ‘Ann. Mag. Nat. Hist.,' vol. iii, p. 251.

2 1886, Etheridge and Carpenter, 'Catal. Blastoid. Brit. Mus.' pp. passim, pl. xii, figs. 4-7. 
its likeness is very great indeed, both in general appearance and as far as can be seen in the arrangement of the ambulacra. In form, however, it distinctly differs in being still more elongate; while (though it is not possible to speak positively) it also appears more stellate in the shape of its summit and has wider ambulacra.

Its similarity to an American species of equivalent age is interesting.

5. Class-CRINOIDEA, J. S. Miller, 1821.

\section{Order-FLEXIBILTA, Zittel, $1895 .{ }^{1}$}

I. Family-Iснтнyocrinidж, Wachsmuth and Springer, 1879.

1. Genus-Taxocrinus, Phillips (apud Morris), 1843.²

1. Taxocrinus macrodactrlus, Phillips, sp. Plate XXXIII, figs. 2-4a.

1841. Cуathocrinus? (Isochinus) macrodactylus, Phillips. Pal. Foss., pp. 29, 30, pl. xv, figs. $41 a-g$. 1843. Taxocrinus macrodactiles, Morris. Catal. Brit. Foss., p. 90.

1879. - - - Wachsmuth and Springer. Proc. Acad. Nat. Sci. Philad., 1879, p. 272.

Description.-Column cylindrical, expanding considerably in the immediate proximity of the cup. Columnars rather short, alternating, becoming gradually very short as their diameter increases, having milled faces, and, as a rule, flat lateral margins, though occasionally at some distance from the cup some joints occur with convex margins. (Under basals unobserved). Basals five, very narrow, triangular. Radials five, very large, transversely quadrate. Primibrachs $5 \times 3$ (or sometimes 2 ?), similar to the radials except the uppermost, which is pentagonal and axillary. Secundibrachs $10 \times 5$, similar to the primibrachs but smaller. Succeeding series of brachials similar but progressively smaller and slightly more numerous in their rows, there being five or six series of brachials in all. Arms uniserial, sometimes curling in at their extremities. No interradials visible.

Size.-Phillips's type specimen measures $88 \mathrm{~mm}$. from the bottom of the cup to the curled extremities of the arms.

Localities.-In the Museum of Practical Geology are one of Phillips's type specimens from Pilton and five other specimens from North Devon; in my

1 Cf. 1898, F. A. Bather, 'Geol. Mag.,' Decade 4, vol. v, p. 324.

2 Cf. 1879, Wachsmuth and Springer, ‘ Proc. Acad. Nat. Sci. Philad.,' 1879, p. 270. 
Collection is a specimen of the stem, showing its expanded proximal end, from Ashhill Quarry; and in the Porter Collection are two specimens from Fremington.

Remarks.-The specimens are all obscure about the base of the dorsal cup. The shape of the basals is clearly seen from the mould, though their number is only gathered by inference.

It seems probable that Phillips's figure, $41 c$, does not belong to this species.

Affinities.—T'axocrinus nobilis, Phillips, sp., ${ }^{1}$ seems remarkably similar. Its arms appear relatively stouter, and Phillips ${ }^{2}$ distinguishes it by the fewer rows of plates in its upper series of brachials (i.e. by the more rapid branching of the arms). It also shows interradials, of which our specimens give no sign.

2. Taxocrinus stultus, Whidborne. Plate XXXIV, figs. 1-3.

1896. Taxocrinus? stulutus, Whidborne. Proc. Geol. Assoc., vol. xiv, p. 377.

Description.-Stem rather stout, cylindrical, not perceptibly expanding near the cup. Columnars with convex or bead-shaped outer margins, arranged, at some distance from the body, in an alternating series of long and medium-sized, between very short, segments, but becoming uniform and increasingly short in the proximity of the cup. Edges crenulated, especially near the cup. Under basals (apparently) three, very narrow, flatly pentagonal, visible externally. Basals five, small, transverse, and pentagonal, except the one on the anal side, which appears to be considerably larger and higher than the rest, intruding between the radials and truncated on the top, and followed by a longitudinal row of two or three small anal plates. Radials large, squarish or inversely pentagonal, in contact, except, perhaps, at their upper corners and on the anal side. Primibrachs $5 \times 3$, similar in size and shape to the radials except the uppermost plate, which is pentagonal. Secundibrachs rather smaller but similar to the primibrachs, and in rows of five or six. Upper series of brachials indistinctly seen in the specimens, but possibly short and few, and inclined to curl inwards. Under side of arms perhaps rather convex, with a very small concave groove.

Size.-A specimen of the cup and arms (their extremities perhaps unseen) is $20 \mathrm{~mm}$. high.

Localities. - In the Porter Collection is a specimen (obverse and reverse) from Pilton, and another from Poleshill. In the Barnstaple Athenæum is another from Roborough. 
Remarlis.-This little species appears to fall well within the limits of the genus Taxocrinus as restricted by Wachsmuth and Springer. It is distinguished from T. macrodactylus by various points, among others by the proximate columnars being much higher and being uniform in diameter. The arms also seem relatively much stouter.

Close examination has proved the short synopsis of the species which I originally gave to be incorrect; the plates in the best of the specimens are very difficult to distinguish, and it was only by tracing them out plate by plate that their true relationship, as seen in the opposite halves of the fossil, could be ascertained.

2. Order-CAMERATA, Wachsmuth and Springer, 1885.

I. Family-RhоDUсRInidж, F. Römer, 1855 .

1. Genus-RHodocrinus, J. S. Miller, 1821.

1. Rhodocrinus?, ? sp. Plate XXXI, figs. $3-3 d$.

Size.-A distorted cup measures $25 \mathrm{~mm}$. by $12 \mathrm{~mm}$. in transverse sections, and the accompanying arm is $60 \mathrm{~mm}$. long.

Localities.-In the Museum of Practical Geology is a specimen (with its reverse) from North Devon of a flattened dorsal cup with some expanded arms; and in the Woodwardian Museum from south-west of Sloly is the broken base of another cup, which may, from its somewhat similar ornamentation, possibly belong to the same species.

Remarlis.-Though the first of these specimens is not in a condition to permit its identification, it appears distinct from any of the accompanying Crinoids. The dorsal cup is large, and was probably deeply conical or subglobose, and composed in large part of hexagonal plates arranged something in the style of Actinocrinus; but it is now so much flattened and cloaked by matrix that few of its plates can be seen, and their exact arrangement cannot be traced. The plates that are visible seem small and numerous, and they are marked with coarse nodules having a stellate arrangement. From the margins of the cup a number of very slender and long arms take their rise. Signs of only eight or ten of these arms remain, but it appears probable that there were originally twenty, of which ten were small and did not bifurcate, and ten were larger. These larger arms have more than five rather narrow uniserial plates before their first bifurcation, after which the plates 
become cuneate, and at last definitely biserial, and the arms do not appear to branch again. The greatest portion of these longer arms is clothed by exceedingly fine and elongate, close-set, hair-like pinnules, with ten or fifteen long segments, so that they have much the appearance of a feather from a bird's tail. These arms are totally different in general aspect from those of Actinocrinus Porteri.

Mr. Bather, who has kindly examined the specimen, expresses the arm-formula thus :

$$
\overline{\mathrm{I} \mathrm{Br}} \text { - - } \overline{\mathrm{II}} \text { Br. - }<\text { thick III Br.-IV B. (F.) - pinnules. }
$$

To what genus this fossil belongs is most uncertain. There seem some slight grounds for supposing that it might belong to Rloodocrinus, and therefore with much hesitation I have placed it tentatively there.

II. Family-Batockinide, Wachsmuth and Springer, 1897.

1. Genus-Megistoorinus, Oven and Shumard, 1852.

1. Megistocininus?, sp. Plate XXXVII, fig. 5.

Remarks.-In the Woodwardian Museum, from Barnstaple, is the imperfect cast of the dorsal cup of a Camarate Crinoid which measures about $10 \mathrm{~mm}$. wide, and which appears to be distinguished from Actinocrinus Porteri by the much more uniform size of its plates.

In this specimen (taking a single ray) the lowest plate seen appears to be a radial, which, however, is almost destroyed; this is followed by a small hexagonal first primibrach, and this by a similar sized, polygonal, axillary primibrach. This, again, is followed by two pairs of hardly smaller secundibrachs, the first hexagonal, the second axillary; and between these are three or four small interaxillary plates. The interambulacral plates in the adjoining area (which may be an anal area ?) are very numerous; there seem three in the second row, and four in the third and fourth rows.

It seems, as far as can be judged, sufficiently like a Megistocrinus to be placed tentatively in that genus. 


\section{Family-MeLourinide, Zittel, 1880.}

\section{Genus-Mariocrinus, Hall, 1859.}

Tho what genus the following species belongs seems very doubtful. Being monocyclic with four basals and presumably without an anal in the radial ring, it is however, excluded from Melocrinus by its uniserial arms, and their mode of branching.

The Silurian genus Mariocrinus ${ }^{1}$ perhaps presents the least difficulty. According to Wachsmuth and Springer it differs from Melocrinus in having uniserial arm-plates. Some of its arms, however, are stated to be simple, whereas those of our fossils probably all fork once a long way up. The number of plates, moreover, which are contained in the cup in our species seems very much fewer.

1. Mariocrinus? Mundus, n. sp. Plate XXXIV, fig. 5? and Plate XXXVII, figs. 6,7 .

Description.-Stem round, very long, consisting of rather long, uniform, rather convex columnars in the lower parts, which become very short and more convex near the cup, the uppermost joint being apparently formed only halfway round. Margins of columnars very strongly crenulated. Dorsal cup elongate, vasiform. Basals four, about as long as their width. Radials five, very large, hexagonal or heptagonal, longer than wide, with flat upper margins. First primibrachs much smaller than the radials, pentagonal, axillary. Secundibrachs slightly smaller than the primibrachs, pentagonal, included within the cup, bearing two arms. Interambulacral plates (in one observed area), one resting on the shoulders of two radials, and about the same size as and at rather a lower level than the first. primibrachs, hexagonal, bearing on its shoulders two much smaller interambulacrals of the second row. Anal side unobserved. Arms twenty ? uniserial, apparently short (about one and a half times the length of calix), tapering, composed of alternating wedge-shaped plates, bifurcating at about the fifteenth joint, and without any visible signs of pinnules.

Size.-A specimen with stem and arms measures about $110 \mathrm{~mm}$., the cup being about $7 \mathrm{~mm}$., and the arms $14 \mathrm{~mm}$.

Localities.-A single specimen from Croyde Rocks is in nıy Collection; and in the Barnstaple Athenæum is a doubtful specimen from Braunton (Pl. XXXIV, fig. 5) showing a few plates of the cup and parts of the stem and arms, which possibly may belong to the same species.

1 1881, Wachsmuth and Springer, 'Proc. Acad. Nat. Sci. Philad.,' 1881, p. 288. 
Remarls. - The Croyde specimen possesses the customary indistinctness of our fossils, for though both sides of the mould and the central cast are preserved, the cup is much distorted, and each side of it is obliterated. Hence its plates cannot be perfectly traced; and, particularly, it seems a little doubtful whether the first primibrachs are axillary, so as to produce twenty arms instead of ten; $i$. e. whether the following series of plates are second primibrachs or secundibrachs. The exposed face shows five arms, but their junction with the cup is obscure.

In the Athenæum specimen the stem is slight and round, and apparently bears a few fine cirrhi, and (some distance from the cup) every eighth columnar seems enlarged. In the cup a vertical row of five or six small polygonal plates may be traced, which may be a basal, a radial, and one or two primibrachs and secundibrachs, but there are too few plates shown to make their characters clear. The arms are comparatively much larger and more massive, uniserial, formed of rather long plates, clothed with rather sparse pinnules, and bifurcating some six or eight plates up. Its identity with the former specimen is very doubtful.

\section{Family-AC'Inocrinidæ, F. Römer, 1855.}

1. Genus-Actinocrinus, J. S. Miller, 1821.

1. Aotinocrinus Ponteri, Whidborne. Plate V, fig. 21 ; Plate XXX, fig. 8; Plate XXXI, figs. $1,1 a, 2,5$; and Plate XXXII, fig. 1.

1896. Actinocrinus Porteni, Whidhorne. Proc. Geol. Assoc., vol. xiv, p. 377.

Description.-Column long, round, with short alternating or doubly alternating segments. Larger columnars with a large prominent squared central band occupying more than half of their flat peripheries, and with about thirtyfive rather stout submarginal radiations on their articulating surfaces. Central canal petaliform in section, dumb-bell-shaped between the sutures.

Calix large. Basals three (?), very narrow, hexagonal. Radials five, moderate in size, hexagonal. First primibrachs similar to the radials, but rather smaller. Second primibrachs rather smaller than the first, pentagonal. Secundibrachs $10 \times 1$, smaller than the primibrachs, pentagoual. Arms probably twenty, with short plates, uniserial for the first two or three plates (which are included in the cup), then biserial with alternating plates, branching at somewhat uneven heights from thirteen to twenty plates up, and again at still more uneven heights higher up.

Interradials (in one interradial area) - in the first row, one plate intercalated between, and of the same size as, the first primibrachs-in the second row two, smaller, and situated between the first and second primibrachs-in the third row 
three, situated on the level of the second primibrach-in the fourth row three which are very small. Anal area (Pl. V, fig. 21) with-in the first row, an aual plate equal to and intercalated between the radials-in the second row, three plates arching over the former, and more or less level with the first primibrachs (the two lateral of these being of the same size as the primibrachs, and the ceutral smaller) - in the third row four (or five?) smaller plates-in the fourth row five smaller plates rather irregularly placed, and above these several more small irregularly placed plates. (The only specimen showing the anal area is, however, too obscure to permit certainty as to the above numbers.)

Plates of the dome small and bearing central bosses, but in the condition of the specimens not individually decipherable. Arms thickly clothed with long and large, close-set tapering pinnules, having six or seven joints. Ornament of bodyplates nodular-radiate.

Size.-A specimen of a portion of a dorsal cup is about $35 \mathrm{~mm}$. across at the base of the arms.

Localities.-In the Museum of Practical Geology are two slabs containing portions of two very large specimens from Braunton, half a calix with stem from Barnstaple, another calix with arms from Barnstaple, and another specimen showing the arms and part of the dome, and another of a calix divided transversely from North Devon. In the Woodwardian Museum are two specimens of the dorsal cup, and two of the arms from Barnstaple. In the Porter Collection is a specimen of the dorsal cup, and two of portions of the arms from Pilton.

Remarks. - Although several of these fossils are much finer as specimens than are often found in the Pilton Beds, none of them show the entire cup, and therefore it is not easy to judge of the value of their individual plates without some uncertainty. The plates of the dorsal cup are ornamented by coarse radiating ridges, and the starting of the arms form clustered projections from the side of the cup, after the manner of typical forms of Actinocrinus, with which genus it appears to agree generally, unless it be in the mode of branching of its arms.

A curious case of deformity occurs in one of the specimens (Pl. XXXI, figs. $1,1 a, 2)$. One of its arms, insteal of simply bifurcating at the thirteenth joint, divides into three branches at once. These three new arms go off as nearly as possible at the same level; the regular biserial arrangement of the back of the arm is broken at the beginning of the division by several small plates, mostly pentagonal in shape, but it is at once resumed as soon as the division is completed.

Another specimen of a dorsal cup in the Porter Collection (Pl. V, fig. 21) is interesting as having had its dome covered by a Capulus (Orthonychia). 
2. Actinocrinus? Batreri, Whidborne. Plate XXXII, figs. 2-3b.

1896. Actinocirinus Bathert, Whidborne. ${ }^{1}$ Proc. Geol. Assoc., vol. xiv, p. 377.

Description.-Dorsal cup rather shallow, conical, apparently considerably wider than high. Basals three, apparently wide and very short, with convex surfaces forming a kind of rim or bead round the base. Radials and first and second primibrachs very indistinctly seen, apparently small, subhexagonal, wider than high, and regularly decreasing in size. Secundibrachs very large, pentagonal, axillary. Arms twenty, uniserial for the first seven or eight joints, and then becoming biserial, clothed with strong, close, tapering pinnules. Interambulacral plates of the first row apparently large and hexagonal, and of succeeding rows much smaller and narrower. One (or two) interaxillary plates between each pair of secundibrachs. Dome apparently not quite as high as the cup, composed of very numerous plates, each bearing a very large globular boss. Surface of dorsal cup covered with extremely strong ridges, forming a coarse stellate pattern.

Size.-Height of dorsal cup about $7 \mathrm{~mm}$., width about $13 \mathrm{~mm}$.

Locality.-A specimen of the dorsal cup and arms, on two slabs obliquely divided, is in the Museum of Practical Geology from Braunton; and a doubtful specimen of the base of a cup is in the Woodwardian Museum from south-west of Sloly.

Remarlis.-The very strong ornament, together with the poorly preserved surface of this fossil, which is in the condition of a mould, has rendered it quite impossible to trace more than a very few of the plates in the lower part of the cup. Those that can be traced appear on the whole to have the characters and arrangement of Actinocrinus, the basals being evidently very short, the radials and primibrachs probably rather wider than high. 'They all seem relatively small compared to the secundibrachs, which are large, convex, and smooth, and in this respect the fossil differs so remarkably from $A$. Porteri that there seems no doubt that it belongs to a distinct species, if not genus.

1 By thus naming this species I had meant to express my gratitude to my friend Mr. F. A. Batler for some kind help in regard to it. I was unaware at the time that he preferred that species should not bear personal names. 


\section{Family-Pla'trorinider, F. Römer, 1855.}

1. Genus-Platyorinds, J. S. Miller, 1821.

1. Platycrinus ? anguliferus, n. sp. Plate XXXVII, figs. 8-12.

Description.-Cup probably elongate. Basal disc nearly horizontal? Radials large, upright, suboblong, higher than wide, with a low excavation above, and ornamented by two or three central perpendicular ridges, from which four or five horizontal ridges start to the sides. Second primibrach axillary. Arms uniserial, with very low alternating cuneate plates (not quite reaching the sides), very long and moderately slender, sending out branches some distance up, and bearing close-set pinnules. Some small interradials on the shoulders of the radials.

Size.-Radials 8 or $10 \mathrm{~mm}$. high.

Localities.-A crushed specimen from Saunton Hotel, consisting of parts of foul' radials with arms attached, is in Mr. Coomara Swamy's Collection; three detached radials from Top Orchard, Roborough, and Pilton are in the Porter Collection; and one from Ashhill Quarry and another from Croyde are in my Collection. A detached columnar of a Platycrinus from Vicarage Lane, Pilton, in the Barnstaple Athenæum, may perhaps belong to this species.

Remarls. -These specimens appear to be the remains of a fine species, the full characters of which cannot at present be ascertained. I have long been acquainted with the scattered plates, which are very similar in shape to those of Platycrinus or Hexacrinus, and are curiously ornamented with strong ridges which do not radiate, but form a succession of right angles on their surface. Recently Mr. Swamy has lent me a specimen showing part of the cup and arms, but these are unfortunately somewhat obscured by crushing. I have not observed any anal plate among the specimens, and though it is possible that one may have existed in the cup, it seems rather more probable that it was wanting. If it is a Platycrinus it is quite possible that the highly nodulate segment of a Platycrinus stem in the Barnstaple Athenæum may have belonged to it.

VI. Family-Hexucrinide, Wachsmuth and Springer, 1885.

1. Genus-Adelocrinus, Phillips, 1841.

So little appears to be known about the single species on which Phillips founded it, that the validity of this genus must remain for the present entirely in doubt. It has of late been sometimes treated as a synonym of Platycrinus. 
The occurrence, however, of a small detached plate (Pl. XXX, fig. 2), suspiciously like the anal of Hexacrinus, makes it more likely that it was related to that genus. But its style of ornament so closely resembles that of Arthracantha as to suggest its identity with it. However, though the little tubercles which cover the body-plates are so elongate that they may be probably regarded as spines, I have been unable to trace their full length or their shape, and am not quite certain that they are moveable. Hence, while this view may ultimately be found correct, it certainly cannot as yet be asserted positively. It seems therefore best to retain for the present Phillips's existing name for whatever it may be worth, rather than to unite it with any genus from which it might again bave to be separated.

1. Adelocrinus hystrix, Phillips. Plate XXX, figs. $1-7 a$.

1841. Adelocrinus hrstrix, Phillips. Pal. Foss., p. 30, p]. xvi, fig. $42 a, b$.

Description.-Dorsal cup large, deep, apparently obconical, composed of large plates, which seem to be thin, covered with more or less numerous small elongate tubercles or spines, and so closely united that signs of the sutures are rarely discernible. Basal plates three, forming a shallow cone. Radials large, higher than wide, subpentagonal, with a small excavation above. Anal plate? narrow, subquadrate. No other plates of the calix decipherable except a few small polygonal plates (apparently of the dome), each of which bears a large rounded central tubercle. Arms stout, probably not very long, about ten in number, and not branching; biserial, composed of rather high joints, and clothed with long stout pinnules.

Size.-A specimen of the cup with closed arms (perhaps not fully shown) is about $40 \mathrm{~mm}$. long.

Localities.-In the Museum of Practical Geology are a dorsal cup (Phillips's type) from Brushford, a portion of another cup and some arms from Braunton, and two detached plates from Barnstaple. In the Barnstaple Athenæum are a cup with arms (mould and reverse) and a plate of the calix with some arms from Top Orchard, and portions of two other cups from Braunton. In the Porter Collection are portions of three cups and two detached plates from Pilton. Fragments of the dorsal cup do not appear to be rare.

Remarls.-Although several specimens have been found, we are unable to carry the description of this species very much further than where Phillips left it. Repeated examination of the specimens has only resulted in showing indistinct signs of the division of the lower part of the cup into three unequal plates; and the shape of the radials is only known from detached plates. The plates appear to 
have been very thin and very intimately united, consequently it is quite impossible to trace the divisions of the upper parts of the calix, which are, moreover, in many of the specimens wanting. Some of the arms are, however, occasionally clearly shown, and a few scattered plates of the dome are seen in one of the specimens.

The tubercles on the plates of the cup seem to vary very considerably in number and size. They appear to be conical, and higher than wide, and may be in the shape of small spines.

Affinities.-The basal disc is remarkably like that of Arthracantha Ithacensis, Williams, ${ }^{1}$ as figured by Wachsmuth and Springer ; ${ }^{2}$ but, if it had spines, they were probably very much smaller and more like those of $A$. punctobrachiata, Hall, sp. ${ }^{3}$ The ornament of Hexacrinus interscapularis, Phillips, sp., ${ }^{4}$ may also be compared.

The fossil doubtfully described by Römer ${ }^{5}$ as Ceriopora? patina certainly presents much superficial resemblance in general shape to some of our specimens, though the ornament seems closer and more regular. Römer himself notes its likeness to a Crinoid.

\section{Order-INADUNATA, Wachsmuth and Springer, 1885.}

In the maze of this order it almost requires a necromancer to bring down a species to its rightful place amid the kaleidoscopic genera that appear, change, and vanish with the progress of science. With such obscure data as our Pilton fossils the results must necessarily be highly problematical.

I. Family-Poteriocrinide, Austin, 1850? (emend. Wachsmuth and Springer, 1886).

\section{Genus-Poteriocrinus, J. S. Miller, 1821.}

Wachsmuth and Springer, ${ }^{6}$ finding difficulties in reference to Miller's type species $P$. crassus, ${ }^{7}$ propose $P$. notabilis, Meek and Worthen, as "a new, or at

1 1883, H. s. Williams, ‘ Proceed. Amer. Philos. Soc.,' p. 85, plate.

2 1897, Wachsmuth and Springer, ' N. Amer. Crinoid. Camer.,' vol. ii, p. 749, pl. lxxvi, figs. 1 a-c.

3 Ibid., p. 750, pl. lxxvi, figs. $2 a, b$.

' 1895, Whidborne, 'Dev. Fauna,' vol. ii, p. 190, pl. xxi, figs. 1-4, and pl. xxii, figs. 1-2a.

5 1850, F. A. Römer, 'Beitr. Harzgeb.,' pt. 1, p. 8, pl. ii, figs. $3 a, b$.

6 1879, Wachsmuth and Springer, ' Proc. Acad. Nat. Sci. Philad.,' 1879, p. 327.

7 1821, J. S. Miller, ' Nat. Hist. Crinoid.,' p. 68, pl. xxiii, figs. 1-17. 
least an additional type." The latter might perhaps have value as an explanatory species, but it is evident that to raise it to equal rank with P. crassus, Miller, may only make confusion worse confused. The true remedy would be a redescription of $P$. crassus from the original figured type (now in the Bristol Museum), and other carefully identified specimens of it from the same beds. As a matter of fact, it is very questionable whether Wachsmuth and Springer are even right in supposing that $P$. notabilis belongs to the same group of species. I have not been able as yet to examine closely the specimens in the Bristol Museum, but from what I am able to see of them I am inclined to think $P$. crassus may be found to have several rows of primibrachs in at least one of its arms, as stated by Austin, ${ }^{1}$ and therefore that the primibrachs are variable in the genus, as stated by Sladen, ${ }^{2}$ whereas $P$. notabilis (and therefore, according to Wachsmuth and Springer, the genus Poteriocrinus ${ }^{3}$ ) has one row only.

1. Poteriocrinus 'tensus, Whidborne. Plate XXXV, figs. 1-2; Plate XXXVIII, fig. 1.

1896. Poteriocrinus mensus, Whidborne. Proc. Geol. Assoc., vol. xiv, p. 377.

Description.-Columnars very short, with smooth peripheries. Dorsal cup high, conical. Infra-basals five, large, pentagonal, as high as wide. Basals five, hexagonal?, very high. Radials rather shorter than basals, inversely pentagonal, with excavated upper margins. First primibrachs sometimes axillary? Arms very long, uniserial, bifurcating twice, composed of truncate cuneate plates. Pinnules rather few, slight, extremely elongate, with ten or twelve distant joints. Anal plates three. Ventral sac large, cylindrical, very long, with regular longitudinal undulations, and composed of about six rows of very numerous, subquadrate, slightly transverse plates with linear slits and lateral perforations.

Size.-A cup with portions of the arms is $80 \mathrm{~mm}$. long.

Localities.-In the Woodwardian Museum is a specimen of the cup and arms, and another of a detached ventral sac from Barnstaple;-in Miss Partridge's Collection a specimen of the cup and expanded arms from Saunton Hotel; and in the Porter Collection a ventral sac from Pilton.

Remarks.-Our specimens do not show the characters very clearly; but on the whole, taking the Woodwardian specimen as the type, the species seems to

11850 ? Austin, 'Mon. Rec. Foss. Crinoid.' p. 71.

2 1877, Sladen, 'Proc. W. Rid. Yorks. Geol. Polyt. Soc.,' n. s., vol. i, p. (3).

3 1886, Wachsmuth and Springer, 'Proc. Acad. Nat. Sci. Philad.,' 1886, p. 158; but see 1897, Wachsmuth and Springer, 'N. Amer. Crinoid. Camer.,' vol. i, pp. 78, 154. 
approach $P$. crassus, and is therefore probably a typical Poteriocrinus. That specimen is accompanied by three gutta-percha casts, which appear to have brought away portions of the cup as they were taken, so as to enable the plates to be counted, though in one their interior, and in the others their exterior, casts are seen. Part of its ventral sac is exposed. Two bifurcations may be traced in the arms, but whether the plates below the first of these are primibrachs or secundibrachs is not clear; the arms seem hardly sufficiently numerous for the latter. No pinnules are visible.

In Miss Partridge's fine fossil, on the other hand, no bifurcation of the arms is observable, and this must throw some doubt on its identity with the other specimen. The arms appear ten in number (eight are seen), and they bear remarkably long and slight distant pinnules, having ten or twelve distant joints.

2. Poteriocrinus Bardmensis, Whidborne, sp. Plate XXXIV, fig. 6 ; and Plate XXXV, fig. 3 .

1896. Cyathocrinus Barumensis, Whidborne. Proc. Geol. Assoc., vol. xiv, p. 377.

Description.-Rather small. Stem cylindrical?, composed of short alternating columnars. Cup short, obconical. Infra-basals five, pentagonal, as high as wide. Basals small, hexagonal, as high as wide. Radials five, large, pentagonal, truncated above, as high as wide. Primibrachs five, large, pentagonal, as long or longer than the radials, axillary. Arms stout, very long, uniserial with truncated cuneate plates, and bearing very long close pinnules. Anal side unknown. Ventral sac large, long, composed of slightly transverse pieces with stellate marks.

Size.-A cup measures $7 \mathrm{~mm}$. wide and $6 \mathrm{~mm}$. high.

Localities.-There are two specimens (from Top Orchard Quarry and from Barnstaple) in the Woodwardian Museum. An indistinct specimen from Fremington is in the Porter Collection, and its reverse in Miss Partridge's Collection.

Remarks.-At first I supposed these fossils to be specimens of P. tensus, but further examination convinces me that they cannot be included in that species. The cup is much shorter and more globose, the basals smaller and primibrachs larger and single, and the columnars circular.

The stem in one of the specimens (Pl. XXXV, fig. 3) shows a curious deformity. Across one (and perhaps a second) longitudinal line the columnars are not continuous, but meet alternately, their line of junction being marked by a zigzag suture. 
3. Poteriocrinus, sp. Plate XXXV, figs. 4-5 a, and Plate XXXVI, figs. $9,9 a$.

Description.-Large. Stem angular near dorsal cup. Columnars short, alternating. Proximal columnar curvilinear. Dorsal cup rather high, conical. Infrabasals five, pentagonal, wider than high. Basals five. Radials rather shorter than basals, with truncated upper sides. Primibrachs $5 \times 2$ or 3 . Arms stout, uniserial, occasionally bifurcating, and composed of truncated cuneate plates, which in the lower parts (at least) bear stout short pinnules or armlets. Anal plates? Ventral sac extremely large, cylindrical, elongated, with longitudinal undulations, and composed of exceedingly short transverse pieces with long linear slits.

Size.-A dorsal cup is about $12 \mathrm{~mm}$. high. The sac of another specimen is $100 \mathrm{~mm}$. high.

Localities.-In the Museum of Practical Geology is a specimen on two slabs as well as two detached ventral sacs from Braunton Down, and another ? from Braunton; in the Woodwardian Museum is a specimen from Barnstaple; and in the Porter Collection a ventral sac from Pilton.

Remarles.-I first supposed these might be large specimens of Poteriocrinus tensus; but, though the specimens are imperfect, they reveal several points of difference, e.g. the character of the ventral sac is very different, the arm-plates seem shorter, and the arms more rapidly branching. A pinnule or armlet very near the cup (Pl. XXXV, fig. $5 a$ ) is noteworthy, as it has the appearance of bearing shorter pinnules on its side; its true character is therefore obscure.

\section{Genus-Scaphiocrinus, Hall, 1858.}

S. dichotomus is the second of the two species described by $\mathrm{Hall}^{1}$ in 1858 ; but Wachsmuth and Springer select it as the type of the genus as revised by them, because, they state, the first species belongs to the genus Graphiocrinus, de Koninck and le Hon, 1853.

1. Sodphiocrinus ? Plumifer, n. sp. Plate XXXI, figs. 4-4c ; Plate XXXIII, fig. 1 ; Plate XXXVI, figs. $1,1 a$; and Plate XXXVIII, fig. 2.

Description.-Stem becoming acutely pentagonal near the base of the cup, composed of short columnars in a doubly alternating series, having convex peri-

1 1858, Hall, ‘ Report Geol. Surv. Iowa,' vol. i, pt. 2, p. 553, woodcut 72. 
pheries. Dorsal cup basin-shaped, wider than high. Infra-basals five ? short. Basals five, almost regularly hexagonal in shape, as wide as high. Radials five, wider than high, pentagonal? convex, and with wide horizontal upper margins. Surface of plates of the cup marked with strong (sometimes intermittent) ridges, radiating from the centres of the basals and other points. Primibrachs five, in from one to six rows, the first, the second, and the sixth primibrachs appearing to be axillary in different arms. Arms elongate, branching two or three times at rather regular distances so as to become about twenty-eight in all. Brachials rugose, uniserial, cuneate, bearing numerous slight, close-set, elongate pinnules of six or eight plates. Ventral sac probably (as seen in another specimen) long and narrow, and composed of small subhexagonal pieces marked with stellate ridges. Anal apparently situated on the horizontal top of a basal, and bearing on its shoulder a second anal, above which seem to be other interambulacral plates.

Size.-A cup with the greatest portion of the arms hitherto found measures about $60 \mathrm{~mm}$. in length.

Localities. - In the Woodwardian Museum are six fine specimens of parts of the dorsal cup and arms from Barnstaple (on seven slabs); in the Barnstaple Athenæuin a specimen of the extended head, and another (on two slabs) of the closed head from Braunton; in the Museum of Practical Geology a specimen from Braunton, and in Mr. Coomara Swamy's Collection one from the Pilton Beds.

Remarks.-It appear's to me that these specimens give evidence of a wellmarked species, though in spite of the excellence of several of the specimens it seems impossible to be certain about some of its most important characters.

The elaborate ornamentation of the dorsal cup, and the ridges or rugosities on the larger arm-plates, are of some assistance in identifying the specimens ; but the plates of the cup, and especially the arrangement of the anals, are not well shown in any of the specimens, none of which enable us to trace the plates all round. One of the Woodwardian specimens shows short stout armlets of three segments upon the secundibrachs, which seem, however, only modifications of the pinnules of the higher branches.

I have found very great difficulty in locating this species in any of the genera allowed by Wachsmuth and Springer. While the ornate surface of its bodyplates would approach their definition of their restricted Poteriocrinus, the shape of the dorsal cup is quite different, as also is the arrangement of the primibrachs. While perhaps not quite falling within the limits of their emended definition of Scaphiocrinus, Hall, it certainly bears sufficient likeness to several species referred by them to that genus to be imagined congeneric. 
2. Soaphinorinus transcisus, n. sp. Plate XXXVIII, fig. 3.

Description.-Column at the base of the cup pentagonal, with very short columnars. Dorsal cup conical, rather short, apparently consisting of five rather large infra-basals, five large subbexagonal basals, five rather short radials, and three anal plates, all very strongly ornamented by large, smooth, rounded ridges, which radiate from the centres of the plates. Primibrachs $5 \times 2$ (at least in one ray), short. Arms uniserial, with cuneate plates, bifurcating again a few plates up. Ventral sac exceedingly large and heavy, composed of rather large and high pieces.

Size.-Height of dorsal cup about $25 \mathrm{~mm}$.

Localities. - A fragmentary portion of a calix and of the ventral sac from Barnstaple is in the Woodwardian Museum; and another similar specimen from Pilton is in the Porter Collection.

Remarls.-These specimens are too imperfect for anything like a full specific description. They appear most nearly to resemble S. plumifer, and I am not certain whether they may prove to be more than a variety of it. As far, however, as can be seen at present they seem to differ from it by their very much larger size, and their much less elaborate ornamentation. The ventral sac is exceedingly wide and massive. The individual plates are ornamented with five or six large bars or costæ radiating from their centres, without tubercles, in a way very like some of the plates of Poteriocrinus crassus, figured by J. S. Miller.

3. Scaphiodrinus? inordinatus, n. sp. Plate XXXIV, fig. 7 ?; Plate XXXV, fig. 6 , $6 a$; Plate XXXVIII, fig. 4.

Description.-Stem pentagonal near the cup. Columnars short, alternating, with a central raised aud perhaps nodulated band round their peripheries. Dorsal cup probably bowl-shaped and rather shallow. Infra-basals indistinctly seen, probably five, short. Basals five, small, polygonal. Radials five, large, convex, truncated above. Primibrachs large, convex, the first (at least in four of the rays) quadrate, the second pentagonal and axillary. Anal plates-one in the first row, large, elongate, apparently squeezed in between the basals, but prolonged above them, bearing in the second row a large plate resting on its upper margin, and a third above that. Surface coarsely rugose. Arms composed of elongate quadrate plates, and bearing very long pinnules.

Size.-A flattened cup is about $7 \mathrm{~mm}$. wide.

Localities.-In my Collection is a flattened specimen from Upcott Arch (on the 
two faces of a slab divided horizontally). As far as can be seen, a specimen (on the two faces of a slab divided longitudinally) from Barnstaple in the Woodwardian Museum belongs to the same species; as perhaps does also a fine but obscure specimen (divided longitudinally) from Poleshill, in the Porter Collection, and a specimen from Braunton in the Museum of Practical Geology.

Remarls. - I have drawn up the above description from the specimen from Upcott Arch. While the Woodwardian specimen from its corrugated surface and its general appearance seems probably identical, its plates are not sufficiently clear to make this certain. Its cup is of a low vasiform shape, the large radials bending outwards and being convex, so that a section across them would be petaloid. In most of the rays the second primibrach is axillary, but in one (the right anterior?) the first primibrach seems axillary, or at least it is shorter than the corresponding pairs, and no suture can be traced across it. Its arms appear to be ten in number, and clothed with strong pinnules.

To what genus this species (with the Upcott Arch specimen for its type) may belong is a perplexing question. It appears to me clear that the first anal is included in the basal ring, and is level with the basals; but, according to Wachsmuth and Springer, this arrangement exists in none of the Inadunata, though Bather ${ }^{1}$ has since proved it to occur in Thenariocrinus and one or two other genera, to neither of which, however, our species in other respects approximates. This position of the azygous plate would probably be a character of generic importance, but our specimens are not sufficiently good and indubitable to form the type of a new genus. The only course, therefore, is to leave them for the present in Scaphiocrinus, and await the evidence of further finds.

\section{Scaphiocrinus, sp. Plate XXXIV, fig. 8.}

Description. - Stem circular, with very unequal alternating columnars which have convex peripheries. Dorsal cup very shallow, bowl-shaped. Infra-basals pentagonal, very short. Basals about as high as wide. Radials large. First primibrachs very large and long, axillary. Arms large and very long, composed of rather short cuneate plates, bifurcating at about the sixth plate, and clothed with large and stout pinnules. Anal side unknown.

Size.-A cup is about $4 \mathrm{~mm}$. wide.

Localities. - In the Museum of Practical Geology is one specimen from Barnstaple and one from Braunton Down; in the Woodwardian Museum one (on two slabs) from Barnstaple; in the Porter Collection one from Poleshill; and in my Collection one from Top Orchard.

1 1890, Bather, 'Ann. Mag. Nat. Hist.,' ser. vi, vol. vi, p. 222. 
Remarles.-All these specimens are imperfect and indistinct. They seem to agree as far as can be made out, but whether they belong to a new form or to one of the accompanying species is uncertain.

\section{Scaphiocrinus? salebrosus, n. sp. Plate XXXVII, fig. 13.}

Description.-Stem pentagonal, composed near the cup of short alternate columnars with a raised central band round their peripheries. Dorsal cup rather shallow, bowl-shaped (nearly hemispherical), composed of tumid plates. Infrabasals very indistinctly seen. Basals large, convex, apparently hexagonal. Radials convex, pentagonal, truncated above, and with a linear articulating ridge. Azygous plate pentagonal, situated on the shoulders of two basals, and bearing an anal piece on its left shoulder, and another on its truncated summit. First primibrach in some of the arms axillary? Arms stout, uniserial, bifurcating (in one instance six plates up), composed of somewhat cuneate plates; (arm-furrows wide, with ligamental fossæ ?). Pinnules strong, with rather short plates. V'entral sac probably large, and covered by ridged, polygonal plates. Surface of body and arm-plates covered with a minute irregularly corrugated ornament.

Size.-A dorsal cup measures about $6 \mathrm{~mm}$. high and $9 \mathrm{~mm}$. wide.

Localities.-A specimen from Pilton is in the Porter Collection; another from Barnstaple in the Woodwardian Museum; a third from Upcott in the Barnstaple Athenæum.

Remarks.-Of these specimens the first is exposed longitudinally, the second horizontally, while the third is only a most obscure and doubtful basal part of a cup. They seem sufficient to show the distinctness of the species, but not to give a clear conception of its characters. The bowl-shaped cup with tumid plates covered with a minute ornament gives distinguishing characters. The ventral sac is not itself seen, but the occurrence of numerous peculiar plates indicates something of its size and character. It seems to differ from Poteriocrinus Barumensis by having larger basals and smaller infra-basals and by the greater tumidity of its plates.

It appears to come very near to the characters given by Wachsmuth and Springer ${ }^{1}$ for Cromyocrinus, a genus which they first unite with and then separate from Eupachycrinus, Meek and Worthen. ${ }^{2}$ It may be compared with $C$. globosus, Worthen, sp., ${ }^{3}$ and $C$. papillatus, Worthen, sp. ${ }^{4}$

1 1879, Wachsmuth and Springer, 'Proc. Nat. Sci. Philad.,' 1879, p. 356.

2 1886, ibid., 1886, p. 170.

3 1873, Meek and Worthen, 'Geol. Surv. Illin.,' vol. v, p. 557, pl. xxi, fig. 12.

4 1883, Worthen, ibid., vol. vii, p. 315, pl. xxix, fig. 17. 


\section{Genus-Scytaloorinus, Wachsmuth and Springer, 1886.}

Sladen ${ }^{1}$ founded the genus Dactylocrinus for the Poteriocrinus tenuis of Austin ${ }^{2}$ (not Miller ${ }^{3}$ ); and the species S. stadiodactylus described below, which is very similar to that species, seems quite agreeable to his definition. Wachsmuth and Springer, however, stating that his name had been preoccupied by Quenstedt in 1876 for another form, merge Sladen's genus into their own Scytalocrinus, ${ }^{4}$ to which they refer a large number of American fossils. How far our species is congeneric with some or all of these may be doubtful, though in many points it corresponds. It differs from most if not all of them in the very great length and quadrate shape of its arm-joints, and this feature was made by Sladen one of the important characters of his genus. Wachsmuth and Springer explain this away by saying that it simply betokened a young animal. In our case, however, their remark hardly appears applicable; several of our specimens show the arms, and these are of very great length, and seem to be of sufficiently mature character.

1. Scytalocrinds stadiodactylus, Whidborne, sp. Plate XXXVI, figs. 2-6, 8, and Plate XXXVII, fig. 14.

1886. Poteriocrinus stadiodactylus, Whidborne. Proc. Geol. Assoc., vol. xiv, p. 377.

1886.

Batherr, ibid., p. 377.

Description.-Stem apparently long and slender, composed of moderately high, equal or nearly equal columnars. Dorsal cup conical or slightly obconical, moderately deep. Infra-basals five, small, slightly higher than wide, pentagonal. Basals five, apparently large, higher than wide, hexagonal. Radials five ? moderately short, truncate above. Primibrachs $5 \times 2$. Arms ten, very long and slender, composed of very long, narrow, subquadrate plates, and sending out occasionally long slight armlets or pinnules. Anal side with a pentagonal azygous plate, resting on the shoulders of two basals, and bearing an anal piece on its left shoulder level with the radials, and another hexagonal anal on its summit; the last two supporting further similar plates, which appear to clothe the lower parts

1 1877, Sladen, 'Proc. W. Rid. Yorks. Geol, and Polyt. Soc.,' n. s., vol. i, p. (4), pl. x, fig. 2.

21850 ? Austin, 'Monog. Rec. and Foss. Crinoid.' p. 83, pl. x, figs. $5 a, b$.

3 1821, J. S. Miller, 'Nat. Hist. Crinoid.,' p. 71, pl. xxii, fig. 2, and pl. xxiv, figs. 1-25.

4 1879, Wachsmuth and Springer, 'Proc. Acad. Nat. Sci. Philad.,' 1879, p. 339; and 1886, ibid., 1886, pp. 157, 161. 
of the greatly elongated ventral sac, which in its higher parts is covered by slightly transverse quadrate plates, and sivells out into a slightly clavate form.

Size.-A calix is $3 \mathrm{~mm}$. high; another $6 \mathrm{~mm}$. high. The arm of a similarly sized specimen appears to be more than $50 \mathrm{~mm}$. long.

Localities.-In the Barnstaple Athenæum are one specimen from Braunton and two from Roborough; in the Woodwardian Museum are five (on four slabs) from Barnstaple; and in the Porter Collection two from Pilton.

Remarles.-The great slightness and elongation of its arm-plates and the length and mode of branching of the arms easily distinguish this form from the accompanying Crinoids. The arms do not appear to exceed ten, and are composed of alternately long and shorter quadrate plates, only the longer of which appear to bear long and relatively strong pinnules, which, therefore, do not produce the usual plumose aspect. The arms do not seem straight, but slightly waved or zigzagged, the pinnules starting from the outer angles thus formed. Possibly the pinnules themselves sometimes have a slightly waving shape, and hence they may be of rather doubtful nature, and possibly have to be reckoned as armlets, but I have not been able to recognise any branching in them.

The anal side of the cup is seen in a small specimen (Pl. XXXVI, figs. 2, $2 a$, which I should regard as the type) which retains the arms; but there it is rather distorted by accident. This specimen also shows the ventral sac, which is seen to rise from the anal plates of the cup for some distance as a narrow tube covered with elongate hexagonal plates, and then to swell out into an elongate inflated shape, when it is covered by short quadrate pieces in probably ten or twelve rows. How high it extends cannot be seen. The height of the cup being about $4 \mathrm{~mm}$, the neck of the sac is $10 \mathrm{~mm}$. long, and the inflated part more than $10 \mathrm{~mm}$.; while the width of the neck is $1 \mathrm{~mm}$., and of the inflated part $3 \mathrm{~mm}$.

The arm-plates are sometimes three times as long as their width.

Two specimens (Pl. XXXVI, figs. 6, 8) were regarded by me in 1896 as a distinct species, which I named Poteriocrinus Batheri. They seemed to differ from the type by the greater size and length of their basals, shorter columnars, and some other points. Further examination makes me very doubtful whether any of the supposed distinctions hold good, or may not have been really caused by the imperfect preservation of our specimens-the appearance of the column especially being due to decay, and the portion of an arm (fig. 7) on the same slab as fig. 6 evidently belonging to another animal of a different species. They must therefore, I think, be united with the present species.

Affinities.-Sc. loreus, Sladen, sp. ${ }^{1}$ (= Poteriocrinus tenuis, Austin), is very similar, and seems evidently congeneric, but its dorsal cup is more elongate and

1 1877, Sladen, 'Proc. W. Rid. Yorks. Geol. and Polyt. Soc.,' n. s., vol. i, p. (5), pl. x, fig. 2. 
conical, its arm-plates seem all equal, and it appears to differ in having only one row of primibrachs.

Sc. Vanhornei, Worthen, ${ }^{1}$ is also very like, both as to its dorsal cup and its ventral sac, but its arm-plates are much shorter and more cuneate. Its second primibrach is axillary.

2. Soytalocrinus arachnoideus, n. sp. Plate XXXVIII, figs. 5, 6.

Description.-Stem round, with alternate very long and moderate columnars (near the cup), which have gently convex peripheries. Dorsal cup small, apparently semi-globose (bowl-shaped). Infra-basals elongate, pentagonal? longer than wide. Basals subhexagonal, equal to the infra-basals in height but broader. Radials pentagonal, about the same size as basals, convex laterally, and with horizontal upper margins. First primibrachs large, square; second primibrachs pentagonal, axillary. Arms very long, simple, not perceptibly tapering, composed of equal plates, which are rather higher than wide, have almost horizontal sutures, and bear very long pinnules with numerous joints. Azygous plate very similar to the radials, bearing apparently another very small anal on its left shoulder, and a third on its truncated upper margin; these being followed by numerous rows of subhexagonal pieces forming a long narrow neck to the sac, which is longer than the height of the cup, the sac then expanding and forming a long reticulate bag four or five times the height of the cup.

Size.-Height of a cup $5 \mathrm{~mm}$., length of ventral sac about $40 \mathrm{~mm}$.

Localities.- There are three specimens from Barnstaple in the Woodwardian Museum.

Remarlis.-These specimens appear to have very much the same characters as Sc. stadiodactylus, but to differ distinctly from it in the structure of their arms, which are much stouter, and composed of comparatively short equal joints. The ventral sac seems also very similar. The defective state of our specimens leaves of course many of the characters indistinct and doubtful, but as their size does not seem to exceed that of the former species, they could hardly be supposed to be its adult condition, and must therefore, I think, be regarded as a new form.

1 1875, Worthen, 'Geol. Surv. Illin.,' vol. vi, p. 517, pl. xxxi, figs. 2, 3. 


\section{Genus-Cøuiocrinus, White, 1863.}

\section{Cæliocrinus, n. sp. Plate XXXVIII, fig. 7.}

Description.-Dorsal cup unseen. Arms stout, slowly diminishing in size, bifurcating at nearly level distances, the ramifications occurring only on the two outer arms of the rays, and the branches being given off toward the inner side of the ray, and remaining single throughout. Arm-plates extremely short, uniserial, cuneate. Pinnules large and long. About five plates between the first divarication seen and the second; about seven between the second and third; and about eleven between the third and fourth. Anal sac long.

Size.-A specimen with parts of the arms is $22 \mathrm{~mm}$. long.

Localities.-A single defective specimen from Barnstaple is in the Woodwardian Museum.

Remarls. - This specimen being a mass of arms with only indistinct indications of the dorsal cup is insufficient for full determination, but at the same time is distinctly different from any other Pilton Crinoid.

As far as can be seen, it has great resemblance to such forms as Zeacrinus cariniferus, Worthen, ${ }^{1}$ and Z. lyra, Meek and Worthen, ${ }^{2}$ which Wachsmuth and Springer refer to Cocliocrinus, ${ }^{3}$ a genus with a "balloon-shaped" dorsal sac, and for one of the species of which they somewhat rapaciously claim ${ }^{4}$ the well-known Echinosphærites tesselatus, Phillips, sp., ${ }^{5}$ regardless of its structure! A small portion of the ventral sac, seen in our specimen, proves it to have been large and possibly wide, but its shape is unknown, so that it is not certain whether our species belongs to this or some kindred genus. The cuneate plates of the arms, however, appear, according to Wachsmuth and Springer, to separate it from Zeacrinus, and from such species as Zeacrinus ramosus, Hall, ${ }^{6}$ or Scaphiocrinus sibæqualis, Wachsmuth and Springer, ${ }^{7}$ which, after having placed in a new genus Pachylocrinus, they afterwards referred to Woodocrinus, de Koninck, ${ }^{8}$ from the type form of which, W. macrodactylus, these species certainly have a very different aspect, though they may be more like $W$. expansus, de Koninck. ${ }^{9}$

1 1873, Meek and Worthen, ' Geol. Surv. Illin.,' vol. v, p. 535, pl. xx, fig. 4.

2 Ibid., p. 432, pl. i, fig. 11.

3 1879, Wachsmuth and Springer, 'Proc. Acad. Nat. Sci. Philad.,' 1879, p. 354.

4 1886, ibid., p. 168.

5 1841, Phillips, 'Pal. Foss.,' p. 135, pl. lix, figs. $49^{\mathrm{xx}} a, b$.

6 1858, Hall, 'Report Geol. Surv. Iowa,' vol. i, pt. 2, p. 548, pl. ix, fig. 3.

7 1873, Meek and Worthen, 'Geol. Surv. Illin.,' vol. v, p. 494, pl. xv, fig. 6 (this figure, howerer, has cuneate plates); and 1879, Wachsmuth and Springer, 'Proc. Acad. Nat. Sci. Philad.,' 1879, p. 339.

8 1854, de Koninck et le Hon, 'Recherches Crinoid. Terr. Carb. Belg.,' p. 212, pl. viii, figs. 1 a-e. 9 1858, de Koninck, 'The Geologist,' vol. i, p. 13, pl. ii, fig. 1. 


\section{PLATE XXII.}

Fig.

\section{Productus internuptus, Sowerby (?). (Page 172.)}

1. Ventral valve, lying obliquely in the matrix, showing the ribs and the interrupting grooves and ridges in the posterior parts, $\times 3$. Pilton. Porter Collection.

2. Dorsal? valve, somewhat worn, showing the transverse ridges over the whole surface, $\times 2$. Fremington. Porter Collection.

3. Portion of a crushed specimen, showing ornament, $\times$ 8. Pilton. Porter Collection.

\section{Chonetes Hardrensis, Phillips, sp. (Page 177.)}

4. Cast of dorsal valve, showing the areas of the dorsal and ventral valves, and the divaricating ribs, $\times$ 3. Saunton Hotel. My Collection.

\section{Chonetes margaritacea, Whidborne. (Page 179.)}

5. Ventral valve, showing the shape and the simple ribs, $\times 3$. $5 a$. Portion of surface, showing the shape of the ribs and the transverse ornament, $\times 10$. Roborough. Porter Collection.

6. Another specimen, much crushed, showing two of the hinge-spines, $\times 3$. Braunton. Museum of Practical Geology.

\section{Chonftes Illinoisensis, Worthen(?). (Page 179.)}

7. Dorsal valve, showing the crowded divaricating and slightly waved striæ and the slight geniculation, $\times 3$. Fremington (?). Porter Collection.

8. Ventral valve, much crushed, showing one of the long oblique hinge-spines, $\times 3$. Fremington (?). Porter Collection.

\section{Craniella insecura, n. sp. (Page 180.)}

9. Cast of dorsal valve, showing the apex, the casts of the muscle-scars, and the ornament assumed from the organism to which the other valve was attached, $x 2$. Pilton Beds. Barnstaple Athenæum.

\section{Crania? Ricta, n. sp. (Page 182.)}

10. Ventral valve, showing the divaricator, the occlusor, and the ventral adjuster (?) muscle-scars, $\times 3$. $10 a$. Portion, showing the minutely tuberculated inner surface, $\times 10$. Pilton. Porter Collection.

\section{Discina Nitida, Phillips, sp. (Page 183.)}

11. Upper valve, which is a cast in the central part, but retains the surface near the margins, the front part of which is covered by matrix, $\times \frac{3}{2}$. $11 a$. Lateral view, $\times \frac{3}{2}$. Saunton Hotel. Miss Partridge's Collection.

12. Lower valve, $\times \frac{3}{2}$. West Angle Bay, Pembrokeshire. Museum of Practical Geology.

Lingula squamiformis, Phillips. (Page 183.)

13. Dorsal valve, showing the radiations on the surface, $\times 2$. Saunton Hotel. Miss Partridge's Collection.

\section{Fenestella plebeia, $M{ }^{\prime}$ Coy. (Page 185.)}

14. Part of a large frond. 14a. A fenestrule, showing the non-poriferous surface, $\times 20.14 b$. A fenestrule, which is a natural section, showing five or six cells between the dissepiments, $\times 20$. Snapper Quarry. Hamling Collection.

15. Fragment of a frond. $15 \mathrm{a}$. Portion, showing a nodulated surface, and the section of some cells, $\times 20$. Ironpost. My Collection.

\section{Fenestelia? umbrosa, n. sp. (Page 186.)}

16. Wax impression of the natural cast of a frond. $16 \alpha$. A portion of the surface showing the blunt central keel, the shape of the fenestrules, and three or four cell-mouths to a fenestrule, $\times 20$. Roborough. Barnstaple Athenæum. 



\section{PLATE XXIII.}

Fig.

Fenestella plebeia, $\boldsymbol{M}^{\circ}$ Coy. (Page 185.).

1. Fragmentary specimen. 1 a. Portion, showing the striated non-poriferous side, and the section with four or six cells to a fenestrule (slightly restored), $\times 20$. Pilton Beds. Porter Collection.

Fenestella? umbrosa, n. sp. (Page 186.)

2. Fragmentary specimen in the condition of a cast, probably belonging to this species, but with very small fenestrules. $2 a$. Portion, showing two cells to a fenestrule, $\times 20$. Roborough. Porter Collection.

3. Fragmentary specimen of the radical portion of a frond. $3 a$. Portion, showing the keeled and striated non-poriferous side, which sometimes appears to have two cells to a fenestrule, $\times 20$. Poleshill. Porter Collection.

\section{Fenestella polyorata, Phillips. (Page 188.)}

4. Fragmentary specimen of the poriferous face. 4a. Portion, showing six cells to a fenestrule, the median keel, and the elevated cell-months, $\times 20$. Pilton Beds. Hamling Collection.

5. Fragmentary specimen of the radical portion of a frond. 5 a. Portion, showing the mode of branching, the cells, the cell-mouths, and the median keel, $\times 20$. Pilton. Porter Collection.

\section{Phinnimetipona bipinnata, Phillips, sp. (Page 190.)}

6. Portion of a large cast, showing mouths of cells. $6 a$. Portion, showing two cells on the central stem between each two of the branches, $\times 20$. Poleshill. Porter Collection.

7. Slab with several specimens retaining surface. $7 a$. Portion of a frond, showing the central keels and the cell-mouths, $\times 20$. Barustaple. Woodwardian Museum.

8. Specimen, showing the mode of branching. Pilton. Porter Collection.

\section{Penniletipolia virgata, n. sp. (Page 191.)}

9. Fragmentary specimen. 9 a. Portion, showing the numerous cells between the subsidiary branches, $\times 20$. Croyde Bay. My Collection.

\section{Streblotrypa Gregorit, Whidborne. (Page 192.)}

10. Portion of a zoarium. $10 a$. Portion of surface, showing the acute undulating ridges, the mouths of the zoccia and the mesopores, $\times 20$. Pilton Beds. Hamling Collection.

Rhabdomeson? gracile, Phillips, sp. (Page 194.)

11. Portion of a zoarium. 11 a. Portion of surface, showing cell-mouths, $\times 20$. Barnstaple. Woodwardian Museum (on a slab from which Sowerby's figure in 'Geol. Trans., ser. 2, vol. v, pt. 3, pl. liii, fig. 17, was taken).

12. Portion of a zoarium. 12 a. Portion of surface, showing cell-mouths and acanthopores, $\times 20$. Ironpost. My Collection.

13. Portion of the zoarium of a variety with larger cell-mouths. $13 a$. Portion of surface, showing the long, oval cell-mouths and pores, $\times 20$. East Anstey. My Collection.

14. Cast of a zoarium, probably belonging to this species. 14a. Purtion, showing the form of the cells, $\times 20$. Pilton. Porter Collection.

15. Portion of the natural section of a zoarium, probably belouging to this species. $15 a$. Portion, showing the shape of the cells and the central axis, $\times 20$. Pilton. Porter-Collection.

\section{Leioclema? distans, Whidborne, sp. (Page 196.)}

16. Portion of a zoarium. $16 \mathrm{a}$. Portion, showing the small, distant, oval coll-mouths and the scattered mesopores, $\times 20$. Laticosta Cave, Baggy. Hamling Collection.

Fistulipolia? sp. (Page 197.)

17. Specimen of a free zoarium. $17 a$. Portion, showing the cells, $\times 15$. Pilton. Porter Collection.

Fistultpora (?), sp. (Page 198.)

18. Specimen encrusting a coral, $\times 2$. Frankmarsh. Barnstaple A thenæum. 19. Wax cast of the portion of another specimen, encrusting a crinoid stem, $\times 20$. Barnstaple.
Woodwardian Museum. 
PLAIE XXNI.

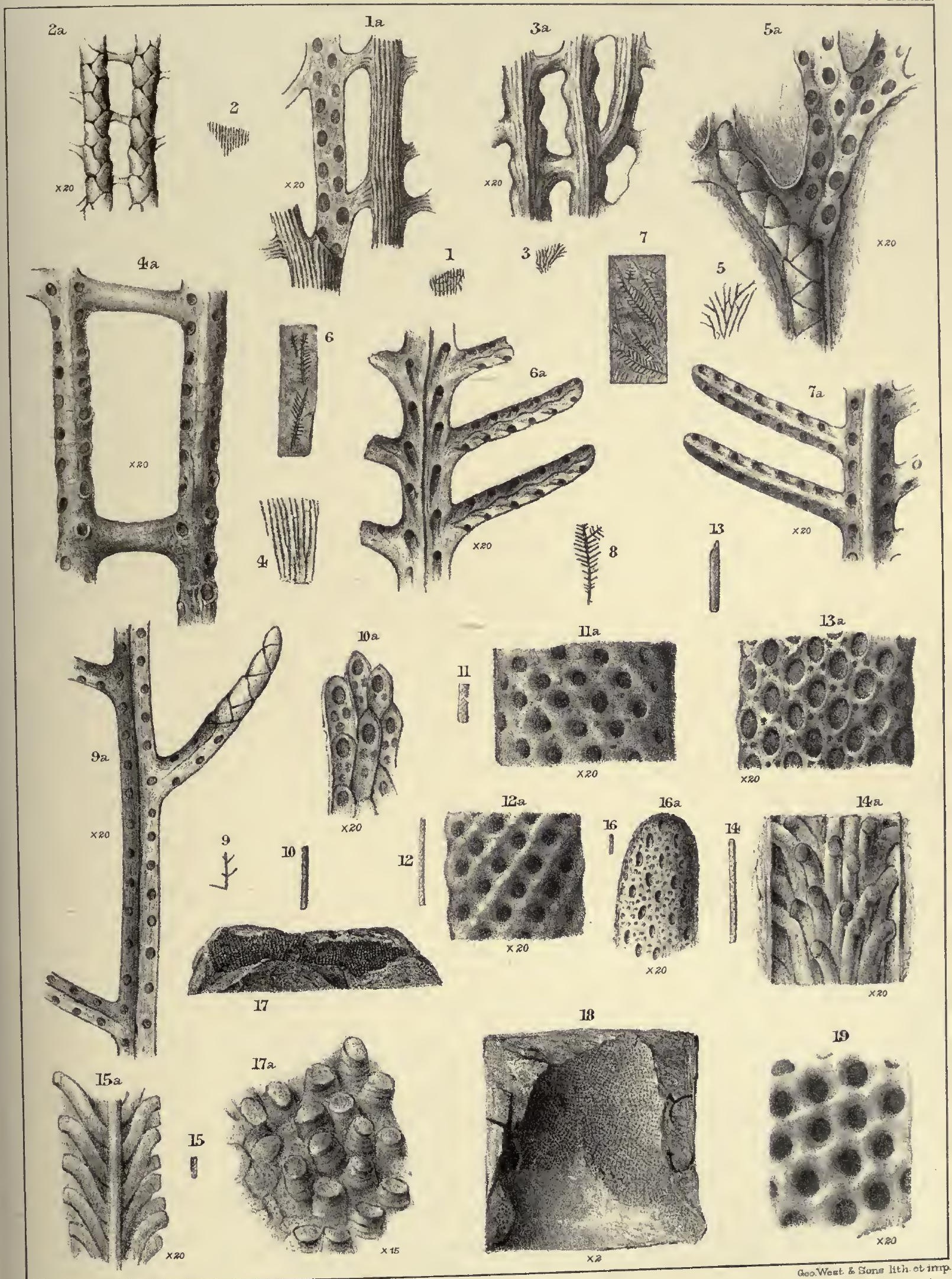




\section{PLATE XXIV.}

Lepidesthes? devonioans, Whidborne. (Page 200.)

FIG.

1. One side of the mould of a nearly perfect but flattened and compressed specimen, in which the remains of the lantern are seen, and the ten areas may be roughly traced, nat. size. Pilton Beds, North Devon. Museum of Practical Geology.

2. Portion of the opposite face of the same specimen, showing numerous spines and interambulacral and ambulacral plates, $\times 2$. Pilton Beds, North Devon. Museum of Practical Geology. 

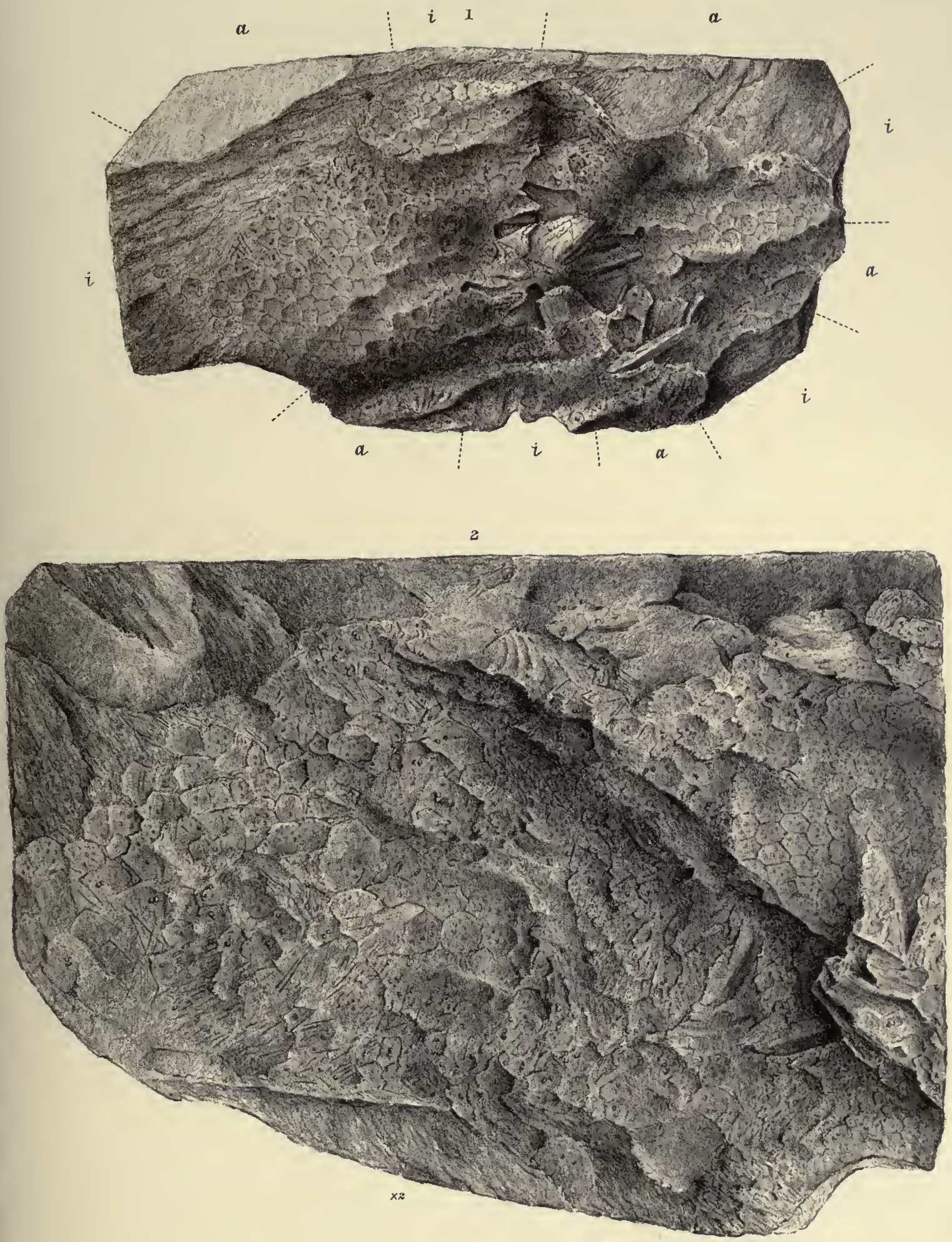

Goo.Wout. so Sons Jith. et imp 



\section{PLATE XXV.}

\section{Pliotocidaris acuaria, n. sp. (Page 203.)}

FIG.

1. Mould of a portion of a crushed test, showing numerous interambulacral plates and spines, $\times 2 . \quad 1 a$. Portion of the same, showing a tubercle and parts of two spines, $\times 25.1 \mathrm{~b}$. Portion of the same, showing several plates and large and small spines, $\times 5$. East of Barnstaple. Museum of Practical Geology.

2. Another specimen, probably belonging to the same test, showing remains of the lantern-apparatus, nat. size. $2 a$. Portion of one of the bones of the lantern, $\times 10$. East of Barnstaple. Museum of Practical Geology.

\section{Lepides'thes? Devonicans, Whidborne. (Page 200.)}

$3 a$. Wax cast of some interambulacral plates from the test figured on Pl. XXIV, showing their shape and ornamentation, $\times 5.36$. Wax cast of some ambulacral plates, $\times 5.3 \mathrm{c}$. Portion of an interambulacral plate, showing a tubercle, $\times 25.3 d$. Portion of a spine, $\times 25$. $3 e$. Another spine, $\times 10.3 f$. An ambulacral plate, showing its thickness, $\times 10$. Pilton Beds, North Devon. Museum of Practical Geology. 
rif (n)

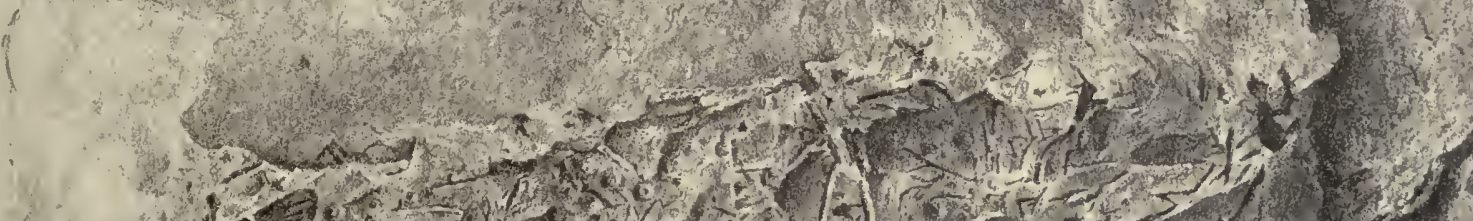

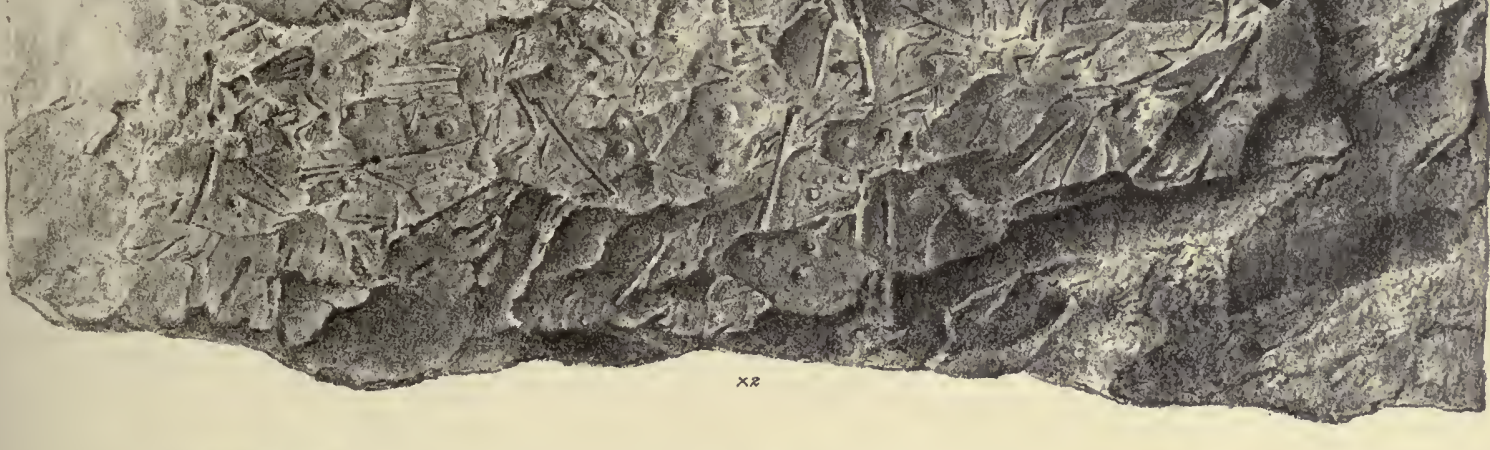
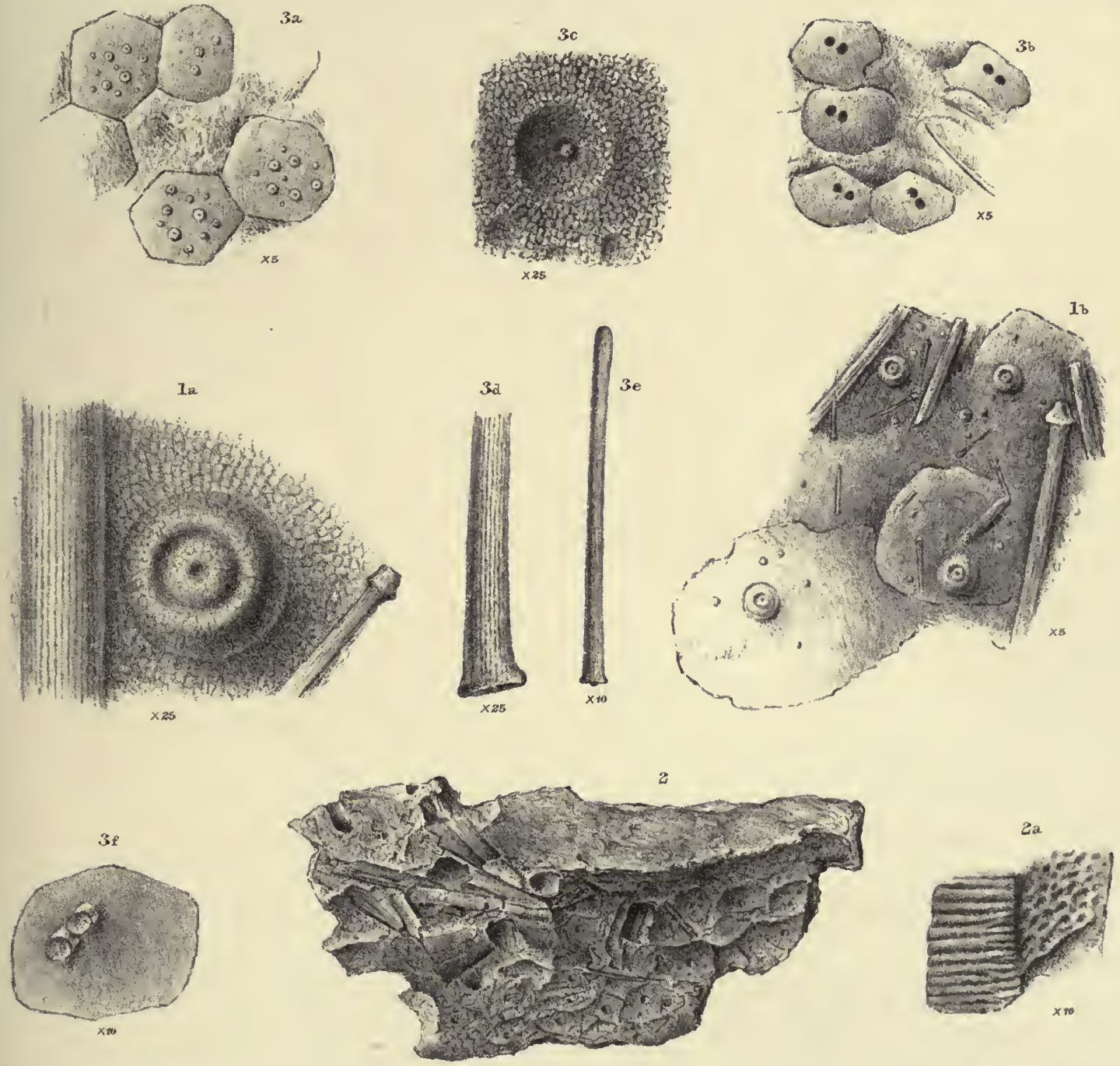

Geo. Wert \& Sone lith et 1mp. 



\section{PLA'IE XXVI.}

\section{Paleaster longimanus, Whidborne. (Page 204.)}

Fig.

1. Mould of the upper surface of a specimen, $\times 3.1$ a. Wax impression of a portion of the same, showing the arrangement of the plates, $\times 5$. Park, near Braunton. Museum of Practical Geology.

2. Mould of the under surface of the same animal, $\times 3$. Park, near Braunton. Museum of Practical Geology.

3. Mould of the under surface of another specimen, showing the length of the arms, $\times 3$. $3 a$. Wax impression, showing the mouth, $\times 5$. $3 b$. Wax impression of an arm, which has been tristed so as to show its upper side, $\times$ 8. Baggy Point. Museum of Practical Geology.

4. Wax impression from another specimen, showing the mouth and parts of the arms, $\times 6$. Pilton. Porter Collection.

\section{Protaster granifer, Whidborne, sp. (Page 207)}

5. Mould of the lower surface, $\times \frac{3}{2}$. $5 a$. Wax impression from a portion of one of the arms showing (indistinctly) the arrangement of the plates, $\times 3$. Pilton Beds, North Devon. Museum of Practical Geology.

6. Mould of the upper surface of the same animal, $\times \frac{3}{2}$. $6 a$. Wax impression of a portion of the surface, $\times 15$. Pilton Beds, North Devon. Museum of Practical Geology. 

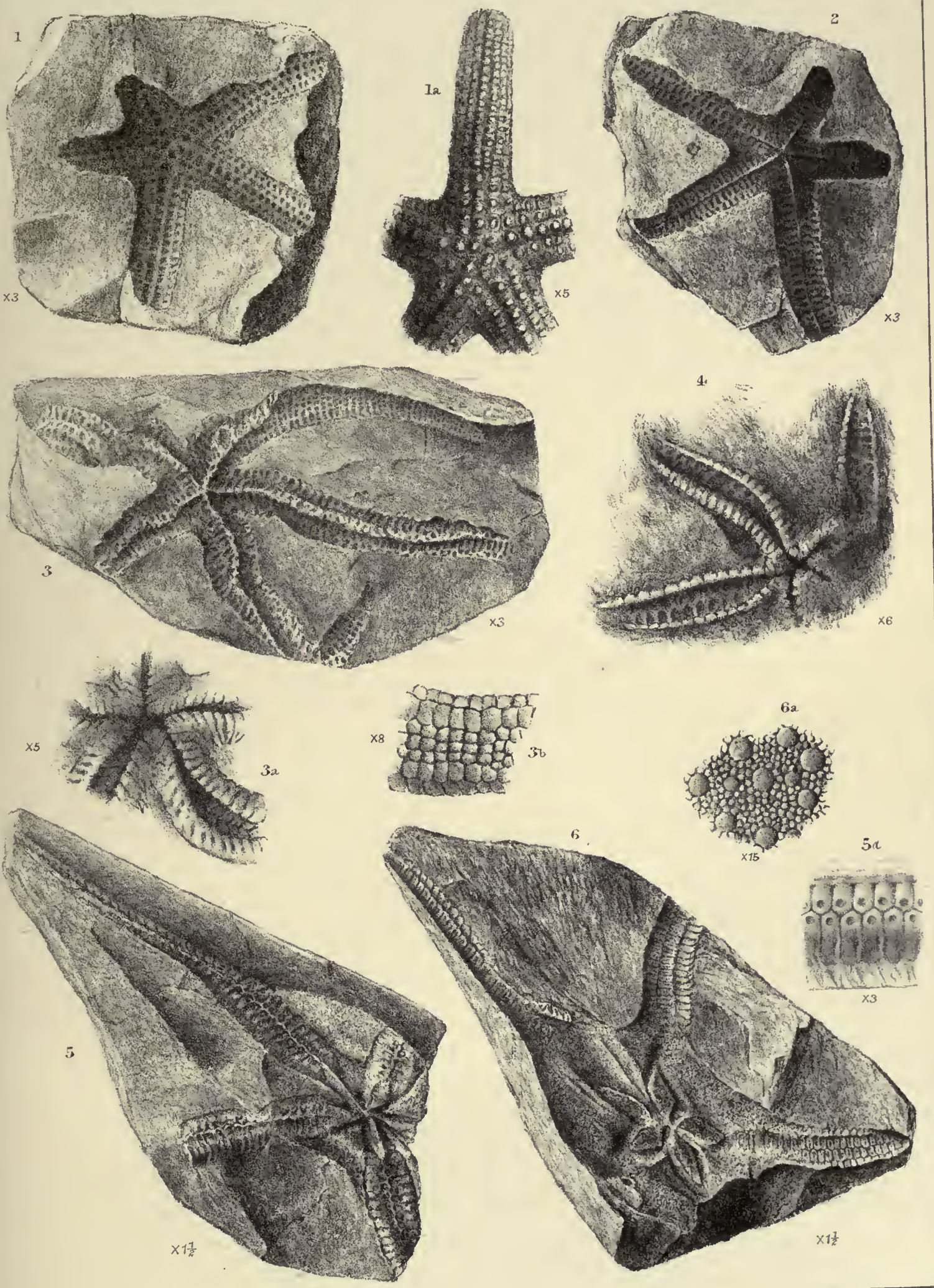

Geo Weat \& Sone lith.et :m 


\section{PLATE XXVII.}

Protaster? (Drepanaster) scabrosus, Whidborne, var. (Page 208.)

FIG.

1. Under surface of an indistinct specimen, $\times 2 . \quad 1 a$. Wax impression of a portion of one of the arms, $\times 4$. Top Orchard Quarry. Hamling Collection.

2. Upper surface of the same animal, $\times 2.2 a$. Wax impression of a portion of one of the arms, $\times 4.2 b$, Side view of the same, $\times 2.2 c$. Wax impression of a portion of the surface, $\times 10$. Top Orchard Quarry, Hamling Collection.

3. Another specimen in a very poor state of preservation, $\times 3$. Fremington. Porter Collection.

\section{EUgaster? perarmatus, Whidborne, sp. (Page 209.)}

4. Wax impression from the mould of the lower side of an arm, $\times \frac{7}{2}$. Poleshill. Porter Collection.

5. Wax impression from the mould of portions of the upper sides of three arms, $\times 2$. Poleshill. Porter Collection.

6. A confused group of arms from another animal. $6 a$. Wax impression of one of the arms, $\times 4$. Braunton Down. Museum of Practical Geology. 






\section{PLATE XXVIII.}

Protaster? (Drepanaster) soabrosus, Whidborne, var. (Page 208.)

FIG.

1. Under side of a specimen, $\times 3.1 a$. Wax impression, shorving the oral arrangement, $\times 5.1 \mathrm{~b}$. Wax impression of a portion of the arms, $\times 7$. Croyde. Museum of Practical Geology.

2. Under side of another specimen, $\times 3.2 a$. Wax impression of a portion of one of the arms, $\times 10.2 \mathrm{~b}$. A small portion of the surface of the same, $\times 70$. Croyde. Museum of Practical Geology.

\section{Ophiurella? Gregaria, Whidborne, sp. (Page 210.)}

3. Wax impression of a portion of the mould of a specimen, $\times 5$. (The longest portion of arm here shown is only three fifths of its full length.) Braunton Down. Museum of Practical Geology. 
PIATE XXVIL
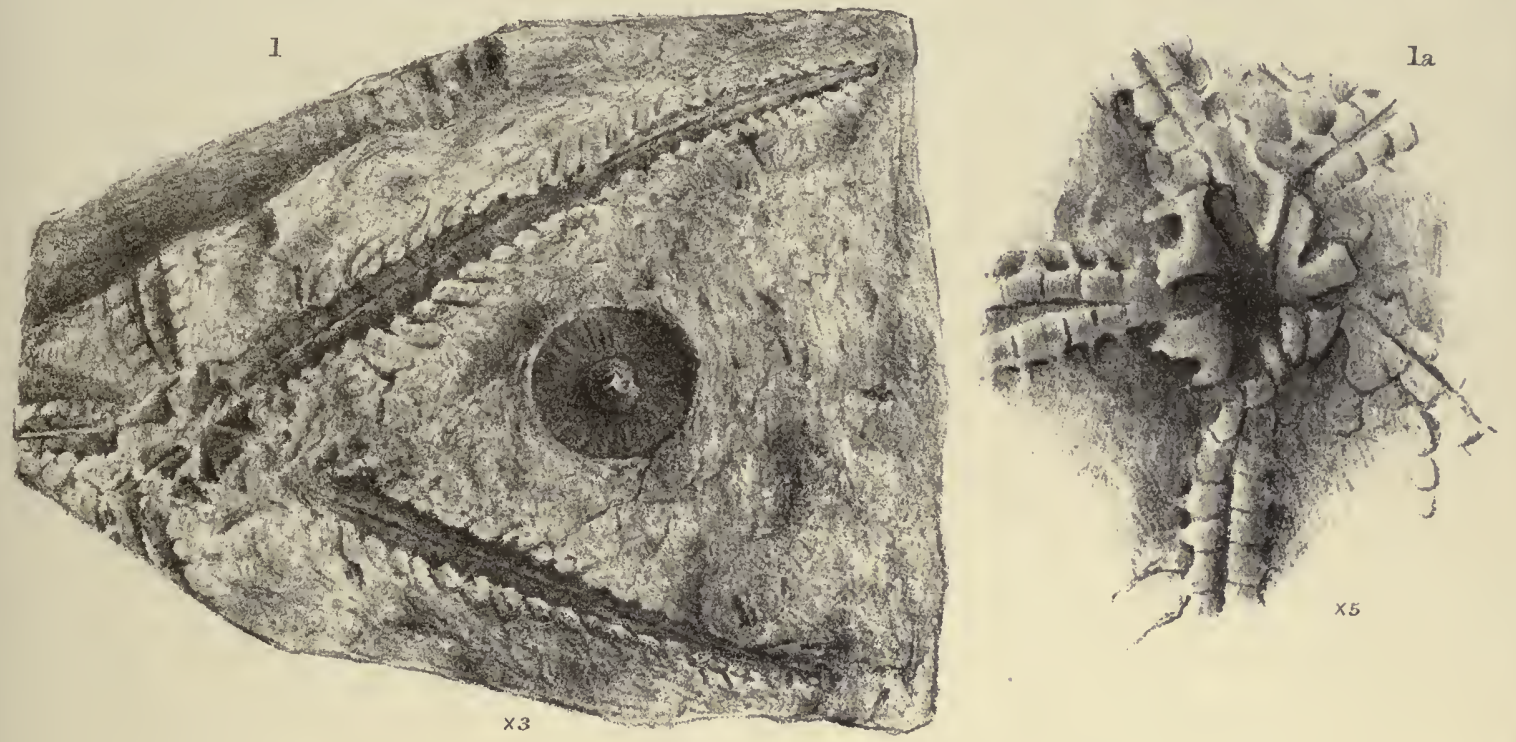

16
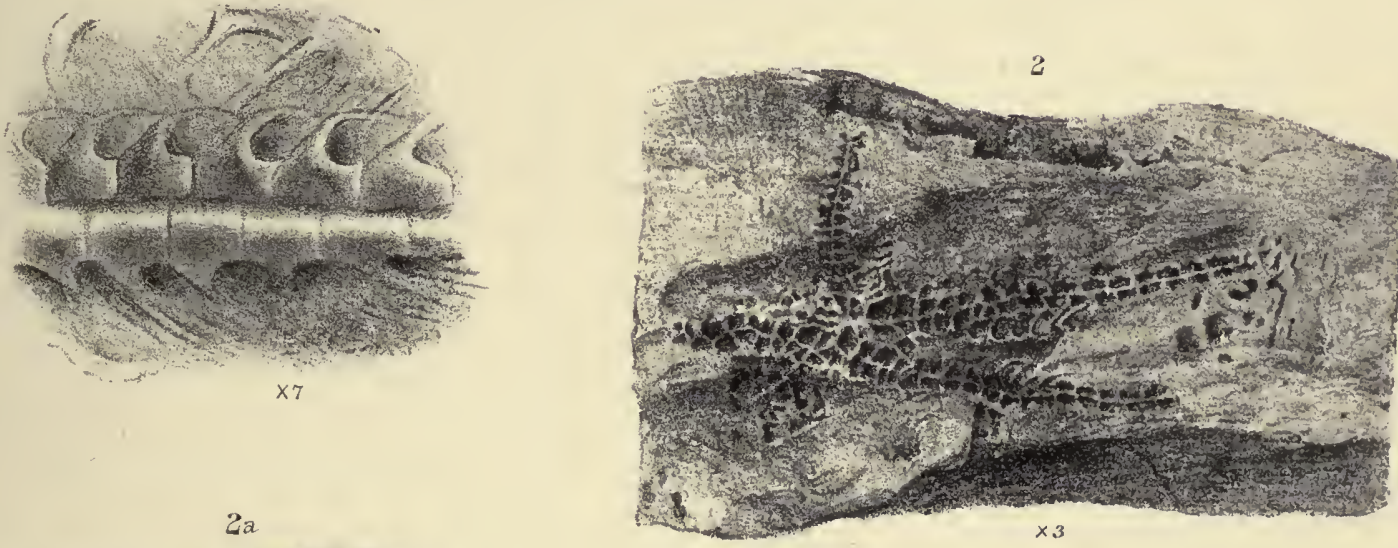

$2 a$

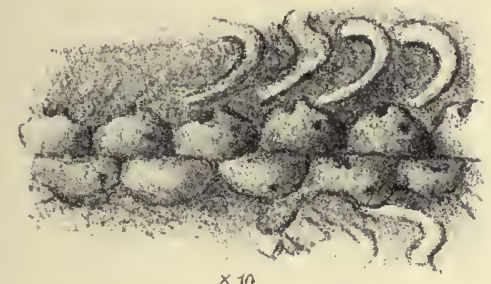

36

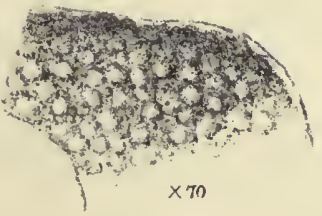

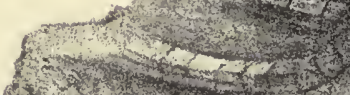

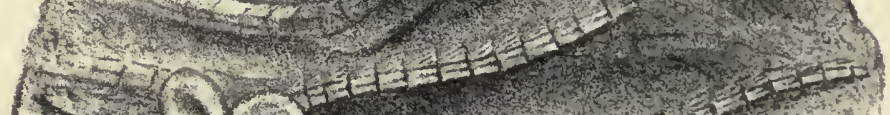

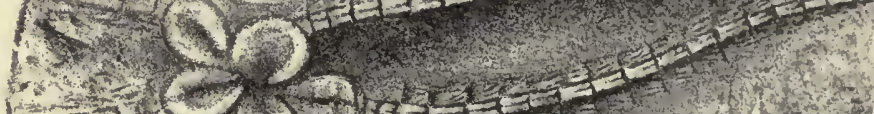

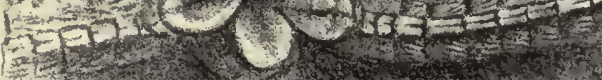

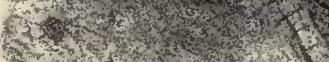


-

$-$ 



\section{PLATE XXIX.}

FIG.

Protaster? (Drepanaster) scabrosus, Whidborne. (Page 208.)

1. Specimen showing the small plates of the dorsal surface of the disc and portions of the arms, and the lateral spines, $\times 5.1 a, 1 b$. Wax impressions of two portions of the arms, $\times 10$. Croyde Bay. Barnstaple Athenæum.

2. Another specimen, showing the lower side of an animal, $\times 3.2 a$. Wax impression of a portion of one of the arms, $\times 10$. Braunton Dorrn. Museum of Practical Geology.

\section{Palmaster longimanos, Whidborne. (Page 204.)}

3. Wax impression from the mould of the upper surface of a small specimen, the arms of which are really longer than here visible, $\times 4$. Top Orchard Quarry. My Collection.

Codonaster conicus, n. sp. (Page 214.)

4. Small specimen, showing the sutures, $\times 6$. 4a. Upper view showing the disc, the surface of which is partly destroyed, $\times 12$. Top Orchard Quarry. Woodwardian Museum.

\section{Pentremitidea Phildipsit, n. sp. (Page 212.)}

5. Mould of a specimen, showing two ambulacra and an interradius, $\times 10$. $5 a$. Wax impression of a portion of one of the ambulacra, showing the food-grooves and the plates, $\times 20$. Wrafton Lane. My Collection.

6. Cast of a radial plate with an ambulacra, $\times 3$. Ashford Strand. Barnstaple Athenæum. 

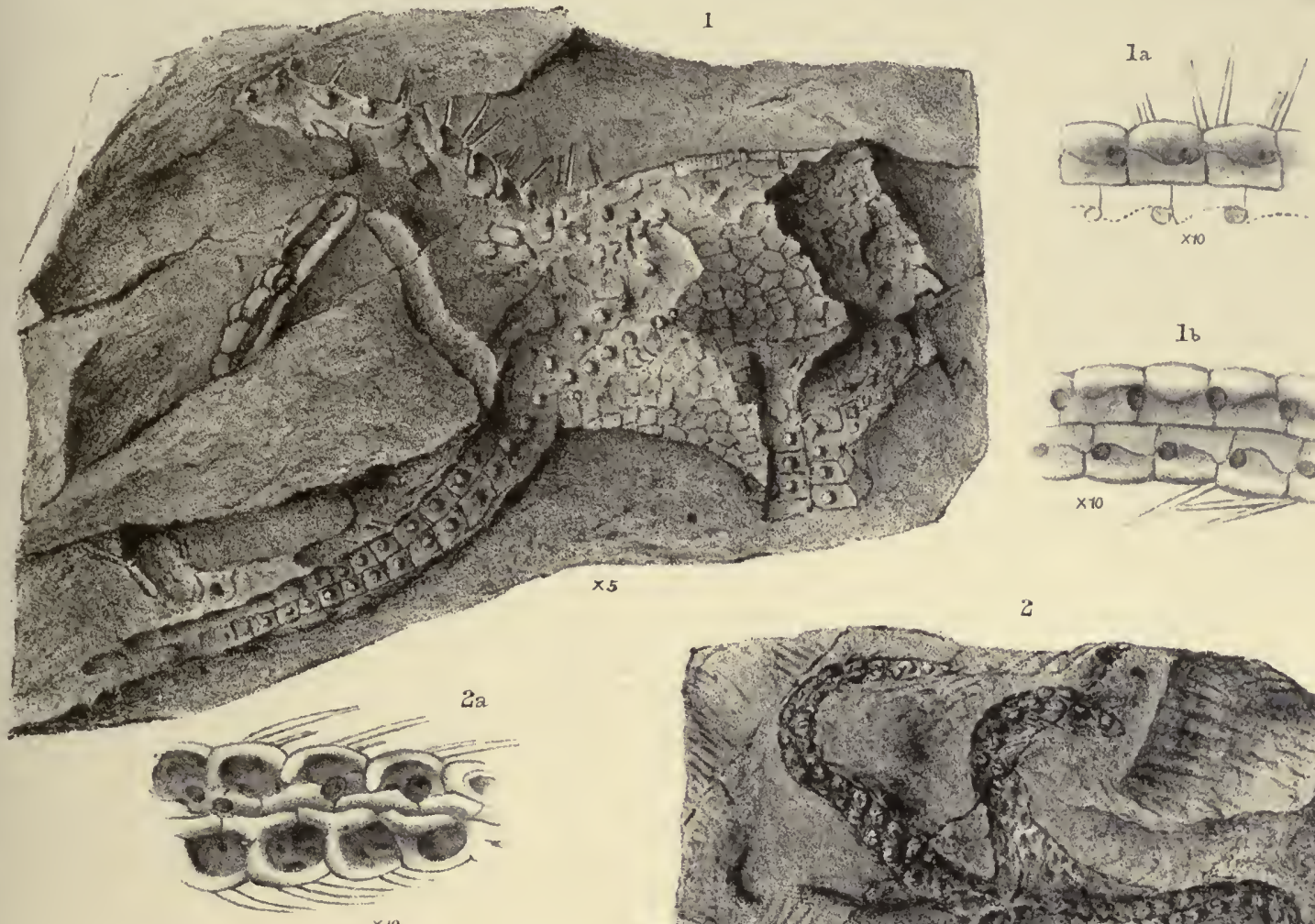

Ib

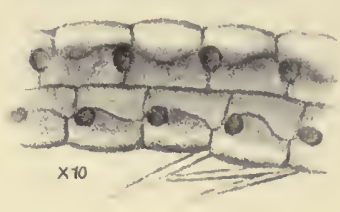

2

6
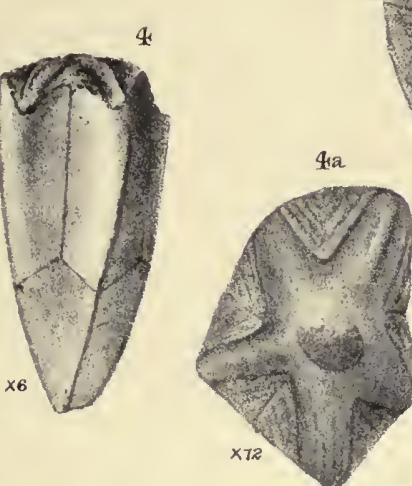

$x^{3} \frac{x}{2}$
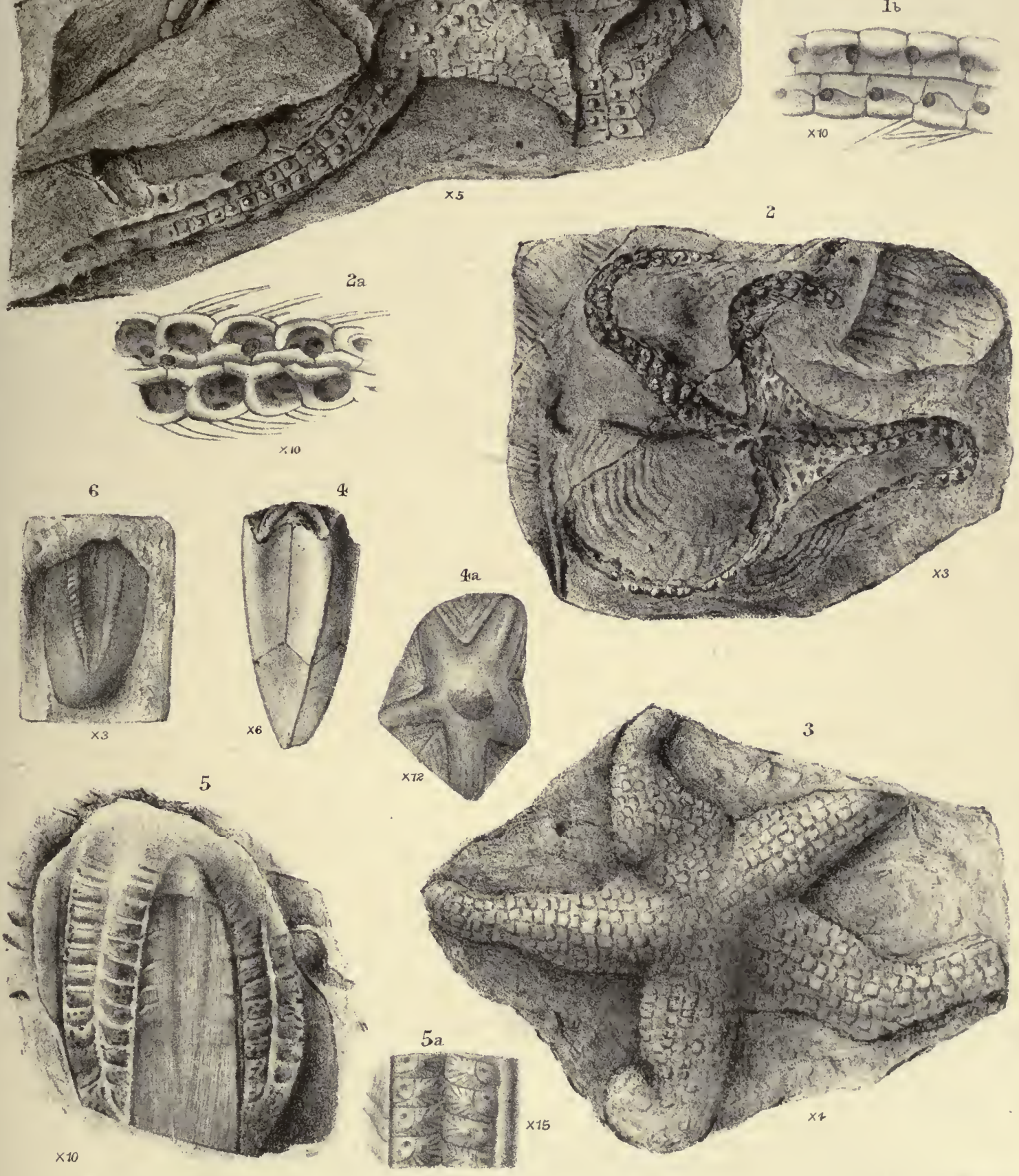


\section{PLATE XXX.}

Adelocrinus hystrix, Phillips. (Page 224.)

Fig.

1. Basal view of the wax impression of a mould of part of a dorsal cup, $\times 2$. Pilton. Porter Collection.

2. A single concave plate of another cup (possibly an anal plate?), $\times 4$. Pilton. Porter Collection.

3. Wax impression of part of another cup, having larger and more numerous tubercles, and being quadrate in horizontal section, $\times 2$. Bradford. Barnstaple Athenæum.

4. Wax impression from Phillips's type specimen, having few and small tubercles, $\times \frac{3}{2}$. Brushford. Museum of Practical Geology.

5. Specimen of a calix with arms attached, $\times 2$. Top Orchard. Barnstaple Athenæum.

6. The other side of the same animal, showing the arms, $\times 2.6 a$. Wax impression of a portion of one of the arms, showing the plates and pinnules, $\times 7$. Top Orchard. Barnstaple Athenæum.

7. Specimen, showing parts of five arms with their pinnules in situ, and part of the calix of the same or another animal, $\times \frac{3}{2} .7 a$. Wax impression of one of the arms, $\times 7$. Braunton. Museum of Practical Geology.

\section{Actinocrinus Porteri, Whidborne. (Page 220.)}

8. Gutta-percha cast of a specimen, $\times 2$. Barnstaple. Woodwardian Museum. 
PI ATE XXX
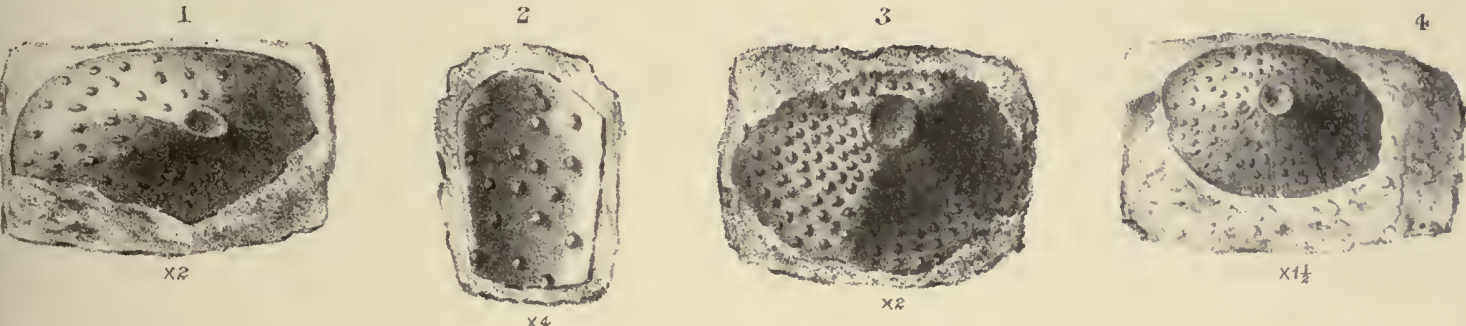

5

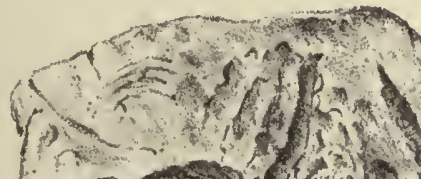

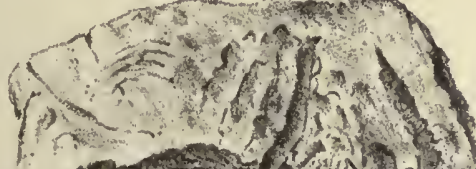

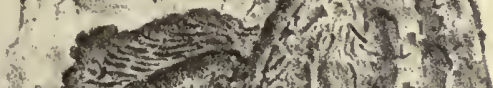

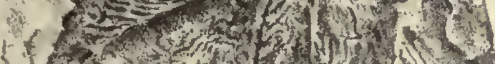

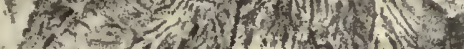

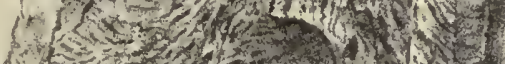

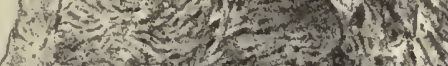

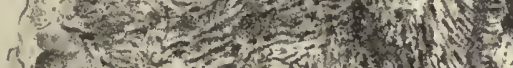

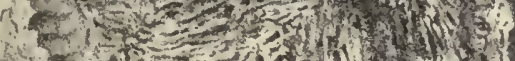

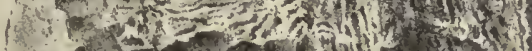

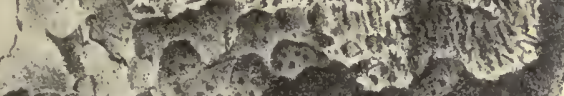

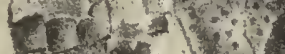
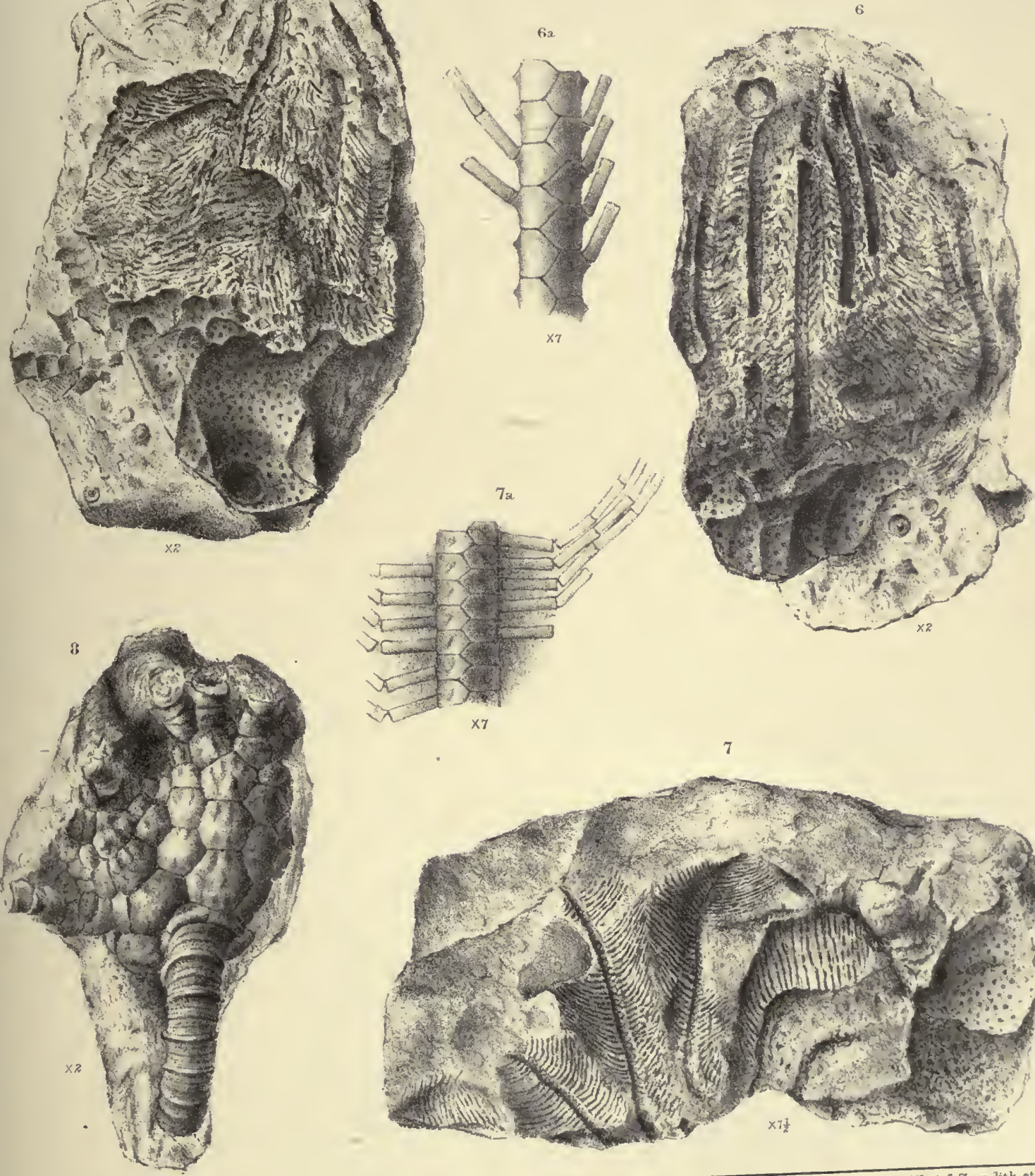

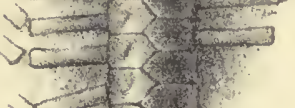

$$
\begin{aligned}
& x_{x-1}^{2}+x
\end{aligned}
$$

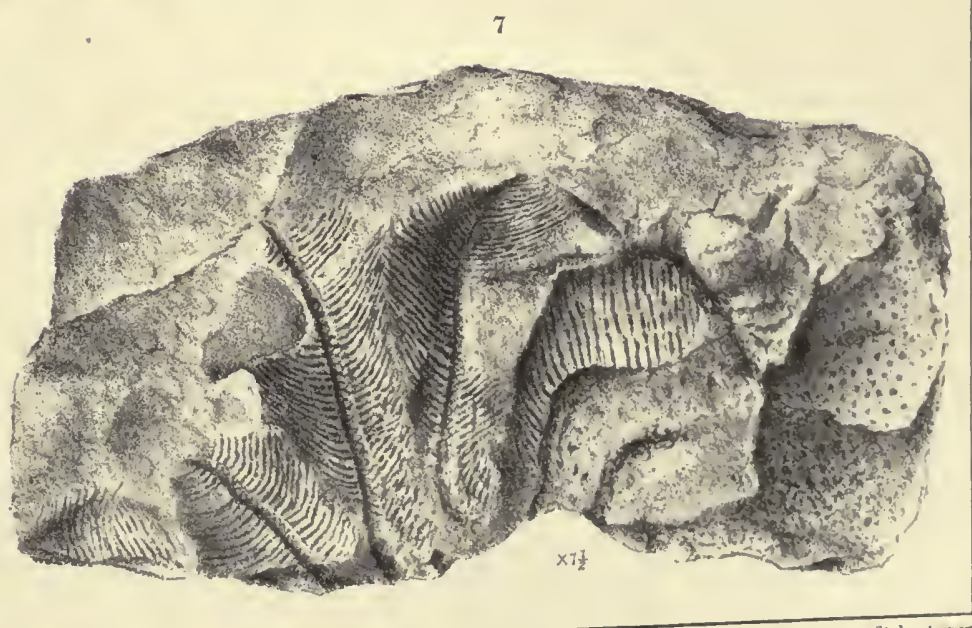

Geo. West \& Sors jith. et um 




\section{PLATE XXXI.}

\section{Adtinocrinus Porteri, Whidborne. (Page 220.)}

Fra.

1. Mould of part of a calix with arms and pinnules, nat. size. $1 a$, wax cast of a portion of one of the arms, showing a curious triple branching, $\times 2$. North Devon. Museum of Practical Geology.

2. Mould of the opposite side of the same animal as fig. 1, showing part of the dome. North Devon. Museum of Practical Geology.

\section{RHodocrinus? sp. (Page 217.)}

3. Specimen showing a defective dorsal cup with armlets and long arms clothed with fine pinnules, nat. size. $3 a$, a plate of the cup, $\times 7$. $3 b$, a portion of an arm, showing the arrangement of the plates, $\times 10.3 \mathrm{c}$, impression of the inner surface of one of the pinnules, $\times 25.3 d$, portion of the outer surface of one of the arms, $\times 5$. North Devon. Museum of Practical Geology.

\section{Scaphiocrinus? Piumifer, n. sp. (Page 228.)}

4. Gutta-percha cast of a specimen, nat. size. $4 a$, anal side of the dorsal cup, $\times 6.4 b$, one of the arms, $\times 5.4 c$, impression of one of the pinnules, $\times 25$. Barnstaple. Woodwardian Museum.

Actinocrinus Porteri, Whidborne. (Page 220.)

5. Part of the dorsal cup and arms of a large specimen, nat. size. Braunton. Museum of Practical Geology. 
P1.ATE XXXI
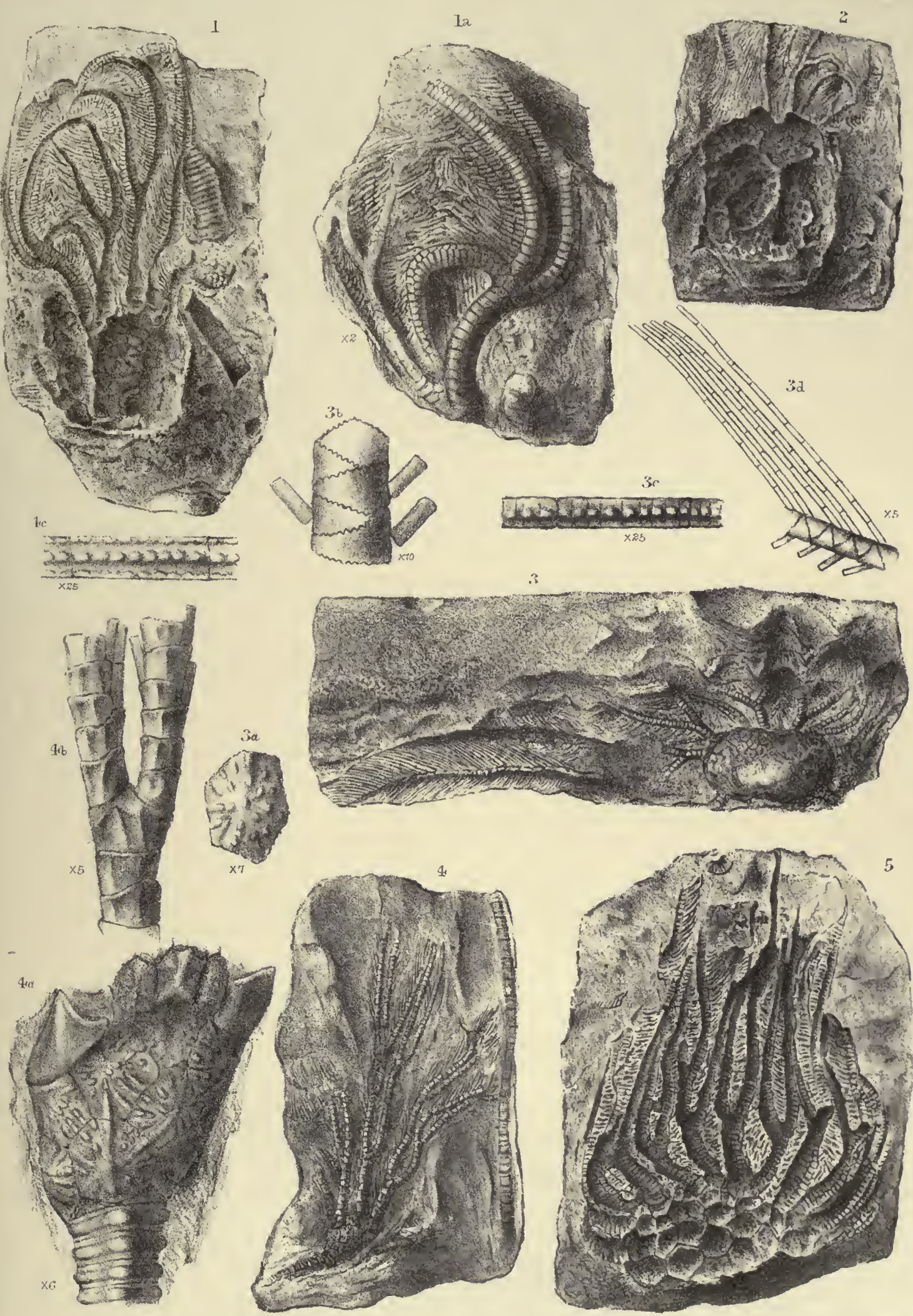




\section{PLATE XXXII.}

Actinocrinus Porteri, Whidborne. (Page 220.)

Fig.

1. Specimen, containing the opposite side of the dorsal cup figured on Pl. XXXI, fig. 5, together with the stems of several other individuals. Braunton. Museum of Practical Geology.

ACtinocrinus? Ba'theri, Whidborne. (Page 222.)

2. Mould of the dome and inner side of the arms, $\times \frac{3}{2}$. $2 a$, wax cast of part of the dome, showing some of the plates, $\times 3$. $2 b$, three plates, $\times 10$. Braunton. Museum of Practical Geology.

3. Mould of the dorsal cup of the same individual, $\times \frac{3}{2}$. $3 a$, wax cast of the dorsal cup, slightly restored, $\times 3.3 b$, lateral view, $\times 3$. Braunton. Museum of Practical Geology. 


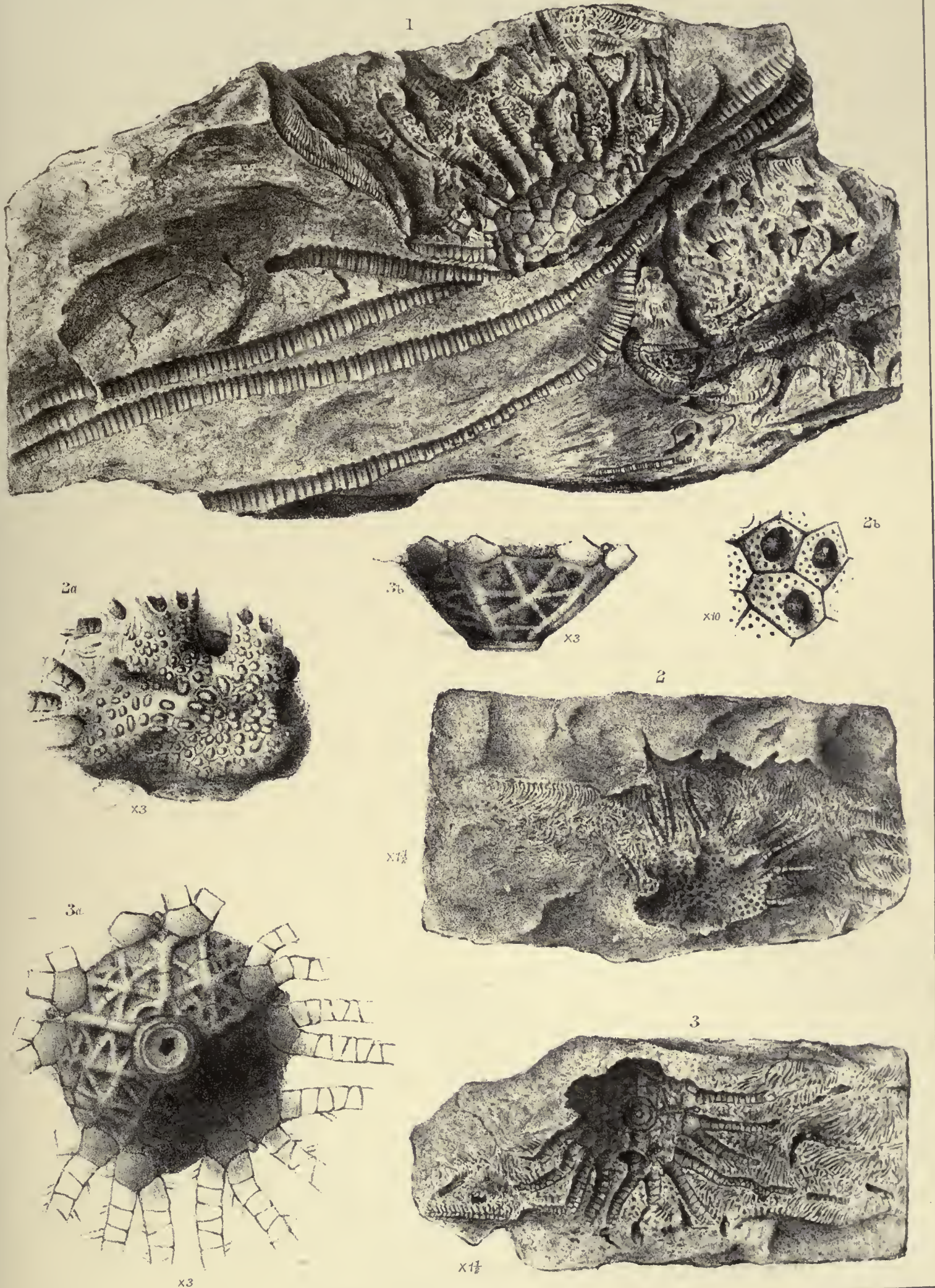






\section{PLATE XXXIII.}

\section{Soaphiocrinus? Plumifer, n. sp. (Page 228.)}

Fig.

1. Gutta-percha cast of a large specimen, in which the plates of the dorsal cup are broken away, $\times 2$. Barnstaple. Woodwardian Museum.

Taxocrinus macrodactylus, Phillips. (Page 215.)

2. The only remaining specimen of Phillips's types of this species known, nat. size. Pilton. Museum of Practical Geology.

3. Another specimen, showing the bifurcations of the arms, $\times \frac{3}{2}$. $3 a$, wax cast of the inner side of one of the arms, $\times 3$. North Devon. Museum of Practical Geology.

4. Another specimen, being a cast in the upper part and a mould in the lower, nat. size. $4 a$, wax cast of the top of the stem and lower part of the dorsal cup, restored above the dotted line from the arms seen in the specimen, $\times$ 2. North Devon. Museum of Practical Geology. 


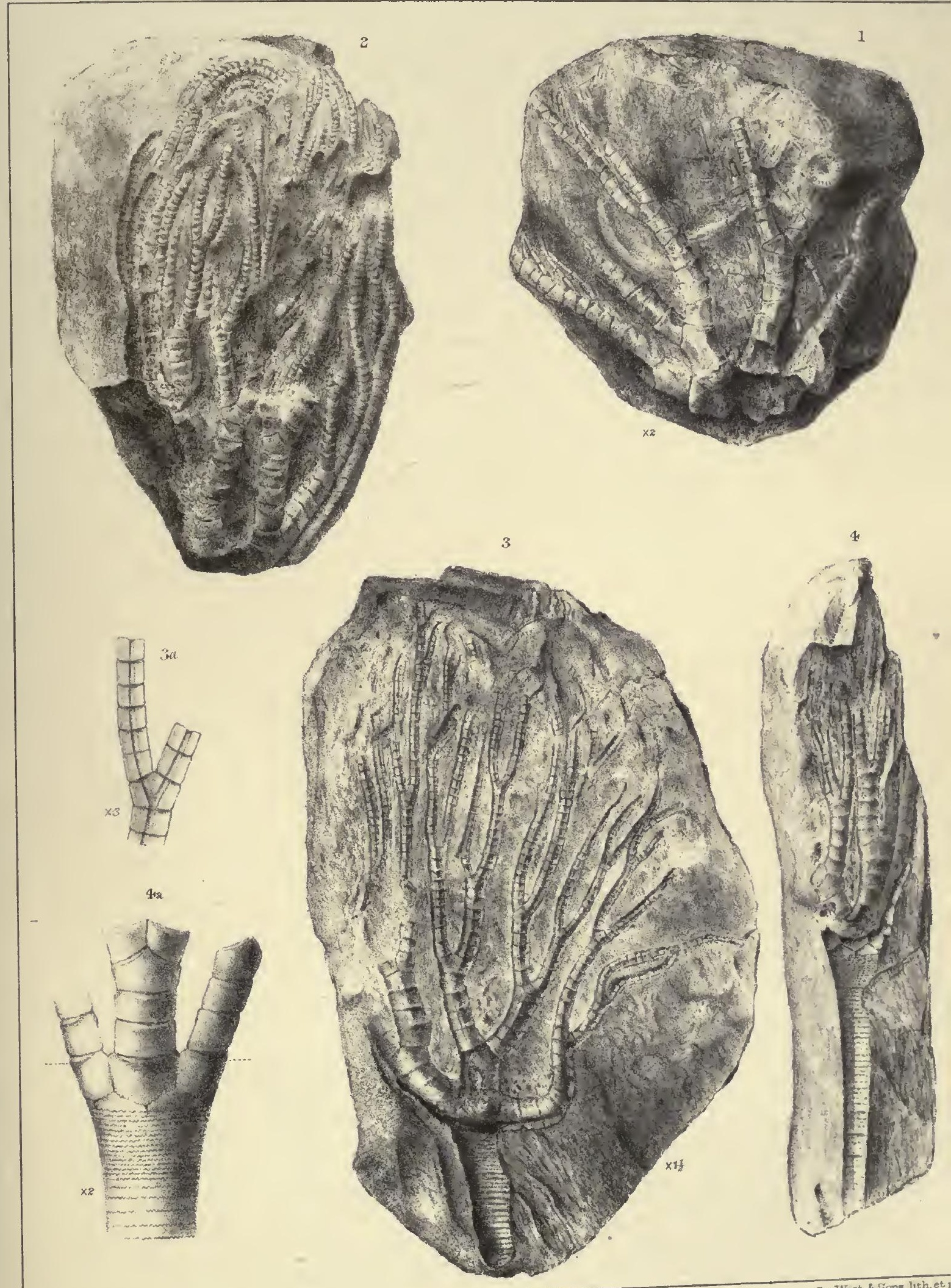





\section{PLATE XXXIV.}

\section{Taxocrinus stulíus, Whidborne. (Page 216.)}

Fig.

1. Wax cast of a specimen, showing the top of the stem, the dorsal cup, and the beginnings of the arms, one of which has three primibrachs and five and six secundibrachs respectively, $\times 3$. (The little plates seen between the arms have been drawn too regularly, and are probably not pinnules, but scattered plates from the infolded extremities of the arms.) Pilton. Porter Collection.

2. Mould of the opposite side of the same individual, $\times 2.2 a$, wax cast, showing anal plates, $\times 3$. Pilton. Porter Collection.

3. Another specimen, showing the character of the stem, $\times 2$. Pilton. Porter Collection.

\section{SP. INDET.}

4. Terminal portion of an arm with stout short pinnules, $\times 4$. $4 a$, portion, $\times$ 10. Pilton. Porter Collection.

\section{Mariocrinus ? sp. (Page 219.)}

5. Doubtful specimen, showing the arms and a few plates of the dorsal cup, $\times 2$. Braunton. Barnstaple Athenæum.

\section{Poteriocrindos Bardmensis, Whidborne. (Page 227.)}

6. Gutta-percha cast of a specimen showing the plates of the dorsal cup, the first primibrachs axillary, and nine secundibrachs in one of the arms, $\times 2$. Barnstaple. Woodwardian Museum.

\section{Scaphiocrinus !' inordinatus? n. sp. (Page 230.)}

7. Mould of a specimen, very doubtfully referred to this species, $\times \frac{3}{2}$. Braunton. Museum of Practical Geology.

\section{Scaphiockindes? sp. (Page 231.)}

8. Mould of a specimen, showing the very shallow dorsal cup and the large primibrachs, $\times \frac{3}{2}$. $8 a$, portion of an arm, showing the pinuules, $\times 5$. Braunton. Museum of Practical Geology. 

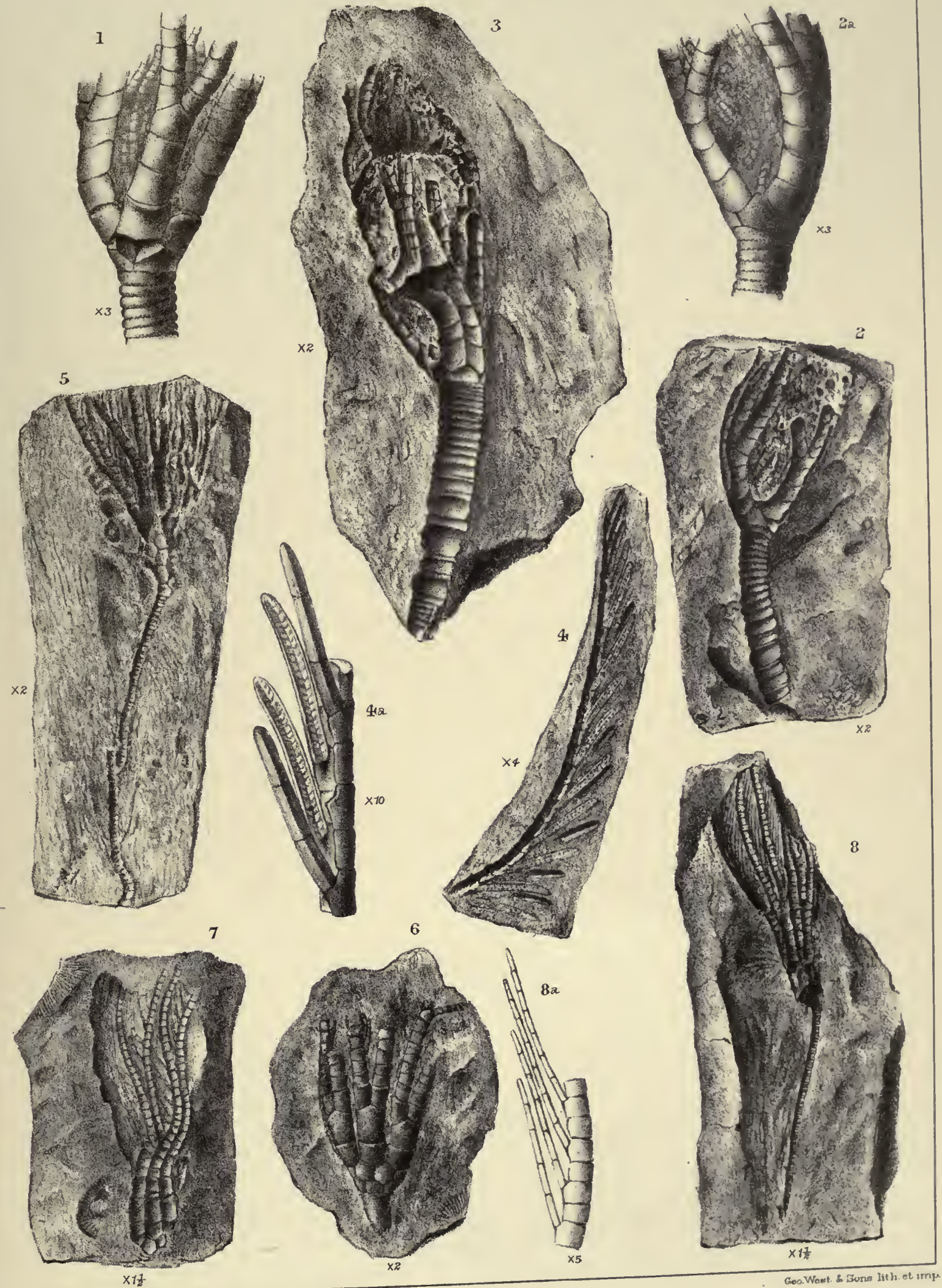



\section{PLATE XXXV.}

\section{Puteriocrinus tensus, Whidborne. (Page 226.)}

FIa.

1. Gutta-percha cast of a specimen, showing the dorsal cup (much injured), the branching of the arms, and fragments of the anal tube, $\times 2$. (The plates between the cup and the first bifurcations of the arms have been restored in this figure, and perhaps incorrectly.) $1 a$, portion of one of the arms, $\times 5$. Barnstaple. Woodwardian Museum.

2. Another gutta-percha cast, taken subsequently from the same specimen, showing the opposite side of the dorsal cup, $\times 2$. Barnstaple. Woodwardian Museum.

\section{Poteriocrindos Barumensis, Whidborne. (Page 227.)}

3. Specimen, showing the plates of the dorsal cup and the arms, and having a curious deformity in the stem, $\times 2$. Top Orchard Quarry. Woodwardian Museum.

Poteriocrinus, sp. (Page 228.)

4. A large detached ventral sac, nat. size. Braunton. Museum of Practical Geology.

5. Specimen, showing one arm, part of the ventral sac, and some plates of the dorsal cup, nat. size. $5 a$, portion of the arm, showing an armlet which appears to bear pinnules, $\times 5$. Barnstaple. Woodwardian Museum.

Scaphiocrinus ? inordinatus, n. sp. (Page 230.)

6. Specimen, showing the dorsal cup and arms, $\times 2.6 a$, portion of one of the arms, showing the pinnules, $\times 7$. Barnstaple. Woodwardian Museum. 
PLATE XXXV.

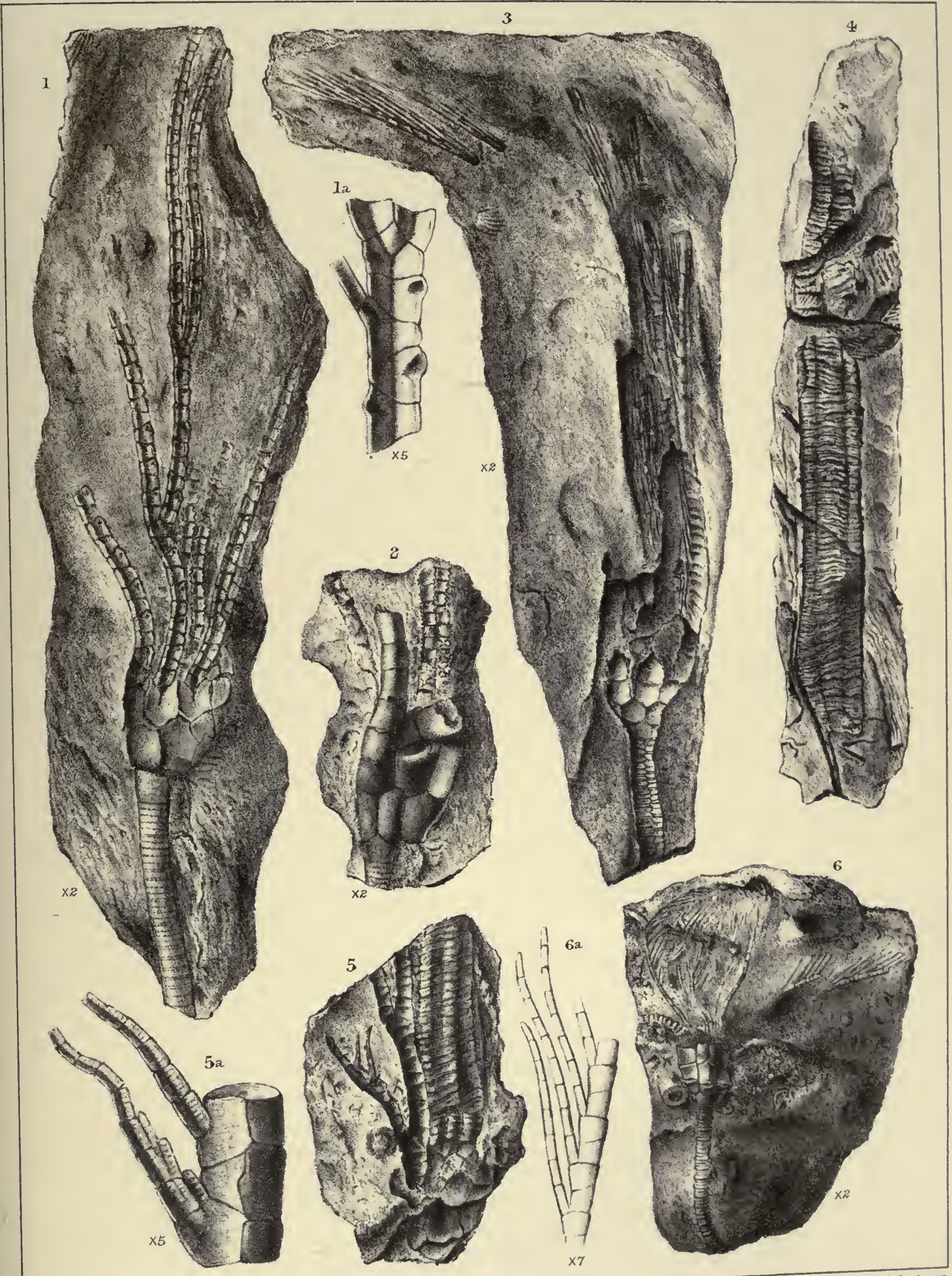


$-1-$ 



\section{PLATE XXXVI.}

FiG.

Scaphiocrinus? plumifer, n. sp. (Page 228.)

1. Mould of a specimen in rough preservation, $\times \frac{3}{2}$. $\quad 1 a$, wax cast of the dorsal cup, showing the plates, the surface-ornamentation of which appears to have been obliterated, $\times 3$. Braunton. Museum of Practical Geology.

\section{Sortalocrinus? stadiudadtrlus, Whidborne, sp. (Page 233.)}

2. Wax cast of a specimen, showing the anal side of the dorsal cup and the ventral sac, nat. size (see PI. XXXVII, fig. 14). $2 a$, dorsal cup, $\times 4$. Braunton. Barnstaple Athenæum.

3. Specimen in which the dorsal cup is obliterated, but the expanded arms and pinnules are seen, $\times 2$. $3 a$, gutta-percha cast of the central parts, $\times 4$. Barustaple. Woodwardian Museum.

4. Wax cast of a specimen, showing the anal side of the dorsal cup and the beginning of the ventral sac, the plates of the stem being obliterated, $\times 3$. Pilton. Porter Collection.

5. Wax cast of part of a dorsal cup with closed arms, $\times 4$. Roborough. Barnstaple Athenæum.

6. Mould, showing the plates of the dorsal cup, the first and second primibrachs and the beginning of the arms, $\times 2$. Pilton. Porter Collection.

8. Mould of a smaller specimen, $\times 3$. Roborough. Barnstaple Athenæum.

SP. INDE'T.

7. Terminal portion of an arm, $\times 2.7 a$, portion showing the pinnules, $\times 6$. Pilton. Porter Collection.

\section{Poteriocrinds, sp. (Page 228.)}

9. Mould of a defective dorsal cup, with portions of two arms and the upper part of the stem, nat. size. $9 a$, portion of one of the arms, showing the pinnules, $\times 3$. Braunton Down. Museum of Practical Geology. 


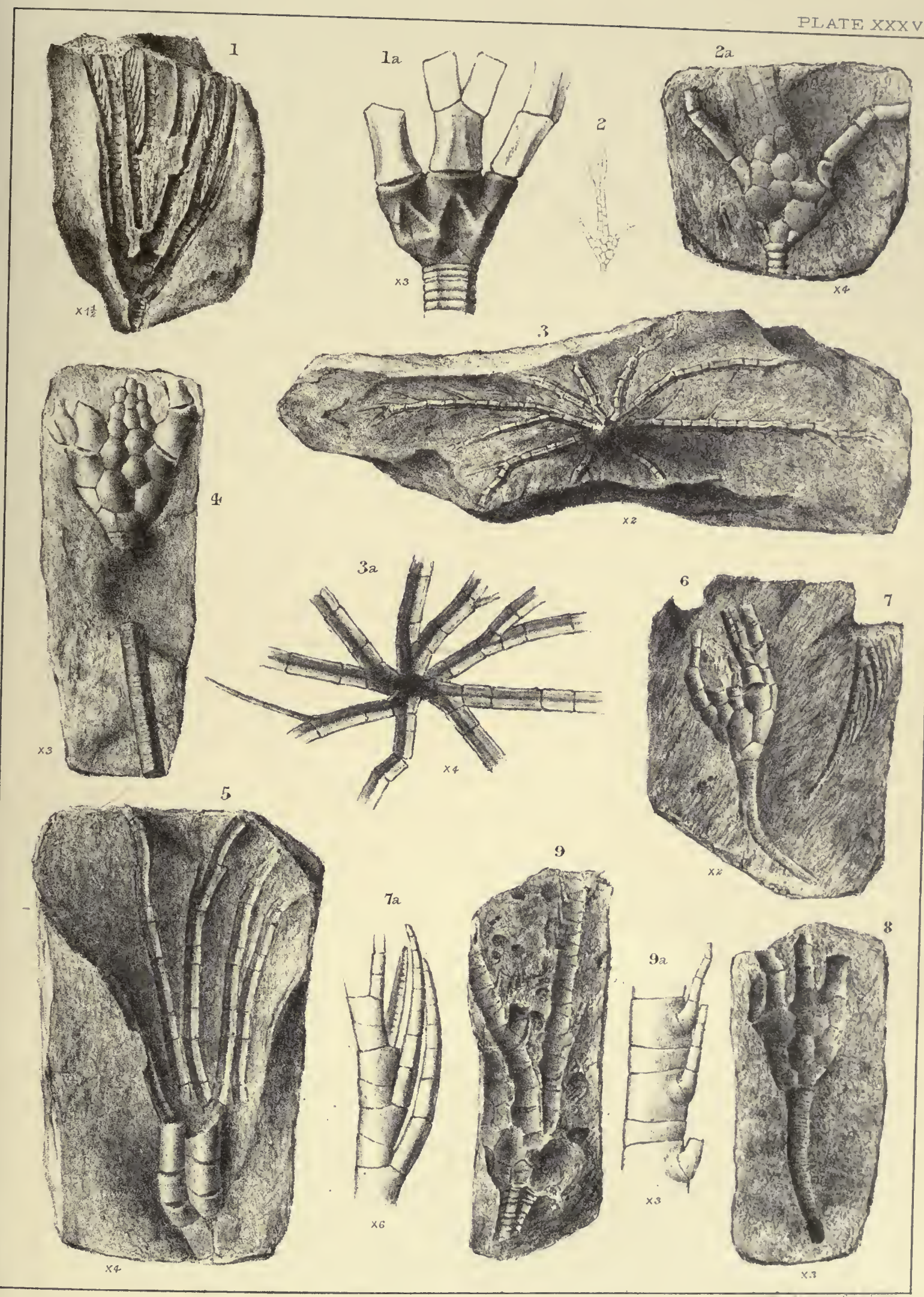

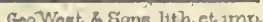





\section{PLATE XXXVII.}

Fig.

\section{Connulites devonianos, Whidborne. (Page 198.)}

1. Small specimen, $\times 8$. Pilton. Porter Collection.

2. Small recurved specimen, $\times 8$. Roborough. Porter Collection.

3. Larger specimen with irregular annulations, $\times 2$. Pilton. Porter Collection.

\section{Medusaster parvus, n. sp. (Page 205.)}

4. Mould of a specimen, showing the disc, the buccal plates, and the sixteen arms, $\times$ 9. North-east of Harford Landkey. Hamling Collection.

\section{Megistockinus? sp. (Page 218.)}

5. Cast of a dorsal cup, showing primibrachs, secundibrachs, interradials, and interambulacrals, $\times 6$. Barnstaple. Woodwardian Museum.

\section{Mariocrinus? mundus, n. sp. (Page 219.)}

6. Specimen, showing the mould of the stem and the dorsal cup, and the cast of the arms, $\times 3$. Croyde Rocks. My Collection.

7. Mould of the other side of the same dorsal cup, $\times 3$. Croyde Rocks. My Collection.

\section{Platychinus? anguliferus, n. sp. (Page 223.)}

8. Mould of a specimen, showing two radials, some smaller plates, and the beginnings of the arms, $\times 2$. Saunton Hotel. Mr. Coomara Swamy's Collection.

9. Detached radial, $\times 3$. Roborough. Porter Collection.

10. Wax cast of a radial with stronger ornamentation, $\times 3$. Pilton. Porter Collection.

11. Wax cast of another radial, $\times 3$. Roborough. Porter Collection.

12. Mould of a detached columnar, probably belonging to this species, $\times 3$. Vicarage Lane, Pilton. Barnstaple Athenæum.

\section{Scaphiocrinus? salebrosus, n. sp. (Page 232.)}

13. Mould of a dorsal cup, showing the tumid plates, $\times 2$. Pilton. Porter Collection.

\section{Soxtalocrinus stadiodactylus, Whidborne, sp. (Page 233.)}

14. The same specimen as figured on Pl. XXXVI, fig. 2, showing the dorsal cup, the ventral sac, and the arms: $\times 2$. Braunton. Barnstaple Athenæum. 
PLATEXXXVII
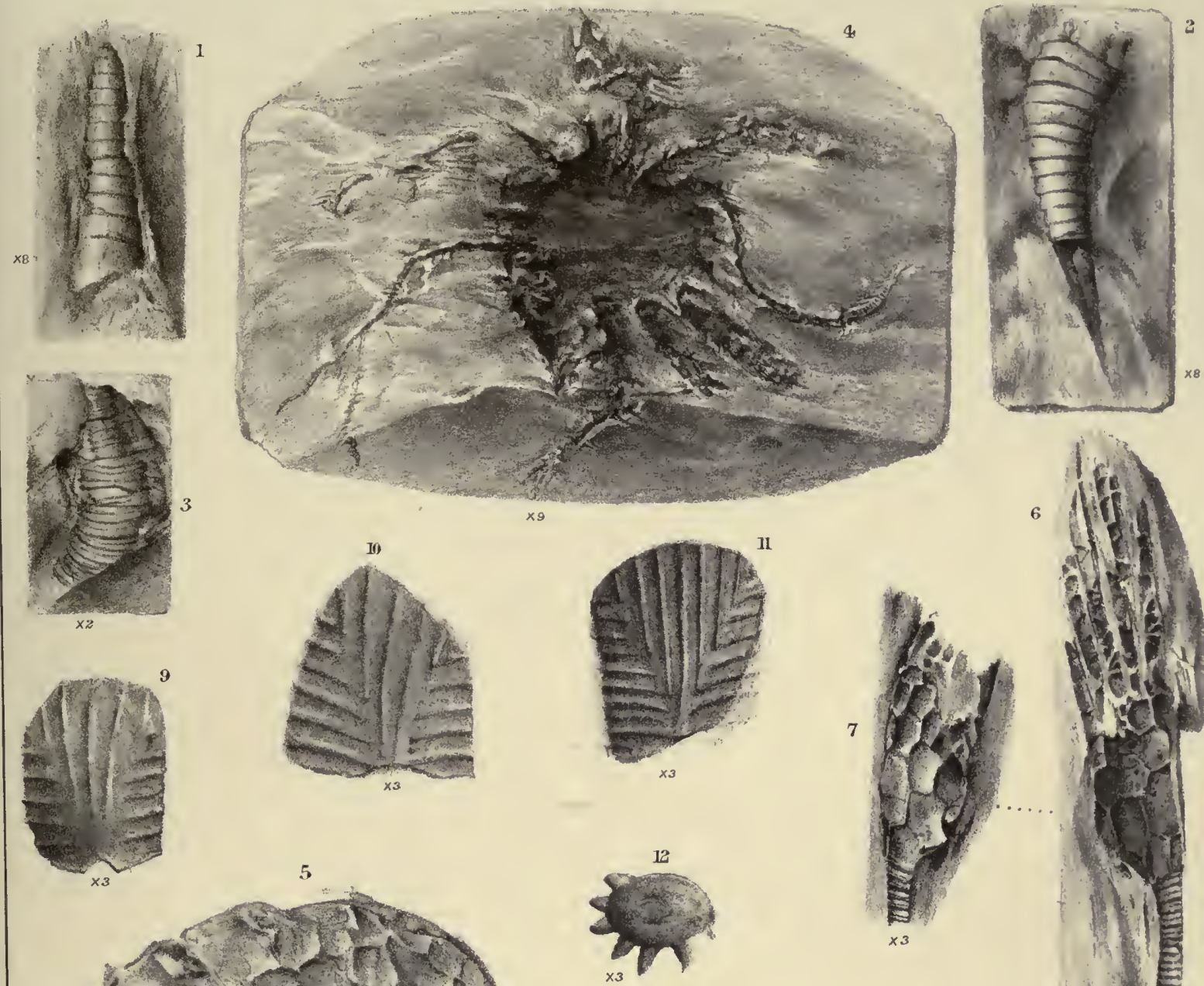

5
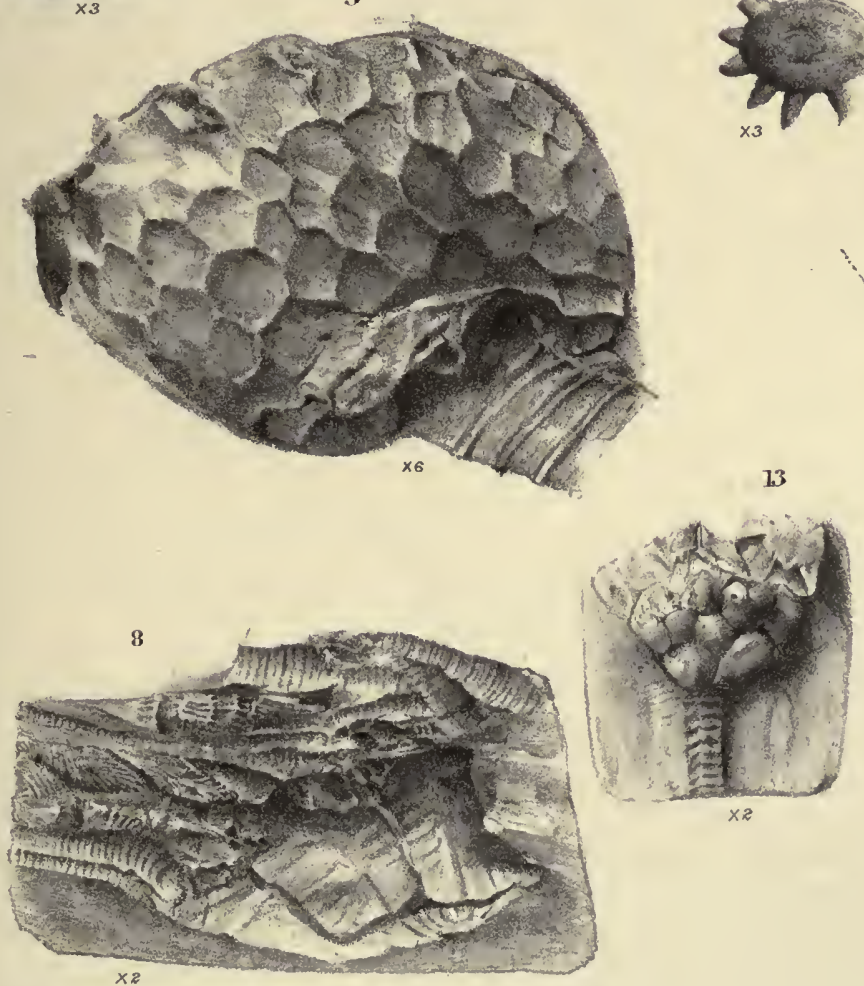<smiles>C=CC(C)(C)C=[IH]</smiles>
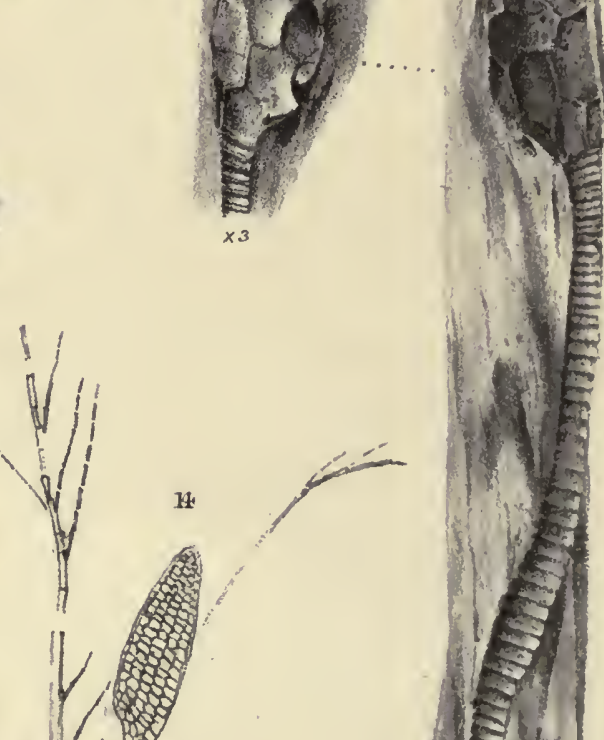




\section{PLATE XXXVIII.}

Poteriocrinus tensus, Whidborne. (Page 226.)

Fia.

1. Specimen, showing the cast of the dorsal cup, the expanded arms (in which no bifurcations are visible), and the exceedingly long slight pinnules, $\times 2$. Saunton Hotel. Partridge Collection.

\section{SCAPHIOCRINUS? PLUMifer, n. sp. (Page 228.)}

2. Gutta-percha cast of a specimen showing the dorsal cup and the closed arms, $\times 2$. Barnstaple. Woodwardian Museum.

\section{Scaphiocrinus transcisus, n. sp. (Page 230.)}

3. Wax cast of a specimen, showing some plates of the anal side of the dorsal cup and the beginning of the ventral sac, nat. size. Poleshill. Porter Collection.

\section{Scaphiocrinds? inordinatus, n. sp. (Page 230.)}

4. Cast of a flattened specimen, showing the arrangement of the plates of the dorsal cup, including the anal plate in the basal ring, and (in four of the arms) the two primibrachs, $\times 2$. Upcott Arch. My Collection.

\section{Scytalocrinus arachnoideus, n. sp. (Page 235.)}

5. Gutta-percha cast of a specimen, showing the upper part of the stem, the plates of the dorsal cup, the ventral sac, and part of the arms, $\times 2$. Barnstaple. Woodwardian Museum.

6. Gutta-percha cast of another specimen, showing the arms, $\times 2$. Barnstaple. Woodwardian Museum.

\section{Ceriocrinus? n. sp. (Page 236.)}

7. Gutta-percha cast of a specimen, showing the mode of branching of the arms, their short cuneate plates, and the pinnules, $\times 2$. Barnstaple. Woodwardian Museum. 
PLATE XXXVIII
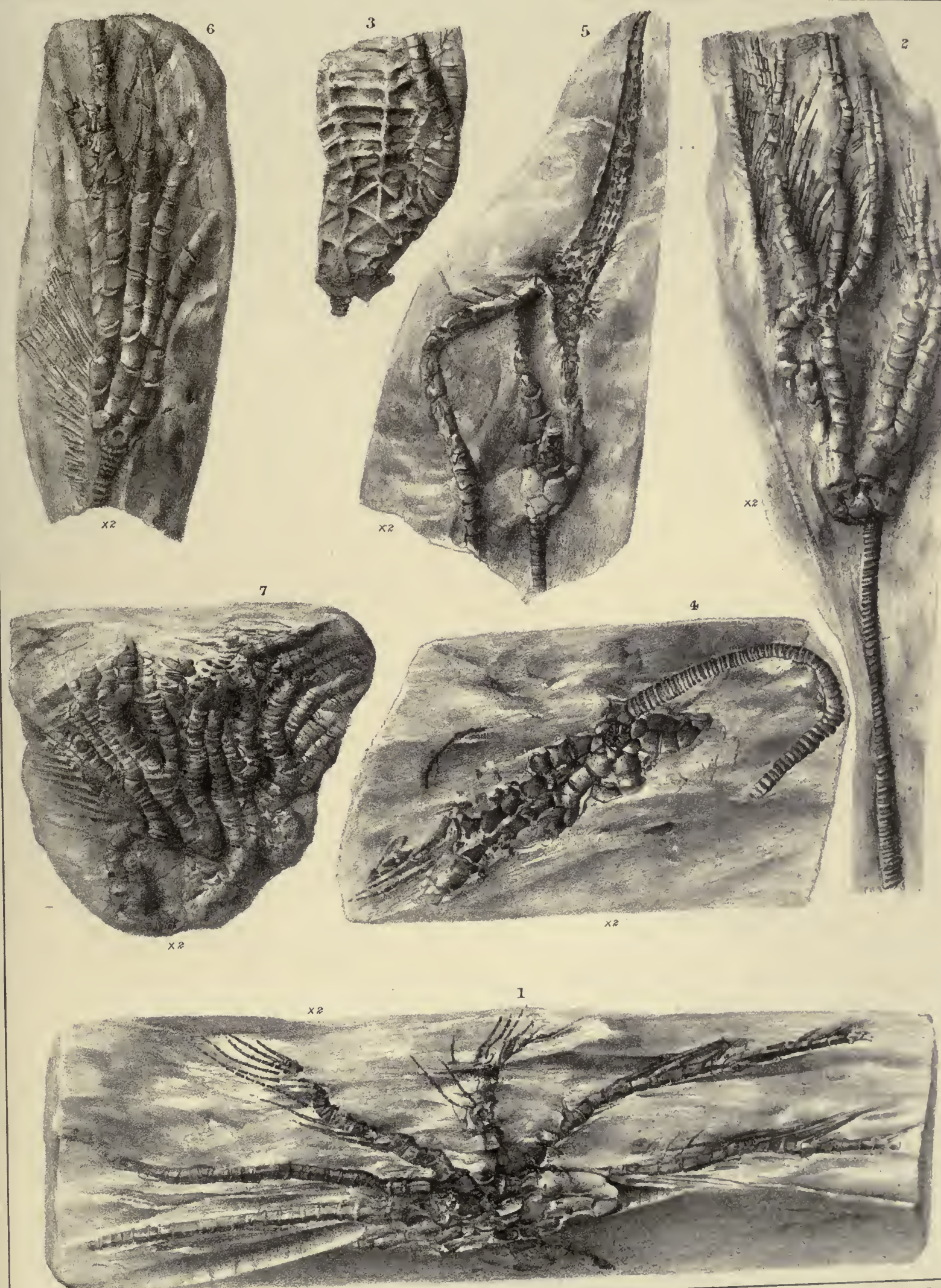



